VERÔNICA CAVALCANTE DA FONSECA

\title{
O DIREITO DE GREVE DOS SERVIDORES PÚBLICOS COMO DIREITO HUMANO FUNDAMENTAL
}

\author{
Dissertação de MESTRAdo
}

Orientador: Professor Dr. EnOQue Ribeiro dos SANTOS

FACULDADE DE DIREITO DA USP

SÃO PAULO

2009 


\section{O DIREITO DE GREVE DOS SERVIDORES PÚBLICOS COMO DIREITO HUMANO FUNDAMENTAL}

Dissertação de Mestrado apresentada ao Departamento de Direito do Trabalho e da Seguridade Social da Faculdade de Direito da Universidade de São Paulo como exigência parcial para a obtenção do título de Mestre em Direito do Trabalho e da Seguridade Social

Orientador: Professor Dr. Enoque Ribeiro dos Santos

FACULDADE DE DIREITO DA USP

SÃO PAULO

2009 


\section{SUMÁRIO}

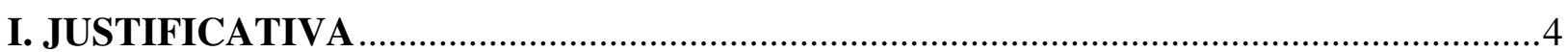

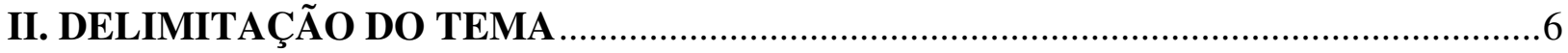

III. MÉTODOS E TÉCNICAS DE PESQUISA .........................................................

1. O DIREITO DE GREVE NA ESTRUTURA DO DIREITO COLETIVO DO

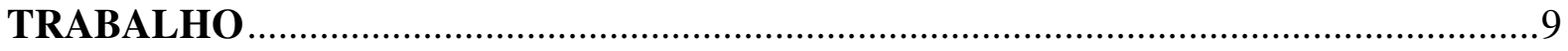

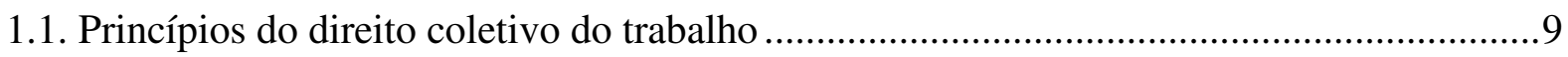

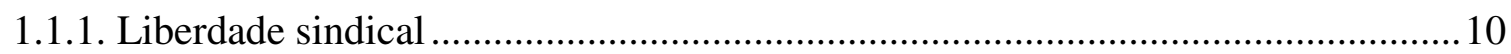

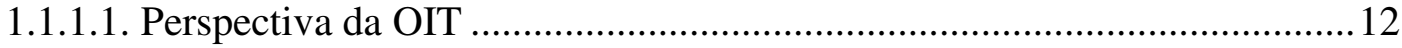

1.1.1.2. Liberdade sindical: suas variadas faces .................................................. 13

1.1.1.3. Garantias da liberdade sindical ......................................................... 14

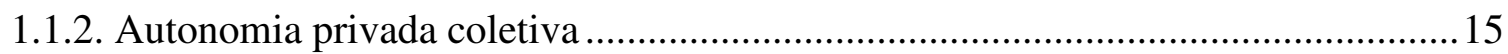

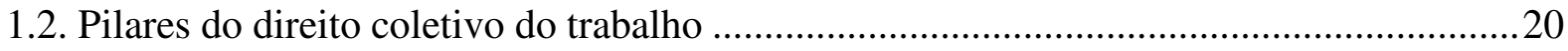

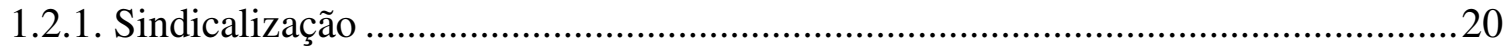

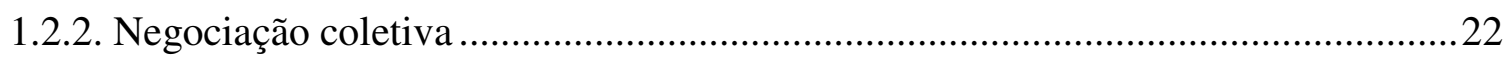

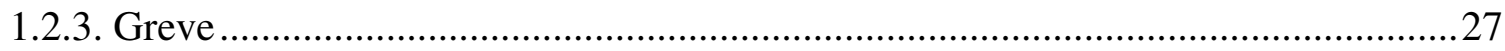

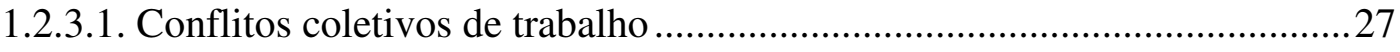

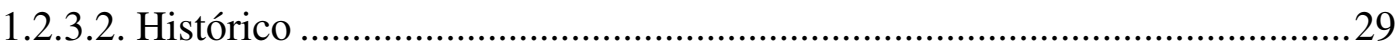

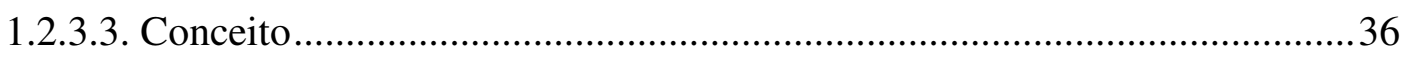

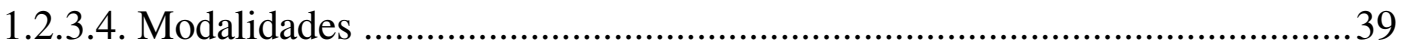

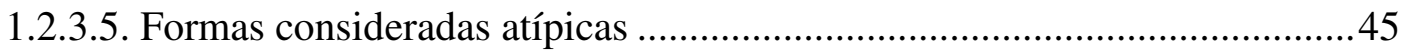

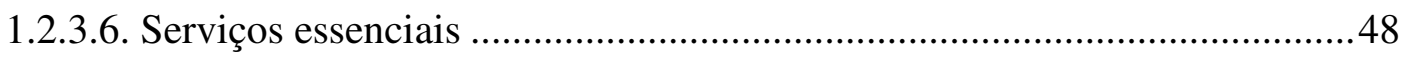

2. DIREITO DE GREVE DOS SERVIDORES PÚBLICOS ...........................................49

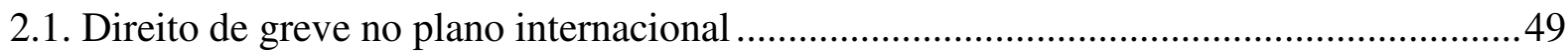

2.1.1. A Organização Internacional do Trabalho ...........................................................50

2.1.2. Perspectiva da OIT em relação ao direito de greve dos servidores públicos ...........51

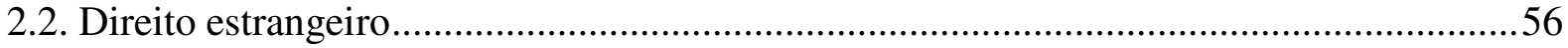

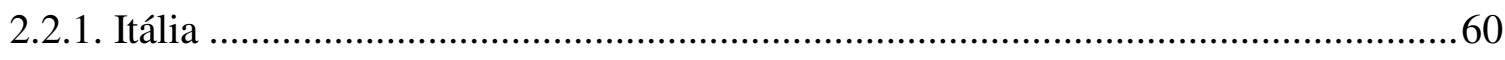

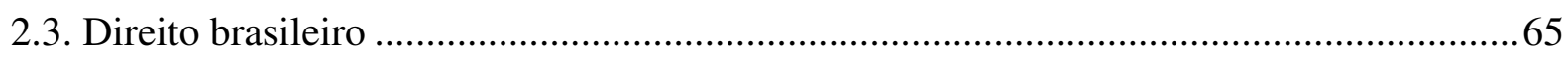

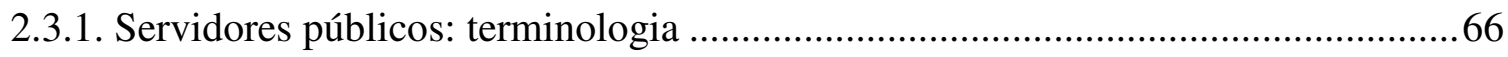

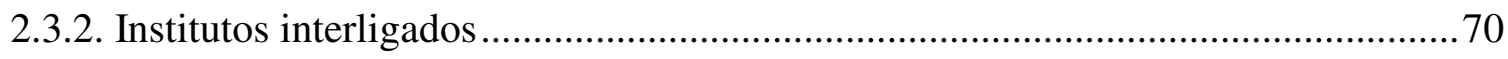

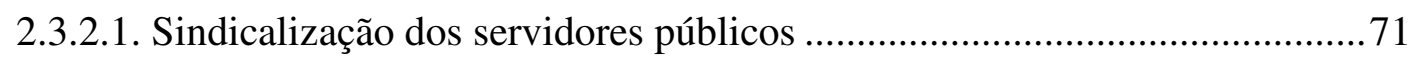

2.3.2.2. Negociação coletiva dos servidores públicos ........................................ 74 
2.3.3. Histórico

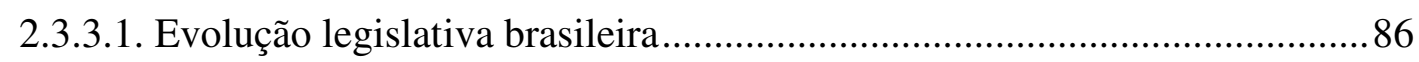

2.3.4. Investigação sobre as causas das greves no serviço público......................................92

2.3.5. O debate acerca da greve dos servidores públicos ................................................94

2.3.6. Posições doutrinárias e jurisprudências em relação ao direito de greve dos servidores públicos na Constituição de 1988 …………………………………........98

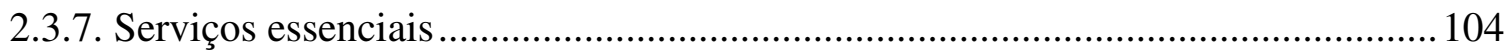

\section{DIREITO DE GREVE DOS SERVIDORES PÚBLICOS NA ÓTICA DOS}

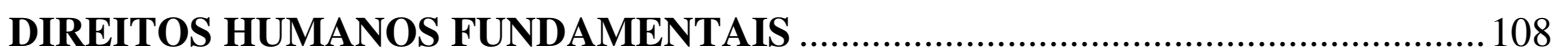

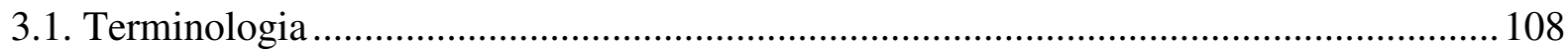

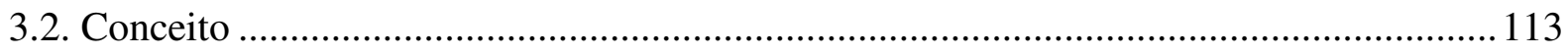

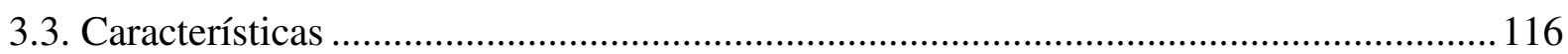

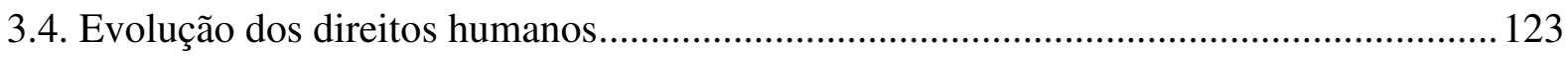

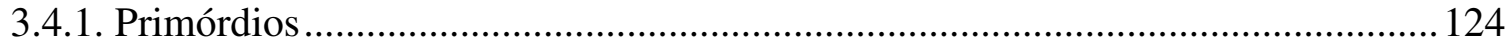

3.4.2. Influência jusnaturalista na composição dos direitos humanos ...............................125

3.4.3. Dos primeiros documentos à constitucionalização ............................................... 125

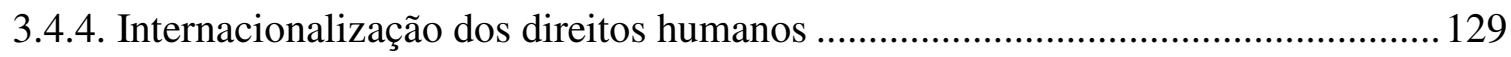

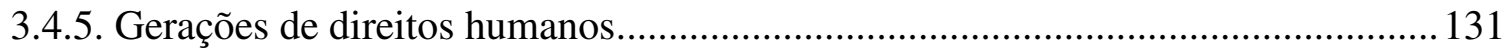

3.4.5.1. Direitos de primeira geração.................................................................... 133

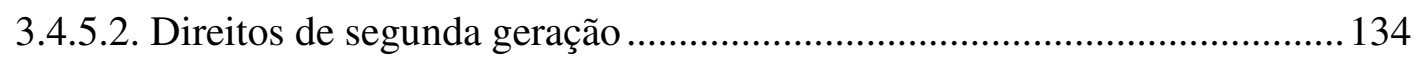

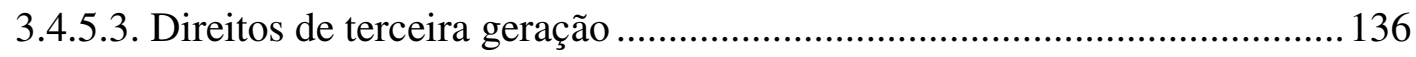

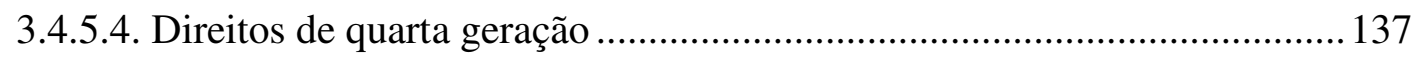

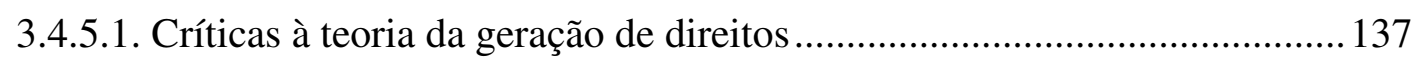

3.5. O exercício do direito de greve como efetivação dos direitos humanos...........................139

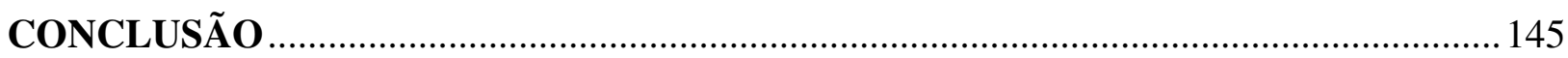

RESUMO

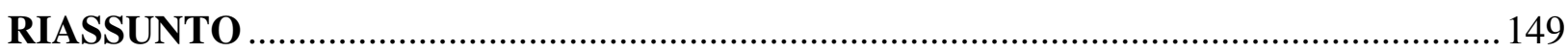

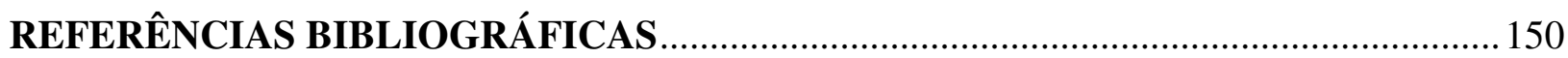




\section{JUSTIFICATIVA}

O direito de greve está garantido na Constituição, no entanto, o seu exercício enfrenta dificuldades. São diversos os fatores envolvidos, que vão da conjuntura econômica e social até o entendimento doutrinário e jurisprudencial a respeito da greve. Este último fator, afeta, principalmente, os servidores públicos, uma vez que o exercício desse direito vem sendo negado sob inúmeros argumentos e, recentemente, houve uma mudança da posição do STF sobre o tema. Quanto àquele, se levarmos em consideração que, diante da crise econômica, da escassez de postos de trabalho e do exército de desempregados, o maior contingente de greves ocorre, justamente, no setor público.

Apesar das divergências, a realidade nos apresenta um grande contingente de greves no setor público. Elas continuam acontecendo, cada vez em maior número, e se alongam por meses, afligindo a todos enquanto usuários dos serviços públicos, pois a greve é, antes de qualquer coisa, um fato social. Sendo assim, independentemente do tratamento jurídico que lhe for atribuído elas continuarão a existir, a não ser que os conflitos desapareçam, o que é improvável. Sendo assim, é importante que seja dado um tratamento adequado ao direito de greve dos servidores públicos, para que ele possa efetivamente existir. Os posicionamentos que inviabilizavam desde logo esse direito, em nada contribuem para alcançar o que eles mesmos defendem, que é a preservação do interesse público.

O direito estrangeiro, sobretudo, o dos países que integram o sistema romanogermânico, tem um entendimento diverso sobre o tema a ser estudado. Um olhar sob o ângulo comparativo poderá trazer uma luz sobre a questão do direito de greve no serviço público.

O estudo relativo ao direito de greve no setor público encontra-se em uma posição de intersecção entre o direito coletivo do trabalho e o direito administrativo. Embora o primeiro englobe a maior parte deste espaço, há uma necessidade de se levar em consideração aspectos do segundo. Existem princípios que regem o direito administrativo e que interferem, por meio de suas especificidades e da necessidade de mecanismos próprios, no direito de greve no setor público. Contudo, isso não impede o exercício desse direito fundamental. Desta forma, exige-se, por parte dos estudiosos do direito, uma maior atenção sobre esse tema, para que essa situação limítrofe não gere um vazio, uma lacuna. 
Por tudo o que foi exposto acima, podemos dizer que um estudo apurado sobre o direito de greve dos servidores públicos se faz necessário. É um direito constitucionalmente assegurado, e, sobretudo, um direito humano fundamental. 


\section{DELIMITAÇÃO DO TEMA}

A presente pesquisa dedica-se ao estudo do direito de greve dos servidores públicos. Ela procurará demonstrar, por meio de argumentos jurídicos, além da própria legislação, que o direito de greve no serviço público é uma espécie do gênero direitos humanos. Sendo assim, para que estes últimos sejam respeitados há que se garantir a efetivação daquele.

No primeiro capítulo, será analisado o direito de greve dentro da estrutura do direito coletivo do trabalho. Para isso, serão apresentados os seus princípios básicos, liberdade sindical e autonomia privada coletiva, que formam o seu alicerce, sobre o qual estão erguidas, tal como pilastras, a sindicalização, a negociação coletiva e a greve, que completam a sustentação do edifício direito coletivo do trabalho. A greve será analisada, neste capítulo, sob o ponto de vista do conflito, inerente ao convívio em sociedade. Também será investigado se a doutrina tem restringido esse direito por meio da construção de um conceito limitativo, considerando algumas modalidades atípicas e, portanto, estranhas ao seu conceito, de forma a eliminar o acolhimento jurídico da dinâmica própria do fenômeno greve.

No segundo capítulo, o fenômeno da greve dos servidores públicos será estudado no plano internacional, principalmente, sob a perspectiva da Organização Internacional do Trabalho. Para isso, serão analisados a sua produção normativa e os pareceres do Comitê de Liberdade Sindical e da Comissão de Peritos. O direito de greve dos servidores públicos também será analisado nos ordenamentos estrangeiros, em especial, o caso da Itália. No ordenamento pátrio, será feita uma análise dos institutos interligados ao direito de greve dos servidores públicos - a sindicalização e a negociação coletiva -, da sua evolução histórica no Brasil e, ainda, a forma como a doutrina e a jurisprudência interpretam os artigos referentes ao tema na Constituição Federal de 1988. Além de uma investigação acerca da discussão entre interesse público e interesse privado, inerente à questão da greve dos servidores públicos. Estudar-se-á também a greve em serviços essenciais.

No terceiro capítulo, serão apresentados os fundamentos e as características dos direitos humanos, assim como o seu processo de evolução ao longo da história, que deu origem às várias dimensões de direitos. Além disso, será estudada a relação entre o exercício do direito de greve dos servidores públicos como efetivação dos direitos 
humanos, bem como o regime político que mais favorece a efetivação desse direito e, por conseguinte, a concretização dos direitos humanos fundamentais. 


\section{MÉTODOS E TÉCNICAS DE PESQUISA}

Os métodos de abordagem que serão utilizados no presente trabalho são: indutivo, dedutivo, analítico sintético e dialético.

Os métodos de procedimento a serem empregados são: dogmática jurídica e direito comparado. O primeiro se apóia no tripé doutrina, legislação e jurisprudência. O segundo, no confronto entre os ordenamentos jurídicos brasileiro, internacional e o de outros países do sistema romano-germânico quanto à matéria objeto de estudo.

Quanto às técnicas de pesquisa, serão utilizadas a consulta de fontes primárias (Constituição, leis ordinárias, normas internacionais etc) e a consulta de fontes secundárias (pesquisa bibliográfica). 


\section{O DIREITO DE GREVE NA ESTRUTURA DO DIREITO COLETIVO DO TRABALHO}

\subsection{Princípios do direito coletivo do trabalho}

O direito coletivo do trabalho, embora não seja um ramo autônomo do Direito, apresenta princípios básicos que formam a sua base estrutural. Para Maurício Godinho Delgado os princípios "são proposições gerais inferidas da cultura e ordenamento jurídicos que conformam a criação, revelação, interpretação e aplicação do direito". ${ }^{\prime}$

Este mesmo autor enumera os princípios especiais do direito coletivo do trabalho em três grupos. O primeiro deles reúne os princípios assecuratórios da existência do ser coletivo obreiro, que são a liberdade associativa e sindical e a autonomia sindical. O segundo grupo, por sua vez, concentra os princípios regentes das relações entre os seres coletivos trabalhistas, como o princípio da interveniência sindical na normatização coletiva, o da equivalência dos contratantes coletivos, o da lealdade e transparência nas negociações coletivas. O terceiro grupo, finalmente, apresenta os princípios regentes das relações entre normas coletivas negociadas e normas estatais, que são o princípio da

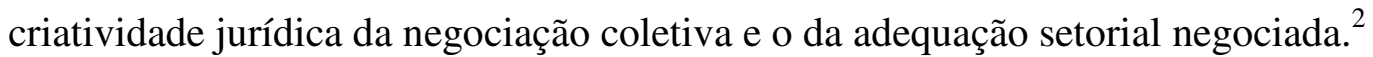

Oscar Ermida Uriarte afirma que, no plano dogmático do direito coletivo do trabalho, a existência do conflito serve como demonstração do caráter pluralista, democrático e livre da sociedade, que "se expressa na chamada triangularidade, isto é, em sua constituição baseada em três pilares fundamentais: autonomia sindical, autonomia coletiva e autotutela. No mesmo sentido, embora com terminologia diferente, o Comitê de Liberdade Sindical e a Comissão de Peritos em Aplicação de Convenções da OIT vêm afirmando repetidamente que a liberdade sindical, em sentido amplo, inclui a negociação coletiva e a greve". 3

O direito de greve, portanto, não pode ser considerado de forma isolada, pois integra uma estrutura complexa que inclui a necessidade de plena liberdade sindical, a existência de autonomia privada coletiva, expressa por meio da negociação coletiva. A

\footnotetext{
${ }^{1}$ DELGADO, Maurício Godinho. Princípios de direito individual e coletivo do trabalho. São Paulo: LTr, 2001. p. 16.

${ }^{3}$ ERMIDA URIARTE, Oscar. A flexibilização da greve. Trad. Edilson Alkmin. São Paulo: LTr, 2000. p. 10.
} 
liberdade sindical e a autonomia privada coletiva interferem de forma direta também na organização sindical e na negociação coletiva. Em razão disso, a despeito de qualquer rol de princípios do direito coletivo do trabalho, julgamos essencial, para a melhor compreensão do fenômeno da greve, sobretudo da greve dos servidores públicos, analisar mais detidamente dois princípios fundamentais do direito coletivo do trabalho: a liberdade sindical e a autonomia privada coletiva.

A liberdade sindical ${ }^{4}$ é um direito fundamental da pessoa humana, além disso, sustenta a estabilidade das instituições democráticas dos países. De acordo com Amauri Mascaro Nascimento, "uma democracia é adulta quando tem condições de preservar a liberdade sindical, o princípio maior da teoria da organização sindical, fruto de longa evolução das idéias e das estruturas sociais e políticas, cujas origens remotas são encontradas nas corporações de ofício medievais". 5

A autonomia privada coletiva, por sua vez, é a manifestação de um poder atribuído aos particulares para criar normas jurídicas. ${ }^{6}$ É uma normatividade que surge espontaneamente na sociedade, chamada de Wolksrecht pelos alemães, cuja natureza é móvel e variável e sua observância decorre do consenso e não da imposição. ${ }^{7}$ Fortalece-se, portanto, a democracia, uma vez que o exercício da autonomia privada coletiva possibilita a participação de corpos intermediários, dando voz ao cidadão no processo decisório. ${ }^{8}$

\subsubsection{Liberdade sindical}

O desejo de liberdade é tão antigo quanto a própria civilização. ${ }^{9}$ Desde os primórdios o homem luta por liberdade nas mais variadas questões que envolvem tanto suas ações como o seu pensamento, assim como, a manifestação deste. Em razão disso, a liberdade é um sentimento perseguido pela humanidade e permeia todas as esferas da

\footnotetext{
${ }^{4}$ FRANCO FILHO, Georgenor de Sousa. Liberdade sindical e direito de greve no direito comparado: lineamentos, São Paulo: LTr, 1992. p. 69.

${ }^{5}$ NASCIMENTO, Amauri Mascaro. Compêndio de direito sindical. 3. ed. São Paulo: LTr, 2003. p. 37.

${ }^{6}$ SILVA, Walküre Lopes Ribeiro. Autonomia privada, ordem pública e flexibilização do direito do trabalho. In: MEDEIROS, Antonio Paulo Cachapuz de (Org.). Faculdade de Direito da PUCRS: o ensino jurídico no limiar do novo século. Porto Alegre: Edipucrs, 1997. p. 211.

${ }^{7}$ GEMIGNANI, Tereza Aparecida Asta. Autonomia privada coletiva e intervenção estatal. Revista do Tribunal Regional do Trabalho da $15^{a}$ Região, n. 12, p. 34, 2000.

${ }^{8}$ Id. Ibid., p. 35.

${ }^{9}$ DUNNING, Harold. Orígenes del convênio núm. 87 sobre liberdade sindical y derecho de sindicación. Revista Internacional del Trabajo, Genebra, v. 117, n. 2, p. 168, 1998.
} 
atuação humana. Ela foi uma das bandeiras da Revolução Francesa e está na essência de qualquer regime democrático. ${ }^{10}$

Por isso, como não poderia deixar de ser, o desejo de liberdade também está presente na vida sindical. Mais que um desejo, para o direito coletivo do trabalho, a liberdade é uma de suas premissas e consubstancia-se no princípio da liberdade sindical. Amauri Mascaro Nascimento afirma que, "a liberdade sindical, como princípio, não nasceu de uma regra jurídica. É fruto da luta, do movimento sindical, contra a opressão do Estado para conseguir o seu reconhecimento e autonomia perante o Poder Público."

Octavio Bueno Magano conceitua a liberdade sindical como "o direito dos trabalhadores e empregadores de não sofrerem interferências nem dos poderes públicos nem uns em relação aos outros, no processo de se organizarem, bem como o de promoverem interesses próprios ou dos grupos a que pertençam". ${ }^{12}$ Sobre a expressão “interesses próprios”, Montoya Melgar afirma que ela "é eloqüente na ordem ao completo abandono de ideologias integrativas, segundo as quais trabalhadores e patrões coincidem em interesses comuns - servindo-se para isto determinados instrumentos: meios negociais, como a convenção coletiva, e meios de pressão como a greve e o lock out". ${ }^{13}$

A expressão "liberdade sindical" tem, segundo Amauri Mascaro Nascimento, ${ }^{14}$ mais de uma acepção. Pode significar um critério de classificação dos sistemas sindicais; pode assumir um sentido coletivo, como liberdade de associação, de organização, de administração e de exercício de funções; ou, um sentido individual, como liberdade de filiação e, também, um sentido conceitual. De acordo com este último sentido, o que interessa são os seus valores, seu alcance, suas características, manifestações e garantias, "que devem ser estabelecidas, para que, como princípio, cumpra a sua função, preservadora ou retificadora dos desvios, da lei ou da autoridade pública”.

A liberdade sindical é espécie cujo gênero é a liberdade de associação e, tanto uma como a outra compõem as liberdades civis. Isso pode ser comprovado nos trabalhos

\footnotetext{
${ }^{10}$ SILVA, Walküre Lopes Ribeiro. Liberdade sindical no contexto dos direitos humanos: a experiência da OIT. Revista do Departamento de Direito do Trabalho e da Seguridade Social. Departamento de Direito do Trabalho e da Seguridade Social da Faculdade de Direito da USP, São Paulo, v. 1, n.1, p. 207, jan./jun. 2006.

${ }^{11}$ NASCIMENTO, Amauri Mascaro. op. cit., p. 140.

${ }^{12}$ MAGANO, Octavio Bueno. Direito coletivo do trabalho. 3. ed. São Paulo: LTr, 1993. p. 27.

${ }^{13}$ MONTOYA MELGAR, Alfredo. Derecho del trabajo. 19. Madrid: Tecnos, 1998. p. 126.

${ }^{14}$ NASCIMENTO, Amauri Mascaro. op. cit., p. 140.
} 
preparatórios para a adoção da Convenção n. 87 da Organização Internacional do Trabalho e em pronunciamentos da Comissão de Peritos. ${ }^{15}$

\subsubsection{Perspectiva da OIT}

O direito à livre sindicalização foi consagrado na Organização Internacional do Trabalho em 1948, com a Convenção n. 87, como princípio mundialmente reconhecido e constitui o desenvolvimento normativo do princípio da liberdade sindical. ${ }^{16}$ Tal reconhecimento em nível internacional foi acompanhado por uma evolução normativa variável em função do momento político e econômico de cada país e, também, pela postura do Estado diante das reivindicações dos trabalhadores e, principalmente, pela forma utilizada por ele para solucionar os conflitos de classes. ${ }^{17}$

Logo após a adoção pela Organização Internacional do Trabalho da Convenção n. 87 sobre liberdade sindical e a proteção do direito de sindicalização, outro acontecimento notável para a legislação internacional de direitos humanos foi a aprovação pelas Nações Unidas da Declaração Universal de Direitos Humanos. Este documento tem um interesse especial para a OIT, uma vez que proclama no seu parágrafo 4 do artigo XXIII que "todo homem tem direito a organizar sindicatos e a neles ingressar para a proteção de seus interesses". 18

Cabe ressaltar que o princípio da liberdade sindical já estava incorporado em três instrumentos normativos da OIT: na sua própria Constituição, na Parte XIII do Tratado de Versalles na versão original; na Declaração da Filadélfia, incorporada à Constituição desse organismo internacional e; finalmente, na Convenção n. 87 de $1948^{19}$. Este último documento, chamado por comodidade de convenção sobre liberdade sindical, trata não apenas do simples direito de filiar-se a um sindicato, seja ele de trabalhadores ou de empregadores. Ele também diz respeito ao direito das organizações de trabalhadores e

\footnotetext{
${ }^{15}$ SILVA, Walküre Lopes Ribeiro. Liberdade sindical no contexto dos direitos humanos: a experiência da OIT, cit., p. 208-209.

${ }^{16}$ POTOBSKY, Geraldo von. El Convenio num. 87, su impacto y la acción de la OIT. Revista Internacional del Trabajo, Genebra, v. 117, n. 2, p. 217, 1998.

${ }^{17}$ OLIVEIRA, Olga Maria Boschi Aguiar de. A universalidade do princípio da liberdade sindical. Seqüência, Florianópolis, ano 18, n. 34, p. 7, jul. 1997.

${ }^{18}$ RANGEL, Vicente Marotta. Direito e relações internacionais. 6. ed. São Paulo: Ed. Revista dos Tribunais, 2000. p. 650.

${ }^{19}$ SWEPSTON, Lee. Desarollo de las normas sobre derechos humanos y libertad sindical mediante el control de la OIT. Revista Internacional del Trabajo, Genebra, v. 117, n. 2, p. 190, 1998.
} 
empregadores de redigir seus próprios estatutos e regulamentos administrativos, assim como, ao direito de eleição de seus representantes, de formular seus programas de ação e o de filiar-se a federações nacionais ou internacionais. Todos esses direitos devem ser garantidos sem que haja qualquer forma de ingerência dos poderes públicos. Pode-se dizer que a Convenção n. 87 da OIT é, sobretudo, um importante instrumento para a proteção dos direitos civis e políticos, sendo assim, do direito à democracia. ${ }^{20}$

É importante observar que a Convenção n. 151 da Organização Internacional do Trabalho consagra a liberdade sindical também aos trabalhadores da administração pública, deixando a cargo da legislação nacional dos Estados a aplicação dos preceitos desta convenção aos servidores públicos de alto nível e das forças armadas e da polícia.

Também a Declaração da OIT sobre os Princípios e Direitos Fundamentais no Trabalho de 1998 estipulou que todos os seus membros, tenham ratificado ou não as respectivas convenções, assumem o compromisso em relação aos princípios expressos nestes instrumentos normativos. Esse compromisso que decorre tão somente da condição de membro da organização, acarreta na obrigação de respeitar, entre outros princípios e direitos fundamentais, a liberdade sindical.

\subsubsection{Liberdade sindical: suas variadas faces}

A liberdade sindical, para ser compreendida na sua plenitude, precisa ser observada sob os seus mais variados aspectos. Trata-se, portanto, de uma figura complexa e exige um cuidadoso olhar para que não seja esquecido nenhum de seus aspectos, sob pena de sacrifício da própria liberdade.

Vários são os autores que a apresentam sob essa forma multifacetada, como veremos a seguir.

Mozart Victor Russomano compara a liberdade sindical a uma figura triangular. ${ }^{21}$ Segundo o autor, a liberdade sindical "é formada, conceitualmente, de três partes distintas, que se tocam nas extremidades, dando-nos a idéia de um perfeito triângulo jurídico”. O

\footnotetext{
${ }^{20}$ DUNNING, Harold. op. cit., p. 167-168.

${ }^{21}$ RUSSOMANO, Mozart Victor. Princípios gerais de direito sindical. 2. ed. Rio de Janeiro: Forense, 2000. p. 65.
} 
autor completa a sua idéia afirmando que a liberdade sindical, para ser considerada plena, compõe-se da sindicalização livre, da autonomia sindical e da pluralidade sindical. ${ }^{22}$

Amauri Mascaro Nascimento apresenta a liberdade sindical sob múltiplas dimensões: a liberdade de associação, a liberdade de organização, a liberdade de filiação, a liberdade de administração e a liberdade de exercício de funções. ${ }^{23}$

Octavio Bueno Magano, ao conceituar a liberdade sindical, apresenta várias condições para a sua efetividade, entre elas: a não interferência externa, seja ela oriunda do Estado ou de organizações patronais; a liberdade de organização; a liberdade para a promoção de interesses. $^{24}$

Como pudemos verificar, a liberdade sindical é composta de múltiplas facetas que incluem um complexo de muitas liberdades: a liberdade de criação de sindicatos, sob os critérios organizativos previstos pelos próprios interessados; a liberdade de não pertencer ou de pertencer ao sindicato ou, ainda, de desligar-se dele no momento que considerar conveniente; a liberdade de organização interna do sindicato, compreendida, entre outras coisas, pela livre composição de seus órgãos internos, pela aprovação de seus estatutos, pela criação e filiação a entidades de nível superior; a liberdade de decisão sobre as eleições de seus dirigentes, tanto quanto a sua forma como quanto ao número deles; a liberdade de escolha das suas atribuições em meio ao interesse de seus representados.

É importante observar que todas essas facetas da liberdade sindical são interligadas e interdependentes, sendo assim, a verdadeira liberdade depende do respeito ao conjunto de todas elas. ${ }^{25}$

\subsubsection{Garantias da liberdade sindical}

A liberdade sindical vem sendo proclamada aos quatro ventos, no entanto, de nada adianta isso se não forem promovidas medidas efetivas para a sua proteção. Amauri Mascaro Nascimento observa que "não teria sentido declarar, formalmente, a garantia da

\footnotetext{
${ }^{22}$ RUSSOMANO, Mozart Victor. op. cit.. p. 66.

${ }^{23}$ NASCIMENTO, Amauri Mascaro. Direito sindical. São Paulo: Saraiva, 1989. p. 115.

${ }^{24}$ MAGANO, Octavio Bueno. op. cit., p. 27.

${ }^{25}$ SILVA, Walküre Lopes Ribeiro. Repressão penal dos atos anti-sindicais no direito brasileiro e italiano. Boletim do Centro de Estudos da Procuradoria Geral do Estado, Suplemento especial, São Paulo, v. 17, n. 5, p. 10, maio 1993.
} 
liberdade sindical sem assegurar meios jurídicos de proteção dessa liberdade, dos representantes sindicais e do sindicato como organização". ${ }^{26}$

A Organização Internacional do Trabalho tem um instrumento normativo a respeito da proteção da liberdade sindical. É a Convenção n. 98, sobre o direito sindical e a negociação coletiva, considerada complementar à Convenção n. 87, que trata, sobretudo, da liberdade sindical.

A Convenção n. 98 proclama duas garantias principais da liberdade sindical: a proteção contra atos de discriminação, visando os trabalhadores individualmente considerados, e a proteção contra atos de ingerência, dirigida às organizações de trabalhadores e de empregadores.

A mencionada convenção estabelece em seu artigo $1^{\circ}$ que os trabalhadores devem gozar de proteção adequada contra atos de discriminação, desde o momento da sua contratação e deve prolongar-se durante toda a vigência do contrato de trabalho. $\mathrm{O}$ artigo $2^{\circ}$ deste mesmo instrumento normativo trata dos comportamentos que representam atos de ingerência, entendidos como aqueles capazes de interferir na constituição, no funcionamento e na administração dos sindicatos, praticados por empregadores. ${ }^{27}$

A proteção contra atos anti-sindicais tem se configurado em normas internacionais, assim como, nas legislações nacionais, não somente na esfera trabalhista, como também na esfera penal. Segundo Walküre Lopes Ribeiro da Silva, "a única forma apropriada de garantir a liberdade sindical é declarar a nulidade do ato anti-sindical, restituindo as partes à situação anterior. Contudo, os atos violatórios da liberdade sindical foram capitulados como delitos na legislação penal de alguns países, num reconhecimento expresso da relevância social do direito de sindicalização, em seus múltiplos aspectos". ${ }^{28}$

\subsubsection{Autonomia privada coletiva}

O mundo dos fatos, devido à fluidez e à mudança constante da realidade, apresenta uma multiplicidade de situações e um ritmo de evolução que o mundo do direito não consegue acompanhar. Há situações em que a normatividade autônoma se mostra mais

\footnotetext{
${ }^{26}$ NASCIMENTO, Amauri Mascaro. Direito sindical, cit., p. 115.

${ }^{27}$ ORGANIZAÇÃO INTERNACIONAL DO TRABALHO. Convenção n. 98, OIT. Disponível em: $<$ http://www.ilo.org/ilolex/portug/docs/convdisp1.htm>. Acesso em 15 jan. 2009.

${ }^{28}$ SILVA, Walküre Lopes Ribeiro. Repressão penal dos atos anti-sindicais no direito brasileiro e italiano, cit., p. 10.
} 
adequada que a normatividade estatal, sobretudo, devido à celeridade do processo negocial frente ao processo legislativo. Isso ocorre, principalmente, nos conflitos de interesse de caráter privado e com maior possibilidade de se chegar a um acordo. Fato que não ocorre naqueles conflitos de interesse de natureza pública, cuja regulação deve ser feita mediante a presença estatal como forma de assegurar a efetividade da norma. No primeiro caso, o Estado deve agir de forma a não abafar a atuação da esfera privada. Deve atuar como garantidor do exercício da autonomia privada, balizando e fixando limites com base no interesse público de forma a impedir a lesão de direitos de terceiros e da coletividade.

O direito não precisa necessariamente ser criado pelo Estado, isso não é da sua essência. A regulação pode e deve ter participação da sociedade para a sua efetividade, pois a força desacompanhada de cooperação social não a garante plenamente. No entanto, a cooperação social, que surge mediante o exercício da negociação, tem mais efetividade na indução de comportamento.

Como assevera Walküre Lopes Ribeiro da Silva, "o direito do trabalho foi um espaço privilegiado para a manifestação da autonomia privada coletiva", sendo que diversos fatores contribuíram para a sua relevância como poder normativo nas relações coletivas de trabalho. ${ }^{29}$ A autora afirma que a expansão de autonomia privada coletiva é um fenômeno típico do século XX, porém ele teve a sua origem no século XVIII, durante a Primeira Revolução Industrial, num contexto liberal. Os trabalhadores viviam uma situação de extrema exploração, com jornadas de trabalho extenuantes, com salários aviltantes e em péssimas condições de saúde e de segurança. Além disso, o desemprego provocado pela substituição do trabalho humano pelas máquinas agrava ainda mais esse quadro. ${ }^{30}$

Como observa Segadas Vianna, "fatos políticos e sociais geraram crises que iriam, conseqüentemente, repercutir na situação dos trabalhadores, com redução dos salários e dispensas em massa. Na Inglaterra, na segunda década do século XIX, a terminação da guerra napoleônica provocava uma profunda depressão nas indústrias existentes ou fomentadas pelas exigências do conflito, com a brusca suspensão das encomendas nas fábricas de canhões, nas de pano, nas de artigos de couro e em todas as indústrias de ferro. Meio milhão de homens ficava ao desemprego, dentre os que estavam mobilizados nas forças armadas e nos serviços auxiliares; ao mesmo tempo, a adoção cada vez mais freqüente das máquinas a vapor, reduzia as possibilidades de obtenção de

${ }^{29}$ SILVA, Walküre Lopes Ribeiro. Autonomia privada, ordem pública e flexibilização do direito do trabalho, cit., p. 212.

${ }^{30}$ Id. Ibid., p. 214-216. 
trabalho e a revolução social começava a enfrentar suas primeiras crises, para as quais estava ainda totalmente desaparelhada. Os trabalhadores rurais incendiavam lavouras e, nas cidades, operários atribuíam seu desemprego à maquinaria usada e destruíam fábricas. Esse movimento chegou a ter uma denominação especial, 'ludismo'- pelo fato de em Leicestershire, um tal Ned Ludd, em um acesso de furor ter destruído os teares de uma fábrica". 31

Em meio a essa realidade terrível, os trabalhadores demonstraram de diversas maneiras o seu descontentamento e a sua revolta. Primeiramente, como demonstrado anteriormente, agiram de forma desordenada, por meio da destruição de máquinas e de instalações das indústrias. Logo depois, perceberam que agiam em vão, pois atacavam as máquinas, como se fossem elas a causa de seus males. ${ }^{32}$ Com o tempo passaram a se organizar em entidades clandestinas, uma vez que havia proibição legal para qualquer associação, e usavam as greves como meio de pressão, nem sempre bem sucedidas.

Neste contexto, o Estado viu-se obrigado a abandonar a sua posição liberal e a intervir nas relações de trabalho, aprovando leis protetoras do trabalhador. No entanto, esta nova postura do Estado não suprimiu a necessidade da autonomia privada coletiva, que garantiu a presença da negociação coletiva num momento em que não havia leis protetoras do trabalhador. O Estado não pode regular todas as particularidades das relações de trabalho em razão da rigidez e da lentidão do processo legislativo. Por isso, aquele espaço conquistado por meio da força pelos trabalhadores organizados coletivamente foi reconhecido pelo Estado e leis passaram ter o caráter de garantias mínimas alteráveis com o exercício da autonomia privada coletiva. ${ }^{33}$

O direito do trabalho emana de duas fontes distintas tanto quanto à natureza como em relação ao tipo de normas por meio das quais expressam seus preceitos. A coexistência delas ao longo da evolução desse ramo do direito apresenta-se como um dos seus traços característicos. Manuel Alonso Olea assevera que, “de um lado, há o Estado, com todos os órgãos e poderes que integram sua estrutura moderna, exteriorizando sua vontade normativa através das vias tradicionais (lei e jurisprudência, compreedendo-se nestas duas categorias gerais todas as espécies que a integram); de outro lado, os grupos profissionais

\footnotetext{
${ }^{31}$ VIANNA, José de Segadas. Direito coletivo do trabalho. São Paulo: LTr, 1972. p. 199.

${ }^{32}$ HUBERMAN, Leo. História da riqueza do homem. Trad. Waltensir Dutra. 21. ed.. Rio de Janeiro: Guanabara Koogan, 1986. p. 185-187.

${ }^{33}$ SILVA, Walküre Lopes Ribeiro. Autonomia privada, ordem pública e flexibilização do direito do trabalho, cit., p. 216.
} 
de trabalhadores e de empresários, operando com um tipo novo e singular de normas jurídicas (o pacto ou a convenção coletiva das condições de trabalho)". ${ }^{34}$

O autor completa afirmando que "enquanto a regulamentação estatal é tipicamente heterônoma, a regulação convencionada ou pactuada se caracteriza por certo grau de autonomia, além de que sua tendência é concentrar-se sobre questões e problemas gerais, apesar de seu caráter setorial, isto é, de ser referente a coletividades determinadas de trabalhadores e empresários". 35

Amauri Mascaro Nascimento defende que ${ }^{36}$ há duas concepções da autonomia privada coletiva, ou, como prefere o autor, da autonomia coletiva dos particulares. A primeira delas é uma concepção restrita e significa o poder, conferido aos particulares, representantes de trabalhadores e de empregadores, de criar vínculos jurídicos regulamentadores das relações de trabalho. A negociação coletiva figura, nesta concepção, como procedimento para a concretização da autonomia privada coletiva. Desta forma, é construído um conjunto de normas de caráter não estatal, mas que é acolhida pelo Estado. Isso ocorre, sobretudo, nos países que prezam pelos princípios democráticos.

De acordo com a segunda concepção, mais ampla que a primeira, a autonomia privada coletiva é o princípio que fundamenta a negociação coletiva, a liberdade sindical e a greve. Tem, portanto, uma dimensão tríplice: poder de instituir normas e condições de trabalho, liberdade para organizar sindicatos sem prévia autorização estatal ou interferência de qualquer natureza e, finalmente, permissão para o uso da autotutela na defesa dos direitos e interesses, que pode consubstancia-se na paralisação coletiva do trabalho ou em outros atos coletivos legítimos.

Esse sentido mais amplo da autonomia privada coletiva, ao qual se filia Walküre Lopes Ribeiro da Silva, traz a baila, como a própria autora ressalta, um questionamento sobre a relação entre o Estado e a autonomia privada, o que leva, inevitavelmente, à mensuração do grau de democracia e participação do modelo político-jurídico do Estado. ${ }^{37}$

A autora ainda complementa, afirmando que "sob essa ótica, vemos a autonomia privada coletiva alcançar um significado maior, pois de seu exercício resultam não apenas

\footnotetext{
${ }^{34}$ ALONSO OLEA, Manuel. Introdução ao direito do trabalho. Trad. C. A. Barata Silva em colaboração com Darci Rodrigues de Oliveira Santana. 4. ed. São Paulo: LTr, 1984. p. 185.

${ }^{35}$ Id. Ibid., p. 185.

${ }^{36}$ NASCIMENTO, Amauri Mascaro. Teoria geral do direito do trabalho. São Paulo: LTr, 1998. p. 125-126.

${ }^{37}$ SILVA, Walküre Lopes Ribeiro. Autonomia privada coletiva e o direito do trabalho. Revista de Direito do Trabalho, São Paulo, v. 26, n. 97, p. 35, jan./mar. 2000.
} 
acordos, convenções e contratos coletivos de trabalho, mas também os chamados pactos sociais, como a negociação ou concertação social entre o Estado e os atores sociais. A autonomia coletiva pode propiciar, ainda, a participação dos atores sociais no próprio processo legislativo desenvolvido pelo Estado, daí resultando as denominadas leis contratadas ou negociadas, tão comuns na Itália" ${ }^{38}$

Ronaldo Lima dos Santos assegura que "pode-se definir a autonomia privada coletiva no Direito do Trabalho, como o poder de auto-regulação das relações de trabalho, ou de matérias correlatas, pelos grupos profissionais e econômicos, por meio de suas organizações representativas. A negociação coletiva é o seu instrumento, as normas coletivas de trabalho o seu produto". 39

Cabe investigar qual é a natureza desse poder de auto-regulação, se é um poder originário ou um poder derivado em relação ao poder estatal. Norberto Bobbio afirma que, da experiência prática, podemos concluir que os ordenamentos jurídicos são complexos na medida em que as normas que o compõe surgem de mais de uma fonte. Sendo assim, as normas jurídicas são acolhidas pelos ordenamentos jurídicos mediante mecanismos de recepção ou de delegação, surgindo então, a distinção entre fonte originária e derivada. A autonomia privada coletiva será fonte originária na mediada em que, de acordo com o pensamento de John Locke, há um resíduo de poder normativo natural, quando da celebração do contrato social, ou será um poder derivado, numa aproximação da teoria de Thomas Hobbes, com a transferência de todo o poder que tinham os indivíduos. ${ }^{40} \mathrm{~A}$ doutrina juslaboralista italiana da atualidade, de modo consensual, defende que a natureza da autonomia privada coletiva é de poder originário, ao contrário da concepção sustentada pelo doutrinadores no período fascista. ${ }^{41}$

No que tange ao objeto de estudo dessa dissertação, que é o direito de greve dos servidores públicos, a autonomia privada coletiva ganha relevância na medida em que viabiliza a participação desses trabalhadores na definição das suas condições de trabalho. Essa possibilidade de acompanhamento ativo do processo legislativo por parte dos servidores organizados em sindicatos, embasada na autonomia coletiva, garantiria a

\footnotetext{
${ }^{38}$ SILVA, Walküre Lopes Ribeiro. Autonomia privada coletiva e o direito do trabalho, cit., p. 35.

${ }^{39}$ SANTOS, Ronaldo Lima dos. Teoria das normas coletivas. São Paulo: LTr, 2007. p. 131.

${ }^{40}$ BOBBIO, Norberto. Teoria do ordenamento jurídico. Trad. Maria Celeste C. J. Santos. 10. ed. Brasília: Ed. da UnB, 1997. p. 37-44.

${ }^{41}$ SILVA, Walküre Lopes Ribeiro. Autonomia privada coletiva e o direito do trabalho, cit., p. 30.
} 
sustentação de um regime jurídico contratual ao servidor público, que tradicionalmente é o regime institucional.

\subsection{Pilares do direito coletivo do trabalho}

Sobre esses dois princípios do direito coletivo do trabalho, liberdade sindical e autonomia privada coletiva, erguem-se três pilares que completam a estrutura do edifício direito coletivo do trabalho: a sindicalização, a negociação coletiva de trabalho e a greve. Esses pilares são interligados, de forma que qualquer abalo em um deles é sentido pelos demais. Sendo assim, faz-se necessário um estudo conjunto desses institutos no sentido de verificar a necessidade de harmonização de todo o sistema de normas coletivas do trabalho.

Robertônio Santos Pessoa sustenta que "o direito de greve é inerente ao conceito de liberdade sindical, sendo mesmo um complemento indispensável aos procedimentos de negociação coletiva". ${ }^{42}$ Em função disso, ao tratar do direito de greve no serviço público, deve-se, portanto, levar em conta também a sindicalização e a negociação coletiva neste setor.

No setor privado, de um lado, há os trabalhadores e de outro, o empregador. Os primeiros, coletivamente organizados, conseguem angariar força para se contrapor ao empregador, economicamente mais forte. Devido a essa organização em sindicatos, os trabalhadores podem chegar a uma negociação coletiva. Caso essa negociação coletiva resulte infrutífera, resta a greve como forma de pressão. Desta forma, os institutos sindicalização, negociação coletiva e greve são interligados e interdependentes.

\subsubsection{Sindicalização}

A antológica passagem de Aristóteles na qual ele afirma que o "o homem é, por natureza, um animal político" ${ }^{43}$ justifica a necessidade que o ser humano tem de associarse. Essa característica de ser gregário, dada pelas contingências da realidade ou pelo impulso inato, pode explicar, entre tantas outras formas de associativismo, uma em

\footnotetext{
${ }^{42}$ PESSOA, Robertônio Santos. Sindicalismo no setor público. São Paulo: LTr, 1995. p. 75.

${ }^{43}$ ARISTÓTELES. Política. São Paulo: Nova Cultural, 1999. p. 144.
} 
particular: o sindicalismo. Além disso, como assinala Mozart Victor Russomano, facilmente pode-se estabelecer uma relação direta entre a solidariedade dos integrantes do grupo associativo e a existência de interesses comuns entre eles. ${ }^{44}$

Mesmo as contingências da realidade ou a natureza humana, neste aspecto, se confundem, uma vez que, com o passar do tempo, "o hábito cria no homem uma segunda natureza" ${ }^{45}$. A atividade profissional marca os indivíduos de tal forma que os traços característicos, forjados pela repetição do dia-a-dia de trabalho, manifestam-se até mesmo em seus descentes. Isso em função da necessidade permanente de adaptação do corpo e do espírito para o desempenho da atividade profissional. As marcas se verificam no corpo, na indumentária, nas visões de mundo, no imaginário, nos juízos morais, nas opiniões etc. ${ }^{46} \mathrm{O}$ vínculo de solidariedade surge dos traços comuns de maneira espontânea. Como observa Evaristo de Moraes Filho, “os interesses profissionais comuns levam os indivíduos a se aproximarem de modo permanente, criando um órgão próprio e duradouro capaz de lhes defender esses mesmos interesses". 47

Muito embora os sindicatos propriamente ditos tenham surgido um pouco mais tarde, já por volta de 1750 os trabalhadores começaram a agruparem-se. Foram as revoluções industriais, sobretudo, aquelas baseadas na energia hidráulica, no vapor e na eletricidade, que possibilitaram a constituição de agrupamentos gremiais e mutualistas precursoras dos sindicatos dos trabalhadores. ${ }^{48}$

O processo de desenvolvimento das bases da construção normativa da OIT acerca do direito de sindicalização teve uma influência considerável de organizações religiosas. Muitos sindicalistas pioneiros eram membros de congregações anglicanas ou metodistas. ${ }^{49}$ Também a encíclica Rerum novarum teve papel importante neste contexto, pois nela o Papa Leão XIII, em 15 de maio de 1891, afirmava o direito dos trabalhadores de criarem associações de ajuda mútua e de filiarem-se a elas de forma livre e não obrigatória. Além disso, de acordo com esta encíclica, o direito de sindicalização deveria ser reconhecido também aos empregadores. Esse direito, tanto em relação aos trabalhadores como em

\footnotetext{
${ }^{44}$ RUSSOMANO, Mozart Victor. op. cit., p. 1-2.

${ }^{45}$ MORAES FILHO, Evaristo. O problema do sindicato único no Brasil: seus fundamentos sociológicos. 2. ed. São Paulo: Alfa-Omega, 1978. p. 56.

${ }^{46}$ Id. Ibid., p. 57.

${ }^{47}$ Id. Ibid., p. 63.

${ }^{48}$ DUNNING, Harold. op. cit., p. 169.

${ }^{49}$ Id., loc. cit.
} 
relação aos empregadores, é um direito natural dos homens e, por isso, o Estado deveria abster-se de proibi-lo. ${ }^{50}$

A encíclica Rerum novarum, em várias passagens, trata de fundamentos sobre os quais se assentam os princípios que mais tarde foram reconhecidos na Convenção n. 87 da OIT. Muito embora a palavra democracia não conste nem na encíclica nem na convenção, dos dois textos se extrai a idéia de que as associações devem ser instituições de caráter democrático. A encíclica em questão trouxe um movimento dinâmico de criação de sindicatos católicos. ${ }^{51}$

\subsubsection{Negociação coletiva}

Amauri Mascaro Nascimento afirma que "a negociação coletiva é constituída de um conjunto de atos praticados progressivamente sob a forma de procedimento, dos quais resultarão, se as partes concordarem, a convenção ou acordo coletivo. Desse modo, a negociação é a fase precedente, de gestação do acordo normativo e este é o resultado da negociação". 52

Para Octavio Bueno Magano, a negociação coletiva é um processo que tende à superação de conflitos e dele pode resultar uma convenção coletiva ou uma greve. ${ }^{53}$

Pedro Paulo Teixeira Manus assegura que "a negociação coletiva destina-se à celebração do instrumento normativo que irá regular os contratos de trabalho de todos trabalhadores e empregadores submetidos aos limites de representação das partes convenentes ou acordantes". 54

A negociação coletiva de trabalho é a afirmação do pluralismo jurídico e da liberdade sindical, pois dela podem resultar normas jurídicas com base na autonomia privada coletiva e, principalmente, exerce um papel fundamental na construção de um ambiente democrático. $\mathrm{Na}$ verdade, de todas as instituições das relações de trabalho, a negociação coletiva pode ser considerada a mais suscetível a sofrer os impactos da

\footnotetext{
${ }^{50}$ DUNNING, Harold. op. cit., p. 169.

${ }^{51}$ Id., loc. cit.

${ }^{52}$ NASCIMENTO, Amauri Mascaro. Direito sindical, cit., p. 301.

${ }^{53}$ MAGANO, Octavio Bueno. Política do trabalho. São Paulo: LTr, 2001. v. 4, p. 172-173.

${ }^{54}$ MANUS, Pedro Paulo Teixeira. Relações de direito coletivo Brasil-Itália. Coord. Yone Frediani, Domingos Sávio Zainaghi. São Paulo: LTr, 2004. p. 65.
} 
conjuntura política, sendo que seu pleno desenvolvimento ocorre apenas quando o clima político lhe é favorável. ${ }^{55}$

Maurício Godinho Delgado adverte que: “A experiência histórica dos principais países ocidentais demonstrou, desde o século XIX, que uma diversificada e atuante dinâmica de negociação coletiva no cenário das relações laborativas sempre influenciou, positivamente, a estruturação mais democrática do conjunto social. Ao revés, as experiências autoritárias mais proeminentes detectadas caracterizavam-se por um Direito do Trabalho pouco permeável à atuação dos sindicatos obreiros e à negociação coletiva trabalhista, fixando-se na matriz exclusiva ou essencialmente heterônoma de regulação das relações de trabalho". 56

A negociação coletiva de trabalho propicia o diálogo entre trabalhadores, coletivamente organizados, e empregadores. A organização dos trabalhadores minimiza a desigualdade de força que existe entre estes atores sociais.

Uma negociação coletiva bem sucedida resultará em uma norma que passará a regular as condições de trabalho de um grupo de trabalhadores. Essa forma de regulação, pelo seu caráter autocompositivo, apresenta vantagens comparativamente à regulação estatal. É um meio de assegurar a paz social, pois as partes poderão acordar cláusulas de paz. Além disso, esse é um meio mais rápido e eficaz de solução de conflitos comparativamente ao processo legislativo ou ao processo judicial.

A negociação coletiva é um meio de autogestão de interesses de grande relevância e é marcada por celeridade na solução dos conflitos e, também, é uma importante oportunidade de exercício da democracia, servindo de modelo para a atuação coletiva em outras esferas da vida social que não a trabalhista.

A negociação coletiva de trabalho poderá ocorrer em diferentes níveis, conforme o ordenamento jurídico de cada país. A Recomendação n. 163 da Organização Internacional do Trabalho, apregoa que devem ser adotadas medidas adequadas para que as negociações coletivas possam se desenvolver em qualquer nível, especialmente em nível

\footnotetext{
${ }^{55}$ BRONSTEIN, Arturo S.; CÓRDOVA, Éfren. A negociação coletiva. In: CÓRDOVA, Éfren (Dir.). As relações coletivas de trabalho na América Latina: um estudo de seus autores, suas diversas manifestações e seus conflitos, com especial referência ao setor privado. Tradução de Maria Luiza Jacobson. São Paulo: LTr; IBRART; Genebra: Organização Internacional do Trabalho, 1985. p. 112.

${ }^{56}$ DELGADO, Maurício Godinho. Negociação coletiva de trabalho. Revista de Direito do Trabalho, São Paulo, ano 28, n. 107, p. 69, jul./set. 2002.
} 
de estabelecimento, de empresa e de ramo de atividade, de indústria, seja em nível regional ou nacional. ${ }^{57}$

A negociação coletiva de trabalho, assim como muitos institutos do direito coletivo do trabalho, sofre os impactos das profundas transformações provocadas pela mundialização da economia, pelas novas formas de organização do trabalho e da produção e pelas inovações tecnológicas.

Presenciamos, em meio a esta realidade, o crescimento de formas atípicas de trabalho, como, os contratos por tempo determinado, os contratos por tempo parcial, a terceirização; além disso, é flagrante o crescimento das taxas de desemprego; da feminização da mão-de-obra etc.

Domenico De Masi afirma que "a demanda pelo trabalho aumenta porque cresce o número de seres humanos, aumenta o tempo de vida, ingressam no mercado de trabalho novas forças ativas que antes não participavam (mulheres, aposentados, inválidos, etc.); além disso, a facilidade dos deslocamentos físicos faz com que cheguem aos mercados mais ricos multidões de trabalhadores oriundos de mercados mais pobres. Por outro lado, a disponibilidade de trabalho diminui seja porque as novas tecnologias absorvem ofícios antes desempenhados por trabalhadores e por funcionários, seja porque o progresso das ciências da organização permite maximizar sempre mais a combinação dos fatores produtivos". 58

Todos esses fatos repercutem, direta ou indiretamente, na negociação coletiva de trabalho, provocando, desde a diminuição da cobertura das convenções coletivas de trabalho até mesmo a perda de força das entidades sindicais no desenvolvimento das negociações em um ambiente de crise econômica. Também proporcionam a ampliação do uso da negociação coletiva para temas além daqueles relativos às condições de trabalho em sentido estrito, como por exemplo, aquelas que dizem respeito ao emprego, à formação profissional, à inflação etc.

Amauri Mascaro Nascimento, ao tratar do diálogo social como diretriz da União Européia, afirma que "os sindicatos tiveram que negociar outros temas antes não usuais: formas de garantia periódica de empregos, redução dos salários, contratos a prazo,

\footnotetext{
${ }^{57}$ ORGANIZACIÓN INTERNACIONAL DEL TRABAJO. R 163. Recomendación sobre la negociación colectiva, 1981. Disponível em: <http://www.ilo.org/ilolex/spanish/recdisp1.htm>. Acesso em 15 jan. 2009.

${ }^{58}$ DE MASI, Domenico. Desenvolvimento sem trabalho. Trad. Eugênia Deheinzelin, São Paulo: Ed. Esfera, 1999. p. 84.
} 
suspensão temporária do contrato de trabalho, dispensas coletivas, programas de requalificação profissional em colaboração com os governos, compensação de horas etc." ${ }^{\text {,9 }}$

Wagner Giglio ressalta que o resultado das formas autocompositivas de solução dos conflitos dependem de liberdade de negociação, porém isso exige uma igualdade de situação que já não existe mais. A situação econômica atual, com o desemprego crescente, exerce uma pressão que tornam ineficazes as formas tradicionais de composição de conflitos. O autor adverte que, como consequiência, "os resultados dessas formas de autocomposição dos conflitos coletivos de trabalho têm sido desfavoráveis aos trabalhadores: na melhor das hipóteses, são mantidos os direitos anteriores e garantidos, temporariamente, os empregos; na pior, reduzem-se benefícios, negociam-se rescisões contratuais e generaliza-se a insatisfação, que vai eclodir nas etapas seguintes de negociação". 60

Arturo S. Bronstein lembra que atualmente se busca potencializar a negociação coletiva como modo de "flexibilizar" a legislação trabalhista, que supostamente será útil para melhorar a competitividade internacional das empresas frente ao desafio da globalização. ${ }^{61} \mathrm{Na}$ verdade, a negociação coletiva tem funcionado como instrumento de flexibilização dos direitos trabalhistas, já que as condições de negociação das organizações de trabalhadores estão cada vez mais difíceis.

Santiago Pérez Del Castillo observa que: "A negociação coletiva é a forma adotada para possibilitar aos que não são dirigentes participarem na determinação das condições de trabalho. Por este caminho se pretende obter uma harmonia entre os diversos interesses na empresa, especialmente o capital e o trabalho. A ordem jurídica procura o acordo antes do conflito ou, talvez melhor, procura atrair o conflito para áreas de melhores entendimentos". 62

Um dos principais objetivos da Organização Internacional do Trabalho é estimular a negociação coletiva de trabalho em todo o mundo. Isso pode ser comprovado ao se fazer uma analise de como esse instituto foi tratado ao longo da história desse organismo internacional, por meio da sua produção normativa. Iremos verificar que ela caminhou no

\footnotetext{
${ }^{59}$ NASCIMENTO, Amauri Mascaro. O debate sobre negociação coletiva. LTr: revista legislação do trabalho, São Paulo, v. 64, n. 9, p. 1.106, set. 2000.

${ }^{60}$ GIGLIO, Wagner D. Solução dos conflitos coletivos: conciliação, mediação, arbitragem, resolução oficial e outros meios. LTr: revista legislação do trabalho, São Paulo, v. 64, n. 3, p. 311, mar. 2003.

${ }^{61}$ BRONSTEIN, Arturo S. La negociación colectiva: un análisis comparativo. Educación Obrera, n. 114/115, p. 33, 1999. La negociación colectiva; um principio fundamental, um derecho, um convenio.

${ }^{62}$ PÉREZ DEL CASTILlO, Santiago. O direito de greve. Trad. Maria Stella Penteado G. de Abreu. São Paulo: LTr, 1994. p. 12.
} 
sentido da concretização desse objetivo e, como prova disso, há diversos instrumentos normativos que tratam direta ou indiretamente da negociação coletiva. Entre estes instrumentos normativos podemos citar: a Declaração de Filadélfia de 1944; Convenção n. 98; Convenção n. 154; a Recomendação n. 163; Declaração da OIT sobre os Princípios e Direitos Fundamentais no Trabalho de 1998 etc.

No intuito de cumprir a sua missão de promover a negociação coletiva em todo o mundo, a OIT, como podemos comprovar, realizou um intenso trabalho normativo ao longo da sua história. O fomento à negociação coletiva de trabalho, que antes era considerada um fim e objetivo da OIT, alcançou ainda maior importância recentemente, pois foi elevada à condição de princípio fundamental da OIT.

A Declaração da OIT sobre os Princípios e Direitos Fundamentais no Trabalho de 1998 proclamou que todos os seus membros, independentemente de ratificação de convenções, assumem o compromisso em relação aos princípios expressos neste diploma normativo. Esse compromisso decorre tão somente da condição de membro da organização. A declaração, além de reconhecer o efetivo direito de negociação coletiva, adota também como princípios fundamentais: a liberdade sindical; a eliminação de todas as formas de trabalho forçado ou obrigatório; a abolição efetiva de trabalho infantil; a eliminação da discriminação em matéria de emprego e ocupação.

Os órgãos de controle da Organização Internacional do Trabalho apontam, entre outros princípios da negociação coletiva de trabalho, a negociação coletiva livre e voluntária; a liberdade para decidir o nível ou níveis da negociação coletiva e o princípio da boa-fé. ${ }^{63}$

Para Amauri Mascaro Nascimento, “a boa-fé é o princípio básico da negociação coletiva, inspirador da confiança mútua das partes". ${ }^{64}$ Ele observa ainda, que a negociação coletiva "é uma prática reafirmadora da vontade e da autonomia, inafastáveis em um sistema democrático de relações de trabalho, de modo relacionado com os imperativos maiores heterônomos necessários para a devida proteção do trabalhador". ${ }^{65}$

\footnotetext{
${ }^{63}$ GERNIGON, Bernard; ODERO, Alberto; GUIDO, Horacio. Princípios da OIT sobre o direito de greve. In: GERNIGON, Bernard; ODERO, Alberto; GUIDO, Horacio; ERMIDA URIARTE, Oscar. A greve o direito e a flexibilidade. Oficina Internacional del Trabajo. Secretaria Internacional do Trabalho. Brasília: OIT, 2002. p. 44-47.

${ }^{64}$ NASCIMENTO, Amauri Mascaro. Compêndio de direito sindical, cit., p. 318.

${ }^{65}$ Id. Teoria geral do direito do trabalho, cit., p. 123.
} 


\subsubsection{Greve}

Enoque Ribeiro dos Santos assevera que "a greve emana do exercício da autonomia privada coletiva pelos grupos sociais organizados, é reconhecida pelos modernos ordenamentos jurídicos e, configura-se em um instrumento de pressão utilizado pelos trabalhadores para compelir os empregadores ao atendimento de seu rol de reivindicações". ${ }^{66} \mathrm{O}$ autor ainda adverte que a negociação coletiva de trabalho não teria qualquer eficácia, caso não houvesse o direito de greve.

A greve, além de um direito, é um poder equilibrador ${ }^{67}$, uma vez que é um instrumento de autotutela de que dispõe o trabalhador para a defesa dos seus interesses, já que se encontra em uma posição de inferioridade econômica em relação ao empregador.

O direito do trabalho pode ser considerado um ramo atípico do Direito, sobretudo, o direito coletivo do trabalho. Para este último, a noção de autotutela e de greve, reveladoras do conflito que, para os demais ramos do Direito, são vistas como anomalia, é considerada o tipo, o princípio. ${ }^{68}$

Sendo assim, no direito coletivo do trabalho, "o conflito é um dos tipos; é normal; é o princípio ou regra. E a tal ponto que sua principal manifestação e instrumento foram elevados à categoria de direito fundamental, reconhecido nas constituições de declarações internacionais". 69

\subsubsection{Conflitos coletivos de trabalho}

Os termos conflito, controvérsia e dissídio caracterizam as lides trabalhistas de natureza coletiva e são tratadas por alguns doutrinadores como sinônimos, porém outros fazem distinção entre eles. ${ }^{70}$ Neste último caso, conflito assume um sentido amplo de contraste de interesses; controvérsia, o de conflito em via de solução e dissídio, o de conflito em via de solução jurisdicional.

\footnotetext{
${ }^{66}$ SANTOS, Enoque Ribeiro dos. Fundamentos do direito coletivo do trabalho: nos Estados Unidos da América, na União Européia, no Mercosul e a experiência brasileira. Rio de Janeiro: Lúmen Júris, 2005. p. 242.

${ }^{67}$ ERMIDA URIARTE, Oscar. op. cit., p. 10.

${ }^{68}$ Id. Ibid., p. 10-11.

${ }^{69}$ Id. Ibid., p. 11.

${ }^{70}$ MAGANO, Octavio Bueno. Direito coletivo do trabalho, cit., p. 180.
} 
O conflito coletivo de trabalho é a divergência, resultante de pretensão resistida, em face de determinado interesse de natureza coletiva. ${ }^{71}$ Portanto, os sujeitos envolvidos são grupo de trabalhadores, de um lado, e empregador ou grupo de empregadores, de outro. Além disso, o objeto da divergência corresponde ao interesse do próprio grupo ou de seus membros coletivamente considerados. Na relação processual, estabelecida em função do conflito coletivo de trabalho, os sujeitos são entidades representativas das categorias em litígio, por isso, os titulares dos interesses em disputa são indeterminados, tanto quanto ao número como quanto à identidade. ${ }^{72}$

Os conflitos coletivos de trabalho podem ser classificados, sob o critério da finalidade, em conflitos de natureza jurídica e conflitos de natureza econômica, também chamados de conflitos de interesse.

Esse critério de classificação, proposto e adotado pela Organização Internacional do Trabalho em 1938, apresenta evidentes imprecisões. ${ }^{73}$ Os conflitos jurídicos são conflitos de interesses, uma vez que são resultantes do choque entre interesses juridicamente protegidos. O mesmo ocorre com os conflitos econômicos, porque a sentença, ao criar ou modificar as condições de trabalho, também é jurídica.

Os conflitos econômicos, ou de interesse, são aqueles "nos quais os trabalhadores reivindicam novas e melhores condições de trabalho". ${ }^{74}$ Os conflitos jurídicos, por sua vez, são aqueles que visam “dar execução adequada à norma jurídica em vigor". ${ }^{7}$

Amauri Mascaro Nascimento observa que, enquanto nos conflitos econômicos a finalidade é a obtenção de um novo contrato coletivo de trabalho, nos conflitos jurídicos, é "a declaração sobre o sentido de um contrato coletivo ou de uma ou mais de uma cláusula de um contrato coletivo ou a execução de uma norma que o empregador não cumpre". ${ }^{76}$

Octavio Bueno Magano ressalta que "conflitos coletivos” é expressão genérica que abrange os conflitos que se traduzem em vias de fato, controvérsias e dissídios. Excluindo-se essas duas últimas espécies, isto é, não se tratando de conflitos em via de solução, judicial ou não, estaremos diante dos conflitos coletivos "stricto sensu". Entre as figuras presentes nesta espécie estão as formas de ação direta como a greve, o lock-out, o

\footnotetext{
${ }^{71}$ MAGANO, Octavio Bueno. Direito coletivo do trabalho, cit., p. 180-181.

${ }^{72}$ RUSSOMANO, Mozart Victor. op. cit., p. 228.

${ }^{73}$ Id. Ibid., p. 230-231.

${ }^{74}$ NASCIMENTO, Amauri Mascaro. Compêndio de direito sindical, cit., p. 289.

${ }^{75}$ RUSSOMANO, Mozart Victor. op. cit., p. 230.

${ }^{76}$ NASCIMENTO, Amauri Mascaro. Compêndio de direito sindical, cit., p. 289.
} 
picketing, a boicotagem e a sabotagem. ${ }^{77}$ No entanto, Mozart Victor Russomano afirma que a greve não é um conflito, mas o instrumento usado para solucionar o conflito. ${ }^{78}$

\subsubsection{Histórico}

Havia uma controvérsia, hoje superada, sobre o surgimento da greve. Ignorava-se que nem todos os fatos sociais que provocavam a paralisação do trabalho podem ser considerados greves. Para muitos autores ela tinha uma origem bastante remota. Isso ocorria devido ao fato dela ser confundida com as rebeliões de escravos ou mesmo porque manifestações de caráter nitidamente sociais e políticos eram interpretadas como greve. ${ }^{79}$

Havia autores que consideravam que as primeiras greves surgiram no Egito Antigo durante a construção do templo de MUT e greves de caráter religioso no Império Médio. ${ }^{80}$ O êxodo dos hebreus, ao deixarem o Egito, também era indicado por alguns autores como um desses primeiros movimentos de massa, enquanto outros indicavam a saída dos plebeus de Roma para o Monte Arentino que se rebelavam contra os privilégios políticos e sociais dos patrícios. ${ }^{81}$

Em vários momentos na antiguidade houve interrupção abrupta e coletiva do trabalho, tanto por parte dos trabalhadores como por parte dos comerciantes. ${ }^{82}$ Atitudes foram tomadas como forma de coibir essas ações como podemos comprovar nas duas constituições de Zenon: (i) as que estabeleciam penas para os trabalhadores que se recusassem a trabalhar ou que impedissem outros de trabalhar, a chamada de aedificüs privatis; (ii) as que previam penas para os negociantes e artesãos que se unissem com o intuito de elevação dos preços, de monopoplüs. ${ }^{83}$

No entanto, é importante observar que essas manifestações e paralisações de trabalho na antiguidade estão mais para rebeliões de povos escravizados contra os seus

\footnotetext{
${ }^{77}$ MAGANO, Octavio Bueno. Direito coletivo do trabalho, cit., p. 185.

${ }^{78}$ RUSSOMANO, Mozart Victor. op. cit., p. 244-245.

${ }^{79}$ VIANNA, José de Segadas. op. cit., p. 193.

${ }^{80}$ Id. Ibid., p. 194.

${ }^{81}$ RUSSOMANO, Mozart Victor. op. cit., p. 242.

${ }^{82}$ Id. Ibid., p. 243.

${ }^{83}$ VIANNA, José de Segadas. op. cit., p. 195.
} 
opressores do que propriamente para greve, pois faltava um elemento essencial para a sua caracterização que é a liberdade. ${ }^{84}$

Orlando Gomes e Elson Gottschalk afirmam que "a greve, com efeito, era fenômeno desconhecido na antigüidade - porque de greve não se pode falar onde liberdade de trabalho não existe. Não tinha o escravo senão uma maneira para se abster de trabalhar: fugir. Para a ocorrência do fenômeno exige-se o fator psicológico da consciência de classe, o senso de antagonismo de interesses". ${ }^{85}$

Na atualidade é incontroversa a idéia de que a greve é um fenômeno pertencente à Idade Moderna, sendo a sua origem coincidente com o surgimento da industrialização e como uma das manifestações da liberdade de trabalho propugnada pela Revolução Francesa. ${ }^{86}$ A greve eclodiu como uma força elementar da natureza, nos primórdios da organização industrial, como uma reação espontânea das massas operárias frente a uma situação econômica e de abandono em função da exposição a jornadas de trabalho extenuantes executados em meio a condições desumanas. ${ }^{87}$ Até mesmo a palavra greve "se origina do fato dos operários parisienses se reunirem na "Palce de la Grève", quando abandonavam o trabalho". ${ }^{88}$

Piero Calamandrei ao analisar a greve como expressão da concessão política do Estado diferencia três valores a ela atribuídos ao longo da história: a greve como delito, a greve como liberdade e a greve como direito. ${ }^{89}$

Esta distinção introduzida por Calamandrei a respeito da evolução do tratamento jurídico da greve que se tornou clássica ${ }^{90}$ e reflete as posições do Estado em relação a este instituto ao longo da história e carrega consigo conseqüências práticas, ${ }^{91}$ como veremos a seguir.

\footnotetext{
${ }^{84}$ VIANNA, José de Segadas. op. cit., p. 194.

${ }^{85}$ GOMES, Orlando; GOTTSCHALK, Elson. Curso de direito do trabalho. 4. ed. Rio de Janeiro: Forense, 1995. p. 620.

${ }^{86}$ RUSSOMANO, Mozart Victor. op. cit., p. 243.

${ }^{87}$ GOTTSCHALK, Egon Felix. Greve e lock-out: seus efeitos sobre o contrato individual de trabalho, uma contribuição à doutrina do direito coletivo do trabalho. São Paulo: Max Limonad, 1961. p. 11.

${ }^{88}$ CESARINO JUNIOR, A. F. Direito social brasileiro. 2. ed. São Paulo: Martins, 1943. v. 2, p. 21.

${ }^{89}$ CALAMANDREI, Piero. Significato costituzionale del diritto del sciopero. In: CAPPELLETTI, Mauro (a cura di). Opere giuridiche. Napoli: Morano,1968. v. 3, p. 446-447.

${ }^{90}$ PÉREZ DEL CASTILLO, Santiago. op. cit., p. 42.

${ }^{91}$ LÓPEZ-MONÍS DE CAVO, Carlos. O direito de greve: experiências internacionais e doutrina da OIT. São Paulo: LTr, 1986. p. 11.
} 
De acordo com essa distinção a greve passou de delito a ilícito civil, posteriormente ganhou status de liberdade, sem gerar responsabilidades e, por fim, houve o reconhecimento da greve como direito no plano legal ou constitucional.

Em praticamente todos os países houve uma perseguição penal à figura da greve por ser considerada socialmente prejudicial, ${ }^{92}$ sobretudo, devido à constatação de que configurava um extraordinário poder dos trabalhadores. Como o passar do tempo a greve deixou de ser entendida como conflito de trabalho, mas como instrumento de solução de conflitos, ${ }^{93}$ fato que levou a uma mudança progressiva de concepção que culminou com a idéia de greve como direito.

Entre os Estados que passaram a declarar as greves ilícitas, com punição prevista, muitas vezes, na legislação penal, estão a Inglaterra, no século XIV, e a França e a Alemanha, no século XVI. ${ }^{94}$

É importante observar que a repressão penal da greve está estreitamente ligada ao conceito de coalizão, ${ }^{95}$ de forma que as proibições dos Estados relativas às coalizões que serão analisadas a seguir implicam também na proibição à greve.

$\mathrm{Na}$ Inglaterra as leis contra as coalizões já podiam ser observadas desde 1305 durante o reinado de Eduardo I e, ainda na Inglaterra, leis especiais de 1428, de 1548 e de 1727 estabeleciam que os grevistas eram considerados culpados de alta traição e passíveis de sevícias como o corte de orelhas, trabalhos de galés, assim como, podiam ser condenados a pena de morte. ${ }^{96}$

Em 1537, na Alemanha, uma greve na cidade de Colônia foi reprimida de forma bastante violenta com o enforcamento de 32 grevistas e, também, havia previsão nas Ordenanças Imperiais de 1577 e 1731 de penas graves para as coalizões. ${ }^{97}$

O liberalismo da Revolução Francesa de 1789 era contrário a existência de corpos intermediários na sociedade que se posicionavam entre os indivíduos e o Estado. A proibição de agrupamentos de trabalhadores pretendia inviabilizar qualquer possibilidade de ressurreição de entidades corporativas. Foi editada uma lei em 1791, chamada Le Chapelier que proibia os cidadãos de formarem qualquer tipo de reunião para discutir

\footnotetext{
${ }^{92}$ PÉREZ DEL CASTILLO, Santiago. op. cit., p. 42.

${ }^{93}$ RUSSOMANO, Mozart Victor. op. cit., p. 244.

${ }^{94}$ Id., loc. cit.

${ }^{95}$ PÉREZ DEL CASTILLO, Santiago. op. cit., p. 42.

${ }^{96}$ VIANNA, José de Segadas. op. cit., p. 196.

${ }^{97}$ Id. Ibid., p. 196.
} 
sobre os seus interesses comuns e, também, as greves. Elas eram vistas como atentatórias à liberdade individual e à Declaração de Direitos. ${ }^{98}$ O Código Penal de Napoleão de 1810 previa que a associação de trabalhadores era um delito. ${ }^{99}$ Uma lei de 25 de maio de 1864 modificou o Código Penal, suprimindo o delito de coalizão e introduzindo o de atentado contra a liberdade de trabalho. Eram penalizados os atos de ameaça, violência ou coação para impedir o trabalho. ${ }^{100}$

Como bem observa Wilson de Souza Campos Batalha, "a proibição das greves tinha, então, um sentido político indisfarçável. Poderiam elas constituir o nascedouro de movimentos sindicalistas que procurassem destruir os princípios básicos da Revolução, entre os quais se encontrava o que punha o indivíduo perante o Estado, sem organismos sociais intermediários que pudessem atentar contra a liberdade de trabalho. A antinomia filosófica de proibição das greves resolvia-se no plano político da mentalidade revolucionária. Posteriormente, a Lei de 22 Germinal ano XI (12 de abril de 1803) puniu as coalizões e quaisquer agrupamentos de trabalhadores, mesmo transitórios, colimando à greve. Tais punições reapareceriam no Código Penal de 1810". ${ }^{101}$

Em outros países europeus esta situação da greve como delito também ocorria. $\mathrm{Na}$ Hungria, cujo abandono do trabalho por camponeses era punido com pena de prisão por 60 dias; na Itália, o Codice Penale Sard, de 1859, "considerou crime toda forma de coalizão dos empregadores, para reduzir salários, e dos operários, para suspender o trabalho" ${ }^{102}$; nos países escandinavos, cujas leis de 1867 e 1899 puniam severamente as coalizões; e mesmo na Rússia czarista. ${ }^{103}$

Posteriormente, a greve deixa de ser considerada um delito e passa à condição de liberdade. No entanto, essas transformações não ocorreram de forma geral, unânime e automática. ${ }^{104}$ Como qualquer outra transformação ideológica, esta ocorre de forma lenta e gradual. Em função disso, a greve deixa de ser um delito, porém, ainda não passa a ser um direito, mas sim uma liberdade.

\footnotetext{
${ }^{98}$ BATALHA, Wilson de Souza Campos. Relações coletivas do trabalho: conflitos abertos do trabalho e sua solução. São Paulo: Federação e Centro das Indústrias, 1958. p. 20.

${ }^{99}$ NASCIMENTO, Amauri Mascaro. Compêndio de direito sindical, cit., p. 39-41.

${ }^{100}$ VIDAL NETO, Pedro. O direito de greve: evolução histórica. In: PRADO, Ney (Coord.). Direito sindical brasileiro. São Paulo:LTr, 1998. p. 305.

${ }^{101}$ BATALHA, Wilson de Souza Campos. op. cit, p. 21.

${ }^{102}$ NASCIMENTO, Amauri Mascaro. Compêndio de direito sindical, cit., p. 41.

${ }^{103}$ VIANNA, José de Segadas. op. cit., p. 197.

${ }^{104}$ RUSSOMANO, Mozart Victor. op. cit., p. 244.
} 
Nesta situação, para alguns autores, o Estado toma um posicionamento de indiferença diante dos movimentos paredistas dos trabalhadores, ${ }^{105}$ os quais passam a ter liberdade para utilizar a greve como meio de protesto, interrompendo as suas atividades e abandonando os locais de trabalho. No entanto, apesar da greve, neste momento, não ser mais punível na esfera do direito penal, os empregadores poderiam considerá-la como abandono de emprego, ou seja, um descumprimento contratual, podendo levar à ruptura do vínculo empregatício com a extinção do contrato de trabalho ${ }^{106}$.

Octavio Bueno Magano não corrobora a idéia de indiferença do Estado diante da greve-liberdade. $\mathrm{O}$ autor justifica o seu posicionamento argumentando que a permissão da greve, ainda que sem a proteção especial do Estado, por si só, já é suficiente para a sua admissão como um valor, isto é, a greve somente seria valorada negativamente se fosse considerada um delito. ${ }^{107}$

A concepção da greve como liberdade, sem sombra de dúvidas constitui um avanço do ponto de vista da evolução desse instituto em relação à concepção anteriormente adotada, isto é, a greve entendida como delito. Porém, aquela acarreta uma série de conseqüências do ponto de vista prático que não podemos deixar de levar em consideração. Além daquelas relativas ao próprio contrato de trabalho, mencionadas anteriormente, existe a possibilidade da greve como liberdade poder ser reprimida mais facilmente sob outros argumentos como a ordem pública e o interesse público.

Não podemos também esquecer que a greve não deixa de ser uma autotutela, admitida no direito excepcionalmente e aceita apenas no direito do trabalho como instrumento para solução de conflitos. Ela é um fenômeno estranho, no seu berço, às instituições tradicionais do direito. ${ }^{108}$ Essa característica de autotutela da greve acarreta uma certa tendência no mundo jurídico de limitá-la ou mesmo reprimi-la, daí a necessidade de uma proteção especial deste instituto por parte do Estado, reconhecendo-a como direito.

A greve como direito surgiu dessa necessidade de proteção especial. De acordo com essa concepção o trabalhador em greve passa a exercer um direito não mais em relação ao Estado, mas em relação ao empregador. ${ }^{109}$ Este, portanto, obrigado-se, a partir

\footnotetext{
${ }^{105}$ PÉREZ DEL CASTILLO, Santiago. op. cit., p. 42.

${ }^{106}$ VIDAL NETO, Pedro. op. cit., p. 303.

${ }^{107}$ MAGANO, Octavio Bueno. Direito coletivo do trabalho, cit., p. 186.

${ }^{108}$ GOTTSCHALK, Egon Felix. op. cit., p. 12.

${ }^{109}$ PÉREZ DEL CASTILLO, Santiago. op. cit., p. 43.
} 
de então, a respeitar esse direito e não poderá considerar extinto o contrato de trabalho, que será apenas suspenso durante o período de greve.

Amauri Mascaro nascimento afirma que "a greve não tem a finalidade de romper o contrato de trabalho definitivamente. A greve não extingue o contrato individual, diante da sua função, que é a manutenção do vínculo em condições diferentes das em que se verifica. Com isso, fica totalmente afastada a hipótese da greve como abandono de emprego, à falta de elemento intencional do abandono, que é o propósito de dar por rescindido o contrato. A intenção dos trabalhadores na greve não é resolutória, mas suspensiva da relação. ${ }^{110}$

O trabalhador não receberá salário durante a greve, porém poderá voltar ao seu posto de trabalho quando a greve terminar. ${ }^{111} \mathrm{O}$ grevista, portanto, não será penalizado penal ou civilmente pela prática da greve a partir de então. ${ }^{112}$

A transição de uma fase à outra ao longo do tempo não ocorreu de forma estanque e linear. As três concepções coexistiram historicamente, uma vez que a abolição da greve como delito variou nos diferentes países: na França ocorreu em 1864, na Alemanha em 1869 e na Itália em 1890. Também não se sucederam no tempo, havendo períodos de retrocesso, com a suspensão da liberdade da greve em alguns períodos como ocorreu na Itália, sob o regime fascista, de 1926 a 1944; na Alemanha, sob o regime nacionalsocialista, de 1933 a 1944; na França, sob o regime de Vicky, de 1940 a 1944 e, finalmente, na Espanha, sob o franquismo, de 1938 a $1975 .{ }^{113}$

Carlos López-Monís de Cavo ensina que "esta mudança de atitude do Estado e de seu ordenamento deve ser explicada com base na mudança de correlação de forças produzidas no interior das sociedades democráticas avançadas, pois, em última análise, o problema do reconhecimento jurídico da greve e de seus limites é reflexo do problema político de correlação de forças sociais antagônicas, num determinado momento histórico". 114

A greve, inicialmente condenada e considerada um delito, passou então a direito consagrado constitucionalmente na Constituição Mexicana de 1917, que em seu artigo 123,

\footnotetext{
${ }^{110}$ NASCIMENTO, Amauri Mascaro. Compêndio de direito sindical, cit., p. 431-432.

${ }^{111}$ LÓPEZ-MONÍS DE CAVO, Carlos. op. cit., p. 12.

${ }^{112}$ VIDAL NETO, Pedro. op. cit., p. 303.

${ }^{113}$ LÓPEZ-MONÍS DE CAVO, Carlos. op. cit., p. 12.

${ }^{114}$ Id. Ibid., p. 13.
} 
XVII estabelece que "las leyes reconocerán como um derecho de los obreros y de los patronos, las huelgas y lo paros". 115

O direito de greve também conta com o reconhecimento em nível internacional, o que pode ser comprovado em vários documentos de organismos internacionais. No entanto, a Organização Internacional do Trabalho não produziu nenhuma convenção a respeito do tema. Essa postura discreta é explicada em função, não do posicionamento desse organismo internacional, que por meio de seus órgãos de controle se mostra favorável ao reconhecimento da greve como direito, mas da posição de alguns países frente ao tema. ${ }^{116}$

O direito de greve, apesar de não estar previsto expressamente no rol dos direitos fundamentais contidos na Declaração Universal dos Direitos do Homem, consta de alguns documentos internacionais como direito merecedor de proteção. Entre estes documentos podemos citar o Pacto Internacional sobre Direitos Econômicos, Sociais e Culturais, adotado pela Assembléia Geral das Nações Unidas, em 1966. O artigo 8, inciso "d" deste documento estabelece que os países que o ratificaram, entre eles o Brasil, se comprometem a garantir "o direito de greve, exercido de conformidade com as leis de cada país". 117

Além disso, em âmbito do continente americano, temos a Ata de Chapultepec, de 1945, e a Carta de Bogotá, de 1948. A primeira é resultado da Conferência de Chapultepec , de 21 de fevereiro a 8 de março de 1945, que inscreverem na "Declaração dos Princípios Sociais da América" o "reconhecimento do direito de associação dos trabalhadores, do contrato coletivo e do direito de greve". ${ }^{118}$ A Carta de Bogotá prevê em seu artigo 27 que: "Os trabalhadores têm direito à greve. A lei regula este direito quanto às suas condições e exercício".

No âmbito europeu, a Carta Social Européia, de 1961, no artigo 6º reconhece que "todos os trabalhadores e empregadores têm o direito de negociar coletivamente". A Carta Comunitária dos Direitos Sociais Fundamentais dos Trabalhadores ${ }^{119}$, adotada em

\footnotetext{
${ }^{115}$ BATALHA, Wilson de Souza Campos. op. cit, p. 27.

${ }^{116}$ PÉREZ DEL CASTILLO, Santiago. op. cit., p. 45.

${ }^{117}$ RANGEL, Vicente Marotta. op. cit., p. 672.

${ }^{118}$ GOTTSCHALK, Egon Felix. op. cit., p. 15-16.

${ }^{119}$ A Carta dos Direitos Sociais Fundamentais dos Trabalhadores, também designada por Carta Social, foi adotada em 1989 sob a forma de uma declaração subscrita por todos os Estados-Membros, com exceção do Reino Unido que só a assinou em 1998. Este documento é considerado um instrumento político que estabelece "obrigações morais" com o objetivo de assegurar o respeito por determinados direitos sociais nos Estados, entre eles, o respeito ao mercado de trabalho, à formação profissional, à proteção social, à igualdade de oportunidade e à saúde e segurança no trabalho. Inclui ainda um pedido expresso à Comissão para que apresente iniciativas destinadas a traduzir o conteúdo da Carta Social em atos legislativos. Na
} 
09/12/1989 pelos chefes de Estado ou de Governo dos países-membros da Comunidade Européia, trata dessa questão em seu artigo $13 .^{120}$

No direito brasileiro a greve passou também por períodos de proibição, de liberdade e de direito, inclusive, constitucionalmente reconhecido, apesar de não nesta ordem, conforme veremos mais adiante ao tratarmos especificamente do direito de greve dos servidores públicos, momento em que faremos um relato sobre a evolução legislativa no Brasil.

\subsubsection{Conceito}

Há na doutrina e nos textos legais diversos conceitos de greve, os quais apresentam alguns elementos comuns, entre eles, podemos citar, a suspensão do trabalho e a forma coletiva de atuação. É importante observar que, "dar uma definição de greve implica por si só um marco de referência e, com toda a segurança, limitações no exercício desse direito". ${ }^{121}$

Pedro Vidal Neto assevera que "as diferentes definições doutrinárias de greve apresentam muitos pontos de convergência, notadamente ao caracterizá-la como suspensão concertada e coletiva do trabalho com propósito de obter melhores condições de trabalho". ${ }^{122}$ Muito embora esses pontos em comum, o próprio autor aponta para a dificuldade de se formular uma definição jurídica genérica de greve, uma vez que o direito positivo impõe ao direito de greve condições e limitações.

Mozart Victor Russomano, por exemplo, define greve como "um fato, naturalmente fato social, mas, também, fato jurídico, que consiste na suspensão do trabalho". ${ }^{123}$ Octavio Bueno Magano também afirma que a greve é, antes de tudo, um fato social, porém nos adverte que sempre foi valorado positiva ou negativamente pelos diferentes sistemas jurídicos da sociedade industrial, sendo considerada, ou um delito ou

sequiência da Carta Social, foram adotados vários programas de ação e propostas legislativas concretas. A Carta dos Direitos Fundamentais, proclamada em Nice em 7 de Dezembro de 2000, retoma, entre outros, os direitos enunciados na Carta Social.

${ }^{120}$ PÉREZ DEL CASTILLO, Santiago. op. cit., p. 45.

${ }^{121}$ LAAT ECHEVERRÍA, Bernardo van der. Conflictos colectivos, huelga y paro patronal. In: ERMIDA URIARTE, Oscar; OJEDA AVILES, Antonio (Coords.). El derecho sindical em America Latina. Montevideo: Fundación de Cultura Universitaria, 1995. p. 230.

${ }^{122}$ VIDAL NETO, Pedro. op. cit., p. 304.

${ }^{123}$ RUSSOMANO, Mozart Victor. op. cit., p. 245. 
uma liberdade ou um direito. ${ }^{124}$ Amauri Mascaro Nascimento apresenta como conceito jurídico de greve "a paralisação combinada do trabalho para o fím de postular uma pretensão perante o empregador". ${ }^{125}$ Portanto, segundo esses autores, a greve pressupõe uma paralisação coletiva do trabalho.

Segundo Orlando Gomes e Elson Gottschalk, um fórmula concisa, na qual estão presentes os elementos necessários para a identificação da greve, pode ser a seguinte: "a greve é uma declaração sindical que condiciona o exercício individual de um direito coletivo de suspensão temporária do trabalho, visando à satisfação de um interesse profissional". 126

No ordenamento jurídico brasileiro, a Lei n. 7.783, de 1989, a greve é definida como a suspensão coletiva, temporária e pacífica da prestação de serviços ao empregador, por deliberação da assembléia geral do sindicato representativo da categoria profissional que deseja melhorar ou manter as condições de trabalho.

A OIT, por meio de seus órgãos de supervisão, não exprime nenhuma definição de greve que possa levar-nos a conclusões sobre a legitimidade das diferentes modalidades de exercício de direito de greve. Apesar disso, o Comitê de Liberdade Sindical, assim como, a Comissão de Peritos avaliam que as restrições em relação aos tipos de greves só se justificam em caso de perda do caráter pacífico do movimento de trabalhadores. ${ }^{127}$

Cesarino Junior afirma que "conforme acertadamente a define o P. Muller, a greve é a recusa coletiva e combinada do trabalho com o fim de obter, pela coação exercida sobre os patrões, sobre o público ou sobre os poderes do Estado, melhores condições de emprego ou correção de certos males dos trabalhadores". ${ }^{128}$ Esta definição é bastante ampla, pois, ao incluir o Estado como parte adversa, elimina a distinção entre a greve de natureza econômica e a greve política. ${ }^{129}$

Carlos López-Monís de Cavo defende que "a ação coletiva dos trabalhadores manifesta-se primordialmente através do conflito e, mais concretamente, através da greve. Por isso, em sentido sociológico descritivo, é insuficiente definir a greve como simples paralisação de trabalho coletivo. A realidade social é muito mais rica. Por greve, deve-se

\footnotetext{
${ }^{124}$ MAGANO, Octavio Bueno. Direito coletivo do trabalho, cit., p. 186.

${ }^{125}$ NASCIMENTO, Amauri Mascaro. Compêndio de direito sindical, cit., p. 427.

${ }^{126}$ GOMES, Orlando; GOTTSCHALK, Elson. op. cit., p. 629.

${ }^{127}$ GERNIGON, Bernard; ODERO, Alberto; GUIDO, Horacio. op. cit., p. 21.

${ }^{128}$ CESARINO JUNIOR, A. F. op. cit., p. 21.

${ }^{129}$ Apud GOTTSCHALK, Egon Felix. op. cit., p. 74.
} 
entender, em sentido amplo, qualquer perturbação no processo produtivo, com abstenção temporária do trabalho ou sem ela". 130

Manuel-Carlos Palomeque López e Manuel Álvarez de La Rosa conceituam greve como "a medida de autotutela básica dos trabalhadores, que consiste na perturbação do processo produtivo do empresário para o qual se presta o trabalho, por meio da realização de diversos comportamentos possíveis e, principalmente, pela abstenção do trabalho, decididos de forma concertada e exercidos coletivamente por trabalhadores para a defesa de seus interesses". 131

Os autores reconhecem que a noção de greve transmitida pela doutrina tradicional e, comumente apresentada pelos diversos ordenamentos jurídicos, se limita a entender que a greve se restringe à cessação temporária da prestação da atividade laboral. ${ }^{132}$ Ao conceituar a greve como comportamentos capazes de perturbar o processo produtivo, e não só como paralisação do trabalho, eles apresentam um conceito que vai além daqueles adotados pela doutrina, que na maioria das vezes o constroem com base, não na realidade dos fatos, mas na limitação imposta pelo ordenamento jurídico do Estado. É importante observar que a greve é, antes de tudo, um fato social e, como tal, não espera autorização ou concordância do Estado para existir. A própria história da greve demonstra isso, na medida em que os movimentos paredistas ocorriam, independentemente de qualquer proibição, inclusive, com a previsão de penas de prisão ou de morte.

Essa postura da doutrina diante do fenômeno da greve é explicada por Oscar Ermida Uriarte pelo fato do "tratamento trabalhista do conflito, em geral, e da greve, em particular, apresenta-se, com muita freqüência, envolto num paradoxo funcional. De um lado, sustenta-se, no plano teórico geral dos princípios e das grandes abstrações, a normalidade e - mais do que isso - a essencialidade do conflito nas relações de trabalho e no Direito do Trabalho. Mas, por outro lado, quando se trata de casos concretos, tende-se a limitar as hipóteses de licitude do conflito e a ampliar suas formas consideradas (por quem?) como anômalas. (...) Por conseguinte, a reação 'natural' do operador perturbado com o fenômeno é tentar limitá-lo, e uma das formas de fazê-lo e deslegitimar algumas de suas modalidades e manifestações". ${ }^{133}$

\footnotetext{
${ }^{130}$ LÓPEZ-MONÍS DE CAVO, Carlos. op. cit., p. 11.

${ }^{131}$ PALOMEQUE LÓPEZ, Manuel Carlos; ÁLVAREZ DE LA ROSA, Manuel. Derecho del trabajo. 2. ed. Madrid: Ed Centro de Estudios Ramon Areces, 1994. p. 497-498.

${ }^{132}$ Id. Ibid., p. 498.

${ }^{133}$ ERMIDA URIARTE, Oscar. op. cit., p. 9-10.
} 
A greve dos servidores públicos também sofre com esse paradoxo, uma vez que a doutrina e a jurisprudência, sobretudo no Brasil, geralmente, não tem um posicionamento que resulte na efetivação desse direito. O caminho mais tranqüilo; do ponto de vista do enfrentamento de uma situação conflituosa, que carrega consigo elementos ainda mais complexos que aqueles que envolvem as greves em geral, é a sua negação, por meio de construções teóricas que não garantem a efetivação desse direito. Esse tema será retomado mais adiante e de forma mais profunda, antes faremos um estudo acerca das modalidades de greve, bem como, serão apresentadas diferentes classificações apontadas pela doutrina.

\subsubsection{Modalidades}

O direito de greve é fruto de uma construção histórica que passou por diversos estágios, cuja concepção passou de delito a direito consagrado constitucionalmente, conforme já foi analisado anteriormente. Esse fenômeno, antes de tudo, é um fato social e a sua admissão pelo direito procura muitas vezes enquadrá-lo em um formato pré-concebido. No entanto, como qualquer outro fenômeno social, a greve tem como característica o dinamismo, isto é, ela ocorre de diversas formas conforme as exigências da realidade que a rodeia. Em razão disso, é natural que os doutrinadores procurem entender o instituto, agrupando-o, segundo suas características peculiares, e construam modelos de classificação.

Orlando Gomes e Elson Gottschalk classificam as greves com base no critério finalidade. Esta escolha se dá por considerarem que a greve não é um fím em si mesmo, mas um meio a serviço de um fim. Sendo assim, esses autores classificam as greves com base nos seus fins, o que resulta em dividi-las em típicas e atípicas. As primeiras são aquelas tuteladas pelo modelo legal, as chamadas greves contratuais, cujos fins são os econômico-profissionais. As segundas, podem se apresentar sob diversas formas e serem subdividas em relação aos sujeitos, aos modos de exercício, aos fins a serem alcançados. ${ }^{134}$

Octavio Bueno Magano nos apresenta uma classificação segundo a qual é possível identificar o fenômeno da greve sob três critérios distintos: o da extensão, caso ela seja global, parcial ou de empresa; o de modo de exercício, caso em que ela pode ser contínua,

\footnotetext{
${ }^{134}$ GOMES, Orlando; GOTTSCHALK, Elson. op. cit., p. 636.
} 
intermitente, branca ou por etapas (tournante) e, finalmente, o de objetivos, caso em que a greve pode ser profissional, de solidariedade ou política. ${ }^{135}$

Mozart Victor Russomano adota como critérios de classificação os modos como as greves se desenvolvem, o que ele denomina de critérios formais de classificação. ${ }^{136}$ Segundo este modelo, como o autor mesmo afirma, insuficiente e passível de complementação, a greve pode ser classificada quanto às causas, quanto à extensão, quanto à duração, quanto à categoria profissional dos trabalhadores grevistas e quanto aos métodos de desenvolvimento da greve. Nesta classificação a greve quanto às causas podem ser típicas, quando tratar-se de movimentos que tenham como objetivo modificar ou manter as condições de trabalho; de solidariedade, quando envolverem a cooperação entre várias categorias e, finalmente, greves políticas. Quanto ao critério extensão, as greves podem ser de empresa ou estabelecimento; de categoria e, também, gerais, com amplitude local, regional ou nacional. Em relação à duração, a greve pode ser por tempo determinado ou por tempo indeterminado. Quanto à categoria profissional dos trabalhadores grevistas, a greve pode ser no setor privado ou no setor público. Quanto aos métodos de desenvolvimento, as greves podem ser pacíficas ou violentas.

Numa classificação mais ampla, Russomano aponta ainda a possibilidade de dividir as greves sob critérios substanciais, ou seja, pela maneira como elas estão insertas e admitidas no sistema jurídico dos países. ${ }^{137}$ De acordo com esses critérios, as greves podem ser classificadas em greves legítimas e ilegítimas; greves legais e ilegais; greves justas e injustas.

É importante observar que a greve é considerada um direito e, sendo assim, não mais se pode falar em greve ilegal. Hodiernamente, usa-se a denominação greve abusiva quando ocorre qualquer irregularidade.

Brioschi e Setti apontam para a existência de greve com objetivos contratuais (sciopero a fini), greve de protesto, greve de solidariedade ou de simpatia, greve política, greve geral e greve branca. ${ }^{138}$

\footnotetext{
${ }^{135}$ MAGANO, Octavio Bueno. Direito coletivo do trabalho, cit., p. 197.

${ }^{136}$ RUSSOMANO, Mozart Victor. op. cit., p. 247-248.

${ }^{137}$ Id. Ibid., p. 249-250.

${ }^{138}$ BRIOSCHI, Gian Antonio; SETTI, Federico. Lo sciopero nel diritto: rassegna delle legislazioni dei vari stati. Milano: Giuffrè, 1949. p. 51 e ss.
} 
Para, Manuel-Carlos Palomeque López e Manuel Álvarez de La Rosa, entre os diferentes critérios de classificação das greves, três deles oferecem uma especial relevância para os ordenamentos jurídicos. ${ }^{139}$

No primeiro deles, as greves são diferenciadas em razão dos sujeitos que a realizam, sendo assim, as greves podem ser de trabalhadores da iniciativa privada, vinculados aos seus empregadores por uma relação contratual, e de servidores públicos, com regime jurídico estatutário frente à administração pública e que sofrem, em alguns ordenamentos, limitação, ou mesmo exclusão de alguns de seus seguimentos, no exercício desse direito.

O segundo critério é aquele quanto às causas ou motivação das greves, que faz a distinção em: (i) greve trabalhista e greve extra-trabalhista ou política; (ii) greve de simpatia ou solidariedade.

Finalmente, o terceiro critério de classificação é o do comportamento de greve, ou seja, ao tipo de ação ou omissão praticada pelos trabalhadores durante o movimento grevista. A distinção feita neste caso separa a manifestação típica de greve, que é a cessação do trabalho com o abandono do centro produtivo, de inúmeras outras manifestações ou formas de greves, geralmente denominadas greves atípicas, e que costumam ser limitadas ou proibidas em muitos ordenamentos jurídicos. Entre estas últimas estão: (i) a greve por revezamento ou rotativa, que afeta sucessivamente distintas unidades produtivas que visa afetar a coordenação da produção; (ii) a greve estratégica, tampão ou trombose, afeta apenas a atividade produtiva básica da empresa, mas que causa grande impacto na cadeia produtiva; (iii) greve intermitente, que ocorre em intervalos periódicos em repetição sucessiva; (iv) greve de zelo ou de regulamento, que ocorre mediante extremada observância dos regulamentos, fato que acarreta uma perturbação na prestação dos serviços; (v) greve de trabalho lento, que consiste na diminuição na intensidade e rendimento do trabalho, sem paralisá-lo; (vi) greve de braços cruzados ou greve branca, na qual ocorre a cessação da atividade produtiva, mas com a permanência dos trabalhadores nos seus postos de trabalho; (vii) greve com ocupação do local de trabalho, que se assemelha a anterior, porém os trabalhadores a utilizam como forma de coesão da ação grevista, tais como, a realização de assembléias e arrecadação de fundos.

${ }^{139}$ PALOMEQUE LÓPEZ, Manuel Carlos; ÁLVAREZ DE LA ROSA, Manuel. op. cit., p. 499-501. 
Entre os diferentes tipos de greve merecem atenção especial as chamadas greves de solidariedade e as greves políticas. A greve de solidariedade é aquela realizada por trabalhadores em defesa de interesses alheios, isto é, aquela em que trabalhadores se posicionam em relação a conflitos que não lhes afeta de forma imediata. ${ }^{140}$ A greve política, por sua vez, é aquela dirigida contra os poderes públicos, nacionais ou estrangeiros, com o intuito de conseguir certas reivindicações não susceptíveis de negociação coletiva. ${ }^{141}$

A hipótese da greve de solidariedade ocorre quando um grupo de trabalhadores recorre à greve não em razão de uma pretensão que influencie na sua relação de trabalho, mas para solidarizar-se com a reivindicação de outros grupos ou mesmo contra a lesão de um interesse de um único trabalhador. ${ }^{142}$

A greve de solidariedade pode ser classificada em greve de solidariedade interna ou stricto sensu, quando tratar-se de um ou vários trabalhadores dentro da empresa, e também, greve de solidariedade externa ou de simpatia, quando estabelecida em outra empresa, setor, região ou país. ${ }^{143}$

É importante ressaltar que a greve de solidariedade é proibida em alguns países e permitida em outros, ${ }^{144}$ no entanto, não tem sido enquadrada no âmbito da violação de natureza penal. ${ }^{145}$

A Corte Constitucional italiana reconheceu a legitimidade da greve de solidariedade desde que esteja presente, indubitavelmente, a comunicação de interesses entre as duas categorias envolvidas, a que reivindica e a que lhe dá apoio por meio da greve. ${ }^{146}$

A greve contratual, cujo objetivo é a obtenção de melhores salários e condições de trabalho, ou mesmo, o impedimento de uma piora destes, é considerada a greve original e consagrada juridicamente nas legislações dos vários países. Este objetivo de natureza econômica é natural, fato que impulsionou uma aceitação geral da licitude desse movimento. $^{147}$

\footnotetext{
${ }^{140}$ LÓPEZ-MONÍS DE CAVO, Carlos. op. cit., p. 34.

${ }^{141}$ Id. Ibid., p. 35.

${ }^{142}$ GIUGNI, Gino. Diritto sindacale. 9. ed. Bari: Caduce, 1992. p. 236.

${ }^{143}$ LÓPEZ-MONÍS DE CAVO, Carlos. op. cit., p. 34.

${ }^{144}$ MAGANO, Octavio Bueno. Direito coletivo do trabalho, cit., p. 197-198.

${ }^{145}$ NASCIMENTO, Amauri Mascaro. Iniciação ao direito do trabalho. 20. ed. São Paulo: LTr, 1993. p. 409.

${ }^{146}$ GIUGNI, Gino. op. cit., p. 237.

${ }^{147}$ BRIOSCHI, Gian Antonio; SETTI, Federico. op. cit., p. 51-52.
} 
Essa aceitação não ocorre com tanta facilidade quando as greves apresentam objetivos diversos desses considerados típicos. É o que ocorre com as chamadas greves de solidariedade. Elas acontecem com a participação de trabalhadores alheios ao conflito com o propósito de ajudar um movimento já iniciado, aumentando a probabilidade de sucesso mediante a união de forças. ${ }^{148}$ Elas costumam ser rejeitadas com base nos seguintes argumentos: (i) é injusto que empregadores suportem as consequiências de um conflito que não criou e que não pode solucionar; (ii) são ausentes os interesses diretos na greve de solidariedade, únicos a serem protegidos. ${ }^{149}$

No direito alemão a greve de solidariedade é aceita pela doutrina que defende a teoria da adequação social porque, "apesar de o sujeito passivo da greve não se achar em condições de atender a reivindicação, ele é também um parceiro social e com tal pode influir na atitude de empresa contra a qual o pleito se dirige". 150

A questão central que se apresenta, quando se trata da greve de solidariedade, é determinar se os trabalhadores podem declarar uma greve sem que haja uma repercussão direta e imediata para eles. ${ }^{151}$ A OIT por meio da Comissão de Peritos avalia que a proibição geral das greves de solidariedade poderia ser abusiva, podendo os trabalhadores fazer uso desse recurso desde que a greve inicial que apoiassem fosse legal. ${ }^{152}$ Esse tipo de prática se torna, inclusive cada vez mais freqüente em meio a uma realidade que apresenta uma grande concentração de empresas e de globalização de economia. ${ }^{153}$

A greve política é dirigida aos poderes públicos para buscar a realização de certas reivindicações impossíveis de serem alcançadas mediante a negociação coletiva e podem abranger: (i) as greves revolucionárias ou insurrecionais; (ii) as greves políticas puras, não insurrecionais; (iii) as greves de imposição econômico-política ou mistas. ${ }^{154}$

Da mesma forma que ocorre com a greve de solidariedade, a greve política não é aceita com unanimidade. Existem argumentos contrários e outros favoráveis à licitude dessa modalidade, conforme veremos a seguir.

Os argumentos contrários à licitude da greve política consideram os destinatários da greve e os interesses perseguidos pelo movimento. No primeiro caso, portanto, alegam a

\footnotetext{
${ }^{148}$ BRIOSCHI, Gian Antonio; SETTI, Federico. op. cit., p. 54.

${ }^{149}$ LÓPEZ-MONÍS DE CAVO, Carlos. op. cit., p. 34.

${ }^{150}$ NASCIMENTO, Amauri Mascaro. Comentários à lei de greve. São Paulo: LTr, 1989. p. 32.

${ }^{151}$ GERNIGON, Bernard; ODERO, Alberto; GUIDO, Horacio. op. cit., p. 25.

${ }^{152}$ Id., loc. cit.

${ }^{153}$ Id., loc. cit.

${ }^{154}$ LÓPEZ-MONÍS DE CAVO, Carlos. op. cit., p. 35-36.
} 
não coincidência entre os destinatários da greve e os seus sujeitos passivos, o que impõe aos empregadores suportarem as conseqüências de uma greve numa situação em que não podem atuar no sentido de atender as pretensões solicitadas. No segundo, sustentam que os interesses perseguidos na greve estão na esfera política e, portanto, restritos ao âmbito de atuação dos partidos políticos o que inviabiliza a participação dos sindicatos, cujo interesse deve estar limitado aos interesses profissionais. ${ }^{155}$

Existem também argumentos que defendem a licitude da greve política. O primeiro deles atenta para as características atuais do Estado, que não permitem uma separação nítida entre o Estado e a sociedade e entre a economia e a política. A frequiente intervenção do Estado na economia contribui sobremaneira para esta confusão. Além disso, há o reconhecimento da insuficiência das instituições democráticas da política parlamentar como o voto, os partidos políticos e a ação parlamentar, para alcançar a igualdade substancial dos cidadãos. Essas falhas favorecem a atuação da classe dominante, que dispõem de meios legais para influenciar o processo político, motivo pelo qual os sindicatos, que constituem o grande motor da oposição, podem servir como força compensadora para controle da atuação dos poderes públicos. ${ }^{156}$

A doutrina faz distinção entre a greve política em sentido estrito, que visa o prevalecimento de determinada orientação político-partidária, e a greve de feição econômico-política, cuja pretensão é obter, da autoridade pública, ações concordantes com os interesses das classes trabalhadoras. ${ }^{157}$

Há ainda a distinção entre o modelo contratual, que tutela interesses profissionais ligados ao contrato de trabalho, e o modelo dinâmico, que serve como instrumento de pressão da classe trabalhadora em todas as áreas em que são adotadas decisões de seus interesses. ${ }^{158}$

O Comitê de Liberdade Sindical tem afirmado que os interesses profissionais e econômicos que os trabalhadores defendem mediante o direito de greve englobam, além das relativas a melhores condições de trabalho e de ordem profissional, também as que tratam de soluções para as questões de política econômica e social. E ainda afirma que a declaração de ilegalidade da greve contra as conseqüências sociais e trabalhistas da política

\footnotetext{
${ }^{155}$ LÓPEZ-MONÍS DE CAVO, Carlos. op. cit., p. 36.

${ }^{156}$ Id. Ibid., p. 37.

${ }^{157}$ GIUGNI, Gino. op. cit., p. 233-234.

${ }^{158}$ MAGANO, Octavio Bueno. Direito coletivo do trabalho, cit., p. 198.
} 
econômica do Estado e a sua proibição consiste em uma violação grave da liberdade sindical. ${ }^{159}$

O ordenamento jurídico brasileiro também traz essa questão relativa a qual tipo de interesse os trabalhadores podem defender por meio da greve, se somente os trabalhistas ou se também os políticos e econômicos. Amauri Mascaro Nascimento afirma que "o Congresso Nacional aprovou um texto de amplitude ilimitada ao admitir que os próprios trabalhadores venham a decidir sobre o tipo de interesse a defender através da greve, tão amplo que não cabe à lei ordinária restringi-lo, sob pena de inconstitucionalidade (...) certo também é que a motivação da greve não pode contrariar a natureza mesma do instituto e a sua definição, como meio de pressão destinado a dar força a uma reivindicação ou a um protesto de trabalhadores". 160

Walküre Lopes Ribeiro da Silva defende a mesma posição do autor citado anteriormente e adverte que "não é possível separar completamente o aspecto trabalhista do aspecto político ou econômico de uma reivindicação. Quando se pleiteia melhores salários há indubitavelmente um caráter econômico na luta dos trabalhadores. Entretanto, desvirtuaria o instituto da greve sua utilização com fins político-partidários. Também foge do campo da greve o movimento que se dirija não a fazer pressão sobre os empregadores mas sobre o governo, que não figura como parte nas relações de trabalho". ${ }^{161}$

\subsubsection{Formas consideradas atípicas}

A greve é considerada uma forma de atuação direta, portanto, é gênero dessa espécie. Sendo assim, nem toda ação direta é greve no sentido típico do termo. As greves cujas formas são consideradas atípicas podem estar acompanhadas de atos de violência contra pessoas ou bens. ${ }^{162}$ Entre elas está o boicote, a sabotagem, o piquete, a ocupação de estabelecimento etc

O boicote é um ato coletivo de conflito, mas que não se confunde com a greve. Esse ato consiste na oposição, na obstrução ao negócio de uma pessoa, enfim, na falta de

\footnotetext{
${ }^{159}$ GERNIGON, Bernard; ODERO, Alberto; GUIDO, Horacio. op. cit., p. 23.

${ }^{160}$ NASCIMENTO, Amauri Mascaro. Comentários à lei de greve, cit., p. 33.

${ }^{161}$ SILVA, Walküre Lopes Ribeiro da. A disciplina jurídica da greve e as constituições republicanas no Brasil. Revista da procuradoria Geral do Estado de São Paulo, São Paulo, n. 39, p. 154, jun. 1993.

${ }^{162}$ GOMES, Orlando; GOTTSCHALK, Elson. op. cit., p. 636.
} 
cooperação, ${ }^{163}$ com isso, ocorre o seu isolamento comercial ou de produção com terceiros. ${ }^{164} \mathrm{O}$ termo boicote tem origem no nome de um latifundiário irlandês da metade do século XVIII, James Boycott que submetia seus subordinados a injustos maus-tratos. Ele foi obrigado a abandonar a cidade em que vivia porque os trabalhadores na sua localidade se recusaram a colaborar, implicando numa situação que inviabilizava os seus negócios. ${ }^{165}$

A sabotagem também difere da greve, pois consiste na destruição ou inutilização de máquinas ou mercadorias pelos trabalhadores. Essa palavra tem origem no termo francês sabot, cujo significado é tamanco, quando em meio ao movimento ludista, as máquinas eram danificadas com a colocação desse calçado em suas engrenagens com o objetivo de destruí-las. Com o tempo a palavra passou a identificar todas as ações que produzem danos às instalações industriais, edifícios, instrumentos úteis à produção, à matéria-prima, material de consumo etc. ${ }^{166}$ Esses atos são praticados com o objetivo de protestar violentamente contra o empregador por meio de dano praticado aos seus bens. ${ }^{167}$ Tal meio de atuação não pode ser considerado greve porque, além de ser considerado ato de violência contra coisas também é um ato comissivo, diferentemente da greve que é um ato omissivo. $^{168}$

A sabotagem constitui dano doloso a bem do empregador, visa por meios violentos a destruição do patrimônio alheio. Isso inviabiliza a sua acolhida pelo direito, uma vez que toma características de ilícito penal. Como observa Amauri Mascaro Nascimento, "não pode mesmo ser agasalhada na esfera do direito coletivo, a menos que se queira instaurar nas relações sociais a normalidade da violência, ainda que se queira ver na desigualdade social uma coação econômica exercida pelo empregador". ${ }^{169}$

É importante observar que a greve, por definição, é um movimento pacífico de trabalhadores. Esse caráter é tão importante que os órgãos de controle da OIT têm emitido diversos pronunciamentos no sentido de acolher práticas que ultrapassam o limite da típica interrupção de tarefas, desde que configurem ações pacíficas. ${ }^{170}$

\footnotetext{
${ }^{163}$ NASCIMENTO, Amauri Mascaro. Iniciação ao direito do trabalho, cit., p. 496. ${ }^{164}$ GOMES, Orlando; GOTTSCHALK, Elson. op. cit., p. 640.

${ }^{165}$ NASCIMENTO, Amauri Mascaro. Iniciação ao direito do trabalho, cit., p. 497.

${ }^{166}$ GOMES, Orlando; GOTTSCHALK, Elson. op. cit., p. 639.

${ }^{167}$ NASCIMENTO, Amauri Mascaro. Iniciação ao direito do trabalho, cit., p. 497.

${ }^{168}$ Id. Compêndio de direito sindical, cit, p. 427-428.

${ }^{169}$ Id. Ibid., p. 428.

${ }^{170}$ GERNIGON, Bernard; ODERO, Alberto; GUIDO, Horacio. op. cit., p. 21.
} 
Piquetagem é um método auxiliar da greve e surgiu primeiramente em países de origem anglo-saxônica, por isso deriva do termo picketing. Esse método visa impedir o acesso de não-grevistas ao estabelecimento de trabalho por meio da coação e é feita pela atuação de um grupo de grevistas organizados. ${ }^{171}$

Também pode ser uma forma de pressão dos trabalhadores com a intenção de dissuadir os recalcitrantes que não aderiram ao movimento. Esta forma de atuação é considerada lícita, caso seja pacífica, e ilegal, se violento, tanto no direito estrangeiro como no direito brasileiro. ${ }^{172}$

Os piquetes são utilizados basicamente para tornar efetivas as greves por meio da sua manutenção e extensão e as ações podem ser não-violentas, como, por exemplo, a informação aos trabalhadores ou à opinião pública, as reuniões ou assembléias de formação da base trabalhadora, as atividades de permanência na luta, algumas pressões morais, entre elas, barreiras humanas, colocação de cartazes ou por meio de manifestações em frente ao local de trabalho. Mas, também, podem ser ações violentas, realizadas por meio de ameaças ou agressões físicas que inviabilizem a entrada ou a saída dos trabalhadores, que não aderiram à greve, dos estabelecimentos de trabalho. ${ }^{173}$

Os piquetes estão ligados historicamente à greve como um direito complementar a este, o que serve como justificativa para a sua existência, assim como, a liberdade de pensamento, de expressão e de reunião dos trabalhadores em greve. Mas, podem ser considerados um ilícito pelo ordenamento jurídico, como forma de defesa da liberdade individual de trabalho daqueles que não aderiram à greve. ${ }^{174}$

A ocupação de estabelecimento é chamada pelos americanos de lock-in, configurase pelo comparecimento ao local de trabalho, não para desempenhar as atividades normais do trabalho, mas para ali permanecer sem trabalhar e recusando-se a deixar o local após o término do horário previsto para o fim da jornada normal de trabalho. ${ }^{175}$

Segundo Amauri Mascaro Nascimento, é considerada outra figura externa ao conceito de greve, apesar de haver divergência quanto a isso. É uma prática que consiste na pressão ao empregador por meio da invasão ou permanência dos trabalhadores nos locais

\footnotetext{
${ }^{171}$ GOMES, Orlando; GOTTSCHALK, Elson. op. cit., p. 640.

${ }^{172}$ NASCIMENTO, Amauri Mascaro. Iniciação ao direito do trabalho, cit., p. 497.

${ }^{173}$ LÓPEZ-MONÍS DE CAVO, Carlos. op. cit., p. 52.

${ }^{174}$ Id. Ibid., p. 53.

${ }^{175}$ VIANNA, José de Segadas. op. cit., p. 226.
} 
de trabalho em horas que ultrapassam o período relativo à jornada de trabalho. ${ }^{176}$ Tem por objetivo impedir a produção de forma absoluta, tanto em relação à contratação de novos empregados, como em relação aos trabalhadores que se recusaram a aderir ao movimento. ${ }^{177}$

O seqüestro de pessoas, por vezes, ocorre em conjunto com a ocupação do estabelecimento. Ele é um ato tipificado na legislação penal, que prevê sanções aos seus autores. $^{178}$

\subsubsection{Serviços essenciais}

O Comitê de Liberdade Sindical considera serviços essenciais "aqueles cuja interrupção pode colocar em perigo a vida, a segurança ou a saúde das pessoas, em parte ou na totalidade da população, e não simples incômodo aos cidadãos" e admite, entre eles, "os serviços ferroviários, telefônicos, postais telegráficos, de funcionamento e manutenção de aeroportos, prevenção de contrabando e os serviços alfandegários”. Além disso, esse órgão não julgou essenciais "bancos, empresas petroleiras, monopólios estatais de álcool, fumo, sal, casa da moeda e agência gráfica do Estado". ${ }^{179}$

Segundo Perez Del Castilho, "os serviços essenciais requerem um funcionamento ininterrupto, que projeta sobre aqueles que os exercem um importante obstáculo ao direito." 180

Essa exigência de continuidade também está presente no serviço público. Em razão disso, decidimos tratar detalhadamente esse tema mais adiante quando estivermos lidando especificamente com a greve dos servidores públicos.

\footnotetext{
${ }^{176}$ NASCIMENTO, Amauri Mascaro. Compêndio de direito sindical, cit., p. 428.

${ }^{177}$ VIANNA, José de Segadas. op. cit., p. 226.

${ }^{178}$ NASCIMENTO, Amauri Mascaro. Compêndio de direito sindical, cit., p. 428

${ }^{179}$ Id. Ibid., p. 458-459.

${ }^{180}$ PÉREZ DEL CASTILLO, Santiago. op. cit., p. 43.
} 


\section{DIREITO DE GREVE DOS SERVIDORES PÚBLICOS}

\subsection{Direito de greve no plano internacional}

No plano internacional, o direito de greve está direta ou indiretamente disciplinado em várias normas jurídicas. No âmbito da Organização das Nações Unidas, o direito de greve aparece de forma implícita na Declaração Universal de Direitos Humanos ao garantir o direito de todo o indivíduo de organizar sindicatos para a proteção de seus interesses (artigo XXIII, n. 4) ${ }^{181}$ e de forma explícita no Pacto Internacional sobre Direitos Econômicos, Sociais e Culturais, adotado pela Assembléia Geral das Nações Unidas em Nova Iorque em 16 de dezembro de 1966 ao proclamar o direito de greve no parágrafo 1 , alínea $d$ do artigo $8^{\circ} .^{182}$

A União Européia também apresenta a sua posição em relação ao tema ao declarar textualmente no artigo 6, n.4 da Carta Social Européia, firmada em Turim em 18 de outubro de 1961 pelo Conselho da Europa, que reconhece o direito de greve como forma de assegurar o exercício eficaz da negociação coletiva entre trabalhadores e empregadores “em caso de conflitos de interesse, sob reserva das obrigações decorrentes de convenções coletivas de trabalho". ${ }^{183}$

Além desses instrumentos normativos, a Carta Interamericana de Garantias Sociais, assinada em Bogotá em 1948, por ocasião da IX Conferência Internacional Americana, reconhece o direito de greve. ${ }^{184}$

Como não poderia deixar de ser, a Organização Internacional do Trabalho em função dos seus próprios objetivos ligados à promoção do bem-estar material e moral dos trabalhadores, por meio da dignificação destes, apresenta a sua contribuição no tocante ao direito de greve, a qual será abordada a seguir.

\footnotetext{
${ }^{181}$ RANGEL, Vicente Marotta. op. cit., p. 650.

${ }^{182}$ Id. Ibid., p. 672.

${ }^{183}$ SILVA, Walküre Lopes Ribeiro da. Limites ao direito de greve no contexto democrático: a experiência da Organização Internacional do Trabalho. In: CONGRESSO BRASILEIRO DE DIREITO COLETIVO E DE DIREITO CONSTITUCIONAL DO TRABALHO, 23-24 nov. 1998. Jornal do Congresso. São Paulo: LTr, 1998. p. 31.

${ }^{184}$ Id., loc. cit.
} 


\subsubsection{A Organização Internacional do Trabalho}

Instituída em 1919 pelo Tratado de Versalhes, a Organização Internacional do Trabalho é um organismo internacional com sua sede em Genebra e goza de personalidade jurídica de direito público internacional. Ela é constituída por três órgãos: a Conferência ou Assembléia Geral, o Conselho de Administração e a Repartição Internacional do Trabalho. Ela nasce com o escopo principal de estabelecer a paz universal, fundada na justiça social, conforme o Preâmbulo da Parte XIII do Tratado de Versalhes.

A Organização Internacional do Trabalho tem como um dos elementos distintivos das demais organizações internacionais o fato de não conter qualquer órgão cuja natureza seja exclusivamente intergovernamental. Nos seus dois órgãos representativos, a Conferência Internacional do Trabalho e o Conselho de Administração, os delegados governamentais e os delegados não governamentais participam em pé de igualdade. Ambos os órgãos têm uma composição tripartite, isto é, são compostos por representantes dos poderes públicos, dos empregadores e dos trabalhadores assalariados. O tripartismo é traduzido pelo direito de voto atribuído a cada delegado individualmente e pela formação de três grupos autônomos, governamental, patronal e dos trabalhadores, que deliberam separadamente. $^{185}$

As convenções, as recomendações e as resoluções constituem os instrumentos normativos da OIT. As convenções são tratados que têm como objetivo a uniformização do tratamento internacional dispensado a uma determinada matéria após uma trajetória que compreende discussões e aprovação em uma Conferência Internacional do Trabalho. As recomendações, por sua vez, são diretrizes e normas que podem ser utilizadas para aprimoramento do ordenamento interno dos Estados-membros sobre uma matéria que ainda não alcançou um grau de discussão e consenso necessário para a produção de uma convenção internacional de trabalho. Por fim, as resoluções configuram os instrumentos aprovados pela maioria simples da Conferência Internacional do Trabalho.

É importante lembrar que em relação aos dois primeiros instrumentos há "uma obrigação comum: devem ser submetidas à autoridade nacional competente para aprovar a ratificação da convenção ou para adotar as normas constantes da recomendação. A obrigação, no entanto, é de natureza formal, porquanto essa autoridade é soberana na

\footnotetext{
${ }^{185}$ DINH, Nguyen Quoc; DAILLER, Patrick; PELLET, Alain. Direito internacional público. Lisboa: Fundação Calouste Gulbenkian, 1999. p. 574-575.
} 
deliberação que julgar conveniente tomar, tento em vista os interesses do país". ${ }^{186}$ Vale dizer que elas possuem caráter vinculante em relação aos países-membros, na medida em que os respectivos parlamentos deverão, na medida do possível e ao longo do tempo, incluir o conteúdo delas na legislação interna desses países. Conforme estatui o "art.1 da Constituição da OIT, não apenas as convenções, mas também as recomendações aprovadas pela Conferência Internacional do Trabalho, são transmitidas aos Estados-membros, a fim de que examinem a possibilidade de ratificar as primeiras e de adotar, mediante legislação ou outra forma, as medidas preconizadas nas segundas $\left(\S 5^{\circ}, a\right.$, e $\left.\S 6^{\circ}, a\right) " .{ }^{187}$

A Comissão de Peritos em Aplicação de Convenções e Recomendações e o Comitê de Liberdade Sindical são órgão de controle da OIT. A distinção entre eles está no fato de que "este pode examinar as queixas tanto se o país interessado tenha ratificado como se não tenha ratificado algumas das Convenções da OIT relativas ao tema tratado, já que sua autoridade deriva diretamente da Constituição e, por conseguinte, podem apresentar-se queixas contra qualquer Estado Membro da OIT. Se o governo em questão não ratificou as Convenções pertencentes à OIT, o próprio Comitê de Liberdade Sindical efetua o seguimento das medidas adotadas em relação às queixas. Se as ratificou, a encarregada do seguimento é a Comissão de Peritos em Aplicação das Convenções e Recomendações". ${ }^{188}$

\subsubsection{Perspectiva da OIT em relação ao direito de greve dos servidores públicos}

A Organização Internacional do Trabalho, surpreendentemente, não aprovou nenhuma convenção ou recomendação que trate de forma específica do tema greve. Isso não reflete um descaso por parte desse órgão em relação a esse direito ou que ele se exima de garantir proteção ao seu exercício, muito pelo contrário, pois, o direito de greve tem sido exaustivamente discutido no seio da Conferência Internacional do Trabalho, que, por meio de duas de suas resoluções, que traçam as diretrizes para a política da OIT, insistem no reconhecimento do direito de greve nos Estados membros. ${ }^{189}$

A primeira delas é a Resolução sobre a abolição da legislação anti-sindical nos Estados membros da OIT, adotada em 1967, insiste na adoção de uma "legislação que

\footnotetext{
${ }^{186}$ SÜSSEKIND, Arnaldo. Direito internacional do trabalho. 3. ed. São Paulo: LTr, 2000. p. 182.

${ }^{187}$ Id. Ibid., p. 204.

${ }^{188}$ SWEPSTON, Lee. op. cit., p. 195-196.

${ }^{189}$ GERNIGON, Bernard; ODERO, Alberto; GUIDO, Horacio. Princípios de la OIT sobre la huelga. Revista Internacional del Trabajo, Genebra, v. 117, n. 4, p. 7, 1998 (edición 2000).
} 
assegure o exercício efetivo e sem restrição alguma dos direitos sindicais por parte dos trabalhadores, inclusive o direito de greve”. A segunda é a Resolução sobre direitos sindicais e a sua relação com as liberdades civis, adotada em 1970, que solicitou que o Conselho de Administração recomendasse ao Diretor-Geral uma série de iniciativas "que considerassem novas medidas com vista ao pleno e universal respeito dos direitos sindicais em seu sentido amplo", especialmente, ao "direito de greve". 190

Apesar da ausência de convenção específica sobre o tema, a OIT aborda o direito de greve de forma expressa em outras normas como ocorre na Convenção n. 105, de 1957, que trata da abolição do trabalho forçado, e na Recomendação n. 92, de 1951, que trata da conciliação e arbitragem. Aquela estabelece no artigo $1^{\circ}$, alínea $d$, a proibição de todo trabalho forçado ou obrigatório "como punição por participação em greves" ${ }^{191}$ e esta, nos parágrafos 4 e 6 , prevê que quando um conflito estiver sob efeito de uma conciliação ou de uma arbitragem, "como o consentimento de todas as partes interessadas, deveriam as mesmas ser estimuladas a abster-se de recorrer a greves ou lock outs enquanto dure o procedimento". O parágrafo 7 desse documento adverte que "nenhuma das disposições desta Recomendação pode ser interpretada, de modo algum, em prejuízo do direito de greve". 192

Além disso, a OIT, por meio de seus órgãos de controle, pronuncia-se com profusão sobre o direito de greve. Walküre Lopes Ribeiro da Silva ressalta que "essas breves referências não esgotaram a atuação da OIT no campo da greve, havendo numerosos pronunciamentos do Comitê de Liberdade Sindical do Conselho de Administração e da Comissão de Peritos na Aplicação de Convenções e Recomendações da OIT"' ${ }^{193}$

O Comitê de Liberdade Sindical, como já foi exposto anteriormente, é um órgão que pertence à Organização Internacional do Trabalho e que aprecia as queixas de sindicatos relativas a qualquer possibilidade de violação da liberdade sindical. ${ }^{194}$ Ele reúne suas decisões em uma Recopilação que é publicada periodicamente e estabelecem seus

\footnotetext{
${ }^{190}$ GERNIGON, Bernard; ODERO, Alberto; GUIDO, Horacio. op. cit., p. 7.

${ }^{191}$ ORGANIZACIÓN INTERNACIONAL DEL TRABAJO. Convenção n. 105, OIT. Disponível em: <http://www.ilo.org/ilolex/portug/docs/convdisp1.htm>. Acesso em: 20 jan. 2009.

${ }^{192}$ Id. Recomendación n. 92, OIT. Disponível em: <http://www.ilo.org/ilolex/spanish/recdisp1.htm>. Acesso em: 20 jan. 2009.

${ }^{193}$ SILVA, Walküre Lopes Ribeiro da. Limites ao direito de greve no contexto democrático: a experiência da Organização Internacional do Trabalho, cit., p. 31.

${ }^{194}$ NASCIMENTO, Amauri Mascaro. Compêndio de direito sindical, cit., p. 100.
} 
princípios e orientações de forma minuciosa sobre a legislação e a prática da OIT em matéria de liberdade sindical e proteção do direito de sindicalização. ${ }^{195}$

A respeito do tema direito de greve, especialmente, na função pública o Comitê de Liberdade Sindical apresenta algumas súmulas de jurisprudência que mostram o entendimento atual da Organização Internacional do Trabalho sobre o tema. Entre elas podemos destacar os seguintes verbetes:

" 572 . O reconhecimento do princípio da liberdade sindical aos servidores públicos não implica necessariamente no direito de greve.

573. O Comitê admitiu que o direito de greve pode ser objeto de restrições, inclusive proibições, quando se trate de função pública ou de serviços essenciais, na medida em que a greve puder causar greves prejuízos à coletividade nacional e na condição de que estas restrições venham acompanhadas de certas garantias compensatórias.

574. O direito de greve pode ser limitado ou proibido na função pública somente no caso de funcionários que exerçam funções de autoridade em nome do Estado.

575. Uma definição demasiadamente detalhada do conceito de funcionário público poderia ter como resultado uma restrição muito ampla, e inclusive uma proibição do direito de greve destes trabalhadores. A proibição do direito de greve na função pública deveria limitar-se aos funcionários que exercem funções de autoridade em nome do Estado.

576. O direito de greve pode ser limitado ou proibido: 1) na função pública somente em caso de funcionários que exercem função de autoridade em nome do Estado, ou 2) nos serviços essenciais em sentido estrito do termo (isto é, aqueles serviços cuja interrupção poderá por em perigo a vida, a seguridade ou a saúde de todas as pessoas ou de parte da população.

577. Os "empregados públicos" (que não atuam como órgãos do poder público) de empresas comerciais ou industriais deveriam poder negociar convenções coletivas, disporem de uma proteção adequada contra os atos de discriminação anti-sindical e inclusive desfrutar do direito de greve na medida em que a interrupção dos serviços que prestam não coloquem em perigo a vida, a segurança ou a saúde de todas as pessoas ou de parte da população.

578. A proibição da greve aos trabalhadores no serviço de aduanas, que podem ser considerados funcionários que exercem funções de autoridade em nome do Estado, não é contrária aos princípios da liberdade sindical.

596. Quanto à índole das 'garantias apropriadas' em caso de restrições do direito de greve nos serviços essenciais e na função pública, a limitação da greve deve estar acompanhada por procedimentos de conciliação e arbitragem adequados, imparciais e rápidos no qual os interessados

${ }^{195}$ SWEPSTON, Lee. op. cit., p. 195-196. 
possam participar em todas as etapas, e os laudos pronunciados deveriam ser aplicados por completo e rapidamente."196

A Comissão de Peritos partilha das mesmas posições defendidas pelo Comitê de Liberdade Sindical a respeito do direito de greve. Ambas consideram que ela é um dos meios fundamentais para a efetividade do direito das organizações sindicais e, por isso, fazem a opção pelo reconhecimento do exercício do direito de greve em caráter geral, sendo admitidas como exceções apenas aquelas que podem ser impostas a alguns tipos de servidores públicos e aos trabalhadores ligados aos serviços essenciais em sentido estrito. $^{197}$

A Comissão dos Peritos considera "que o direito de greve é um corolário indissociável do direito de sindicalização garantido pela Convenção n. 87" 198, por isso "as greves não podem ser consideradas isoladamente do conjunto das relações coletivas". 199

Em razão da greve figurar como o meio essencial de promoção e defesa dos interesses dos trabalhadores é preciso adotar um critério não restritivo para definir o segmento dos trabalhadores que podem ser privados do direito de greve, além disso, quando for inevitável a restrição ao direito de greve, ela deve ser a menor possível. ${ }^{200}$

Os órgãos de controle da OIT também observam que o conceito de funcionário público varia muito nos diversos ordenamentos, no entanto, para a Comissão de Peritos e o Comitê de Liberdade Sindical funcionário público, para efeito de exclusão de direito de greve, é somente aquele que exerce função de autoridade em nome do Estado. Este posicionamento tem consequiências importantes, "já que o critério para definir os funcionários públicos excluíveis já não é o fato de lhes ser aplicada a lei nacional de carreira administrativa, mas a natureza das funções que exercem" 201

Observa-se, nos últimos anos, uma evolução dos princípios do Comitê de Liberdade Sindical ao adotar critérios mais rigorosos para definir as categorias de empregados públicos que podem ser proibidos de recorrer ao direito de greve, reduzindo-as àquelas que

${ }^{196}$ ORGANIZACIÓN INTERNACIONAL DEL TRABAJO. OIT: La libertad sindical. Recopilación de decisiones y principios del Comité de Libertad Sindical del Consejo de Administración de la OIT. 5.ed. rev. Ginebra: OIT, 2006. p. 124-129.

${ }^{197}$ GERNIGON, Bernard; ODERO, Alberto; GUIDO, Horacio; ERMIDA URIARTE, Oscar. op. cit., p. 26.

${ }^{198}$ ORGANIZACIÓN INTERNACIONAL DEL TRABAJO. OIT: Estudio General, 1994, parágrafo 197. Disponível em: <http://www.ilo.org/ilolex/spanish/surveyq.htm>. Acessso em: 14 jan. 2009.

${ }^{199}$ SWEPSTON, Lee. op. cit., p. 207.

${ }^{200}$ HODGES-AEBERHARD, Jane; ODERO DE DIOS, Alberto. Los principios del Comité de Libertad Sindical relativos a las huelgas. Revista Internacional del Trabajo, v. 106, n. 4, p. 519, oct./dic. 1987.

${ }^{201}$ GERNIGON, Bernard; ODERO, Alberto; GUIDO, Horacio; ERMIDA URIARTE, Oscar. op. cit., p. 27. 
atuam como órgão do poder público. ${ }^{202}$ Num primeiro momento os órgãos de controle da OIT consideravam que a limitação ao direito de greve poderia ser aplicada aos trabalhadores que atuassem como órgãos do poder público, como os servidores que desempenhassem suas atividades nos ministérios ou outros organismos públicos similares. Posteriormente, por volta dos anos 90, a proibição é admitida aos servidores que exercem alguma função de autoridade em nome do Estado. ${ }^{203}$

É importante ressaltar que esses órgãos fazem um alerta sobre os trabalhadores da administração pública que não exercem autoridade do poder público, mas que exercem um serviço ou atividade essencial no sentido estrito do termo, podendo, portanto, serem excluídos do direito de greve. ${ }^{204}$ Neste caso, quando a legislação nacional faz a opção por privar os funcionários públicos que exercem poder de autoridade e os que atuam nos serviços essenciais do direito de greve, tanto o Comitê de Liberdade Sindical quanto a Comissão de Peritos defendem que devem ser oferecidas, em contrapartida, proteção compensatória, uma vez que esses trabalhadores perderam um dos meios fundamentais para a defesa de seus interesses. Essa proteção compensatória para esses órgãos podem ser tanto os procedimentos de conciliação como os de arbitragem, que devem ser imparciais, céleres, eficientes e gozarem da confiança dos interessados, além da obrigatoriedade para ambas as partes quando da emissão de laudos arbitrais. ${ }^{205}$

$\mathrm{Na}$ maioria dos ordenamentos jurídicos está presente a imposição de várias condições ou requisitos para que a greve seja considerada lícita. Por isso, o Comitê de Liberdade Sindical pronunciou-se no sentido de que essas condições devem ser razoáveis e não podem se tornar numa limitação que impossibilite a ação dos sindicatos. ${ }^{206}$ Além disso, decidiu que seriam aceitáveis os seguintes requisitos: 1) a obrigação de dar aviso prévio; 2) a obrigação de recorrer à conciliação e arbitragem voluntária como condição para declarar a greve; 3) a obrigação de respeitar um determinado quorum de deliberação para a greve; 4) a utilização de escrutínio secreto para que a greve seja declarada; 5) a

\footnotetext{
${ }^{202}$ HODGES-AEBERHARD, Jane; ODERO DE DIOS, Alberto. op. cit., p. 519.

${ }^{203}$ SILVA, Walküre Lopes Ribeiro da. Limites ao direito de greve no contexto democrático: a experiência da Organização Internacional do Trabalho, cit., p. 32.

${ }^{204}$ HODGES-AEBERHARD, Jane; ODERO DE DIOS, Alberto. op. cit., p. 520.

${ }^{205}$ GERNIGON, Bernard; ODERO, Alberto; GUIDO, Horacio; ERMIDA URIARTE, Oscar. op. cit., p. 3334.

${ }^{206}$ HODGES-AEBERHARD, Jane; ODERO DE DIOS, Alberto. op. cit., p. 522.
} 
adoção de medidas para respeitar os regulamentos de segurança e para a prevenção de acidentes; 6) a manutenção de um serviço mínimo. ${ }^{207}$

\subsection{Direito estrangeiro}

Desde os anos 70 e 80 houve uma tendência ao reconhecimento do direito de greve dos servidores públicos, sendo que, na atualidade, esse direito é reconhecido em boa parte dos países, seja por via legislativa ou jurisprudencial. ${ }^{208}$ No entanto, há ainda países que proíbem a greve aos servidores públicos.

Entre os países que proíbem a greve dos servidores públicos podemos citar o Chile. O artigo 19, 16 , inserido no Capítulo III, cujo título é "Dos direito e deveres constitucionais", da Constituição Política da República do Chile, que trata da liberdade do trabalho e sua proteção, estabelece que os funcionários do Estado e das municipalidades não poderão declarar-se em greve. Esta mesma restrição é feita àqueles que trabalham em corporações ou empresas, de qualquer natureza, finalidade ou função, que prestem serviços de utilidade pública ou cuja paralisação cause grave dano à saúde, à economia do Estado, ao abastecimento da população ou à segurança nacional. ${ }^{209}$

Para efeito deste estudo, não faremos uma análise do direito comparado, no entanto, é importante exemplificar casos nos quais o direito de greve é garantido aos servidores públicos. Entre os países mencionados há aqueles que fazem uma previsão constitucional expressa desse direito, como é o caso da Venezuela e do Paraguai.

A Venezuela admite expressamente o direito o direito de greve aos servidores públicos, assim como, o de negociação coletiva, no seu texto constitucional. O artigo 96 da Constituição da República Bolivariana da Venezuela estabelece que todos os trabalhadores, sejam eles do setor público ou do setor privado, têm direito à negociação coletiva voluntária e de celebrar convenções coletivas de trabalho. O artigo 97, por sua

\footnotetext{
${ }^{207}$ SILVA, Walküre Lopes Ribeiro da. Limites ao direito de greve no contexto democrático: a experiência da Organização Internacional do Trabalho, cit., p. 33.

${ }^{208}$ PESSOA, Robertônio Santos. op. cit., p. 76.

${ }^{209}$ CONSTITUIÇÃO POLÍTICA DA REPÚBLICA DO CHILE. Disponível em: $<$ http://www.senado.cl/prontus_senado/antialone.html?page=http://www.senado.cl/prontus_senado/site/arti c/20050516/pags/20050516221649.html>. Acesso em: 11 nov. 2008.
} 
vez, garante a todos os trabalhadores do setor público e do setor privado o direito de greve, dentro das condições estabelecidas em lei. ${ }^{210}$

O Paraguai também assegura na sua constituição o direito de greve aos servidores públicos. A Constituição Política da República do Paraguai, de 20 de junho de 1992, em seu artigo 98 afirma que todos os trabalhadores do setor público ou privado, com exceção dos membros das forças armadas da Nação e da polícia, têm o direito de recorrem à greve em caso de conflitos de interesse, sendo que a lei deverá regular o exercício desse direito para que não sejam afetados os serviços públicos imprescindíveis para a comunidade. ${ }^{211}$

Há países em que o direito de greve dos servidores públicos não está previsto expressamente no texto constitucional, mas de forma genérica como é o caso da Espanha, da França, da Itália, de Portugal, do Uruguai.

A Espanha é um caso que tem características especiais com relação ao direito de greve dos servidores públicos. ${ }^{212}$ A Constituição Espanhola de 27 de dezembro de 1978 trata a greve como direito fundamental, ao inserir o tema no Título I, Capítulo II, Seção $1^{\text {a }}$ relativa aos "direitos fundamentais e das liberdades públicas". O artigo 28.2 do texto constitucional "reconhece o direito de greve aos trabalhadores para defesa de seus interesses" e dispõe que "a lei que regule o exercício deste direito estabelecerá as garantias necessárias para assegurar a manutenção dos serviços essenciais da comunidade. ${ }^{213}$ No entanto, a Lei do Estatuto dos Trabalhadores dispõe no artigo 4.1-e que a greve é um dos direitos básicos dos trabalhadores, porém, o mesmo documento exclui do seu âmbito de aplicação os servidores públicos, conforme estabelece o seu artigo 1.3- $a .^{214}$

Diante dessa exclusão prevista no Estatuto dos Trabalhadores surgiu na doutrina e na jurisprudência espanhola um debate em torno do reconhecimento constitucional do direito de greve no setor público, tendo em vista que o termo 'trabalhadores' expresso na Constituição, assim como na lei trabalhista, não inclui os servidores públicos. O Tribunal Constitucional pronunciou-se no sentido de que "o eventual direito de greve dos

\footnotetext{
${ }^{210}$ CONSTITUCiÓN DE LA REPUBLICA BOLIVARIANA DE VENEZUELA. Disponível em: $<$ http://www.venezuela-oas.org/Constitucion\%20de\%20Venezuela.htm>. Acesso em: 08 nov. 2008.

${ }^{211}$ REPÚBLICA DE PARAGUAY. Constitución Política de 1992. Disponível em: $<$ http://pdba.georgetown.edu/Constitutions/Paraguay/para1992.html>. Acesso em: 08 nov. 2008.

${ }^{212}$ LÓPEZ-MONÍS DE CAVO, Carlos. op. cit., p. 97.

${ }^{213}$ CONSTITUCIÓN ESPAÑOLA. Disponível em: <http://www.senado.es/constitu/index.html>. Acesso em: 11 nov. 2008.

${ }^{214}$ MINISTERIO DE TRABAJO Y SEGURIDAD SOCIAL (BOE número 75 de 29/3/1995). Disponível em: $<$ http://www.boe.es/g/es/bases_datos/doc.php?coleccion=iberlex\&id=1995/07730>. Acesso em: 12 nov. 2008.
} 
funcionários públicos não está regulamentado e, por conseguinte, tampouco proibido" pela lei trabalhista. ${ }^{215} \mathrm{~A}$ indeterminação da aplicação do referido artigo constitucional aos servidores públicos, contudo, não resultou em um abalo do ponto de vista prático, pois "as greves dos funcionários são um fato, sem que sua realização tenha produzido efeitos jurídicos de especial importância contra os participantes das referidas ações". ${ }^{216}$

A Lei 30/1984, de 2 de agosto, que trata de medidas para a reforma da função pública, pode ser considerado o primeiro reconhecimento legislativo expresso e geral do ordenamento jurídico espanhol em relação ao direito de greve dos servidores públicos. ${ }^{217}$

No ordenamento jurídico francês o direito de greve está previsto no parágrafo $7^{\circ}$ do Preâmbulo da Constituição da República Francesa de 27 de outubro de 1946, mantido na atual Constituição de 04 de outubro de 1958. Tal dispositivo estabelece que "o direito de greve se exerce no âmbito das leis que o regulam". ${ }^{218}$

O Código do Trabalho francês no seu artigo L2511-1 reconhece o direito de greve ao dispor de forma geral que "a greve não interrompe o contrato coletivo de trabalho, salvo falta muito greve imputável ao assalariado". ${ }^{219}$ Os artigos L2512-1 e seguintes tratam, de forma específica, do direito de greve dos servidores públicos. ${ }^{220}$ Os dispositivos são aplicados ao pessoal civil que trabalha a serviço do Estado, dos Departamentos de dos Municípios com mais de 100 mil habitantes, bem como, às pessoas que prestam serviço às empresas, estabelecimentos, organismos públicos e privados, quando este estiver encarregado de gestão de um serviço público. Entre as exigências previstas nesta regulamentação está a necessidade de aviso prévio com antecedência mínima de cinco dias à autoridade hierárquica com a indicação dos motivos, do lugar, data e hora do início, a duração etc.

O artigo $57^{\circ}$ da Constituição da República Portuguesa, inserido no Capítulo III, Título II, Parte I, que trata dos Direitos e deveres fundamentais, garante o direito de greve de forma genérica aos trabalhadores, aos quais compete definir o âmbito de

\footnotetext{
${ }^{215}$ LÓPEZ-MONÍS DE CAVO, Carlos. op. cit., p. 97.

${ }^{216}$ Id. Ibid., p. 98.

${ }^{217}$ PALOMEQUE LÓPEZ, Manuel Carlos; ÁLVAREZ DE LA ROSA, Manuel. op. cit., p. 517.

${ }^{218}$ FRANCE. La Constitution - Préambule de la Constitution de 1946. Legifrance. Disponível em: $<$ http://www.legifrance.gouv.fr/html/constitution/const02.htm>. Acesso em: 12 nov. 2008.

${ }^{219} \mathrm{CODE}$ DU TRAVAIL. Legifrance. Disponível em: $<$ http://www.legifrance.gouv.fr/affichCode.do;jsessionid=8413501DAEEDA68595DAB9501AE2C0DC.tp djo04v_3?idSectionTA=LEGISCTA000006177988\&cidTexte=LEGITEXT000006072050\&dateTexte $=200$ 81112>. Acesso em: 12 nov. 2008.

${ }^{220}$ Id. Ibid.
} 
interesses a serem defendidos por meio dela e proíbe o lock-out. Também deixa a cargo da legislação infraconstitucional a definição quanto às condições de prestação, durante o período da greve, dos serviços necessários à segurança e manutenção de equipamentos e instalações, bem como, os serviços essenciais, entendidos como aqueles "serviços mínimos indispensáveis para ocorrer à satisfação de necessidades sociais impreteríveis". 221

O direito de greve dos servidores públicos no ordenamento português ainda é assegurado de modo explícito no artigo 12 da Lei nº7 de 26 de agosto de 1977, o qual estabelece que "é garantido o exercício do direito à greve na função pública" e também prevê que tal exercício será regulamentado em estatuto próprio ou diploma especial, sem que isso possa causar prejuízo ao direito de greve desses trabalhadores. ${ }^{222}$

A expressão "função pública" é utilizada no artigo mencionado anteriormente refere-se a "todas as espécies de funcionários e agentes administrativos, incluindo os da administração regional e local". ${ }^{223}$ No entanto, é importante ressaltar que estão excepcionados da aplicação deste dispositivo os membros das forças armadas e a polícia militar, conforme disposição do artigo $13^{\circ}$ da mesma lei. ${ }^{224}$

A Constituição da República uruguaia prevê o direito de greve na parte final do seu artigo 57, que trata do tema de forma geral ao declarar apenas que a greve é um direito gremial e afirma que sobre essa base se regulamentará o seu exercício e a sua efetividade. $^{225}$

Outro importante exemplo de país que reconhece o direito de greve aos servidores públicos é a Itália. O caso italiano, no entanto, será estudado em separado em razão da necessidade de aprofundamento do tema, uma vez que este país pode ser considerado um modelo no trato das relações coletivas de trabalho em geral e da greve em particular.

\footnotetext{
${ }^{221}$ CONSTITUIÇÃO DA REPÚBLICA PORTUGUESA. Disponível em: <http://www.parlamento.pt/Legislacao/Paginas/ConstituicaoRepublicaPortuguesa.aspx\#art57>. Acesso em: 07 nov. 2008.

${ }^{222}$ FERNANDES, António Monteiro. Direito de greve: notas e comentários à lei no 65/77, de 26 de agosto. Coimbra: Almedina, 1982. p. 73.

${ }^{223}$ Id., loc. cit.

${ }^{224}$ Id. Ibid., p. 75.

${ }^{225}$ CONSTITUCIÓN DA REPÚBLICA ORIENTAL DEL URUGUAY. Disponível em: <http://www.parlamento.gub.uy/constituciones/const004.htm>. Acesso em: 21 jan. 2009.
} 


\subsubsection{Itália}

No ordenamento jurídico italiano é reconhecido aos trabalhadores o direito de greve, que constitui a forma mais incisiva de autotutela dos interesses coletivos dos trabalhadores, entendida como uma manifestação essencial e originária da coalizão sindical. $^{226}$

A Constituição Italiana de 1948 reconhece o direito de greve em seu artigo 40, que estabelece de forma geral, tanto para o setor privado quando para o serviço público, que "o direito de greve se exercita no âmbito das leis que o regulam”. ${ }^{227}$

Sob esta norma, o recurso à greve é difundido paralelamente ao fenômeno da sindicalização, que serve de matriz também em relação aos subordinados públicos (pubblici dipendenti) e aos encarregados de serviços públicos (addetti a pubblici servizi). Os primeiros são aqueles que realizam tarefas de interesse geral dos cidadãos nas repartições públicas, enquanto os segundos são aqueles que desempenham, na maioria das vezes, a satisfação das necessidades essenciais dos usuários. ${ }^{228}$

A demora na aprovação de uma lei que regulasse, segundo os mandamentos constitucionais, o direito de greve na Itália promoveu um vasto e criativo trabalho, tanto da doutrina como da jurisprudência, a respeito do tema. ${ }^{229}$

A doutrina italiana faz uma distinção entre limite interno e limite externo do direito de greve. Este é derivado da necessidade de coordenar o reconhecimento do direito de greve com outros direitos que também gozam da proteção dada pela constituição, enquanto aquele resulta do próprio conceito do direito de greve. ${ }^{230}$

O limite externo ao direito de greve ganha relevância, sobretudo, quando se trata da greve dos encarregados de serviço público, porque "a greve de tais trabalhadores poderiam por em perigo bens fundamentais do ordenamento, como a vida e a integridade físico-

\footnotetext{
${ }^{226}$ GIUGNI, Gino. op. cit., p. 213.

${ }^{227}$ COSTITUZIONE DELLA REPUBBLICA ITALIANA. Disponível em: $<$ http://www.cortecostituzionale.it/istituzione/lacorte/fontinormative/lacostituzione/costituzione_parte_i.asp >. Acesso em 15 jan. 2009.

${ }^{228}$ SCOGNAMIGLIO, Renato. Diritto del lavoro. 5. ed. Napoli: Editrice Dott. Eugenio Jovene, 2000. p. 400.

${ }^{229}$ GALANTINO, Luisa. Dirito sindacale. 4. ed. Torino: G. Giappichelli, 2006. p. 195.

${ }^{230}$ GIUGNI, Gino. op. cit., p. 230.
} 
psíquica dos indivíduos, a segurança dos bens, o direito de liberdade dos cidadãos e a segurança nacional". 231

A Constituição de 1948 não tem um dispositivo no qual prevê de forma direta a negociação coletiva no setor público, nem mesmo faz referência indireta quando trata da liberdade sindical e da greve. O artigo 97 estabelece que "os serviços públicos são organizados segundo disposição legal, de modo que sejam assegurados o bom andamento e a imparcialidade da administração". ${ }^{232}$ Robertônio Santos Pessoa adverte que o texto constitucional "impõe limites à negociação coletiva, ao estabelecer a reserva legal para a disciplina das matérias referentes à administração pública. Contudo, predomina hoje o entendimento de que tal reserva não é absoluta". ${ }^{233}$

O primeiro reconhecimento da negociação coletiva no serviço público na Itália se deu com a Lei n. 192, de 12 de fevereiro de 1968, que reformou o setor de hospitais. ${ }^{234} \mathrm{Em}$ seguida, foram elaboradas diversas leis que regulavam o direito de negociação coletiva em setores determinados da administração pública. Posteriormente, entra em vigor a Lei n. 93 em 1983, chamada Lei Quadro para o Emprego Público, que uniformizou a disciplina contratual no setor público ${ }^{235}$.

De acordo com o artigo $4^{\circ}$, os objetivos a serem perseguidos pela Lei Quadro são: a homogeneização das posições jurídicas; a equiparação e a transparência dos tratamentos econômicos; a eficiência administrativa. ${ }^{236}$

A Lei Quadro, conforme prevê o artigo 26, tem uma abrangência ampla quanto às pessoas de direito público, no entanto, ela não se aplica a certas categorias de agentes públicos, entre os quais, os magistrados, o pessoal de carreira diplomática, a polícia e os advogados e procuradores do Estado. ${ }^{237}$

A negociação coletiva é realizada, conforme estabelece o artigo $6^{\mathrm{a}}$ da lei, entre uma delegação da administração pública e uma delegação sindical, composta pelos

\footnotetext{
${ }^{231}$ GALANTINO, Luisa. op. cit., p. 206.

${ }^{232}$ COSTITUZIONE DELLA REPUBBLICA ITALIANA, cit.

${ }^{233}$ PESSOA, Robertônio Santos. op. cit., p. 102.

${ }^{234}$ Id., loc. cit.

${ }^{235}$ DE LUCA, Carlos Moreira. A negociação coletiva no serviço público. In: SOARES, José Ronald Cavalcante (Coord.). O servidor público e a Justiça do Trabalho: homenagem ao Ministro Ronaldo José Lopes Leal. São Paulo: LTr, 2005. p. 54.

${ }^{236}$ LEGGE Quadro sul pubblico impiego. Legge 29 marzo 1983 n.93. Disponível em: $<$ http://www.normeinrete.it/cgi-

bin/StampaFrameURN?URL=http://www.italgiure.giustizia.it/nir/1983/lexs_101796.html>. Acesso em 16 jan. 2009.

${ }^{237}$ Id. Ibid.
} 
representantes das organizações nacionais de maior representatividade em cada unidade de negociação e por representantes das confederações mais representativas em âmbito nacional. Entre as condições para a admissão da organização sindical na negociação coletiva, esta a que ela tenha adotado um código de auto-regulação do direito de greve, conforme prevê o artigo 11 da mesma lei. Sendo assim, procurou-se "encontrar um equilíbrio entre o interesse público e a autonomia coletiva, sendo os códigos expressão desta última," ${ }^{238}$ O primeiro é resguardado "sem imposição de lei, regulando o exercício do direito de greve, ao que tradicionalmente se opõem os sindicatos". 239

A Lei Quadro propiciou “a ocorrência de uma transformação fundamental no direito italiano: a passagem de uma negociação informal a uma negociação institucionalizada, ou seja, inteiramente regulada e sob controle central. As partes, alcance e duração dos acordos encontram-se agora criteriosamente disciplinados em lei, enquanto as políticas de salários se travam a nível central”. ${ }^{240}$

A Lei n. 146 de 12 de junho de 1990 trata das normas a respeito do direito de greve nos serviços públicos essenciais e sobre a salvaguarda dos direitos constitucionalmente tutelados e foi alterada pela Lei n.83 de 11 de abril de 2000 .

Antes da promulgação da Lei n. 146 de 1990, a jurisprudência desenvolveu um extenso e criativo trabalho a respeito do tema. A Corte Constitucional Italiana pronunciou uma série de decisões, ao longo de pouco mais de quarenta anos entre a Constituição e a referida lei, relativas ao direito de greve dos servidores públicos. ${ }^{241}$

Da análise dessas sentenças proferidas pela Corte Constitucional é possível identificar o princípio segundo o qual o direito de greve dos trabalhadores do setor privado e do setor público deve salvaguardar o núcleo dos interesses gerais também tutelados constitucionalmente como o direito à vida, à saúde, a integridade física etc. Os servidores públicos que trabalham nos serviços essenciais, que a princípio eram excluídos da titularidade do direito de greve pela jurisprudência, passaram a lograr de tal direito, pois, posteriormente, altera-se o entendimento no sentido de manter a titularidade desse direito a essa espécie dos trabalhadores, porém submetido o seu exercício a limites. ${ }^{242}$

\footnotetext{
${ }^{238}$ PESSOA, Robertônio Santos. op. cit., p. 104.

${ }^{239}$ DE LUCA, Carlos Moreira. op. cit., p. 56.

${ }^{240}$ PESSOA, Robertônio Santos. op. cit., p. 104-105.

${ }^{241}$ GALANTINO, Luisa. op. cit., p. 205.

${ }^{242}$ Id. Ibid., p. 206-207.
} 
A Lei n. 149 de 1990 foi formulada com base "na proposta da Federação sindical unitária, ante o reconhecimento da insuficiência dos códigos de auto-regulação das greves no serviço público, para assegurar a manutenção dos serviços essenciais à população". 243

O artigo $1^{\circ}$ da Lei n. 146 de 1990 apresenta um rol de serviços públicos essenciais, que são direitos constitucionalmente tutelados, entre os quais estão: o direito à vida, o direito à saúde, o direito à liberdade e à segurança, o direito à liberdade de circulação, o direito à assistência e à previdência social, o direito à educação, o direito da liberdade de comunicação. ${ }^{244}$ Estes direitos tutelados constitucionalmente e que figuram como serviços essenciais nesta lei constituem um rol taxativo, caso contrário, seria possível derrogar a reserva estabelecida em matéria de greve pelo artigo 40 da Constituição italiana. ${ }^{245}$ É importante lembrar que os serviços públicos essenciais acima identificados independem da natureza da relação de trabalho à que estão vinculados, isso significa que a lei se aplica àqueles serviços oferecidos diretamente pelo poder publico e àqueles geridos por meio de relações contratuais de direitos privado.

Antes da proclamação da greve, as partes devem obrigatoriamente tentarem a conciliação em sede administrativa e, depois disso, a greve é considerada legítima e deve respeitar alguns requisitos, entre os quais estão: (i) pré-aviso mínimo de dez dias; (ii) prévia comunicação escrita da duração, da modalidade de atuação e a motivação da abstenção coletiva de trabalho; (iii) especificação das prestações indispensáveis. O tempo requerido no primeiro requisito tem o propósito de possibilitar a viabilização de meios para as prestações indispensáveis, além de favorecer o desenvolvimento de uma eventual tentativa de composição do conflito e, finalmente, permitir aos usuários dos serviços públicos usufruírem de serviços alternativos. O comunicado escrito deve ser dirigido à administração pública ou prestadora do serviço público para que o transmita à Comissão de $\operatorname{Garantia}^{246}$. A especificação das prestações indispensáveis é fixada na contratação coletiva. $^{247}$

\footnotetext{
${ }^{243}$ DE LUCA, Carlos Moreira. op. cit., p. 57.

${ }^{244}$ LEGGE 12 giugno 1990, n. 146. Disponível em: <http://www.normeinrete.it/cgibin/StampaFrameURN?URL=http://www.italgiure.giustizia.it/nir/1990/lexs_126933.html>. Acesso em 15 jan. 2009.

${ }^{245}$ GALANTINO, Luisa. op. cit., p. 207.

${ }^{246}$ A Comissão de Garantia é um órgão composto de nove membros, nomeados pelo Presidente da República por três anos e podendo ser reconduzidos apenas uma vez. A indicação é feita pelos presidentes das duas Câmaras - dos Deputados e do Senado - entre os especialistas em direito constitucional, do trabalho e relações industriais, não ligados a entidades profissionais ou econômicas, ou partidos políticos.

${ }^{247}$ GALANTINO, Luisa. op. cit., p. 208-209.
} 
Quanto a este último requisito, não podemos deixar de registrar que esta tarefa não é fácil contemporizar, como ressalta Giuseppe Pera, que ainda observa que "a greve não pode tornar-se inútil na sua capacidade ofensiva, mas não pode por em perigo os bens considerados (...) este capítulo é muito controverso, sobretudo, porque, em diversas situações, não é possível estabelecer sindicalmente as prestações indispensáveis". ${ }^{248}$

$\mathrm{O}$ autor defende que, pelo menos a princípio, a lei não prevê uma intervenção autoritária para a determinação das prestações indispensáveis, não podendo ser considerada excessivamente lesiva à autonomia sindical, pois as partes envolvidas é que, mediante acordo, decidem. Além disso, as prestações indispensáveis, por sua vez, exigem apenas a cota estritamente necessária de trabalhadores para mantê-las. ${ }^{249}$

Evidentemente, a solução convencionada entre as partes em conflito para determinação das prestações indispensáveis não é fácil de ser obtida na prática. A Comissão de Garantia pode ser chamada para atuar de várias formas, entre as quais, avaliar a idoneidade das determinações convencionadas. Caso ela repute que as determinações são insuficientes, pode fazer propostas, fazer tentativas de conciliação, se pronunciar, mediante pedido em conjunto das partes, em um laudo. Ela pode exprimir o seu próprio juízo sobre as questões interpretativas, avaliar o comportamento das partes, fazer relatos periodicamente aos presidentes das Câmaras dos Deputados e do Senado. ${ }^{250}$ A Comissão de Garantia não tem poder decisório e colabora para o bom andamento das relações sindicais no serviço público, acompanhando as negociações e a efetiva manutenção das atividades essências. $^{251}$

Quanto à inobservância dos preceitos previstos na lei de greve italiana, Giuseppe Pera adverte que em uma democracia livre é extremamente difícil socorrer-se de um aparato repressivo quando se trata de um fenômeno de massa. Sendo assim, reconhece o autor que a lei em questão não se excedeu nas sanções que se limitam a multas pecuniárias e suspensão, mesmo por que o artigo do Código Rocco de 1930 que punia a greve nos serviços considerados foi abolido. ${ }^{252}$

\footnotetext{
${ }^{248}$ PERA, Giuseppe. Compendio de diritto del lavoro. 5. ed. Milano: Giuffrè, 2000. p. 93.

${ }^{249}$ Id. Ibid., p. 94.

${ }^{250}$ Id. Ibid., p. 95.

${ }^{251}$ DE LUCA, Carlos Moreira. op. cit., p. 59.

${ }^{252}$ PERA, Giuseppe. op. cit., p. 95.
} 


\subsection{Direito brasileiro}

O direito de greve dos servidores públicos está previsto na Constituição Federal, no entanto, o exercício desse direito enfrenta uma série de dificuldades do ponto de vista jurídico em função de divergências sobre da matéria. Muito embora, no mundo real elas continuem acontecendo, cada vez em maior número e em situações que afligem a todos enquanto usuários dos serviços públicos.

Assevera Wagner D. Giglio que "no regime anterior ao da atual Constituição as greves no serviço público eram proibidas, e apesar da proibição as greves eclodiam. E continuam a surgir greves no serviço público, apesar da falta de embasamento legal. Diante da total inexistência desta, ou de outra solução legal, a greve continua sendo a única forma de sensibilizar a administração e dela obter alguma melhoria das condições de trabalho, ainda que a resistência dos órgãos governamentais não propicie soluções satisfatórias". ${ }^{253}$

A Organização Internacional do Trabalho no Relatório de 1970 assinalava "que as estatísticas relativas à frequiência das greves na administração pública não têm necessária correlação com a questão da legalidade ou ilegalidade ou ilegitimidade da mesma. As suspensões de trabalho na administração pública têm sido freqüentes em países onde a greve é proibida e, comparativamente, excepcionais nos países que a aceitam". ${ }^{254}$

A questão não é muito simples, pois envolve dois ramos do Direito, aparentemente, bastante diversos, sobretudo, quanto a sua natureza jurídica. De um lado está o direito administrativo, classificado como ramo do direito público, e de outro, o direito do trabalho, hoje, sem qualquer dúvida, ramo do direto privado. Na confluência deles está o direito de greve do servidor público. Esse pode ser considerado o elemento que causa dificuldade e que provoca, portanto, a divergência de posicionamentos.

Por isso, o estudo do direito de greve do servidor público exige uma atenção especial no que diz respeito não só aos princípios do direito administrativo, mas também em relação aos princípios do direito de trabalho, mormente, do direito coletivo do trabalho.

O direito de greve, neste caso, muito embora seja um instituto típico do direito coletivo do trabalho, não pode ser estudado isoladamente sob uma perspectiva publicista

\footnotetext{
${ }^{253}$ GIGLIO, Wagner D. Brasil: trabajadores del Estado em Iberoamerica. Mario Ackerman (Coord.). Buenos Aires: Ediciones Ciudad Argentina. 1998. p. 67.

${ }^{254}$ LÓPEZ-MONÍS DE CAVO, Carlos. op. cit., p. 27-28.
} 
ou privatistica. Também não é possível a sua simples transposição ao servidor público, sem serem levados em consideração outros institutos do direito coletivo do trabalho, como o direito de sindicalização e o direito de negociação coletiva de trabalho, sob pena de desnaturação do próprio direito de greve.

Os servidores públicos, apesar das suas especificidades, também são trabalhadores e precisam ser ouvidos e, para tanto, precisam dispor de uma arma de defesa dos seus interesses. Como adverte Dalmo de Abreu Dallari, "trabalhador é quem trabalha e o trabalhador assalariado, não importa quem pague, é trabalhador assalariado e recebe, seja do setor público, seja da empresa privada" ${ }^{255}$ o numerário que será indispensável para a manutenção das condições básicas da sua própria vida e de seus familiares.

O direito de greve é a forma, por excelência, que os trabalhadores dispõem para pressionar e empregador ao menos para sentar-se à mesa de negociações. No entanto, de nada valerá essa arma se não estiver acompanhada de munição adequada, que são o direito de sindicalização livre, assim como, o direito de negociação coletiva.

É importante observar que a greve é, antes de qualquer coisa, um fato social. Sendo assim, independentemente do tratamento jurídico que lhe for atribuído ela continuará a existir, a não ser que os conflitos desapareçam, o que é improvável. Sendo assim, é importante que seja dado um tratamento adequado ao direito de greve dos servidores públicos, para que ele possa efetivamente existir. Os posicionamentos que inviabilizavam desde logo esse direito, em nada contribuem para alcançar o que eles mesmos defendem que a preservação do interesse público.

Antes de prosseguirmos na discussão do tema em destaque, faz-se necessário tecermos algumas considerações acerca da terminologia que circunscreve estes trabalhadores do setor público.

\subsubsection{Servidores públicos: terminologia}

Como já é sabido, o presente estudo pretende examinar o direito de greve do servidor público. Isso exige que, antes de qualquer aprofundamento, seja traçado o

\footnotetext{
${ }^{255}$ DALLARI, Dalmo de Abreu. Direito de greve. In: LOUREIRO, Isabel; DEL-MASSO, Maria Cândida Soares. Tempos de greve na Universidade Pública. Marília: Unesp-Marília-Publicações; São Paulo: Cultura Acadêmica, 2002. p. 195.
} 
significado da expressão "servidor público" que estamos adotando nele, assim como, sejam analisados os termos correlatos. A legislação brasileira e a doutrina empregam uma diversidade de expressões, em razão disso, passaremos a investigá-las, a fim de esclarecermos melhor o tema.

José Cretella Junior, ao investigar a natureza jurídica da função pública, deparouse com a necessidade de esclarecer o significado das expressões "funcionário público" e "função pública", pois, como bem observa o autor, do emprego preciso dos termos e expressões temos como resultado a melhor e mais célere compreensão das idéias. ${ }^{256}$

A palavra função indica, segundo o autor, qualquer atividade exercida por órgão para consecução de um fim, sendo que a função será pública, caso esse fim visado diga respeito aos interesses da coletividade. Ele define função pública como "toda atividade praticada por agente, funcionário ou não, para a consecução de um fim de interesse da coletividade". ${ }^{257}$

A função pública abrange não só aqueles que exercem uma função administrativa, mas também aqueles que exercem funções legislativas e jurisdicionais. Existem, também, pessoas que exercem função pública, no entanto, sem que haja vínculo de natureza empregatícia com o Estado.

Em razão disso, usa-se a denominação "agentes públicos”, mais abrangente que servidores públicos, pois na verdade esta expressão "é a mais ampla que se pode conceber para designar genérica e indistintamente os sujeitos que servem ao Poder Público como instrumentos expressivos de sua vontade ou ação, ainda quando o façam ocasional ou episodicamente". 258

Agente público então é gênero, cujas espécies são: agentes políticos; servidores estatais, incluindo servidores públicos e servidores das pessoas governamentais de direito privado, e particulares em colaboração com o Estado. ${ }^{259}$

Bandeira de Mello ensina que os "agentes políticos são os titulares dos cargos estruturais à organização política do País, isto é, são os ocupantes dos cargos que compõem o arcabouço constitucional do Estado e, portanto, o esquema fundamental do poder. Sua

\footnotetext{
${ }^{256}$ CRETELLA JUNIOR, José. Natureza jurídica da função pública. 1953. Dissertação (Livre docência) Faculdade de Direito, Universidade de São Paulo, São Paulo, 1953. p. 15.

${ }^{257}$ Id. Ibid., p. 18-19.

${ }^{258}$ MELLO, Celso Antônio Bandeira de. Curso de direito administrativo. 14. ed.São Paulo: Malheiros Ed., 2002. p. 219.

${ }^{259}$ Id. Ibid., p. 222.
} 
função é a de formadores da vontade superior do Estado. São agentes políticos o Presidente da República, os Governadores, os Prefeitos e respectivos auxiliares imediatos (ministros e secretários das diversas pastas), os Senadores, os Deputados e Vereadores. Todos estes se ligam ao Estado por um liame não profissional. A relação que os vincula aos órgãos do poder é de natureza política. Desempenham um múnus público (...) são titulares de direitos e de responsabilidades na condução da res publica". ${ }^{260}$ Hely Lopes Meirelles inclui nessa categoria também os membros da Magistratura, do Ministério Público, Tribunais de Constas, representantes diplomáticos. ${ }^{261}$ Os agentes políticos, entendidos desta forma ampla, detém ou recebem do Estado parcela da sua soberania para agir em seu nome, por isso não poderia ostentar o direito de greve, já que constitui, em essência, o próprio Estado. Seria o mesmo que dizer, por analogia, que seriam os diretores de uma empresa, e como tal, não seria lógico, nem razoável, a diretoria entrar em greve já que constitui o cérebro da organização, que detém o poder de mando e de decisão.

A denominação "servidores públicos”, por sua vez, designa uma espécie do gênero "servidores estatais". Enquanto estes englobam todos os que mantêm com o Estado e suas entidades da Administração indireta, de natureza pública ou privada, relação de natureza profissional e caráter não eventual sob vínculo de dependência, aqueles são os integrantes de cargo ou emprego nas pessoas jurídicas de direito público. ${ }^{262}$

A Constituição de 1988, como observa Edmir Netto de Araújo, é, entre as constituições brasileiras, a que tratou a matéria dos servidores públicos de forma mais imprecisa, principalmente, devido à falta de uniformidade de nomenclatura, à contradição entre conceitos e à imperfeição da redação. ${ }^{263}$ Esse quadro foi agravado com as alterações implementadas pelas emendas constitucionais que se sucederam, principalmente, as Emendas Constitucionais n. 19/98, n. 20/98, n. 41/03 e n. 47/05.

Para Maria Sylvia Zanella Di Pietro, a Constituição Federal emprega a terminologia "servidores públicos" tanto em sentido lato como em sentido menos amplo. ${ }^{264}$ No primeiro caso, entende-se que servidor público é a pessoa física que presta serviço para o Estado ou para entidades da Administração Indireta, com vínculo empregatício. No

\footnotetext{
${ }^{260}$ MELLO, Celso Antônio Bandeira de. Regime Constitucional dos servidores da administração direta e indireta. São Paulo: Ed. Revista dos Tribunais, 1990. p. 8-9.

${ }^{261}$ MEIRELLES, Hely Lopes. Direito administrativo brasileiro. 20. ed. São Paulo: Malheiros Ed., 1995. p. 74.

${ }^{262}$ MELLO, Celso Antônio Bandeira de. Curso de direito administrativo, cit., p. 223.

${ }^{263}$ ARAÚJO, Edmir Netto de. Curso de direito administrativo. 2. ed. São Paulo: Saraiva, 2006. p. 270.

${ }^{264}$ DI PIETRO, Maria Sylvia Zanella. Direito administrativo. 13. ed. São Paulo: Atlas, 2001. p. 421.
} 
sentido menos amplo, a expressão em tela exclui aqueles que prestam serviços às entidades com personalidade jurídica de direito privado.

A falta de uniformidade na terminologia usada pela Constituição se reflete também na doutrina, uma vez que é possível identificar os mais diversos significados da expressão servidor público. ${ }^{265}$ Celso Antônio Bandeira de Mello extrai do texto constitucional que servidores públicos são "todos aqueles que mantêm vínculos de trabalho profissional com as entidades governamentais, integrados em cargos ou empregos da União, Estados, Distrito Federal, Municípios, respectivas autarquias e fundações de Direito Privado". ${ }^{266}$ Odete Medaur, por sua vez, afirma que, na constituição vigente, a expressão servidores públicos "designa todas as pessoas físicas que trabalham nos entes estatais, de qualquer poder, inclusive os detentores de cargos". 267

O texto constitucional, na seção II do capítulo relativo à Administração Pública, usa a expressão "servidores públicos civis" para designar aqueles que prestam serviço, com vínculo empregatício, à Administração Pública direta, autarquias e fundações públicas.

Já na seção I do mesmo capítulo do texto constitucional é empregada a expressão servidor público em sentido amplo, uma vez que trata daqueles que prestam serviços à administração pública direta, indireta e fundacional. Isso inclui, como observa Maria Sylvia Zanella Di Pietro ${ }^{268}$, além das autarquias e fundações públicas, as empresas públicas, as sociedades de economia mista e fundações de direito privado.

Em sua dissertação de livre docência, José Crelella Junior aponta os elementos extrínsecos com que a função pública se apresenta na prática. Entre estes elementos figura: a personalidade dominante do Estado, no exercício do jus imperii; a pessoa física do indivíduo que executa serviços de interesse coletivo; a remuneração, quando existe, em retribuição aos serviços prestados; a vontade livre para a execução do serviço; a existência de uma relação, entre o indivíduo que executa a função pública e o Estado, que produz obrigações recíprocas e de especiais conseqüências. ${ }^{269}$

Para efeito desse trabalho, muito embora a expressão servidor público possa alcançar um significado muito mais amplo como já foi demonstrado, ela será usada de

\footnotetext{
${ }^{265}$ ARAÚJO, Edmir Netto de. op. cit., p. 270.

${ }^{266}$ MELLO, Celso Antônio Bandeira de. Curso de direito administrativo, cit., p. 224.

${ }^{267}$ MEDAUAR, Odete. Direito administrativo moderno. 9. ed. São Paulo: Ed. Revista dos Tribunais, 2006. p. 261.

${ }^{268}$ DI PIETRO, Maria Sylvia Zanella. op. cit., p. 421.

${ }^{269}$ CRETELLA JUNIOR, José. op. cit., p. 22-23.
} 
forma restrita a identificar apenas aquele que exerce função pública em troca de remuneração para os entes de direito público, pois a greve para aqueles que trabalham nos entes públicos de direito privado, como as empresas de economia mista, as sociedades de economia mista e as suas subsidiárias estão sujeitos ao regime das empresas do setor privado, inclusive, em relação às disposições da Lei n. 7.783 de 1989 que regula a greve.

\subsubsection{Institutos interligados}

A sindicalização, a negociação coletiva e a greve são institutos próprios do direito do trabalho e o servidor público tem tido um tratamento de regime institucional do direito administrativo. A transposição parcial de institutos do direito coletivo do trabalho como o reconhecimento do direito de greve para o serviço público, sem que seja levada em consideração a negociação coletiva pode acarretar problemas que interferem na efetividade do direito de greve. Não há dúvida que o serviço público tem características singulares que devem ser levadas em consideração e que, por isso, precisam de um tratamento diferenciado, mas isso não significa uma diferenciação que mascare um aniquilamento desse direito.

O direito de sindicalização, sem que esteja acompanhado do direito de greve e de negociação coletiva fica restringido, uma vez que as funções do sindicato ficam bastante prejudicadas. Mesmo porque, "ao sindicato devem ser garantidos os meios para o desenvolvimento da sua ação destinada a atingir os fins para os quais foi constituído. De nada adiantaria a lei garantir a existência de sindicatos e negar os meios para que as suas funções pudessem ser cumpridas". 270

A greve e a negociação coletiva são meios indispensáveis para o cumprimento dos seus fins, visto que uma das principais funções do sindicato, para não dizer a mais importante, é a negocial. Por isso, podemos afirmar que sem eles a atividade sindical fica praticamente relegada à recreação associativa ou, no máximo, à função assistencialista.

O direito de sindicalização e de greve, desacompanhados do direito de negociação coletiva, também não traz os resultados esperados, influindo na própria efetividade do direito de greve. Em razão disso, a exemplo do que foi feito no primeiro capítulo,

\footnotetext{
${ }^{270}$ NASCIMENTO, Amauri Mascaro. Compêndio de direito sindical, cit., p. 252-253.
} 
trataremos dos institutos interligados ao direito de greve - sindicalização e negociação coletiva - também sob a ótica dos servidores públicos.

\subsubsection{Sindicalização dos servidores públicos}

Geraldo von Potobsky afirma a necessidade de se tratar do tema sindicalização no setor público em qualquer estudo que pretenda tratar de relações coletivas de trabalho, mormente na América Latina. O autor assegura que o sindicalismo no setor público ganha relevância, sobretudo, "frente ao contínuo crescimento do emprego público e à proliferação dos serviços e empresas do Estado na região". E complementa observando que "torna-se especialmente importante o problema das condições de trabalho neste setor e a participação dos funcionários e de outros trabalhadores estatais na determinação destas condições através de seus representantes e, em particular, de suas organizações". 271

Houve um acentuado crescimento, em quase todo o mundo, nas atividades públicas e com isso a expansão no número de servidores nas décadas de sessenta e setenta. Entre as razões que explicam tal fenômeno podemos citar: (i) a expansão das funções de governo como provedor de serviços de utilidade pública e bem-estar social, mormente, educação e atendimento médico; (ii) ampliação do serviço público em muitos países que gozam de uma relativa prosperidade econômica; (iii) decisão por parte de alguns países de investimento em determinados setores da administração pública como estratégia nacional de desenvolvimento. ${ }^{272}$

A presença da sindicalização no setor público era considerada de forma diversa daquela que era aceita no setor privado por volta de quarenta anos atrás. As condições de trabalho dos servidores do Estado e dos entes públicos eram ditadas unilateralmente, por esta razão se dizia que não havia espaço para o sindicalismo neste setor, assim como, para o direito de greve, frente à superioridade do interesse público contraposto ao interesse de classe. $^{273}$

\footnotetext{
${ }^{271}$ POTOBSKY, Geraldo von. As organizações sindicais. In: CÓRDOVA, Éfren (Dir.). As relações coletivas de trabalho na América Latina: um estudo de seus atores, suas diversas manifestações e seus conflitos, com especial referência ao setor privado. Ttradução de Maria Luiza Jacobson. São Paulo: LTr; Genebra: Organização Internacional do Trabalho, 1985. p. 60.

${ }^{272}$ OZAKI, M. Las relaciones de trabajo em la administración pública: 1. Métodos de determinación de las condiciones de empleo. Revista Internacional del Trabajo, Genebra, v. 106, n. 3, p. 304, jul./sep. 1987.

${ }^{273}$ PERA, Giuseppe. Diritto del lavoro. 5. ed., Padova: CEDAM, 1996. p. 263.
} 
Apesar de muitos países terem negado aos servidores públicos o direito de constituir sindicatos, isso não impediu que existissem organizações dos trabalhadores desse setor, pois, "as mesmas são constituídas de fato ou conforme as disposições do direito civil (nominalmente para fins mutualistas, culturais etc), mas atuam como verdadeiros sindicatos para a defesa dos interesses profissionais de seus filiados. Organizações importantes de trabalhadores do Estado ou municipais e de grupos específicos, como professores ou empregados da área de saúde, de bancos oficiais ou de caixas de previdência, existem qualquer que seja o regime legal vigente. Criou-se, assim, uma situação paradoxal, em que o Estado legislador repudia e até negocia com eles." 274

É importante observar que, "o desconhecimento impune da legalidade é prejudicial para toda ordem jurídica. Em troca, se a realidade faz cair em desuso normas extemporâneas, é do interesse geral conciliar o plano jurídico com os fenômenos sociais que este deve regular. Isto não se aplica apenas ao reconhecimento do direito de sindicalização dos funcionários e de outros trabalhadores do Estado, mas também ao conjunto das relações coletivas de trabalho no setor público. As situações conflitivas mal canalizadas e as reivindicações frustradas pela falta de uma participação institucionalizada, não apenas desorganizam a administração do Estado, como corroem o processo econômico e afetam a comunidade". ${ }^{275}$

O direito de sindicalização dos servidores públicos é reconhecido em muitos países, no entanto, determinadas categorias de servidores, entre eles, os membros das forças armadas, a polícia, a magistratura, costumam ser excluídos desse direito. Em alguns países o direito de sindicalização é expresso no texto constitucional ou legal, mas também há países nos quais simplesmente ocorre a falta de uma proibição específica. ${ }^{276}$

Mas não podemos esquecer que "a sindicalização em grande escala dos servidores públicos é um fenômeno relativamente recente, em comparação com a larga tradição sindicalista no setor privado, ao menos na maioria dos países industrializados; (...) a filiação sindical cresceu rapidamente entre os servidores públicos nas décadas de 1960 e 1970 ". 277

No Brasil, antes da Constituição de 1988, a CLT, no caput do artigo 566, proibiase a sindicalização aos servidores do Estado e das instituições paraestatais. No entanto,

\footnotetext{
${ }^{274}$ POTOBSKY, Geraldo von. As organizações sindicais, cit., p. 62-63.

${ }^{275}$ Id. Ibid., p. 63.

${ }^{276}$ OZAKI, M. op. cit., p. 305.

${ }^{277}$ Id. Ibid., p. 307.
} 
ficavam excluídos desta restrição os servidores de sociedade de economia mista, fundações públicas e, por força de decisões judiciais, os servidores autárquicos regidos pela CLT. ${ }^{278}$ O parágrafo único deste artigo, com redação dada pela Lei 7.449 de1985, determina que: "excluem-se da proibição constante deste artigo os empregados das sociedades de economia mista, da Caixa Econômica Federal e das fundações criadas ou mantidas pelo Poder Público da União, dos Estados e Municípios".

A Constituição Federal de 1988, em seu artigo $5^{\circ}$, inciso XVII, garante a plena liberdade de associação para fins lícitos, vedada a de caráter paramilitar. A Lei n. 8.112 de 1990, em seu artigo 117, inciso VII, proíbe ao servidor público coagir ou aliciar subordinados no sentido de filiarem-se a associação profissional ou sindical, ou a partido político.

Quanto ao servidor público civil a Constituição Federal estabelece a liberdade da sindicalização nos seguintes termos:

"Art. 37. A administração pública direta e indireta de qualquer dos Poderes da União, dos Estados, do Distrito Federal e dos Municípios obedecerá aos princípios de legalidade, impessoalidade, moralidade, publicidade e eficiência e, também, ao seguinte: (Redação dada pela Emenda Constitucional no 19, de 1998) (.....)

VI - é garantido ao servidor público civil o direito à livre associação sindical;",279

No entanto, no que diz respeito ao servidor público militar, o texto constitucional veda tal direito.

\footnotetext{
"Art. 142. As Forças Armadas, constituídas pela Marinha, pelo Exército e pela Aeronáutica, são instituições nacionais permanentes e regulares, organizadas com base na hierarquia e na disciplina, sob a autoridade suprema do Presidente da República, e destinam-se à defesa da Pátria, à garantia dos poderes constitucionais e, por iniciativa de qualquer destes, da lei e da ordem. (...)

$\S 3^{\circ}$ Os membros das Forças Armadas são denominados militares, aplicando-se-lhes, além das que vierem a ser fixadas em lei, as seguintes disposições: (...)

IV - ao militar são proibidas a sindicalização e a greve; (Incluído pela Emenda Constitucional $n^{\circ} 18$, de 1998,"280
}

\footnotetext{
${ }^{278}$ BARROS, Alice Monteiro. Curso de direito do trabalho. 2. ed. São Paulo: LTr, 2006. p. 1208.

${ }^{279}$ CONSTITUIÇÃO DA REPÚBLICA FEDERATIVA DO BRASIL DE 1988. Disponível em: <http://www.planalto.gov.br/ccivil_03/Constituicao/Constitui\%C3\%A7ao.htm>. Acesso em: 15 jan. 2009.

${ }^{280}$ Id. Ibid.
} 


\subsubsection{Negociação coletiva dos servidores públicos}

A negociação coletiva era negada ao servidor público em virtude da dificuldade do Estado de negociar, uma vez que o pagamento desses trabalhadores está submetido ao orçamento do Estado. Além disso, alegava-se que o regime dos servidores é institucional e não contratual, como ocorre com os trabalhadores do setor privado.

Em muitos países, o princípio que regula as relações de trabalho entre os servidores públicos e o Estado deixa a cargo deste último determinar unilateralmente tanto a remuneração como as demais condições de trabalho neste setor. A base ideológica que sustenta os fundamentos desse princípio é a doutrina da soberania do Estado, segundo a qual, tal ente, "por ser o representante da vontade popular (ou de interesses gerais), tem o direito indiscutível de atuar unilateralmente em tudo o que diz respeito ao poder legislativo, direito que não pode ser impugnado por grupos que representam interesses particulares, como são as organizações dos servidores públicos". ${ }^{281}$

Os ordenamentos jurídicos que são baseados neste princípio têm como característica comum o fato de não fazerem uma dissociação entre a função do Estado enquanto empregador e aquela função que desempenha enquanto poder soberano. ${ }^{282}$

A posição dos Estados era, na maioria das vezes, de resistência em relação à possibilidade de negociação coletiva com os servidores públicos. Mesmo quando elas eram aceitas na prática, o seu reconhecimento oficial demorava a ocorrer. Após a Segunda Guerra Mundial, em muitos países a negociação coletiva passou a ser um instrumento predominante de determinação das condições de trabalho no setor privado, o que resultou na sensível melhora para esses trabalhadores, os quais passaram a ocupar uma posição mais favorável em comparação com aqueles do setor público. Entre outros fatores, esse fato contribuiu para que os servidores públicos tomassem consciência da necessidade de defender os seus interesses tal qual ocorria com os trabalhadores do setor privado, sendo assim, foi impulsionada a organização coletiva sob a forma de sindicatos no setor público. ${ }^{283}$

Alice Monteiro de Barros assevera que "a partir da década de 60, consolida-se a sindicalização no serviço público e começa a expandir-se a negociação coletiva,

\footnotetext{
${ }^{281}$ OZAKI, M. op. cit., p. 314.

${ }^{282}$ Id., loc. cit., p. 314.

${ }^{283}$ Id. Ibid., p. 313.
} 
manifestando-se no cenário internacional por meio das Convenções de n. 87, 98, 151, e 154, todas da OIT." ${ }^{284}$ Isso ocorre, sobretudo, em função do surgimento de movimentos reivindicatórios dos servidores públicos, que passaram a lutar por direitos já consolidados no setor privado, o que provocou o reconhecimento do direito de sindicalização dos servidores públicos civis em ordenamentos jurídicos de muitos países. ${ }^{285}$

A Convenção n. 87 da OIT, ainda não ratificada pelo Brasil, que trata da liberdade sindical e da proteção ao direito de sindicalização, em seu artigo 2 estabelece que:

"Os trabalhadores e as entidades patronais, sem distinção de qualquer espécie, têm o direito, sem autorização prévia, de constituírem organizações da sua escolha, assim como o de se filiarem nessas organizações, com a única condição de se conformarem com os estatutos destas últimas". 286

Deste texto se depreende que este direito está assegurado aos trabalhadores e empregadores sem nenhuma distinção, ou seja, ele excluiu todo o tipo de discriminação, inclusive em relação aos servidores públicos.

A Convenção n. 98 da OIT, ratificada pelo Brasil, que trata do direito de sindicalização e de negociação coletiva, estabelece em seu artigo $5^{\circ}$ que:

"A legislação nacional definirá a medida em que se aplicarão às forças armadas e à polícia as garantias providas nesta Convenção”. ${ }^{287}$

E ainda, esse mesmo instrumento normativo da Organização Internacional do Trabalho, no seu artigo $6^{\circ}$, estabelece:

"Esta Convenção não trata da situação de funcionários públicos a serviço do Estado e nem será de algum modo interpretada em detrimento de seus direitos ou situação." 288

A Convenção n. 151 da OIT, não ratificada pelo Brasil, ${ }^{289}$ trata das relações de trabalho na função pública e preceitua em seu artigo $7^{\circ}$ que:

\footnotetext{
${ }^{284}$ BARROS, Alice Monteiro. Curso de direito do trabalho. 4. ed. São Paulo: LTr, 2008. p. 1245.

${ }^{285}$ SILVA, Walküre Lopes Ribeiro. Liberdade sindical no contexto dos direitos humanos: a experiência da OIT, cit., p. 215.

${ }^{286}$ ORGANIZAÇÃO INTERNACIONAL DO TRABALHO. Convenção n. 87, OIT. Disponível em: $<$ http://www.ilo.org/ilolex/portug/docs/convdisp1.htm>. Acesso em: 15 jan. 2009.

${ }^{287}$ Id. Convenção n. 98, OIT, cit.

${ }^{288}$ Id. Ibid.

${ }^{289}$ O Poder Executivo apresentou em 20/02/08 a MSC-58/2008, para tramitação em regime de prioridade, a qual submete à apreciação do Congresso Nacional os textos da Convenção n. 151 e da Recomendação $n$. 159, da Organização Internacional do Trabalho, ambas de 1978, sobre as Relações de Trabalho na Administração Pública.
} 
"Quando necessário, devem ser tomadas medidas adequadas às condições nacionais para encorajar e promover o desenvolvimento $e$ utilização dos mais amplos processos que permitam a negociação das condições de trabalho entre as autoridades públicas interessadas e as organizações de trabalhadores da função pública ou de qualquer outro processo que permita aos representantes dos trabalhadores da função pública participarem na fixação das referidas condições. "290

É importante observar que esta Convenção se aplica a todas as pessoas empregadas na administração pública, no entanto, permite exceções: os agentes de nível elevado, que, geralmente, ocupam funções de direção; os agentes que tem responsabilidades de caráter confidencial, a exemplo das forças armadas e da polícia.

A Convenção n. 154 da OIT, ratificada pelo Brasil, que trata especificamente da negociação coletiva, prevê em seu artigo 1, item 3 que:

"No que se refere à administração pública, a legislação ou a prática nacionais poderão fixar modalidades particulares de aplicação a esta Convenção". ${ }^{291}$

E, ainda, no item 2 deste mesmo artigo:

"A legislação ou a prática nacionais poderão determinar até que ponto as garantias previstas na presente Convenção são aplicáveis às forças armadas e à polícia”. ${ }^{292}$

Há uma tendência nos países estrangeiros em possibilitar ao servidor público o direito de negociação coletiva como ocorre no setor privado. Alice Monteiro de Barros nos faz lembrar que "o direito comparado revela um número razoável de países onde a negociação coletiva no setor público está assegurada ou na lei ou no costume". ${ }^{293}$ Não se discute que o ordenamento desses países também está sob os princípios da previsão orçamentária e da legalidade, sem que isso seja uma impossibilidade para a negociação coletiva de trabalho no serviço público.

O Estado, de forma geral, tornou-se o maior empregador em todo o mundo, de forma que, parte significativa do seu orçamento ficou comprometida com as despesas com

\footnotetext{
${ }^{290}$ ORGANIZAÇÃO INTERNACIONAL DO TRABALHO. Convenção n. 151, OIT. Disponível em: <http://www.ilo.org/ilolex/portug/docs/convdisp1.htm>. Acesso em: 15 jan. 2009.

${ }^{291}$ Id. Convenção n. 154, OIT. Disponível em: <http://www.ilo.org/ilolex/spanish/convdisp1.htm>. Acesso em: 15 jan. 2009.

${ }^{292}$ Id. Ibid.

${ }^{293}$ BARROS, Alice Monteiro. op. cit., 4. ed., p. 1246.
} 
pessoal. ${ }^{294}$ A partir do declínio do Estado de bem-estar social, acirraram-se os conflitos entre os servidores públicos e o Estado. Ocorreu um movimento de equivalência das condições de trabalho e, por isso, surgiu a necessidade da negociação coletiva de trabalho também neste setor.

Arion Sayão Romita afirma que "a necessidade de reduzir custos para compatibilizá-los com os escassos recursos orçamentários corroeu a imagem do Estado (...) ampliou-se a área de conflitos entre o Estado e os seus servidores. Começaram a ser adotados métodos de colaboração, os quais variam de país para país, combinando a informação, a consulta, a negociação e a participação, propiciando uma crescente influência dos servidores na determinação de suas condições de trabalho". ${ }^{295}$

Na Itália, por exemplo, há negociação coletiva no serviço público. A questão da previsão orçamentária é resolvida com a antecedência da negociação coletiva para que sejam permitidas adaptações à lei orçamentária. Quanto ao princípio da legalidade, se resolve o problema da seguinte forma: se faz uma "hipótese de acordo" que é transformada em lei, sem qualquer alteração em seu conteúdo. Aquele fenece, para logo depois renascer em forma de lei, tal qual a fênix que morre e renasce das cinzas. ${ }^{296}$

No Brasil, logo após a promulgação da Constituição de 1988, a doutrina se dividiu entre os que sustentavam a possibilidade de negociação coletiva e, portanto, de convenção e acordo coletivo no serviço público e aqueles que consideravam isso impossível. ${ }^{297}$

O primeiro grupo sustentava que, muito embora a Constituição de 1988 não tivesse estendido aos servidores públicos o inciso XXVI do artigo $7^{\circ}$, que dispõe de forma expressa sobre a convenção e acordo coletivo, acabou por admiti-los uma vez que considerou aplicável aos servidores públicos o inciso VI, que faz referência à possibilidade de redução salarial por meio deles.

Arion Sayão Romita argumenta que, embora o tema da remuneração escape do âmbito da negociação coletiva pela reserva legal conferida pelo artigo $61, \S 1^{\circ}$, II, $a$, o texto da "Constituição não proíbe o sindicato de servidores públicos de celebrar convenções e acordos coletivos. Quando quer proibir o exercício de algum direito, a

\footnotetext{
${ }^{294}$ ROMITA, Arion Sayão. Servidor público: sindicalização, negociação coletiva, conflitos coletivos, direito de greve. LTr: revista legislação do trabalho, v. 56, n. 7, p. 790, jul 1992.

${ }^{295}$ Id., loc. cit.

${ }^{296}$ GHEZZI, Giorgio; ROMAGNOLI, Umberto. Il diritto sindacale. 3.ed. Bologna: Zanichelli, 1992. p. 183184.

${ }^{297}$ BARROS, Alice Monteiro. op. cit., 4. ed., p. 1246.
} 
Constituição dispõe expressamente sobre a vedação, como ocorreu com a sindicalização e a greve dos militares (art. 42, $\S 5^{\circ}$ ). Ao incluir o direito de sindicalização dos servidores entre os preceitos que regem a administração pública direta indireta e fundacional (art. 37, VI), a Constituição estava automaticamente dispensada de proclamar o reconhecimento das convenções e acordos coletivos em favor dos servidores públicos: incorreria em evidente bis in idem, realmente inadmissível no texto da Lei Maior". ${ }^{298}$

Enoque Ribeiro dos Santos e Juliana Araújo Lemos da Silva partilham “do entendimento de que mesmo no âmbito da Administração Pública é possível a negociação coletiva de trabalho, pois é justamente dela que defluem os demais institutos (acordo, convenção coletiva, arbitragem, dissídio coletivo e greve). A negociação coletiva de trabalho em si não se confunde com os instrumentos jurídicos que dela defluem. Constitui apenas o melhor meio para se alcançar a solução do conflito coletivo". Eles acreditam "não existir qualquer óbice à negociação de trabalho no setor público, desde que se tenha por fim não a celebração formal de um acordo coletivo, mas sim, a assunção de um compromisso político e moral por parte da autoridade pública competente no sentido de propor projeto de lei - ou solicitar sua propositura, quando não tiver tal competência - que contemple a solução emanada das discussões e do consenso verificado na negociação coletiva",299

O outro grupo não admitiu a negociação coletiva, nem tampouco as convenções e acordos coletivos aos servidores. Sustentavam a sua posição no fato do regime dos servidores públicos terem natureza institucional e não contratual. Deste modo, a relação jurídica deveria ser fixada unilateralmente por meio de leis, decretos e regimentos. Essa corrente admitia que, a possibilidade dos servidores organizarem sindicatos, não lhes garantia a possibilidade de negociar, celebrar convenções coletivas ou suscitar dissídio coletivo de natureza econômica, de forma que, o sindicato dos servidores apenas podia ajuizar dissídio coletivo de natureza jurídica. ${ }^{300}$

O STF não reconhece ao servidor público o direito de negociação coletiva de trabalho. Isso com fundamento na argumentação de que, conferir tal direito afronta dois princípios constitucionais, o da previsão orçamentária e o do princípio da legalidade.

\footnotetext{
${ }^{298}$ ROMITA, Arion Sayão. op. cit., p. 798-799.

${ }^{299}$ SANTOS, Enoque Ribeiro dos; SILVA, Juliana Araújo Lemos da. Direito de greve do servidor público como norma de eficácia contida. Revista de Direito do Trabalho, São Paulo, v. 30, n. 116, p. 230, out./dez. 2004.

${ }^{300}$ BARROS, Alice Monteiro. op. cit., 4. ed., p. 1247.
} 
A Lei n. 8.112, de 11 de dezembro de 1990, que instituiu o regime jurídico único para os servidores públicos civis da União, das autarquias e fundações públicas federais estabelece:

"Art. 240. Ao servidor público civil é assegurado, nos termos da Constituição Federal, o direito à livre associação sindical e os seguintes direitos, entre outros, dela decorrentes:

a) de ser representado pelo sindicato, inclusive como substituto processual;

b) de inamovibilidade do dirigente sindical, até um ano após o final do mandato, exceto se a pedido;

c) de descontar em folha, sem ônus para a entidade sindical a que for filiado, o valor das mensalidades e contribuições definidas em assembléia geral da categoria.

d) de negociação coletiva; (Mantido pelo Congresso Nacional) (Revogado pela Lei $n^{\circ}$ 9.527, de 10.12.97)

e) de ajuizamento, individual e coletivamente, frente à Justiça do Trabalho, nos termos da Constituição Federal. (Mantido pelo Congresso Nacional) (Revogado pela Lei $n^{\circ} 9.527$, de 10.12.97)" ${ }^{301}$

As alíneas " $d$ " e " $e$ " do artigo 240 da Lei n. 8.112/1990, publicada em 19/04/1991, foram objeto de Ação Direta de Inconstitucionalidade de $n^{\circ}$ 492-1 DF, proposta pelo Procurador-geral da República, sob a alegação de que os referidos dispositivos contrariam os artigos 37, 41, e 114 da Carta Magna.

O STF julgou procedente o pedido ao declarar a inconstitucionalidade das alíneas com base na natureza estatutária da relação jurídica dos servidores públicos, fato que, segundo a decisão do tribunal, torna inconciliável o regime dos servidores públicos com a negociação coletiva e com o direito de ação coletiva neste setor. Nesta concepção, o regime dos servidores implica que seus direitos, deveres, garantias e vantagens são definidos unilateralmente pelo Estado-legislador, podendo, inclusive alterá-lo unilateralmente a qualquer momento, sem que o servidor possa cogitar na manutenção do regime anterior.

Além disso, fundamenta o STF a sua decisão no princípio da legalidade ao declarar que toda a sistemática de vencimentos e vantagens dos servidores públicos assenta-se na lei. E complementa afirmando que a Constituição determina que a lei que dispõe sobre a criação de cargos, funções ou empregos públicos na administração direta e

\footnotetext{
${ }^{301}$ PRESIDÊNCIA DA REPÚBLICA. Lei n. 8.112, de 11 de dezembro de 1990. Disponível em: <http://www.planalto.gov.br/ccivil_03/LEIS/L8112cons.htm>. Acesso em: 15 jan. 2009.
} 
autárquica ou aumento de remuneração é de iniciativa privativa do Presidente da República, conforme o artigo 61, $\S 1^{\circ}$, II, " $a$ " da Constituição. Também a decisão do STF baseou-se no argumento de que a Constituição Federal, no $\S 3^{\circ}$ do artigo 39, não garantiu aos servidores públicos o artigo $7^{\circ}$, inciso XXVI, que garante o reconhecimento das convenções e acordos coletivos de trabalho.

No entanto, a competência privativa do Presidente da República prevista no artigo 61 da Constituição Federal quanto à criação de cargos, empregos e funções públicas e à remuneração dos servidores públicos não é abalada ou reduzida pela negociação coletiva. $\mathrm{Na}$ verdade, a competência presidencial será valorizada por ela, ${ }^{302}$ na medida em que, por meio do diálogo com os interessados, o presidente terá elementos seguros para decidir.

A participação dos servidores públicos, por meio dos seus sindicatos representativos, regulada por lei junto ao governo servirá como forma de composição de interesses divergentes com "chances de maior eficácia e duração no tempo, além de enriquecer com sugestões, estudos e propostas do próprio servidor, em razão da experiência provinda do exercício dos cargos públicos". 303

Os temas levados à mesa de negociação nem sempre dizem respeito apenas à remuneração. Como observa Robertônio Santos Pessoa, "boa parte das greves deflagradas nos últimos anos na administração pública decorreu da negação das autoridades competentes em negociarem diretamente com os servidores problemas relativos às condições de trabalho no setor público. Sendo assim, a greve tem sido a única forma encontrada pelos sindicatos para levarem as administrações públicas à mesa de negociação". 304

Muitas greves reivindicam outras questões relativas às condições de trabalho dos servidores públicos, além da remuneração. Esses temas envolvem, portanto, interesses também da sociedade como um todo e, principalmente, daqueles que usam os serviços prestados, porque interferem direta ou indiretamente na qualidade deles. Exemplos dessas reivindicações dizem respeito à jornada de trabalho; à necessidade de novas contratações para aliviar a carga excessiva de trabalho e, consequientemente, prestar um melhor atendimento aos usuários dos serviços; a equipamentos obsoletos ou à falta de material necessário para a perfeita prestação dos serviços etc.

\footnotetext{
${ }^{302}$ SILVA, Antônio Álvares da. Os servidores públicos e o direito do trabalho. São Paulo: LTr, 1993. p. 147. ${ }^{303}$ Id., loc. cit.

${ }^{304}$ PESSOA, Robertônio Santos. op. cit., p. 76.
} 
É indiscutível o fato de que a remuneração dos servidores públicos está sujeita a limitações orçamentárias, mas isso não inviabiliza a negociação coletiva. Essa limitação de ordem pública, assim como a iniciativa de leis pelo Presidente da República não são empecilhos. A "lei pactuada" ou aquela que teve o seu conteúdo previamente discutido ${ }^{305}$, sendo, portanto, fruto da composição de interesses conflitantes, corresponde a um avanço das democracias modernas.

Mesmo mantendo-se um sistema baseado na determinação unilateral das condições de trabalho, alguns países estabelecem dispositivos oficiais de consulta paritária, entre a administração pública e as organizações de servidores públicos, a respeito das condições de trabalho e da remuneração. Na prática, podem ocorrer negociações de fato, apesar de ser difícil a delimitação entre as duas figuras (consulta paritária e negociação coletiva), principalmente no setor público, o qual, na maioria das vezes, a negociação coletiva depende de aprovação do legislativo. ${ }^{306}$

Alice Monteiro de Barros observa que "esses fatos dificultam a possibilidade de existirem convenções coletivas de trabalho na Administração Pública direta no Brasil, já que seu pressuposto é a negociação coletiva. Aliás, mesmo que a negociação coletiva se viabilize, o entendimento só poderia ser formalizado via heterônoma (por meio do Poder Legislativo ou Executivo - art. 61, §1º, II, “a”, da Constituição da República de 1988), em face dos limites impostos ao exercício do poder de transigir, evitando-se o comprometimento do erário."

E a autora ainda adverte: "Note-se, entretanto, que a decisão do STF e a Lei n. 9.527, de 1997, não encerram a discussão em torno da negociação coletiva no serviço público, mesmo porque o direito de sindicalização dos servidores continua, e esses sindicatos podem firmar acordos destituídos de valor jurídico, mas com valor político, atuando como grupos de pressão, visando a influenciar a atividade de produção normativa, que era privilégio da administração, à semelhança do que ocorreu na Itália anteriormente à Lei n. 93, de 1983." 307

A fórmula proposta pela Convenção 151 da OIT, sobre a proteção de direito de sindicalização e os procedimentos para determinar as condições de emprego na administração, é no sentido das disposições legislativas e regulamentares poderem ser

\footnotetext{
${ }^{305}$ SILVA, Antônio Álvares da. op. cit., p. 147.

${ }^{306}$ OZAKI, M. op. cit., p. 316.

${ }^{307}$ BARROS, Alice Monteiro. op. cit., 4. ed., p. 1247.
} 
negociadas com os sindicatos. Estas negociações no serviço público, "se bem que se dêem somente a título consultivo ou de proposta e acabem numa disposição autônoma do Estado (lei ou regulamento), possuem de fato uma grande força, precisamente por causa da ameaça da greve. Desenvolve-se, portanto, uma negociação informal por meio da ameaça da paralisação coletiva, ainda que possa ser ilegal". ${ }^{308}$

Mesmo antes da Constituição de 1988 os governantes, reiteradamente, vêm reconhecendo a legitimidade dos conflitos coletivos entre a administração e os servidores públicos e sentando à mesa de negociações. No entanto, essa atitude é tomada em caráter informal, "sem renunciar em definitivo à faculdade de acionar o direito autoritário professado pelos juristas tradicionais e aplicado pelos tribunais conservadores, direito que preservam como reserva técnica para o exercício da repressão quando o confronto se agudiza ou se prolonga". 309

\subsubsection{Histórico}

O Estado brasileiro, assim como outros, teve um desenvolvimento urbanoindustrial tardio. Tal fato trouxe como consequiência a necessidade da presença estatal nos setores produtivos ligados à infra-estrutura básica. Coube ao Estado, à época, superar as dificuldades tecnológicas e econômico-financeiras impostas pela realidade complexa das economias dos países capitalistas hegemônicos. ${ }^{310}$

Em função desta realidade, o Estado arregimentou não só recursos financeiros, como também, um contingente de trabalhadores ocupados no setor público, que incluem aqueles localizados no serviço público federal, bem como, aqueles no setor produtivo estatal.

Esse contingente de trabalhadores cujo empregador é o Estado garantiu um espaço de atuação coletiva. Antes mesmo da Constituição de 1988, já era possível observar uma vitalidade dos sindicatos que têm por base as empresas estatais e, também, a presença de associações de trabalhadores do serviço público direto.

\footnotetext{
${ }^{308}$ LÓPEZ-MONÍS DE CAVO, Carlos. op. cit., p. 24.

${ }^{309}$ COELHO, Rogério Viola. A relação de trabalho com o Estado: uma abordagem crítica da doutrina administrativa da relação de função pública. São Paulo: LTr, 1994. p. 74.

${ }^{310}$ GUEDES, Cezar. Os trabalhdores no setor público brasileiro: prática sindical, conquistas e armadilhas. Análise do período pós-1978. In: OLIVEIRA, C. A. B. et al. O mundo do trabalho: crise e mudança no final do século. Campinas: Ed. Página Aberta, 1994. p. 403-404.
} 
Como assevera Cezar Guedes, "no caso do serviço público direto, a formação de associações de funcionários ocupou o vazio de representação herdada da legislação, que negava este direito. Este é o caso de médicos e professores, que foram as categorias de ponta no processo organizativo e que 'puxaram' as greves do funcionalismo público a partir de 1979". 311

No entanto, é importante lembrar que até o final da Segunda Guerra Mundial tanto a sindicalização como a negociação coletiva eram negadas aos servidores públicos. Estes últimos eram regidos exclusivamente pelas regras do direito administrativo. Essa proibição baseava-se no argumento de que a organização administrativa fundava-se na ordem hierárquica. Desta forma, as intervenções de forças sociais e econômicas eram consideradas incompatíveis com a autoridade do Estado. ${ }^{312}$

A investigação quanto à posição da função pública na sistemática do direito resultou na idéia, propugnada por teóricos alemães dos séculos XVII e XVIII em suas obras, de que na sua essência ela trazia consigo um comportamento de sujeição absoluta por parte daquele que desempenhava a função pública em relação ao Estado. José Cretella Júnior descreve: "Nas obras dos teóricos alemães dos séculos XVII e XVIII, encontramos repetidas e curiosas investigações sobre a essência da função pública, julgando alguns haver por parte de quem a desempenha sujeição absoluta ao órgão estatal, verdadeira situação de escravo perante o senhor, imaginando outros tratar-se de relação conhecida e legal, amparada por disposições tradicionais do Direito Romano e que precisavam apenas ser aplicadas ao caso em espécie." 313

Os teóricos do direito administrativo ao determinar a natureza jurídica do vínculo existente entre aqueles que desempenham uma função pública e o Estado adotam posições nitidamente opostas: a unilateral e a contratual. ${ }^{314}$

A teoria unilateral pode ser dividida em dois grupos doutinários. O primeiro deles, o da coação legal, surgiu na Alemanha e tem hoje apenas um valor histórico. De acordo com ele, a investidura da função pública seguiria apenas a vontade unilateral do Estado imposta de forma coativa aos seus súditos. Isso porque o Estado não poderia ficar na dependência da vontade dos indivíduos e, muito menos, se sujeitaria a contratar com

\footnotetext{
${ }^{311}$ GUEDES, Cezar. op. cit., p. 409.

${ }^{312}$ BARROS, Alice Monteiro. op. cit., 2. ed., p. 1206.

${ }^{313}$ CRETELLA JUNIOR, José. op. cit., p. 22.

${ }^{314}$ Id. Ibid., p. 27.
} 
aqueles que exercem uma função pública e, assim, faria uso do jus imperii em relação à obrigatoriedade da função pública. ${ }^{315}$

A segunda doutrina pertencente à teoria unilateral é a chamada situação legal ou regulamentar. Essa teoria não pregava a coação dos indivíduos que exercem função pública, mas procurava estabelecer as condições, por meio de leis e regulamentos, indispensáveis ao seu exercício. ${ }^{316}$ Aquele que se propõe a exercer a função pública aceita livremente a situação apresentada pelo Estado. De acordo com essa teoria não há contrato, uma vez que esse instrumento supõe a livre discussão das cláusulas pelos contratantes. Além disso, mesmo depois de firmada a relação jurídica entre aquele que exerce a função pública e o Estado, este último pode modificar unilateralmente as condições de trabalho com vistas à defesa do interesse público.

A teoria contratual, por sua vez, conta com três modelos distintos: o contrato de direito privado, o contrato de direito misto e o contrato de direito público. A idéia de que o contrato é figura peculiar do direito privado levou os teóricos filiados à teoria contratualista a justificar a natureza jurídica da função pública entre as figuras contratuais conhecidas, tais como: contrato de precário, contrato de doação, contrato de locação de serviços, contrato de mandato do direito civil, gestão de negócios, contrato inominado etc. Certos da natureza contratual da função pública e das peculiaridades dessa relação jurídica, reconhecidamente de direito público, e, ainda, diante da dificuldade de se encontrar no direito privado uma figura que explicasse satisfatoriamente a sua essência, parte da doutrina recorreu a um artifício engenhoso, porém carente de fundamento jurídico. Passaram a enquadrar a função pública, em razão do seu hibridismo, em uma categoria chamada contrato de direito misto. ${ }^{317}$

Uma outra concepção doutrinária defendia a tese do contrato de direito público em face da não aplicação das normas de direito privado à função pública. ${ }^{318}$

Os servidores públicos surgiram como um gênero especial de pessoas ligadas à nobreza feudal e progressivamente foram crescendo em número e em atribuições. No século XIX, em contrapartida à fidelidade que dispensavam aos monarcas, recebiam salário regular e gozavam de direitos como segurança no emprego e aposentadoria. ${ }^{319}$

\footnotetext{
${ }^{315}$ CRETELLA JUNIOR, José. op. cit., p. 28-29.

${ }^{316}$ Id. Ibid., p. 30-31.

${ }^{317}$ Id. Ibid., p. 34.

${ }^{318}$ Id. Ibid., p. 36.

${ }^{319}$ SILVA, Antônio Álvares da. op. cit., p. 19.
} 
Esses direitos, quando comparados à situação dos demais trabalhadores, principalmente após a Revolução Industrial, ganharam ares de privilégios. Essa situação comparativamente vantajosa dos servidores públicos provavelmente tenha inibido qualquer movimento reivindicatório deles, "além de não precisarem da militância sindical, o ingresso em associações lhes era expressamente vetado". 320

Alegava-se que os servidores públicos ocupavam uma situação privilegiada em relação aos trabalhadores do setor privado $^{321}$, fato que desestimulava a organização coletiva. E, ainda, como ao servidor público não era permitida a greve, um dos principais instrumentos dos sindicatos, também a sindicalização não era autorizada.

Brioschi e Setti já advertiam que "não pode ser esquecido que o funcionário goza de toda uma série de garantias, de uma notável estabilidade, de uma situação jurídica, em suma, que o põe em condições de privilégio diante de outros trabalhadores, torna-se muito pouco justificável a greve e quase inútil a organização sindical”. ${ }^{322}$

Ozaki também observa que "muito tempo depois que os 'servidores do monarca' se converteram nos 'servidores do público', persistiu na opinião pública e na mentalidade dos próprios interessados a antiga idéia de que os funcionários públicos representam o poder soberano e pertencem a uma categoria privilegiada de pessoas. Esta concepção freou no passado a participação ativa dos funcionários públicos nas atividades sindicais". 323

O autor ainda adverte que "depois da Segunda Guerra Mundial, e sobretudo a partir da década de 1960, começaram a se produzir mudanças fundamentais na atitude dos funcionários públicos a propósito das suas relações de trabalho. Em conseqüência da rápida expansão das atividades do setor público, cresceu consideravelmente o número dos funcionários públicos, sobretudo nos serviços de educação, saúde e proteção social, distantes da concepção tradicional da administração do Estado como exercício de um poder soberano. O aumento do número de funcionários produziu também certa erosão de seus privilégios". 324

$\mathrm{Na}$ atualidade, como assevera Carlos López-Monís de Cavo, “a situação trabalhista na qual se encontra hoje o funcionário público não é substancialmente melhor que a do trabalhador no setor privado. Se indagarmos alguns aspectos históricos, sobre as

\footnotetext{
${ }^{320}$ SILVA, Antônio Álvares da. op. cit., p. 19.

${ }^{321}$ LÓPEZ-MONÍS DE CAVO, Carlos. op. cit., p. 25.

${ }^{322}$ BRIOSCHI, Gian Antonio; SETTI, Federico. op. cit., p. 83.

${ }^{323}$ OZAKI, M. op. cit., p. 313.

${ }^{324}$ Id., loc. cit.
} 
disciplinas que regulamentam estas duas relações, resultarão dois processos históricos diversos, já que, no século passado, enquanto as condições de emprego do pessoal público chegaram a uma regulamentação de certa forma aceitável, no setor privado, ao contrário, havia tão-somente alguns escassos artigos referentes aos contratos civis que regulamentam tais relações (...) quando o direito do trabalho nasce e se desenvolve sob o impulso da pressão trabalhadora organizada, o equilíbrio muda de ponto, ficando então o setor de emprego público em situação comparativamente inferior, porque está sob a influência do princípio da autoridade da administração pública". ${ }^{325}$

Na Itália, o código penal Zanardelli punia os funcionários públicos que em número de três ou mais abandonassem o trabalho. Também a Lei n. 693 de 1908, chamada "legge capestro", previa punição de dispensa do serviço para o abandono voluntário que provocasse a interrupção ou a perturbação na continuidade ou regularidade da prestação do serviço, sem prejuízo da sanção penal. Durante o período fascista havia uma proibição geral da greve na qual também se inclui o servidor público, o qual podia ser punido com sanção penal. Era considerado, na legislação italiana que regulava a relação jurídica dos servidores civis da administração do Estado, demissionário o servidor grevista. Naturalmente, essas punições não foram acolhidas pela Constituição Italiana de 1948 que reconheceu o direito de greve de forma geral. ${ }^{326}$

Hodiernamente, o direito de greve dos servidores públicos é reconhecido na maioria dos ordenamentos. ${ }^{327}$ No Brasil, ele está garantido na Constituição, no entanto, o seu exercício enfrenta dificuldades, principalmente no setor público, apesar disso, a realidade nos apresenta um grande contingente de greves neste setor. A seguir, iremos investigar o processo de evolução pelo qual passou o ordenamento brasileiro em relação esse direito.

\subsubsection{Evolução legislativa brasileira}

No Brasil, a evolução histórica da greve de certa forma reproduziu o esquema observado na Europa passando pelas fases de tolerância, proibição e reconhecimento como

\footnotetext{
${ }^{325}$ LÓPEZ-MONÍS DE CAVO, Carlos. op. cit., p. 25.

${ }^{326}$ BRIOSCHI, Gian Antonio; SETTI, Federico. op. cit., p. 84.

${ }^{327}$ MEDAUAR, Odete. op. cit., p. 279.
} 
delito e como direito. ${ }^{328}$ No entanto, ao contrário do que ocorreu em outros países, nos quais os conceitos de greve delito, greve liberdade e greve direito obedeceram uma sucessão cronológica, no Brasil, primeiro deu-se a concepção da greve liberdade e, posterior e sucessivamente, a de greve delito e greve direito. ${ }^{329}$

A greve, antes de 1930 e a partir do início do século XX, era praticada livremente. ${ }^{330}$ Esse fato pode ser explicado mais pela realidade social e econômica brasileira que pela mentalidade da época a respeito do tema. A escravidão fora abolida havia pouco, de forma que a sociedade brasileira ainda vivia os reflexos da economia escravista. $\mathrm{O}$ trabalho verdadeiramente urbano era praticamente inexpressivo e disperso, já que a nossa economia era baseada no trabalho escravo e agrícola e a indústria ainda dava os seus primeiros passos, fato que dificultava qualquer mobilização dos trabalhadores no sentido de luta pelos interesses comuns. ${ }^{331}$ Durante o Império, em razão da prevalência do trabalho escravo, a greve não era cogitada. ${ }^{332}$ Em 1890, um ano após a Proclamação da República, o Código Penal passou a conter proibição à greve, no entanto, a primeira Constituição republicana brasileira, de 1891, foi omissa em relação à greve. Os dispositivos da lei penal tiveram uma curta permanência no ordenamento pátrio, pois o Decreto $\mathrm{n}^{\mathrm{o}} 1.162$ de 12 de dezembro do mesmo ano foi modificado no sentido de considerar a greve lícita. ${ }^{333}$

Após 1930 o país abandona os padrões do liberalismo vigentes até então e abre espaço para as experiências corporativistas já em curso na Europa, alterando o posicionamento perante a greve como pode ser observado no Decreto n. 21.396, de 12 de maio de 1932 e na Lei n. 38, de 04 de abril de 1935 . $^{334}$ Este primeiro diploma legal institui comissões mistas de conciliação e arbitragem, para dirimir dissídios entre empregados e empregadores, e estabelece a possibilidade destes serem suspensos ou dispensados na hipótese de abandono de trabalho, sem prévio entendimento com aqueles. O segundo, conhecido como Lei da Segurança Nacional, assume claramente a concepção da greve como delito.

\footnotetext{
${ }^{328}$ GOMES, Orlando; GOTTSCHALK, Elson. op. cit., p. 621.

${ }^{329}$ MAGANO, Octavio Bueno. Direito coletivo do trabalho, cit., p. 187.

${ }^{330}$ GOMES, Orlando; GOTTSCHALK, Elson. op. cit., p. 621-622.

${ }^{331}$ MORAES FILHO, Evaristo. op. cit., p. 182.

${ }^{332}$ MAGANO, Octavio Bueno. Direito coletivo do trabalho, cit., p. 187.

${ }^{333}$ MORAES, Evaristo. Apontamentos de direito operário. 3. ed. São Paulo: LTr, 1986. p. 58-59.

${ }^{334}$ MAGANO, Octavio Bueno. Direito coletivo do trabalho, cit., p. 187.
} 
A Constituição de 1934 foi omissa quanto ao direito de greve, porém assegurou no artigo 120, parágrafo único, a liberdade sindical, ao prever que "a lei assegurará a pluralidade sindical e a completa autonomia dos sindicatos”. Porém, a liberdade sindical não era observada, pois era cerceada no plano infraconstitucional com decretos que restringiam a liberdade de organização e de atuação sindical. ${ }^{335}$

A Constituição de 1937, na parte final do artigo139, declarava a greve, assim como o lock-out, "recursos anti-sociais nocivos ao trabalho e ao capital e incompatíveis com os superiores interesses da produção nacional". ${ }^{336}$ A proibição da greve nesta Constituição era reflexo do modelo corporativista adotado pelo Estado Novo, que pregava a harmonia das classes sociais e a supremacia dos interesses do Estado. ${ }^{337}$

O Decreto-Lei n. 431, de 18 de maio de 1938, relativo à segurança nacional, previa três modalidades de crimes resultantes de greve: (i) incitamento de funcionários públicos ou servidores do Estado à cessação coletiva, total ou parcial, dos serviços a seu cargo; (ii) induzimento de empregados à cessação ou suspensão do trabalho; (iii) cessação coletiva do trabalho por parte de funcionários públicos, contra a lei ou o regulamento. ${ }^{338}$

O Decreto-Lei n. 1.237, de 02 de maio de 1939, que instituiu a Justiça do Trabalho, também declarou que a greve seria passível de sanções, que iam de penas de suspensão e dispensa até a prisão. O Código Penal de 1940 previa como crime a greve e o lock-out, no Título IV, entre os crimes contra a organização do trabalho. Neste caso, a paralisação de trabalho era considerada crime quando praticada seguida da perturbação da ordem ou quando contrariava interesse coletivo. ${ }^{339}$

A Constituição de 18 de setembro de 1946, em seu artigo 158, consagra, pela primeira vez, a greve como direito, ao estabelecer que "é reconhecido o direito de greve, cujo exercício a lei regulará". ${ }^{340}$ No entanto, ao remeter o exercício de greve à lei ordinária, passou-se a aplicar o Decreto-lei n. 9.070 de 15 de março de1946, que proibia a greve nas

\footnotetext{
${ }^{335}$ SILVA, Walküre Lopes Ribeiro da. A disciplina jurídica da greve e as constituições republicanas no Brasil, cit., p. 147.

${ }^{336}$ CONSTITUIÇÃO DOS ESTADOS UNIDOS DO BRASIL (de 10 de novembro de 1937). Disponível em: $<$ http://www.planalto.gov.br/CCIVIL/Constituicao/Constitui\%C3\%A7ao37.htm>. Acesso em: 14 jan. 2009.

${ }^{337}$ SILVA, Walküre Lopes Ribeiro da. A disciplina jurídica da greve e as constituições republicanas no Brasil, cit., p. 147.

${ }^{338}$ MAGANO, Octavio Bueno. Direito coletivo do trabalho, cit., p. 187-188.

${ }^{339}$ Id. Ibid., p. 188.

${ }^{340}$ CONSTITUIÇÃO DOS ESTADOS UNIDOS DO BRASIL (de 18 de setembro de 1946). Disponível em: <http://www.planalto.gov.br/ccivil_03/constituicao/Constitui\%C3\%A7ao46.htm>. Acesso em: 14 jan. 2009.
} 
atividades tidas como fundamentais e a autorizava nas atividades acessórias, porém sob certas condições. Este precedia o texto constitucional, no entanto, sob a alegação da ausência de regulamentação, passou a ser aplicado o que gerou uma grande controvérsia doutrinária, pois alguns juristas apontavam a incompatibilidade do decreto-lei com a nova Constituição. Ela consagrava amplo direito de greve, enquanto ele proibia a greve em atividades fundamentais. ${ }^{341}$

A referida controvérsia também atingiu o direito de greve dos servidores públicos, "havendo prevalecido o entendimento de que os funcionários públicos e os servidores do Estado não tem o direito de fazer greves. Fundamentava-se tal opinião no caráter estatutário da relação entre estes e o Estado, em oposição à relação contratual que se estabelece entre trabalhadores e empregadores". 342

A Lei n. 4.330, de 01 de junho de 1964, permitia a greve nas atividades acessórias e, também, nas atividades fundamentais, no entanto, previa um procedimento legal tão minucioso para deflagração do movimento que era bastante difícil de ser cumprido, o que gerava a ilicitude formal da greve. ${ }^{343}$

A Constituição de 1967, outorgada pelos militares, restringiu o direito de greve, pois em seu artigo 157 , parágrafo $7^{\circ}$, estabeleceu que "não será permitida greve nos serviços públicos e atividades essenciais definidas em lei”. Essa proibição expressa não havia na Constituição anterior. O direito de greve é reconhecido no artigo 158, inciso XXI, salvo nos serviços públicos e atividades essenciais. ${ }^{344}$ A Emenda Constitucional de 1969 manteve os termos da Constituição de 1967 nos artigos 162 e 165, inciso XXI. ${ }^{345}$

Durante o regime militar, diversos diplomas legais que regulamentavam o exercício do direito de greve serviram na verdade para restringir esse direito. Entre eles: (i) o Decreto-lei n. 1.632, de1978, sobre a proibição de greve nos serviços públicos e atividades essenciais de interesse da segurança nacional; (ii) a Lei n. 6.620 de 1978, sobre segurança nacional; (iii) a Lei n. 6.158, de 1974, sobre a proibição de greve de empregados de

\footnotetext{
${ }^{341}$ SILVA, Walküre Lopes Ribeiro da. A disciplina jurídica da greve e as constituições republicanas no Brasil, cit., p. 148-149.

${ }^{342}$ Id. Ibid., p. 149.

${ }^{343}$ Id. Ibid., p. $149-150$.

${ }^{344}$ CONSTITUIÇÃO DA REPÚBLICA FEDERATIVA DO BRASIL DE 1967. Disponível em: <http://www.planalto.gov.br/ccivil_03/constituicao/Constitui\%C3\%A7ao67.htm>. Acesso em 15 jan. 2009.

${ }^{345}$ EMENDA Constitucional n. 1, de 17 de outubro de 1969. Disponível em: <http://www.planalto.gov.br/CCIVIL/constituicao/Emendas/Emc_anterior1988/emc01-69.htm>. Acesso em 15 jan. 2009.
} 
sociedade de economia mista; (iv) a Lei n. 6.185, de 1978, sobre a proibição de greve de empregados de autarquias e órgãos de administração direta. ${ }^{346}$

A despeito de toda a legislação proibitiva e das penalidades previstas, as greves eclodiram a partir de 1978 desencadeadas pelo movimento sindical observado no ABC Paulista, que promoveram greves entre 1978 e 1980. Essas greves metalúrgicas encontraram como motivo central de eclosão a necessidade de se contrapor ao arrocho salarial, além dessa pauta reivindicatória, predominantemente econômica, "as greves assumiram, desde seu desencadear, nítida dimensão política, expressa no confronto que efetivaram contra a base material e a superestrutura jurídico-política da autocracia burguesa". 347

A Constituição de 1988 consagrou o direito de greve no artigo $9^{\circ}$ ao dispor que "é assegurado o direito de greve, competindo aos trabalhadores decidir sobre a oportunidade de exercê-lo e sobre os interesses que devam por meio dele defender". ${ }^{348}$ Como é possível observar, o direito de greve passou e ser expresso de forma clara e precisa, como forma de impossibilitar limitações por meio da legislação infraconstitucional. ${ }^{349}$

Em relação aos servidores públicos civis, a Constituição de 1988, no artigo 37, inciso XII, estendeu o direito de greve, porém deixou a cargo da legislação específica os limites de seu exercício.

O direito de greve dos servidores públicos civis é reconhecido pelo art. 37, VII, da Constituição Federal e estabelece que:

"Art. 37. A administração pública direta e indireta de qualquer dos Poderes da União, dos Estados, do Distrito Federal e dos Municípios obedecerá aos princípios de legalidade, impessoalidade, moralidade, publicidade e eficiência e, também, ao seguinte: (Redação dada pela Emenda Constitucional $n^{\circ} 19$, de 1998) (...)

VII - o direito de greve será exercido nos termos e nos limites definidos em lei específica; (Redação dada pela Emenda Constitucional $n^{\circ} 19$, de 1998) (... $)^{1350}$

\footnotetext{
${ }^{346}$ SILVA, Walküre Lopes Ribeiro da. A disciplina jurídica da greve e as constituições republicanas no Brasil, cit., p. 151.

${ }^{347}$ ANTUNES, Ricardo. A rebeldia do trabalho: o confronto operário do ABC Paulista: as greves de 1978/80. 2. ed. Campinas: Ed. da Uniamp, 1992. p. 167.

${ }^{348}$ CONSTITUIÇÃO DA REPÚBLICA FEDERATIVA DO BRASIL DE 1988, cit.

${ }^{349}$ SILVA, Walküre Lopes Ribeiro da. A disciplina jurídica da greve e as constituições republicanas no Brasil, cit., p. 152.

${ }^{350}$ CONSTITUIÇÃO DA REPÚBLICA FEDERATIVA DO BRASIL DE 1988, cit.
} 
A redação original usava o termo lei complementar ao invés de lei específica. É importante ressaltar que para a aprovação de uma lei complementar à Constituição é necessário um “quorum especial de votação no Congresso Nacional, difícil de ser obtido, e até hoje muito poucas foram as leis complementares aprovadas. Da referida regulamentação do direito de greve não se fala nem se cogita, e provavelmente muito tempo decorrerá até que venha a ser discutida a regulamentação da greve dos servidores públicos civis, se é que algum dia isso ocorrerá". 351

Já os servidores públicos militares, por sua vez, foram excluídos do direito de greve, conforme previsto no artigo 42, parágrafo $5^{\circ}$. A Lei n. 7.783 , de 28 de junho de 1989, regula o direito de greve para os trabalhadores do setor privado da economia.

Quanto aos servidores públicos militares, a Constituição Federal não reconhece o direito de sindicalização nem o direito de greve aos militares, definidos pelo art. 142, § 3. , da CF/88 como os membros das Forças Armadas, sendo que, de acordo com o art. 42, caput, da CF/88, são militares dos Estados, municípios e do Distrito Federal os membros das polícias militares e dos corpos de bombeiros militares.

“Art. 142,\$3.", IV - ao militar são proibidas a sindicalização e a greve; (Incluído pela Emenda Constitucional $n^{\circ} 18$, de 1998)"352

Esta vedação constitucional encontra respaldo na idéia de que os militares estão organizados com base na hierarquia e na disciplina. Também em outros países ocorre a mesma proibição. De forma que, qualquer outra manifestação coletiva dos militares estaria contrariando a hierarquia militar e afetando a coesão interna dessa instituição.

A respeito da negativa do direito de greve às forças armadas e à policia militar: "O fundamento desta posição negativa é naturalmente, o de que os serviços se confundem inteiramente com funções típicas do Estado, constituindo meios de exercício da soberania." 353

No entanto, aos policiais civis é permitida a realização de greve, o que está perfeitamente de acordo com o entendimento da OIT a respeito da matéria, que deixa a critério de cada país restringir ou não o direito de greve desses trabalhadores.

\footnotetext{
${ }^{351}$ GIGLIO, Wagner D. Brasil: trabajadores del Estado em Iberoamerica, cit., p. 67.

${ }^{352}$ CONSTITUIÇÃO DA REPÚBLICA FEDERATIVA DO BRASIL DE 1988. Disponível em: <http://www.planalto.gov.br/ccivil_03/Constituicao/Constitui\%C3\%A7ao.htm>. Acesso em: 15 jan. 2009.

${ }^{353}$ FERNANDES, António Monteiro. op. cit., p. 75.
} 
Muito embora haja a previsão no texto constitucional da edição de uma lei específica sobre o direito de greve do servidor público, até hoje não foi editada a referida lei, o que, para alguns, impediria o exercício do direito de greve pelos servidores públicos civis. Registre-se que antes da Emenda Constitucional n. 19, era lei complementar, posteriormente lei específica.

Em razão da discordância sobre a possibilidade do exercício do direito de greve dos servidores públicos, os tribunais passaram a ser questionados sobre a matéria. Mais adiante trataremos do posicionamento deles em relação ao que estabelece a Constituição Federal de 1988.

\subsubsection{Investigação sobre as causas das greves no serviço público}

Robertônio Santos Pessoa menciona as três principais causas apontadas para as greves no serviço público: (i) remuneração; (ii) redução no quadro do pessoal ou privatização; (iii) ausência de mecanismos institucionais ou informais de consulta e negociação no serviço público. ${ }^{354}$

Numa análise geral do fenômeno da greve na América Latina, além daquelas que acontecem no serviço público, observa-se que elas têm origem freqüentemente, "na ineficiência dos sistemas estabelecidos para negociar para prevenir ou solucionar conflitos. Ao nível da empresa, ter-se-ia também que apontar a ausência generalizada de canais de comunicação e de participação, que permitam às partes identificar e solucionar os problemas não resolvidos acumulam-se e dão lugar a tensões e frustrações, que eclodem por ocasião da negociação coletiva, ou a propósito de algumas reclamações não atendidas. São incontáveis as greves verificadas na região por uma simples demissão ou por um tratamento inadequado das relações humanas, questões que poderiam ser resolvidas com uma administração de pessoal adequada. A greve age, nestas condições, como um substitutivo da administração de pessoal, e constitui, em si mesma, um meio de solução de conflitos." 355

\footnotetext{
${ }^{354}$ PESSOA, Robertônio Santos. op. cit., p. 75-76.

${ }^{355}$ CÓRDOVA, Efrén; MORGADO, Emilio. A greve e o fechamento patronal. As relações coletivas de trabalho na América Latina: um estudo de seus atores, suas diversas manifestações e seus conflitos, com especial referência ao setor privado, publicado sob a direção de Efrén Córdova; trad. Maria Jacobson, São Paulo: LTr ; IBRART; Genebra: Organização Internacional do Trabalho, 1985. p. 301.
} 
A existência de problemas econômicos e financeiros enfrentados por muitos países tem obrigado a adoção de medidas rigorosas em relação à política físcal e orçamentária, o que afeta diretamente as decisões quanto aos gastos com pessoal e até mesmo restrições em relação aos gastos públicos em geral por meio de medidas que visam o controle dos gastos públicos, como no caso brasileiro, a Lei Complementar 101, de 4 de maio de 2000, que estabelece normas de finanças públicas voltadas para a responsabilidade na gestão físcal. Em meio a essa realidade, a redução do quadro de servidores tem sido utilizada como fator de contenção dos gastos, o que propicia a presença de figuras como a terceirização de alguns setores, como o de limpeza e vigilância, assim como, as privatizações, com impactos importantes nas relações coletivas de trabalho dos servidores públicos.

Muitos conflitos ocorridos no setor público têm origem nas dificuldades orçamentárias das administrações públicas em decorrência da recessão econômica prolongada. Muitas vezes, para satisfazer as condições impostas por organismos financeiros internacionais como o Fundo Monetário Internacional e o Banco Mundial, as administrações públicas reduzem os gastos públicos por meio das restrições do número de trabalhadores ou da remuneração destes. Além disso, agravam as tensões entre servidores públicos e administração a nova orientação, segundo a qual, abandonam-se os ideais do Estado assistencial, que tinha como objetivo assegurar o bem-estar, em troca de uma postura neoliberal, que limita a intervenção estatal no que diz respeito a assuntos sociais. Outros conflitos entre os servidores a administração pública surgem como conseqüência de medidas como privatização ou subcontratação de certos segmentos junto ao setor privado. $^{356}$

É muito freqüiente a ocorrência de greves no setor público com a finalidade de forçar uma negociação com a administração pública, chega inclusive a ser considerado um tipo clássico de conflito trabalhista. ${ }^{357}$

Se levarmos em consideração que a negociação coletiva pode ser considerado um dos principais meios para resolver os conflitos de trabalho, ${ }^{358}$ negá-la aos servidores públicos não contribui para a pacificação social, pois muitas greves poderiam ser evitadas ou mesmo ter um caráter mais brando caso houvesse espaço para a negociação.

\footnotetext{
${ }^{356}$ OZAKI, M. op. cit., p. 472.

${ }^{357}$ Id. Ibid., p. 473.

${ }^{358}$ Id., loc. cit.
} 


\subsubsection{O debate acerca da greve dos servidores públicos}

A noção de conflito coletivo, embora tenha sido elaborada com base na realidade dos trabalhadores do setor privado, na qual se verificam os embates entre o capital e o trabalho, também é plenamente aplicável ao setor público. ${ }^{359}$ Mesmo porque, na prática, verifica-se, freqüentemente, a existência de muitos conflitos sobre as condições de trabalho entre administração pública e os seus servidores.

A greve dos servidores públicos tem sido tradicionalmente proibida ou restringida, principalmente, sob a alegação de que ela interfere na necessidade de continuidade da prestação dos serviços públicos. ${ }^{360}$ Entre os diversos argumentos contrários à greve dos servidores públicos destacam-se aqueles que têm como fundamento: (i) a natureza dos serviços prestados pelos poderes públicos; (ii) o caráter da relação entre o Estado e os seus servidores. ${ }^{361}$

O primeiro deles justifica a proibição ou limitação da greve devido ao caráter essencial dos serviços prestados pelo Estado para toda a coletividade, devendo, portanto, serem prestados sem interrupção. Esse ponto de vista faz com que, muitas vezes, os serviços públicos sejam tratados como serviços essenciais, muito embora nem todos eles tenham esse caráter, conforme veremos mais adiante ao tratarmos especificamente do tema greve nos serviços essenciais.

Como ressalta Odete Medaur, por muito tempo os ordenamentos jurídicos de uma forma geral proibiram a greve de servidores públicos, sobretudo, em razão do princípio da continuidade do serviço público. Pretendia-se, portanto, impedir interrupções na prestação do serviço. $^{362}$

José Cretella Jr justificava a proibição alegando que o serviço público “é informado por vários princípios, dentre os quais o princípio de continuidade, pelo qual se garante à coletividade o fornecimento constante das vantagens atribuídas. Por esse motivo, além de outros, é vedada a greve do funcionário público, o que acarretaria a paralisação dos serviços, a quebra da continuidade, com irreparáveis prejuízos para o Estado e para os

\footnotetext{
${ }^{359}$ PESSOA, Robertônio Santos. op. cit., p. 63.

${ }^{360}$ LÓPEZ-MONÍS DE CAVO, Carlos. op. cit., p. 19.

${ }^{361}$ PESSOA, Robertônio Santos. op. cit., p. 75.

${ }^{362}$ MEDAUAR, Odete. op. cit., p. 279.
} 
administrados". ${ }^{363}$ Essa justificativa, embora tenha um peso considerável, uma vez que a não interrupção é um dos corolários da natureza do serviço público, não é suficiente para afastar a possibilidade de greve neste setor. É plenamente compatível a paralisação, desde que sejam tomadas medidas preventivas como aviso prévio e a manutenção de plantões, entre outras. ${ }^{364}$

O segundo argumento, por sua vez, trata do caráter unilateral da relação entre o servidor e o ente público para o qual o serviço é prestado, baseada na posição superior hierárquica do Estado como poder soberano, sem levar em consideração a dissociação entre a figura do Estado como empregador e como ente dotado de poder soberano.

A situação dos ordenamentos jurídicos que não reconhecem o direito de greve dos servidores públicos, segundo António Monteiro Fernandes, "corresponde à subsistência da concepção segundo a qual a posição do funcionário é especialmente marcada por traços de 'fidelidade' e de 'serviço', exercendo funções inerentes à concretização da autoridade estadual, num regime que não é contratual mas estatutário (...) É justamente essa concepção que, entre nós, com o reconhecimento da liberdade sindical, do direito de negociação coletiva e do direito de greve, se tem que considerar atualmente ultrapassada, ou, ao menos, fortemente atenuada., 365

Além dessas justificativas, a proibição da greve no serviço público era explicada por outras razões ${ }^{366}$, entre elas: a prevalência do interesse público sobre o interesse dos grupos profissionais; a da legalidade do regime do servidor público; a inexistência da finalidade de lucro por parte dos entes públicos.

O interesse público é um dos desdobramentos do principio da continuidade de serviço público, ou seja, o interesse público, representado pela continuidade dos serviços públicos, segundo este argumento, deve prevalecer em relação aos interesses dos trabalhadores desse setor defendidos por meio da greve. No entanto, argumenta-se em contrapartida que o exercício do direito de greve não representa somente a defesa dos interesses dos particulares, mas "também uma liberdade que constitui direito fundamental e que, como tal, é patrimônio comum de todos os cidadãos. É este aspecto da greve que a justifica e acaba por reconhecer-lhe eficácia, inclusive na esfera da administração pública, exceto quando atingidos direitos que devam ter prioridade sobre o direito de greve, num

\footnotetext{
${ }^{363}$ CRETELLA JÚNIOR, José. Curso de liberdades públicas. São Paulo: Rio de Janeiro, 1986.

${ }^{364}$ MAGANO, Octavio Bueno. Direito coletivo do trabalho, cit., p. 200.

${ }^{365}$ FERNANDES, António Monteiro. op. cit., p. 74.

${ }^{366}$ MAGANO, Octavio Bueno. Direito coletivo do trabalho, cit., p. 199.
} 
caso concreto (...) num ordenamento jurídico democrático, não se pode tutelar um interesse em abstrato, nem sequer o 'interesse público’, sem que tenha sido concretizado em direito constitucionalmente estabelecido. Ao contrário, a exceção converter-se-á em regra geral". 367

Além disso, o interesse público não é sinônimo de interesse da administração pública, porém é freqüente o uso da justificativa de que deve haver a prevalência do interesse público sobre o interesse dos trabalhadores do setor público, quando na verdade se pretende mascarar um interesse da administração pública. É importante ressaltar que não há uma identidade necessária entre função pública e interesse público, pois "nem todos os funcionários, pelo simples fato de sê-lo, desempenham funções essenciais para o interesse geral". 368

$\mathrm{O}$ argumento de que a legalidade do regime do servidor torna ineficaz a greve como instrumento de modificação das condições de trabalho desse grupo de trabalhadores não é um elemento impeditivo do exercício desse direito, pois, nos regimes democráticos e dotados de pluralidade, o Estado não deve ser autoritário, mas fazer uso do contrato no lugar do estatuto. ${ }^{369}$

Quanto à última razão, aquela que justifica a limitação do exercício do direito de greve dos servidores públicos em razão da inexistência da finalidade de lucro por parte dos entes públicos, também não afasta a possibilidade de exercício de tal direito. Na medida em que o Estado passou a envolver-se cada vez mais em atividade de natureza econômica, estes argumentos perderam muito de sua força. ${ }^{370}$ Esta nova realidade permitiu aos servidores compararem a sua situação com a dos empregados públicos e almejar a mesma condição.

Ainda, outro argumento freqüentemente utilizado como elemento impeditivo do direito de greve no interior da administração pública é a natureza estatutária da relação jurídica entre eles e o Estado, o que acarreta: (i) a inexistência de conflito, baseada no princípio de contradição de que ninguém pode ir contra si mesmo; (ii) a presença do princípio da hierarquia administrativa; (iii) o reconhecimento da posição de supremacia

\footnotetext{
${ }^{367}$ LÓPEZ-MONÍS DE CAVO, Carlos. op. cit., p. 20.

${ }^{368}$ Id., loc. cit. p. 20.

${ }^{369}$ MAGANO, Octavio Bueno. Direito coletivo do trabalho, cit., p. 200.

${ }^{370}$ Id. Ibid., p. 200.
} 
jurídica da administração na sua relação com os servidores públicos; (vi) a falta de contratação coletiva na administração. ${ }^{371}$

A inexistência de interesses em conflito entre o servidor e a administração pública é defendida com base na presença de "dupla identificação entre o Estado-Poder Público e o Estado-patrão, e entre o funcionário-agente que executa a vontade soberana do Estado e o funcionário-servidor do Estado", sendo assim, com a aplicação do princípio de contradição a greve não se justificaria, uma vez que ninguém pode ir contra si mesmo. ${ }^{372}$

No entanto, a relação entre ambos, quando vista de uma perspectiva realista e não aquela puramente jurídico-positivista, admite sim o conflito, pois trata-se de uma relação de trabalho profissional, uma vez que o servidor público presta habitualmente trabalho para, em contrapartida obter o seu sustento, o que pressupõe a existência de uma distinção entre os interesses de natureza profissional, por parte dos servidores, e o interesse da administração pública, o que desfaz a mítica identificação entre servidores e administração pública. $^{373}$

O princípio da hierarquia administrativa, por sua vez, justificaria a proibição da greve, pois os servidores públicos que ocupassem cargos inferiores deveriam respeitar as ordens de seus superiores e esse dever de obediência seria incongruente com a atuação do sindicato ao declarar a greve. Contudo, a greve não incide na prestação individualizada de trabalho, mas na relação coletiva por meio do sindicato, com isso não se altera o liame hierárquico de subordinação presente na administração pública. ${ }^{374}$

O reconhecimento da posição de supremacia da administração na relação de natureza jurídico-pública entre o servidor e a administração pública é outra justificativa para a inviabilidade da greve neste setor. O servidor público está submetido à lei na figura do respectivo estatuto e a greve seria um ato de rebelião contra o Estado e, sobretudo, contra atos legítimos do parlamento. No entanto, a greve não é incompatível com a soberania do Estado, uma vez que essa soberania compreende também a competência para compartilhar a autoridade, com o reconhecimento do direito de greve dos servidores como estratégia em matéria de administração de pessoal. ${ }^{375}$

\footnotetext{
${ }^{371}$ LÓPEZ-MONÍS DE CAVO, Carlos. op. cit., p. 20-24.

${ }^{372}$ Id. Ibid., p. 21.

${ }^{373}$ Id. Ibid., p. 22.

${ }^{374}$ Id. loc. cit.

${ }^{375}$ Id. Ibid., p. 22-23.
} 
A falta de contratação coletiva na administração pública também é alegada como uma decorrência da natureza estatutária da relação da administração com os servidores públicos e, conseqüentemente, como fator que inviabiliza a greve dos servidores. Porém, a falta de contratação coletiva na administração não inviabiliza a greve, pois esta serve como instrumento de pressão para que as negociações coletivas ocorram, mesmo que em caráter consultivo e de apresentação de propostas para o legislativo. ${ }^{376}$

É evidente que a greve no setor privado causa dano ao empregador ao impingir a este um prejuízo econômico, uma vez que elas são direcionadas a quem aufere lucro com o trabalho prestado. Em contrapartida, no serviço público esse dano também ocorre, no entanto, os prejuízos econômicos, quando ocorrem, são suportados por toda a sociedade, pois, sendo o Estado o empregador não há fim lucrativo. Os usuários dos serviços públicos são, segundo essa linha de argumentação, prejudicados duplamente, pela ausência da prestação do serviço e pelo eventual aumento de impostos direcionados aos contribuintes como forma de equilibrar as contas públicas.

Isso faz com que surjam argumentos contrários ao direito de greve dos servidores públicos que se apegam à falta de funcionalidade no caso concreto. No entanto, é importante lembrar que a greve neste caso, se não vem acompanhada de um prejuízo econômico, redunda em um desgaste político para o Estado. ${ }^{377}$ Além disso, não se pode admitir que a sociedade possa agir de forma a explorar um grupo de trabalhadores, pois os servidores públicos não são privilegiados, são apenas assalariados que contam com os seus vencimentos para o seu sustento e o da sua própria família. É salutar a toda a sociedade, lutar contra qualquer forma de injustiça, principalmente, aquelas relativas às condições de trabalho.

\subsubsection{Posições doutrinárias e jurisprudências em relação ao direito de greve dos servidores públicos na Constituição de 1988}

Em relação ao que dispõe a Constituição Federal de 1988, a doutrina diverge quanto à possibilidade do exercício do direito de greve no setor público. Os posicionamentos variam muito. Parte da doutrina considera que esse direito somente

\footnotetext{
${ }^{376}$ LÓPEZ-MONÍS DE CAVO, Carlos. op. cit., 23-24.

${ }^{377}$ NASCIMENTO, Amauri Mascaro. Compêndio de direito sindical, cit., p. 454.
} 
poderá ser exercido mediante a existência de lei específica, enquanto que outra assegura ser possível o seu exercício, aplicando-se a lei de greve do setor privado enquanto não sobrevier a lei específica ${ }^{378}$.

A respeito do dispositivo que prevê o direito de greve dos servidores públicos, Celso Antônio Bandeira de Mello assevera que "este é exercitável desde logo, antes mesmo de editada a sobredita lei complementar ${ }^{379}$, que lhe estabelecerá os limites. Trata-se de norma de eficácia contida, segundo a terminologia adotada por José Afonso da Silva ${ }^{380}$ (...) advirta-se, apenas, que a greve não poderá deixar sem atendimento as 'necessidades inadiáveis' da comunidade, a serem identificadas segundo um critério de 'razoabilidade', pois a obrigação de suprimi-las está constitucionalmente prevista, até mesmo para os trabalhadores em geral, conforme $\S 1^{\circ}$ do art. $9^{\circ}$ ", 381

Arion Sayão Romita afirma que "condicionar o exercício do direito de greve à promulgação de lei complementar $^{382}$ significa privar o servidor público do exercício de um direito que a Constituição já lhe assegura, por ter revogado a proibição". 383

José Afonso da Silva ao analisar o direito de greve dos servidores públicos previsto na Constituição observa que "em tal caso, existe por força de norma constitucional, não por força de lei. Não é a lei que vai criar o direito. A Constituição já o criou. Nesses casos de norma de eficácia contida, a lei referida na norma, quando promulgada, é apenas restritiva ao direito reconhecido, não geradora desse direito. Isso significa que enquanto a lei não vem, o direito há que prevalecer em sua amplitude constitucional. Reforça essa tese o fato de a Constituição ter garantido aos servidores

\footnotetext{
${ }^{378}$ SANTOS, Enoque Ribeiro dos; SILVA, Juliana Araújo Lemos da. op. cit., p. 231.

${ }^{379}$ A redação original usava o termo lei complementar ao invés de lei específica. Esta última redação resulta da Emenda Constitucional n.19, relativa aos direitos dos servidores públicos.

${ }^{380}$ José Afonso da Silva na sua obra, Aplicabilidade das normas constitucionais, apresenta uma classificação segundo a qual as normas constitucionais podem ser agrupadas quanto à eficácia e aplicabilidade em: (i) normas de eficácia plena e aplicabilidade direita, imediata e integral; (ii) normas de eficácia contida e aplicabilidade direta e imediata, mas possivelmente não integral; (iii) normas de eficácia limitada, que podem ser subdivididas em: (a) normas declaratórias de princípios institutivos ou organizativos e (b) normas declaratórias de princípio programático. Conforme: SILVA, José Afonso da. Aplicabilidade das normas constitucionais. 7.ed. São Paulo: Malheiros Ed., 2007. p. 85-86.

${ }^{381}$ MELLO, Celso Antônio Bandeira de. Regime Constitucional dos servidores da administração direta e indireta, cit., p. 77-78.

${ }^{382}$ É importante observar que antes da Emenda Constitucional n. 19 a redação do inciso VII do artigo 37 da Constituição Federal era o seguinte: "o direito de greve será exercido nos termos e limites definidos em lei complementar".

${ }^{383}$ ROMITA, Arion Sayão. op. cit., p. 808.
} 
públicos amplo direito à livre associação sindical (art. 37, VI) que implica, só por si, o direito à greve. Então, se a lei não vem, o direito existe, e se existe, pode ser exercido". ${ }^{384}$

Enoque Ribeiro dos Santos e Juliana Araújo Lemos da Silva, a respeito do direito de greve do servidor público previsto no artigo 37, VII da Constituição Federal, entendem "ser ele perfeitamente exercitável não apenas pelo empregado público das empresas públicas e sociedades de economia mista que desenvolvem atividades econômicas, mas extensível ao funcionário público (estatutário), já que se trata de norma de eficácia contida ou restringível (...) o direito de greve dos servidores públicos, tanto dos empregados públicos como dos funcionários públicos (estatutários) têm aplicabilidade plena, integral, imediata, que, todavia, poderá ter sua eficácia ou alcance reduzido, no futuro, pelo advento de uma lei específica infraconstitucional”. 385

Raimundo Simão de Melo considera que "enquanto não for promulgada a lei específica a que se refere o art. 37, inciso VII, da Constituição, o servidor público civil poderá exercer o direito de greve, aplicando-se por analogia, a referida Lei n. 7.783/89. Caso contrário, estar-se-á negando esse direito fundamental do cidadão, assegurado pela Lei Maior". O autor adverte que "a única hipótese em que o constituinte quis negar esse direito o fez expressamente, como é o caso do servidor público militar (art. 142, inciso IV)". 386

O posicionamento do STJ é no sentido do reconhecimento do exercício do direito de greve dos servidores públicos civis, mesmo ausente lei regulamentadora. ${ }^{387}$ No entanto, o STF tomou outro posicionamento ao julgar Ações Diretas de Inconstitucionalidade e Mandados de Injunção, conforme veremos a seguir.

O STF, no julgamento de Ações Diretas de Inconstitucionalidade, declarou a inconstitucionalidade de preceitos legais que reconheciam aos servidores públicos o direito

\footnotetext{
${ }^{384}$ SILVA, José Afonso da. Curso de direito constitucional positivo. 28. ed. São Paulo: Malheiros Ed., 2007. p. 700.

${ }^{385}$ SANTOS, Enoque Ribeiro dos; SILVA, Juliana Araújo Lemos da. op. cit., p. 231.

${ }^{386}$ MELO, Raimundo Simão de. A greve no direito brasileiro. São Paulo: LTr, 2006. p. 54.

${ }^{387}$ Conforme o STJ - ROMS 2947 / SC; Recurso Ordinário em Mandado de Segurança- 1993/0011022-5 Min. Adhemar Maciel (1099) sexta turma- DJ data:16/08/1993 p. 15996, o direito de greve foi considerado "norma de eficácia contida", ou seja, "a lei complementar estabelecerá limites para o exercício do direito de greve, embora não possa dificultá-lo excessivamente. Mas, enquanto não vierem tais limitações, o servidor público poderá exercer seu direito. Não fica jungido ao advento da lei complementar regulamentadora".
} 
de greve e de negociação coletiva ${ }^{388}$ e costumava conceder Mandando de Injunção sobre a matéria. ${ }^{389}$

Nestes últimos casos, a posição do STF era no sentido de considerar o direito de greve uma norma de eficácia meramente limitada, por isso não auto-aplicável e dependente da edição de uma lei que regulamentasse o direito em questão. Com essa posição o STF consagrou a idéia de que a norma constitucional que assegurou o direito de greve no serviço público não era auto-aplicável, o que, na prática, significava dizer que o direito de greve estava na dependência de norma infraconstitucional que estipulasse os limites de seu exercício.

Apesar disso, não era pacífica no STF a idéia de ser o Mandado de Injunção necessário para o exercício do direito de greve, como é possível verificar no seguinte trecho do voto vencido proferido pelo Ministro Sepúlveda Pertence no MI n. ${ }^{\circ}$ 585-9/TO:

\begin{abstract}
"Se se reconhece quer a existência de uma lei específica, quer, no ordenamento infraconstitucional, a possibilidade de aplicação por analogia ou por interpretação extensiva de uma outra lei existente, então, o exercício do direito constitucional invocado não está obstado pela falta de norma regulamentar e falta interesse de agir para o mandado de injunção. Desse modo, já decidimos em várias outras hipóteses. Por isso, peço vênia a todos, particularmente ao Sr. Ministro Carlos Velloso, para, malgrado concordando com a fundamentação do seu voto, não conhecer do Mandado de Injunção."
\end{abstract}

Ao reconhecer a omissão do Poder Legislador, o STF somente notificava tal poder para que agisse de forma a concretizar o direito constitucional ora em análise, resultando na espera de fazer valer esse direito fundamental.

Atualmente a posição do STF apontou em outro sentido, pois ao julgar dois Mandados de Injunção sobre o direito de greve do servidor público o entendimento passou a ser diverso. Os Mandados de Injunção n. 670-ES e n. 712- PA abrem um novo paradigma, caminhando-se para um verdadeiro divisor de águas entre o velho e o novo

\footnotetext{
${ }^{388}$ Conforme ADIN 492-1/DF, Rel. Min. Carlos Veloso in DJ 12.03.1993 e ADIN 335-6/RJ, Rel. Min. Néri da Silveira in DJ 2.4.1993.

${ }^{389}$ Conforme STF- MI 20-4/DF - Rel. Min. Celso de Mello - DJ 22.11 .96 "o preceito constitucional que reconheceu o direito de greve ao servidor público civil constitui norma de eficácia meramente limitada, desprovida, em conseqüência, de auto-aplicabilidade, razão pela qual, para atuar plenamente, depende da edição da lei complementar exigida pelo próprio texto da Constituição. A mera outorga constitucional do direito de greve ao servidor público civil não basta - ante a ausência de auto-aplicabilidade da norma constante do art. 37, VII, da Constituição - para justificar o seu imediato exercício”. O STF - MI 485/MT Rel. Min. Maurício Corrêa - Julgamento 25.04.2002 - Pleno - DJ em 23.08.2002, que julgou pela impossibilidade de aplicação dos métodos de integração da norma, em face da lacuna legislativa, por ser hipótese, não de existência de lei omissa, mas de ausência de norma reguladora específica.
} 
entendimento do STF. O primeiro Mandado de Injunção, de número 670, foi ajuizado pelo Sindicato dos Servidores Policiais Civis do Espírito Santo e pretende assegurar aos seus filiados o exercício do direito de greve. O segundo, de número 712, foi impetrado pelo Sindicato dos Trabalhadores do Poder Judiciário do Pará pelo mesmo motivo.

O Supremo Tribunal Federal declarou a omissão do Congresso Nacional em relação à necessidade de aprovar a lei que regulamente o direito de greve no serviço público. Além disso, determinou a aplicação das normas vigentes no setor privado, enquanto o Poder Legislativo não aprovar uma lei específica para os servidores públicos. Antes, ao julgar esse tipo de processo, o Supremo se limitava a declarar a omissão do Congresso, o que tornava o mandado de injunção inócuo. Desta vez, porém, os ministros definiram a norma que irá vigorar durante a ausência da lei. ${ }^{390}$

Mesmo com a nova posição do STF, que decidiu que na falta de lei específica os servidores devem seguir as regras aplicadas aos trabalhadores da iniciativa privada, é importante criá-la. No entanto, deve-se observar que qualquer norma que regule a questão não pode restringir esse direito de forma a torná-lo inexistente, impedindo, na prática, o seu exercício.

Os inúmeros limites impostos ao direito de greve podem ser apresentados em uma escala crescente de gravidade que vão da simples necessidade de pré-aviso, seguida da plena liberdade de exercício de greve, até a proibição absoluta da greve, sem que seja oferecido aos trabalhadores um meio alternativo de obter justiça. Entre esses pólos podemos ter: a investigação sobre a controvérsia por parte da autoridade pública; a obrigatoriedade de tentativa de conciliação, sem proibição da greve, mas com impedimento de exercê-la enquanto durar tal procedimento; a obrigatoriedade de arbitragem, sem proibição da greve, mas com impedimento de exercê-la enquanto durar tal procedimento; a faculdade de intervenção da autoridade pública para decidir sobre a proibição da greve, conforme o caso concreto; a proibição absoluta da greve e submissão da controvérsia a decisão de tribunal arbitral; a proibição absoluta da greve e submissão da controvérsia a

\footnotetext{
${ }^{390}$ A ementa do acórdão do MI 670/ES julgado em 25/10/2007, cujo relator foi o Ministro Gilmar Mendes assim estabeleceu: "Mandado de Injunção. Garantia Fundamental (CF, art. $5^{\circ}$.inciso LXXI). Direito de greve dos servidores públicos civis (CF, art. 37, inciso VII). Evolução do tema na jurisprudência do Supremo Tribunal Federal (STF). Definição dos parâmetros de competência constitucional para apreciação no âmbito da Justiça Federal e da Justiça Estadual até a edição da legislação específica pertinente, nos termos do art. 37, VII, da CF. Em observância aos ditames da segurança jurídica e à evolução jurisprudencial na interpretação da omissão legislativa sobre o direito de greve dos servidores públicos civis, fixação do prazo de 60 (sessenta) dias para que o Congresso Nacional legisle sobre a matéria. Mandado de Injunção deferido para determinar a aplicação das leis n. 7.701/1988 e 7.783/1989”.
} 
decisão de tribunal trabalhista. Sendo assim, a proibição pode ser temporária, isto é, somente enquanto exaurirem os procedimentos de conciliação e arbitragem, não impondo às partes qualquer decisão, podendo, posteriormente gozar do direito de greve, ou definitiva, porém com o oferecimento de meios de solução do conflito seja a conciliação, a arbitragem ou o judicial. Este último figura como uma profunda intervenção do Estado na regulamentação das condições de trabalho. ${ }^{391}$

Odete Medauar observa que na maioria dos ordenamentos estrangeiros, mediante lei ou na ausência de lei, duas medidas em especial vêm sendo adotadas, visando conciliar o direito de greve do servidor e a continuidade das atividades administrativas: comunicação prévia e manutenção de um percentual de funcionamento do serviço. ${ }^{392}$

Robert Alexy afirma que, de acordo com a teoria externa, "o conceito de restrição a um direito sugere duas coisas - o direito e sua restrição -, entre as quais há uma relação de tipo especial, a saber, uma relação de restrição. Se a relação entre direito e restrição for definida dessa forma, então, há, em primeiro lugar, o direito em si, não restringido, e, em segundo lugar, aquilo que resta do direito após a ocorrência de uma restrição, o direito restringido. (...) Um cenário completamente diferente é a base de sustentação da teoria interna. Segundo ela, não há duas coisas - o direito e sua restrição -, apenas uma: o direito com um determinado conteúdo. O conceito de restrição é substituído pelo conceito de limite. Dúvidas acerca dos limites do direito não são dúvidas sobre quão extensa pode ser sua restrição, mas dúvidas sobre seu conteúdo. Quando eventualmente se fala em 'restrições' no lugar de 'limites', então, se fala em 'restrições imanentes'., 393

É importante ressaltar que a limitação ou restrição ao direito de greve dos servidores públicos deve ser considerada uma medida grave por tratar-se de um direito humano fundamental, conforme veremos oportunamente, sendo feita com parcimônia para não descaracterizá-lo como tal.

Deixar para o campo da discricionariedade também não é a melhor solução. Apesar de na grande maioria dos países ter havido uma grande mudança, na medida em que, hoje, se reconhece cada vez mais as obrigações do Estado como empregador, existe uma tendência por parte do Estado de, em situações extremas, tentar manter uma situação mais vantajosa frente a conflitos entre a administração e o sindicato dos servidores

\footnotetext{
${ }^{391}$ BRIOSCHI, Gian Antonio; SETTI, Federico. op. cit., p. 76.

${ }^{392}$ MEDAUAR, Odete. op. cit., p. 280.

${ }^{393}$ ALEXY, Robert. Teoria dos direitos fundamentais. Trad. Virgílio Afonso da Silva. São Paulo: Malheiros Ed., 2006. p. 277-278
} 
públicos. Há, portanto, um perigo do Estado tentar usar seu poder soberano para afastar a oposição sindical. ${ }^{394}$

\subsubsection{Serviços essenciais}

O estudo da greve nos serviços essenciais e no serviço público, por vezes, é tratado de forma unitária, sobretudo, quando os primeiros forem prestados pelo Estado, situação em que é evidente a presença de pontos em comum. Também, como elemento de intersecção, é alegada a natureza dos dois serviços, que tem no seu âmago a exigência de continuidade para não acarretar prejuízo para a coletividade. No entanto, pode haver uma análise em separado resultando em conclusões próprias e autônomas. ${ }^{395}$

Antes de qualquer coisa é importante uma atenção especial para o real significado dos termos. A palavra essencial denota algo indispensável, necessário, importante, fundamental. ${ }^{396}$ Desta forma, para uma determinação de quais são os serviços essenciais, não podemos nos ater a aspectos subjetivos, mas sim, tratarmos a questão com objetividade. O julgamento daquilo que é essencial deve levar em consideração toda a coletividade, e não indivíduos isolados.

A definição de serviços essenciais foi se tornando ao longo do tempo cada vez mais restritiva, pois antes o entendimento do Comitê de Liberdade Sindical era no sentido de que serviços essenciais consistiam naqueles cuja interrupção poderia acarretar prejuízos públicos ou graves prejuízos à coletividade. Posteriormente, nos finais dos anos 70, o Comitê de Liberdade Sindical definiu os serviços essenciais como aqueles que, se interrompidos, poderiam colocar em perigo a vida ou as condições normais de existência de toda ou de parte da população. ${ }^{397}$ Desde 1983, a Organização Internacional do Trabalho, por meio do Comitê de Liberdade Sindical, delimita os serviços essenciais entre aqueles cuja interrupção pode trazer algum perigo a vida, a segurança ou a saúde de um grupo ou de todos os cidadãos. Sendo assim, descarta-se a possibilidade de um simples incômodo

\footnotetext{
${ }^{394}$ OZAKI, M. op. cit., p. 474.

${ }^{395}$ NASCIMENTO, Amauri Mascaro. Compêndio de direito sindical, cit., p. 453.

${ }^{396}$ Ferreira, Aurélio Buarque de Holanda. Novo dicionário da língua portuguesa, 2a ed., 1986, 712.

${ }^{397}$ SILVA, Walküre Lopes Ribeiro da. Limites ao direito de greve no contexto democrático: a experiência da Organização Internacional do Trabalho, cit., p. 32.
} 
provocado por toda e qualquer alteração provocada por uma paralisação ser caracterizado como descontinuidade de serviço essencial. ${ }^{398}$

Entre aqueles que são contrários ao direito de greve dos servidores públicos é comum o argumento que sustenta que os serviços prestados pela administração pública são essenciais para a coletividade, sendo assim, qualquer interrupção na sua prestação, inclusive aquela ocasionada pelo movimento grevista, é considerada intolerável, uma vez que, diferentemente do setor privado, o serviço público é regido pelo imperativo da continuidade. $^{399}$

A confusão entre os dois conceitos também encontrou na legislação brasileira um elemento de sustentação e, explica, pelo menos do ponto de vista histórico, a resistência por parte de alguns em estabelecer uma distinção clara entre serviço público e serviço essencial.

O Decreto-lei n. 1.632 de 04 de agosto de 1978 previa um rol de serviços considerados essenciais, entre os quais: os serviços de água, esgoto, energia elétrica, petróleo, gás e outros combustíveis, bancos transportes, comunicações, carga e descarga, hospitais, ambulatórios, maternidades, farmácias e drogarias, assim como, por ato do Presidente da República, em indústrias de interesses da segurança nacional. Ao lado destes, os serviços públicos federais, estaduais e municipais, de execução direta, indireta, delegada ou concedida são igualmente considerados, pelo decreto-lei, serviços essenciais e de interesse da segurança nacional. ${ }^{400}$ No entanto, é evidente que podemos estar diante de um serviço público não essencial ou de um serviço essencial prestado por particulares.

Por outro lado, é importante considerar que "os defensores do direito de greve na administração pública sustentam que nem todos os servidores públicos exercem atividades essenciais, havendo, inclusive, um grande número de empregados no setor privado que prestam serviços bem mais importantes para a coletividade do que certas categorias de funcionários públicos. Propõe-se, assim, um tratamento jurídico diferenciado com base na essencialidade da função desempenhada por toda a categoria de servidores, em razão do que somente seria negado o direito de greve àquelas categorias cuja paralisação das

\footnotetext{
${ }^{398}$ NASCIMENTO, Amauri Mascaro. Compêndio de direito sindical, cit., p. 458-459.

${ }^{399}$ PESSOA, Robertônio Santos. op. cit., p. 75.

${ }^{400}$ MAGANO, Octavio Bueno. Direito coletivo do trabalho, cit., p. 191.
} 
atividades representasse perigo à vida, à segurança, à saúde ou outro interesse vital da população". 401

A limitação imposta aos servidores públicos no que tange ao direito de greve, seguindo um critério puramente subjetivo, nem sempre se afigura correto, pois quando se recorre a esse argumento ele vem agregado àquele que a justifica com base no caráter de interesse coletivo presentes neste setor. Porém, também não podemos esquecer que há empresas privadas que atuam numa área de utilidade pública, cuja atividade está relacionada com o fornecimento de bens e serviços necessários e indispensáveis à coletividade, o que nos leva a concluir que importa menos o sujeito que o objeto da prestadora, sendo oportuno a adoção do critério objetivo. ${ }^{402}$

Carlos López-Monís de Cavo adverte que "está claro que nem todos os funcionários públicos realizam funções essenciais cuja interrupção causa 'males irreparáveis' - mas 'simples transtornos' - para a comunidade, e estas situações não são freqüentes. Caberia referir-se, neste sentido, à velha distinção entre 'funcionários de autoridade' - os que exercem o poder público - e 'funcionários de gerência' - os que executam as ordens expedidas pelos funcionários de autoridade (...) em certas ocasiões, os trabalhadores subordinados da empresa privada cumprem funções mais essenciais para a vida nacional que as de certos funcionários públicos. Dentro da função pública nem todos os serviços são rigorosamente essenciais". 403

No ordenamento jurídico brasileiro, o direito de greve nos serviços essenciais é reconhecido. A Constituição Federal de 1988 assegura, em seu artigo 9ª a todos os trabalhadores o direito de greve, inclusive àqueles que exercem atividades essenciais. Em relação a estes últimos, de acordo com o $§ 1^{\circ}$, "a lei definirá os serviços ou atividades essenciais e disporá sobre o atendimento das necessidades inadiáveis da comunidade”.

A Lei n. 7.783 de 1989 apresenta um rol de serviços ou atividades consideradas essenciais em seu artigo 10, ou seja, são apresentados como serviços essenciais: "Itratamento e abastecimento de água; a produção e distribuição de energia elétrica, gás e combustíveis; II- assistência médica e hospitalar; III- distribuição e comercialização de medicamentos e de alimentos; IV- funerários; V- transporte coletivo; VI- captação e tratamento de esgoto e lixo; VII- telecomunicações; VIII- guarda, uso e controle de

\footnotetext{
${ }^{401}$ PESSOA, Robertônio Santos. op. cit., p. 75.

${ }^{402}$ BRIOSCHI, Gian Antonio; SETTI, Federico. op. cit., p. 75.

${ }^{403}$ LÓPEZ-MONÍS DE CAVO, Carlos. op. cit., p. 21.
} 
substâncias radioativas, equipamentos e materiais nucleares; IX- processamento de dados ligados a serviços essenciais; XI- controle de tráfico aéreo; compensação bancária." 404

De acordo com o artigo 13 da lei referida acima, a comunicação prévia das greves nos serviços essenciais aos usuários deve ocorrer com antecedência mínina de 72 (setenta e duas) horas a contar do início da paralisação.

Durante o período em que forem transcorridas greves nos serviços elencados no rol apresentado anteriormente, devem ser mantidas as prestações daqueles serviços indispensáveis para que sejam atendidas as necessidades inadiáveis da comunidade, conforme prevê o artigo 11, da mesma lei, cujo parágrafo único define como aquelas que coloquem em perigo iminente a sobrevivência, a saúde e a segurança da população.

Amauri Mascaro Nascimento lembra que "o conceito de indispensabilidade deve ser compreendido não em função das exigências da empresa mas das necessidades inadiáveis da comunidade" e complementa, afirmando que "a indispensabilidade dos serviços exigidos pela comunidade é conceito relacionado diretamente com o bem estar da população concebido de forma restrita ao atendimento das necessidades inadiáveis desta". 405

\footnotetext{
${ }^{404}$ DIREITOS DOS TRABALHADORES. Lei n. 7.783, de 28 de junho de 1989. Disponível em: $<$ http://www.pge.sp.gov.br/centrodeestudos/bibliotecavirtual/dh/volume\%20i/tralei7783.htm>. Acesso em 18 jan. 2009.

${ }^{405}$ NASCIMENTO, Amauri Mascaro. Comentários à lei de greve, cit., p. 114-115.
} 


\section{DIREITO DE GREVE DOS SERVIDORES PÚBLICOS NA ÓTICA DOS DIREITOS HUMANOS FUNDAMENTAIS}

A evolução dos direitos humanos pode ser melhor compreendida por meio do estudo do surgimento do direito positivo, uma vez que este é parte integrante do desenvolvimento do outro. O caminho trilhado pelo direito positivo até a aceitação da universalidade dos direitos humanos nos dá uma idéia do seu desenvolvimento progressivo. ${ }^{406}$ Razão pela qual podemos afirmar que "a história das relações coletivas de trabalho e dos direitos fundamentais do trabalhador seguramente confundem-se com própria história do Direito do Trabalho". ${ }^{407}$

Nesta história, o direito de greve, como instrumento de luta dos trabalhadores teve e continua a ter, embora com alguns reveses, uma importância fundamental, no sentido de promover a dignidade humana do trabalhador. Sendo assim, a proteção do direito de greve, em geral, e o direito de greve dos servidores públicos, em particular, garantem a efetivação dos direitos humanos.

Antes de prosseguirmos na discussão referente ao direito de greve dos servidores públicos como direito humano fundamental é indispensável estudarmos os conceitos e as características dos direitos humanos, assim como, entendermos a contextualização quanto ao seu processo de construção ao longo da existência humana. Porém, cabem algumas considerações sobre a terminologia utilizada nos textos doutrinários e normativos para melhor elucidação do tema tratado.

\subsection{Terminologia}

Tanto na doutrina como no direito positivo, constitucional e internacional, há uma diversidade semântica que foi colecionada durante a evolução dos direitos humanos. ${ }^{408}$ Existe uma gama variada de expressões largamente utilizadas tais como: "direitos

${ }^{406}$ CAVALCANTI, Carlos André Macêdo; SIMÕES, Daniel; PEIXOTO, Edson; COSTA, Moisés. História moderna dos direitos humanos: uma noção em construção. In: TOSI, Giuseppe (Org.). Direitos humanos: história, teoria e prática. João Pessoa: Ed. Universitária, 2005. p. 50.

${ }^{407}$ SANTOS, Enoque Ribeiro dos. Direitos humanos na negociação coletiva: teoria e prática jurisprudencial. São Paulo: LTr, 2004. p. 29.

${ }^{408}$ LABRADA RUBIO, Valle. Introduccion a la teoria de los derechos humanos. Fundamento. Historia. Declaracion Universal de 10 de deciembre de 1948. Madrid: Civitas, 1998. p. 20. 
humanos", "direitos do homem", "direitos subjetivos públicos", "liberdades públicas", "direitos individuais", "liberdades fundamentais", "direitos humanos fundamentais", apenas para citar algumas daquelas mais importantes. ${ }^{409}$ Curiosamente, verifica-se o "uso promíscuo de tais denominações na literatura jurídica, ocorrendo porém o emprego mais freqüente de direitos humanos e direitos do homem entre autores anglo-americanos e latinos, em coerência aliás com a tradição e a história, enquanto a expressão direitos fundamentais parece ficar circunscrita à preferência dos publicistas alemães". ${ }^{410}$

Um exame precipitado destas denominações pode conduzir a uma confusão se essas expressões distintas forem tomadas para designar o mesmo objeto quando, na verdade, tratarem-se de múltiplas figuras. ${ }^{411}$

Segundo Pablo Lucas Verdú, a expressão “direitos do homem” procede do Liberalismo individualista do século XVIII, sob influência da ideologia da Ilustração combinada com o jusnaturalismo individualista; “direitos públicos subjetivos”, por sua vez, é uma denominação nascida no seio da doutrina germânica do final século XIX; o termo "direitos humanos" reflete a influência do jusnaturalismo crítico. ${ }^{412}$

O termo "direitos fundamentais", ou melhor, droit fondamentaux, surgiu na França por volta de 1770, como marco do desenvolvimento político e cultural que culminou com a Declaração dos Direitos do Homem e do Cidadão, de $1789 .{ }^{413}$ Esta denominação aparece na Constituição de Weimar de 1919 e em outras posteriores a 1945, como a Constituição Espanhola. ${ }^{414}$ Como a declaração francesa representa a primeira positivação dos direitos humanos no continente europeu, existe uma relação direta entre o uso da expressão “direitos fundamentais" e positivação ou reconhecimento destes direitos no ordenamento interno dos Estados. ${ }^{415}$

Os termos "direitos do homem", "direitos humanos" e "direitos da pessoa humana" podem ser considerados similares e, também, criticados por pecarem pela redundância, uma vez que a idéia de que os direitos são próprios e exclusivos da pessoa humana é

\footnotetext{
${ }^{409}$ SARLET, Ingo Wolfgang. A eficácia dos direitos fundamentais. 9. ed. Porto Alegre: Livr. do Advogado, 2007. p. 33.

${ }^{410}$ BONAVIDES, Paulo. Curso de direito constitucional. 12. ed. São Paulo: Malheiros Ed., 2002. p. 514.

${ }^{411}$ LUCAS VERDÚ, Pablo. Los derechos humanos como "religión civil". In: GRAU, Eros Roberto; GUERRA FILHO, Willis Santiago (Orgs.). Direito constitucional: estudos em homenagem a Paulo Bonavides. São Paulo: Malheiros Ed., 2003. p. 532.

${ }^{412}$ Id. Ibid., p. 532-533.

${ }^{413}$ PEREZ LUÑO, Antonio Enrique. Los derechos fundamentales. 7. ed. Madrid: Tecnos, 1998. p. 29.

${ }^{414}$ LUCAS VERDÚ, Pablo. op. cit., p. 533.

${ }^{415}$ LABRADA RUBIO, Valle. op. cit., p. 21.
} 
correntemente aceita. No entanto, o uso dessas fórmulas deve ser interpretado no sentido de que estes direitos assim designados são mais humanos que outros, porque se refere ao homem em virtude da sua condição humana. ${ }^{416}$

As denominações "direitos naturais", "direitos inatos" e "direitos originários" são similares, sendo que a primeira delas tem sido mais utilizada que as demais ao longo da história do pensamento jurídico. E substituída pelas expressões apresentadas no parágrafo anterior. $^{417}$

As expressões "liberdades fundamentais" ou "liberdades públicas" têm um caráter mais político. São relativos aos direitos políticos, isto é, referem-se a uma classe dos direitos humanos, por isso, são mais restritivas.

O texto constitucional brasileiro faz uso de uma diversidade de termos para referirse aos direitos fundamentais. São empregadas diversas expressões, como por exemplo: "direitos humanos", no inciso II do artigo $4^{\text {o; }}$ "direitos e garantias fundamentais", na epígrafe do Título II e $\S 1^{\circ}$ do artigo $5^{\circ}$; “direitos e liberdades constitucionais”, na letra $d$ do inciso LXXI do artigo $5^{\circ}$; 'direitos e garantias individuais", no inciso IV, $\S 4^{\circ}$ do artigo $60 .^{418}$

As expressões "direitos humanos" e "direitos fundamentais", muitas vezes, são utilizadas indistintamente ${ }^{419}$, no entanto, são muitas as tentativas doutrinárias no sentido de explicar o verdadeiro alcance de cada uma delas. Costuma-se reservar ao termo "direitos fundamentais" o sentido de direitos positivados a nível interno e a "direitos humanos" seria mais usual para denominar os direitos naturais positivados nas declarações e convenções internacionais, assim como, aquelas relacionadas com a dignidade, a liberdade e a igualdade das pessoas que não estão protegidas por um estatuto jurídico positivo. ${ }^{420}$

Outra idéia menos convincente defendida pela doutrina sustenta que, enquanto os direitos fundamentais são garantidos constitucionalmente aos cidadãos, isto é, às pessoas pertencentes a um determinado Estado, os direitos humanos são aqueles formulados positivamente nos textos constitucionais a todas as pessoas, independentemente de serem nacionais daquele Estado. Este último posicionamento é equivocado, pois promove uma

\footnotetext{
${ }^{416}$ LABRADA RUBIO, Valle. op. cit., p. 19.

${ }^{417}$ Id. Ibid., p. 20.

${ }^{418}$ SARLET, Ingo Wolfgang. op. cit., p. 33-34.

${ }^{419}$ LABRADA RUBIO, Valle. op. cit., p. 20.

${ }^{420}$ PEREZ LUÑO, Antonio Enrique. op. cit., p. 44.
} 
confusão entre os direitos fundamentais e os direitos civis e políticos e os direitos humanos com os direitos pessoais. ${ }^{421}$

Peres Luño considera mais adequado tomar como critério distintivo o grau de concretização positiva das duas categorias, sendo que na acepção jurídica ou política, como também, no uso comum o termo, "direitos humanos" surge com contornos mais amplos e imprecisos que a noção presente em "direitos fundamentais". O autor a seguir complementa afirmando que "os direitos humanos costumam vir entendidos como um conjunto de faculdades e instituições que em cada momento histórico, concretizam as exigências da dignidade, da liberdade e da igualdade humanas, as quais devem ser reconhecidas positivamente pelos ordenamentos jurídicos a nível nacional e internacional. Enquanto isso, com a noção de direitos fundamentais tende a referir-se àqueles direitos humanos garantidos pelo ordenamento jurídico positivo, na maior parte dos casos em sua normativa constitucional, e que costumam gozar de uma tutela reforçada". ${ }^{422}$.

Ingo Wolfgang Sarlet apresenta como distinção corriqueira e procedente aquela cujo “termo 'direitos fundamentais' se aplica para aqueles direitos do ser humano reconhecidos e positivados na esfera do direito constitucional positivo de determinado Estado, ao passo que a expressão 'direitos humanos' guardaria relação com os documentos de direito internacional, por referir-se àquelas posições jurídicas que se reconhecem ao ser humano como tal, independentemente de sua vinculação com determinada ordem constitucional, e que, portanto, aspiram à validade universal, para todos os povos e tempos, de tal sorte que revelam um inequívoco caráter supranacional". 423

$\mathrm{O}$ autor mencionado anteriormente ainda adverte que "reconhecer a diferença, contudo, não significa desconsiderar a íntima relação entre os direitos humanos e os direitos fundamentais, uma vez que a maior parte das Constituições do segundo pós-guerra se inspirou tanto na Declaração Universal de 1948, quanto nos diversos documentos internacionais e regionais que as sucederam, de tal sorte que - no que diz com o conteúdo das declarações internacionais e dos textos constitucionais - está ocorrendo um processo de aproximação e harmonização, rumo ao que já está sendo denominado (e não

\footnotetext{
${ }^{421}$ PEREZ LUÑO, Antonio Enrique. op. cit., p. 44.

${ }^{422}$ Id. Ibid.

${ }^{423}$ SARLET, Ingo Wolfgang. op. cit., p. 35-36.
} 
exclusivamente - embora principalmente -, no campo dos direitos humanos e fundamentais) de um direito constitucional internacional". ${ }^{424}$

O direito constitucional internacional é entendido como o ramo do direito no qual se verifica a fusão e a interação entre o direito constitucional e o direito internacional, principalmente, ressaltando-se que o elemento primordial de interseção entre esses dois ramos do direito é a proteção de um mesmo valor, ou seja, o valor da primazia da pessoa humana. Este fato é verificável, sobretudo, na fase de constitucionalização dos direitos humanos observada no século XIX, quando os Estados passaram a acolher nos seus textos constitucionais os direitos constantes nas declarações internacionais de direitos humanos, levando a incorporação delas na própria história do constitucionalismo. ${ }^{425}$

Mais recentemente, observa-se o uso da expressão direitos humanos fundamentais entre alguns autores, como é o caso de Manoel Gonçalves Ferreira Silva, que considera que o termo "direitos fundamentais" figura como uma abreviação de "direitos humanos fundamentais", ${ }^{426}$ e Alexandre de Moraes, que usa a terminologia "direitos humanos e fundamentais" ao concluir que tais direitos têm por finalidade "consagrar o respeito à dignidade humana, garantir a limitação de poder e visar ao pleno desenvolvimento da personalidade humana". ${ }^{427}$

Sérgio Resende de Barros refuta a tese que defende a existência de uma distinção entre os direitos humanos e os direitos fundamentais, porém considera que o uso da expressão direitos humanos fundamentais tem como vantagem ressaltar a unidade essencial e indissolúvel entre direitos humanos e direitos fundamentais. ${ }^{428}$

A posição do autor, exposta anteriormente, não apresenta uma incongruência absoluta com a posição que defende a distinção entre as duas figuras, pois, apesar de observar uma diferenciação no plano da positivação dos direitos, não deixa de reconhecer uma conexão íntima entre os direitos humanos e os direitos fundamentais que é o reconhecimento e a proteção de valores essenciais a todos os seres humanos. ${ }^{429}$

\footnotetext{
${ }^{424}$ SARLET, Ingo Wolfgang. op. cit., p. 39.

${ }^{425}$ PIOVESAN, Flávia. Direitos humanos e o direito constitucional internacional. 4. ed. São Paulo: Max Limonad, 2000. p. 42-43.

${ }^{426}$ FERREIRA FILHO, Manoel Gonçalves. Direitos humanos fundamentais. 4. ed. São Paulo: Saraiva, 2000. p. 14.

${ }^{427}$ MORAES, Alexandre de. Direitos humanos fundamentais: teoria geral, comentários aos arts. $1^{\circ}$ a $5^{\circ}$ da Constituição da República Federativa do Brasil, doutrina e jurisprudência. 7. ed. São Paulo: Atlas, 2006. p. 2.

${ }^{428}$ BARROS, Sergio Resende de. Direitos humanos: paradoxo da civilização, 2001 Tese (Livre docência) Faculdade de Direito, Universidade de São Paulo, São Paulo, 2001. p. 29 e ss.

${ }^{429}$ SARLET, Ingo Wolfgang. op. cit., p. 39-40.
} 
No presente estudo optamos pela expressão direitos humanos fundamentais, pois o tema em analise, o direito de greve dos servidores públicos, constitui um direito tanto resguardado nos documentos internacionais de direitos humanos como é um direito fundamental garantido nos textos constitucionais pertencentes a ordenamentos jurídicos de muitos Estados, como já foi verificado, e, em particular, no caso do Brasil. Também, em razão de defendermos que este é um direito essencial do homem trabalhador, independentemente da sua vinculação a um empregador do setor privado ou ao Estado.

\subsection{Conceito}

Ao indagarmos a várias pessoas sobre o que elas entendem sobre direitos humanos, certamente obteremos uma gama bastante variada de respostas, inclusive aquela que critica a pergunta por considerá-la supérflua com base na justificativa de que é óbvio que indagação é auto-explicativa. ${ }^{430}$

Assim, como ocorre com as denominações, existem diferentes conceitos de direitos humanos e entre os mais dispares e representativos podem ser destacados aqueles que representam uma postura positivista ou legalista e aqueles que descrevem uma postura jusnaturalista. Para estes os direitos humanos, como é da predileção deste grupo denominar, não têm origem na lei positiva, mas na natureza do homem, em sua razão, ou outra realidade superior à lei positiva humana. Em contrapartida, para aqueles, os direitos fundamentais, como preferem denominar, são os direitos reconhecidos como tal pelo ordenamento jurídico. ${ }^{431}$

Chaïm Perelman destaca que "a noção de direitos humanos implica que se trata de direitos atribuíveis a cada ser humano enquanto tal, que esses direitos são vinculados à qualidade de ser humano, não fazendo distinção entre eles e não se estendendo a mais além. Reconheça-se ou não a origem religiosa do lugar especial reservado aos seres humanos nessa doutrina, proclama ela que a pessoa possui dignidade que lhe é própria e

\footnotetext{
${ }^{430}$ PEREZ LUÑO, Antonio Enrique. Derechos humanos, estado de derecho y constitucion. 8. ed. Madrid: Tecnos, 2003. p. 22.

${ }^{431}$ LABRADA RUBIO, Valle. op. cit., p. 21.
} 
merece respeito enquanto sujeito moral livre, autônomo e responsável. Daí a situação ímpar que lhe é reconhecida e que o direito tem de proteger". 432

Enoque Ribeiro dos Santos lembra que "o conceito da expressão direitos humanos pode ser atribuído aos valores ou direitos inatos e imanentes à pessoa humana, pelo simples fato de ter ela nascido com esta qualificação jurídica. São direitos que pertencem à essência ou à natureza intrínseca da pessoa humana, que não são acidentais e suscetíveis de aparecerem e desaparecerem em determinadas circunstâncias. São direitos eternos, inalienáveis, imprescritíveis que se agregam à natureza da pessoa humana, pelo simples fato de ela existir no mundo do direito". 433

Bobbio nos adverte que a expressão "direitos do homem" é bastante vaga e que a maioria das definições são tautológicas, resultando inúteis como a descrita em "os direitos do homem são os que cabem ao homem" ou representam mais uma expectativa que um conteúdo como em "direitos do homem são aqueles que pertencem, ou deveriam pertencer, a todos os homens, ou dos quais nenhum homem pode ser despojado" ou, ainda, exprimem algum conteúdo, porém com o uso de termos avaliativos como em "direitos do homem são aqueles cujo reconhecimento é condição necessária para o aperfeiçoamento da pessoa humana, ou para o desenvolvimento da civilização". 434

Perez Luño assevera que podemos distinguir três tipos de definição de direitos humanos: as tautológicas, as formais e as teleológicas. O primeiro tipo não apresenta nenhum elemento que permita caracterizar tais direitos, como aquele que afirma que "os direitos humanos são os que correspondem aos homens em função da sua condição humana”. O segundo, não explica o conteúdo destes direitos, limitando-se a alguma indicação sobre o estatuto desejado ou proposto. Como exemplo, temos: "os direitos humanos são aqueles que pertencem ou que devem pertencer a todos os homens e dos quais nenhum homem pode ser privado". E, finalmente, o terceiro tipo faz uso dos fins ou objetivos para definir o conjunto de direitos humanos. Pode ser exemplificado por: "os direitos humanos são aqueles imprescindíveis para o aperfeiçoamento da pessoa humana, para o progresso social, ou para o desenvolvimento da civilização". ${ }^{435}$

\footnotetext{
${ }^{432}$ PERELMAN, Chaïn. Ética e direito. Trad. Maria Ermantina Galvão. São Paulo: Martins Fontes, 1996. p. 400.

${ }^{433}$ SANTOS, Enoque Ribeiro dos. Direitos humanos na negociação coletiva: teoria e prática jurisprudencial, cit., p. 38.

${ }^{434}$ BOBBIO, Norberto. A era dos direitos. Tradução de Carlos Nelson Coutinho. Rio de Janeiro: Campus, 1992. p. 17.

${ }^{435}$ PEREZ LUÑO, Antonio Enrique. Derechos humanos, estado de derecho y constitucion, cit., p. 25.
} 
Neste sentido, Paulo Bonavides com base em Konrad Hesse, apresenta um conceito lato de direitos fundamentais e outro numa acepção restrita, específica e normativa. Enquanto o primeiro deles diz respeito àqueles direitos que visam criar e manter os pressupostos elementares de uma vida na liberdade e na dignidade humana, o segundo faz referência aos direitos que o direito vigente qualifica como tais. ${ }^{436}$

Carl Schmitt, como lembra Paulo Bonavides, afirma que direitos fundamentais sob o ponto de vista de critérios formais de caracterização são todos os direitos e garantias nomeados e especificados no instrumento constitucional. E ainda, caracteriza os direitos fundamentais como aqueles direitos que receberam da Constituição um grau mais elevado de garantia ou segurança, como a imutabilidade ou alteração dificultada. Materialmente, no entanto, os direitos fundamentais, segundo Schmitt, podem variar conforme a ideologia, a modalidade de Estado, a espécie de valores e princípios consagrados na Constituição, ou seja, cada Estado tem os seus próprios direitos fundamentais. ${ }^{437}$

Há quem defenda ainda que "o catálogo dos direitos fundamentais vem-se avolumando, conforme as exigências específicas de cada momento histórico. A classe dos direitos que são considerados fundamentais não tende à homogeneidade, o que dificulta uma conceituação material ampla e vantajosa que alcance todos eles. Tampouco a própria estrutura normativa dos diversos direitos fundamentais não é coincidente em todos os casos". 438

Ingo Wolfgang Sarlet afirma que "o princípio da dignidade da pessoa humana vem sendo considerado fundamento de todo o sistema de direitos fundamentais, no sentido de que estes constituem exigências, concretizações e desdobramentos da dignidade da pessoa humana e que com base nesta devem ser interpretados". 439

É importante ressaltar que o autor aponta a íntima relação entre o valor da dignidade humana e a "garantia de condições justas e adequadas de vida para o indivíduo e sua família, contexto no qual assumem relevo do modo especial os direitos sociais ao trabalho, a um sistema efetivo de seguridade social, em última análise, à proteção da

\footnotetext{
${ }^{436}$ Konrad Hesse. Apud BONAVIDES, Paulo op. cit., p. 514.

${ }^{437}$ Carl Schmitt. Apud Id. Ibid., p. 515.

${ }^{438}$ MENDES, Gilmar Ferreira; COELHO, Inocêncio Mártires; BRANCO, Paulo Augusto Gonet. Curso de direito constitucional. São Paulo: Saraiva, 2007.

${ }^{439}$ SARLET, Ingo Wolfgang. op. cit., p. 123.
} 
pessoa contra as necessidades de ordem material e à asseguração de uma existência com dignidade". 440

Alexandre de Moraes afirma que "o conjunto institucionalizado de direitos e garantias do ser humano que tem por finalidade básica o respeito a sua dignidade, por meio de sua proteção contra o arbítrio do poder estatal, e o estabelecimento de condições mínimas de vida e desenvolvimento da personalidade humana pode ser definido como direitos humanos fundamentais", 441

Uma definição notável em razão da compatibilidade alcançada entre a evolução histórica desses direitos e o seu conteúdo é a apresentada por Perez Luño, na qual "os direitos humanos aparecem como um conjunto de faculdades e instituições que, em cada momento histórico, concretizam as exigências de dignidade, de liberdade e de igualdade humanas, as quais devem ser reconhecidas positivamente pelos ordenamentos jurídicos em nível nacional e internacional". ${ }^{442}$

\subsection{Características}

A Declaração francesa de 1789 foi a mais abstrata das formulações solenes sobre a liberdade e de abrangência geral, uma vez que tinha por destinatário o gênero humano, sendo que "os direitos do homem ou da liberdade, se assim podemos exprimi-los, eram ali 'direitos naturais, inalienáveis e sagrados', direitos tidos também por imprescritíveis, abraçando a liberdade, a propriedade, a segurança e a resistência à opressão". 443 Eis algumas das características recorrentes quando tratamos dos direitos humanos. No entanto, apresentá-las de forma que sejam sempre válidas e aceitas independentemente do lugar é uma tarefa bastante complexa e talvez impossível, assim como ocorre com o trabalho de conceituar esses direitos. $^{444}$ Os autores, geralmente, apresentam suas listas de características, algumas delas coincidentes, outras, no entanto, inovadoras como veremos a seguir.

\footnotetext{
${ }^{440}$ SARLET, Ingo Wolfgang. op. cit., p. 117.

${ }^{441}$ MORAES, Alexandre de. op. cit., p. 21.

${ }^{442}$ PEREZ LUÑO, Antonio Enrique. Derechos humanos, estado de derecho y constitucion, cit., p. 48.

${ }^{443}$ BONAVIDES, Paulo op. cit., p. 516.

${ }^{444}$ MENDES, Gilmar Ferreira; COELHO, Inocêncio Mártires; BRANCO, Paulo Augusto Gonet. op. cit., p. 229.
} 
Alexandre de Moraes sustenta que os direitos fundamentais são dotados de características variadas, entre as quais estão a imprescritibilidade, a inalienabilidade, a irrenunciabilidade, a inviolabilidade, a universalidade, a efetividade, a interdependência e a complementaridade. ${ }^{445}$ Mas estas não são as únicas características apontadas pela doutrina.

Freqüentemente, algumas características são associadas aos direitos fundamentais, entre as quais podemos destacar que: (i) eles são direitos universais, na medida em que todas as pessoas são titulares desses direitos, e absolutos, no sentido de se situarem no patamar máximo da hierarquia jurídica e de não tolerarem restrição, embora haja controvérsias; (ii) eles são direitos dotados de historicidade, pois são resultado de uma evolução determinada pelo contexto histórico; de inalienabilidade e indisponibilidade, porque não admitem que seu titular os tornem impossíveis de serem exercitados para si mesmo, física ou juridicamente; (iii) os direitos fundamentais são direitos submetidos à constitucionalização, uma vez que geralmente esses direitos são acolhidos no texto constitucional, isso para aqueles que fazem distinção entre direitos humanos e direitos fundamentais; (iv) são direitos submetidos à vinculação dos poderes públicos (Legislativo, Executivo e Judiciário), pelo fato de estarem previstos na Constituição torna-os parâmetros de organização e de limitação dos poderes constituídos; (v) são direitos com aplicabilidade imediata, pois são normas de caráter preceptivo e não simplesmente programático. ${ }^{446}$

André de Carvalho Ramos, por sua vez, defende que as características dos direitos humanos na ordem internacional são a superioridade normativa, a universalidade, a indivisibilidade, a interdependência, a indisponibilidade, o caráter erga omnes, a exigibilidade, a abertura, a aplicabilidade imediata, a dimensão objetiva, a proibição do retrocesso e a eficácia horizontal. ${ }^{447}$

A superioridade normativa pode ser identificada, no caso do direito interno, pela hierarquia superior das normas de direitos humanos em relação às demais normas do ordenamento jurídico, pois, geralmente, aquelas são normas de estatura constitucional. No tocante ao direito internacional, a idéia da hierarquia das normas ainda é incipiente e de desenvolvimento recente, apesar de haver uma discussão sobre a existência de normas imperativas ou cogentes, assim consideradas por conterem valores fundamentais da

\footnotetext{
${ }^{445}$ MORAES, Alexandre de. op. cit., p. 23.

${ }^{446}$ MENDES, Gilmar Ferreira; COELHO, Inocêncio Mártires; BRANCO, Paulo Augusto Gonet. op. cit., p. 229-243.

${ }^{447}$ RAMOS, André de Carvalho. Teoria geral dos direitos humanos na ordem internacional. Rio de Janeiro: Renovar, 2005. p. 161 e ss.
} 
sociedade internacional, podendo ser derrogadas apenas por normas de igual dignidade. ${ }^{448}$ Sendo assim, "os direitos humanos, conforme as normas internacionais costumeiras e convencionais, constituem-se no núcleo essencial de normas que compõe o ordenamento jurídico internacional contemporâneo (...) quer pelo critério material (conteúdo) ou quer pelo critério formal (norma de jus cogens) a norma de direitos humanos é norma hierarquicamente superior no ordenamento jurídico internacional", ${ }^{4} 9$

A universalidade dos direitos humanos é evidenciada pela abrangência desses direitos em relação a todos os indivíduos, independentemente de sua nacionalidade, sexo, raça, credo ou convicção político-filosófica. ${ }^{450}$ Essa característica engloba três planos tradicionais: o da titularidade, o temporal e o cultural, sendo que esses dois últimos são decorrência do primeiro. Este plano aponta que os direitos humanos são universais porque são seus titulares todos os seres humanos sem distinção de qualquer natureza. De acordo com o segundo plano, a universalidade é marcada pelo fato dos homens serem detentores desses direitos independentemente da época histórica a que pertencerem. Finalmente, o terceiro e último plano demonstra a universalidade dos direitos humanos por estes permearem todas as culturas em qualquer parte do globo. ${ }^{451}$

A universalidade foi reconhecida na II Conferência Mundial de Direitos Humanos, realizada em Viena, em 1993 que teve como resultado uma Declaração e um Programa de Ação. Ficou estabelecido que:

"Seção I, item 5: Todos os direitos humanos são universais, indivisíveis interdependentes e inter-relacionados. A comunidade internacional deve tratar os direitos humanos de forma global, justa e eqüitativa, em pé de igualdade e com a mesma ênfase. Embora particularidades nacionais e regionais devam ser levadas em consideração, assim como diversos contextos históricos, culturais e religiosos, é dever dos Estados promover e proteger todos os direitos humanos e liberdades fundamentais, sejam quais forem seus sistemas politicos, econômicos e culturais "452

Paulo Bonavides assevera que "a vinculação essencial dos direitos fundamentais à liberdade e à dignidade humana, enquanto valores históricos, nos conduzirá sem óbices ao significado de universalidade inerente a esses direitos como ideal da pessoa humana. A

\footnotetext{
${ }^{448}$ RAMOS, André de Carvalho. op. cit., 165-166.

${ }^{449}$ Id. Ibid., p. 176-177.

${ }^{450}$ MORAES, Alexandre de. op. cit., p. 23.

${ }^{451}$ RAMOS, André de Carvalho. op. cit., p. 179. PECES-BARBA, Gregório et al. Curso de derechos fundamentales: teoria general. Madrid: Universidad Carlos II e Boletín Oficial del Estado, 1999. p. 299.

${ }^{452}$ DECLARAÇÃ̃O E PROGRAMA DE AÇÃO DE VIENA. Disponível em: http://www.dhnet.org.br/direitos/anthist/viena/declaracao_viena.htm>. Acesso em: 12 jan. 2009.
} 
universalidade se manifestou pela vez primeira, qual descoberta do racionalismo francês da Revolução, por desejo da célebre Declaração dos Direitos do Homem de 1789."453

Bobbio observa que "somente depois da Declaração Universal é que podemos ter a certeza histórica de que a humanidade - partilha alguns valores comuns; e podemos, finalmente, crer na universalidade dos valores, no único sentido em que tal crença é historicamente legítima, ou seja, no sentido em que universal significa não algo dado objetivamente, mas algo subjetivamente acolhido pelo universo dos homens. Esse universalismo foi uma lenta conquista." ${ }^{454}$

A indivisibilidade dos direitos humanos foi reconhecida no plano internacional na I Conferência Mundial de Direitos Humanos em 1968, em Teerã, e é resultado do entendimento acerca da constatação de que todos os direitos humanos devem ter a mesma proteção jurídica, tendo em vista que são essenciais para uma vida digna.

Segundo a Proclamação de Teerã, de 13 de maio de 1968, aprovada pela I Conferência de Direitos Humanos:

"13. Como os direitos humanos e as liberdades fundamentais são indivisiveis, a realização dos direitos civis e políticos sem o gozo dos direitos econômicos, sociais e culturais resulta impossível. A realização de um progresso duradouro na aplicação dos direitos humanos depende de boas e eficientes políticas internacionais de desenvolvimento econômico e social". ${ }^{455}$

É possível identificar duas facetas na indivisibilidade, isto é, primeiro o reconhecimento de que o direito protegido apresenta uma unidade incindível em si e, segundo, o fato de que não é possível proteger apenas alguns dos direitos humanos reconhecidos. ${ }^{456}$

A interdependência dos direitos humanos consiste na "mútua dependência entre os direitos humanos protegidos, pois o conteúdo de um pode vir a se vincular ao conteúdo do outro, demonstrando interação e complementaridade entre eles, bem como que certos direitos são desdobramentos de outros. Como por exemplo, há clara complementaridade a liberdade de associação e o reconhecimento do direito de associação profissional ou

\footnotetext{
${ }^{453}$ BONAVIDES, Paulo op. cit., p. 516.

${ }^{454}$ BOBBIO, Norberto. A era dos direitos, cit., p. 28.

${ }^{455}$ PROCLAMAÇÃO DE TEERÃ. Disponível em: <http://www.dhnet.org.br/direitos/sip/onu/doc/teera.htm>. Acesso em: 12 jan. 2009.

${ }^{456}$ RAMOS, André de Carvalho. op. cit., p. 199-200.
} 
sindical", ${ }^{457}$ por sua vez, também são complementares a liberdade sindical e o direito de greve. As muitas previsões de direitos humanos, "apesar de autônomas, possuem diversas intersecções para atingirem suas finalidades. Assim, por exemplo, a liberdade de locomoção está intimamente ligada à garantia do habeas corpus", também, estaria incompleta a liberdade sindical sem a garantia do pleno exercício do direito de greve. ${ }^{458}$

Os direitos humanos são indisponíveis na medida em que é reconhecida a sua total irrenunciabilidade ou que a vontade de seu titular no sentido de renúncia ou disposição, apenas pode ser manifestada sob controle. Essa limitação da liberdade do titular de um direito de proceder a sua renúncia era inicialmente justificada com base na violação da ordem pública, da moral e dos bons costumes. No entanto, atualmente, com a consagração da dignidade da pessoa humana como valor supremo, tanto no direito interno como no direito internacional, essa justificativa foi superada. Os limites impostos à autonomia da vontade, em face da proteção dos direitos humanos, são balizados em razão da dignidade da pessoa humana e das desigualdades matérias dos indivíduos. ${ }^{459}$

O caráter erga omnes dos direitos humanos é evidenciado em duas situações: (i) no reconhecimento do interesse de todos os Estados da comunidade internacional de verem respeitados os direitos protegidos pelo direito internacional e (ii) na aplicação geral das normas protetivas a todos os seres humanos sob a jurisdição de um Estado, independentemente de nacionalidade ou de qualquer outra forma de distinção. ${ }^{460}$

A exigibilidade dos direitos humanos ganha cada vez mais destaque na atualidade, pois como nos alerta Norberto Bobbio, "o problema fundamental em relação aos direitos do homem, hoje, não é tanto justificá-los, mas protegê-los". ${ }^{461}$ Isso impulsiona um novo foco da proteção internacional dos direitos humanos quanto à análise da responsabilidade internacional do Estado para combater as violações a suas normas e a busca de reparação aos danos causados. ${ }^{462}$

Os direitos humanos são marcados pela existência de uma cláusula aberta ou de um princípio de não-tipicidade, em razão dos direitos serem protegidos pelo seu conteúdo, o valor da dignidade da pessoa humana, e não pela presença deles num rol de um instrumento constitucional ou internacional. Isso explica a existência de margens móveis

\footnotetext{
${ }^{457}$ RAMOS, André de Carvalho. op. cit., p. 203.

${ }^{458}$ MORAES, Alexandre de. op. cit., p. 23.

${ }^{459}$ RAMOS, André de Carvalho. op. cit., p. 207-209.

${ }^{460}$ Id. Ibid., p. 2213-214.

${ }^{461}$ BOBBIO, Norberto. A era dos direitos, cit., p. 23.

${ }^{462}$ RAMOS, André de Carvalho. op. cit., p. 215-216.
} 
para o conjunto de direitos humanos assegurados pela sociedade marcada pelo contexto histórico. Além disso, "esse filtro axiológico, que é a fundamentalidade material, existe mesmo com a positivação constitucional e internacional dos chamados direitos humanos, sendo também denominado eficácia irradiante dos direitos fundamentais. Assim, os direitos humanos são dotados de uma carga expansiva, devendo a sua interpretação ser ampliativa, de modo a favorecer o indivíduo". 463

A fundamentalidade material está presente na Constituição brasileira de 1988, pois o seu parágrafo $2^{\circ}$ do artigo $5^{\circ}$ faz remissão a outros direitos fundamentais que não constam do texto constitucional, evidenciando a abertura desses direitos. Na mesma linha, o artigo 29, $c$ da Convenção Americana de Direitos Humanos estabelece que não é possível interpretação que venha a excluir outros direitos e garantias que são inerente ao ser humano. $^{464}$

O catálogo de direitos humanos tende ser ampliado de forma que "não é difícil prever que, no futuro, poderão emergir novas pretensões que no momento nem sequer podemos imaginar" ${ }^{465}$, resultando no reconhecimento de novos direitos fundamentais.

Com o objetivo de promover a defesa dos direitos humanos é adotada a aplicabilidade imediata dos textos normativos às situações de fato que se apresentam, podendo ser invocados desde logo. ${ }^{466}$ A Constituição brasileira de 1988 estabelece no artigo $5^{\circ}$, parágrafo primeiro que as normas relativas aos direitos fundamentais têm aplicação imediata.

No plano internacional estabeleceu-se a chamada proibição do retrocesso, segundo a qual é vedado aos Estados diminuírem ou amesquinharem a proteção já conferida aos direitos humanos, de forma que mesmo novos tratados internacionais não poderão impor restrições ou diminuir o amparo já alcançado. ${ }^{467}$

Finalmente, eficácia horizontal dos direitos humanos é a característica também denominada eficácia externa ou eficácia em relação a terceiros ou, ainda, eficácia dos direitos fundamentais na ordem jurídica privada. Ela consiste na aplicação, sem a mediação de lei, dos direitos fundamentais nas relações entre particulares. Muito embora não seja unânime esse posicionamento, há quem defenda que os direitos fundamentais aplicam-se

\footnotetext{
${ }^{463}$ RAMOS, André de Carvalho. op. cit., p. 221-222.

${ }^{464}$ RANGEL, Vicente Marotta. op. cit., p. 715-716.

${ }^{465}$ BOBBIO, Norberto. A era dos direitos, cit., p. 18.

${ }^{466}$ RAMOS, André de Carvalho. op. cit., p. 225.

${ }^{467}$ Id. Ibid., p. 243-244.
} 
“obrigatoriamente e diretamente na realização dos atos jurídicos entre pessoas e entes privados (...) podendo cada indivíduo, sem qualquer necessidade de mediação concretizadora de atos normativos ou leis, invocar os direitos e garantias individuais nas suas relações privadas". 468

Ainda, entre as características arroladas por André de Carvalho Ramos está a dimensão objetiva que "implica em reconhecer que os direitos humanos não devem ser entendidos apenas como um conjunto de posições jurídicas conferidas a seus titulares, mas também como um conjunto de regras impositivas de comportamentos voltadas à proteção e satisfação daqueles direitos conferidos aos indivíduos. De fato, essa dimensão objetiva faz com que direitos humanos sejam regras de imposição de deveres, em geral ao Estado, de implementação e desenvolvimento dos direitos individuais". ${ }^{469}$

Como veremos a seguir, a concepção contemporânea de direitos humanos é fruto da internacionalização dos direitos humanos, surgida no pós-guerra como resposta aos crimes cometidos durante o nazismo. Com o fim da Segunda Guerra Mundial busca-se a reconstrução dos direitos humanos, sendo a Declaração Universal dos Direitos Humanos, de 1948, o marco dessa reconstrução. Ela introduz a concepção contemporânea de direitos humanos que se caracteriza pela universalidade e pela individualidade: "Universalidade porque clama pela extensão universal dos direitos humanos, sob a crença de que a condição de pessoa é o requisito único para a titularidade de direitos, considerando o ser humano como um ser essencialmente moral, dotado de unicidade existencial e dignidade. Indivisibilidade porque a garantia dos direitos civis e políticos é condição para a observância dos direitos sociais, econômicos e culturais e vice-versa. Quando um deles é violado, os demais também o são. Os direitos humanos compõem, assim, uma unidade indivisível, interdependente e inter-relacionada, capaz de conjugar o catálogo de direitos civis e culturais. Consagra-se, deste modo, a visão integral dos direitos humanos." 470

Mais que identificar, as características arroladas pela doutrina e pelas normas de direito interno e de direito internacional visam proteger e promover os direitos humanos, pois esclarecem o verdadeiro sentido deles e direcionam a sua interpretação para garantir a sua máxima eficiência. ${ }^{471}$

\footnotetext{
${ }^{468}$ RAMOS, André de Carvalho. op. cit., p. 247-248.

${ }^{469}$ Id. Ibid., p. 237.

${ }^{470}$ PIOVESAN, Flávia. Direitos humanos e o trabalho. In: FREITAS JÚNIOR, Antonio Rodrigues de (Org.). Direito do trabalho: direitos humanos. Leme, SP: Ed. BH, 2006. p. 290.

${ }^{471}$ FIORAVANTE, Tamira Maira. Sindicato, educação e liberdade. São Paulo: LTr, 2008. p. 16.
} 


\subsection{Evolução dos direitos humanos}

Os direitos humanos são resultado, não da descoberta de um elemento novo, mas fruto de uma longa tarefa de criação da humanidade ao reconhecer direitos inerentes à condição humana, num processo constante de construção e reconstrução. ${ }^{472}$ Ao longo da história da humanidade, ocorreu "a revelação de que todos os seres humanos, apesar das inúmeras diferenças biológicas e culturais que os distinguem entre si, merecem igual respeito, como únicos entes no mundo capazes de amar, descobrir a verdade e criar a beleza. É o reconhecimento de que, em razão dessa radical igualdade, ninguém - nenhum indivíduo, gênero, etnia, classe social, grupo religioso ou nação - pode afirmar-se superior aos demais". 473

Não temos a pretensão de esgotarmos o tema referente à evolução histórica dos direitos humanos. Essa opção é feita não em virtude da falta de interesse pelo tema, uma vez que o assunto é fascinante, mas em decorrência da falta de espaço neste trabalho para uma análise mais profunda. Passaremos, então, a fazer referência apenas há alguns aspectos relevantes com o intuito de situarmos a questão espacial e temporalmente e de garantirmos uma adequada compreensão da importância e da função dos direitos humanos.

Os direitos humanos, "nascem como direitos naturais universais, desenvolvem-se como direitos positivos particulares, para finalmente encontrarem sua plena realização como direitos positivos universais". 474

K. Stern ressalta que a evolução dos direitos humanos pode ser divida em três etapas: (i) a fase pré-histórica, que se estende dos primórdios até o século XVI; (ii) a fase intermediária, identificada com o período de elaboração da doutrina jusnaturalista e da afirmação dos direitos naturais do homem; (iii) a fase de constitucionalização, iniciada em 1776, com as seguidas declarações de direitos dos novos Estados na América. ${ }^{475}$

\footnotetext{
${ }^{472}$ PIOVESAN, Flávia. op. cit., p. 122.

${ }^{473}$ COMPARATO, Fábio Konder. A afirmação histórica dos direitos humanos. 2. ed. São Paulo: Saraiva, 2001. p. 1.

${ }^{474}$ BOBBIO, Norberto. A era dos direitos, cit., p. 30.

${ }^{475}$ Apud SARLET, Ingo Wolfgang. op. cit., p. 43.
} 


\subsubsection{Primórdios}

Neste sentido, embora seja um consenso a idéia de que os primeiros direitos naturais não surgiram na antiguidade, é evidente que o mundo antigo ofereceu, por meio da religião e da filosofia, um legado que influenciou diretamente o pensamento jusnaturalista. Evidentemente, a concepção de ser humano construída, segundo esse modelo, torna corrente a idéia de que o homem, em razão do simples fato de existir, passa a ser titular de alguns direitos naturais e inalienáveis. Por isso, este período é tratado como pré-história dos direitos humanos. ${ }^{476}$

No campo da religião, a idéia da preeminência do homem no mundo tem origem com a afirmação da fé monoteísta. A crença na criação do mundo por um Deus único e transcendente difere bastante daquela professada pelos antigos, repleta de deuses que estavam sujeitos às mesmas paixões e defeitos humanos. A Bíblia apresenta uma contribuição substancial para a construção da dignidade humana, pois nela o homem ocupa uma posição superior na ordem da criação dos seres viventes, ${ }^{477}$ pois "do Antigo Testamento, herdamos a idéia de que o ser humano representa o ponto culminante da criação divina, tendo sido feito à imagem e semelhança de Deus" ${ }^{478}$.

A filosofia e a literatura grega apresentam outra justificativa para a preeminência da posição do homem no mundo. A indagação da filosofia grega acerca da natureza humana já apontava para a sua singularidade, como ser capaz de tornar-se objeto da sua própria reflexão. A racionalidade é considerada um atributo exclusivo do homem em função dessa capacidade reflexiva. ${ }^{479}$

Na antigüidade surge "a convicção de que todos os seres humanos têm direito a ser igualmente respeitados pelo simples fato de sua humanidade, nasce vinculado a uma instituição social de capital importância: a lei escrita, como regra geral e uniforme, igualmente aplicável a todos os indivíduos que vivem numa sociedade organizada". 480 Além disso, entre os gregos, ao lado da lei escrita, havia a lei não escrita, que encerra ambigüidade de significado, pois pode designar o costume juridicamente relevante ou leis

\footnotetext{
${ }^{476}$ SARLET, Ingo Wolfgang. op. cit., p. 44.

${ }^{477}$ COMPARATO, Fábio Konder. op. cit., p. 1-2.

${ }^{478}$ SARLET, Ingo Wolfgang. op. cit., p. 44.

${ }^{479}$ COMPARATO, Fábio Konder. op. cit., p. 3.

${ }^{480}$ Id. Ibid., p. 12.
} 
universais, regras de caráter geral e absoluto, de origem religiosa, não podendo ser promulgadas com exclusividade na circunscrição de determinada nação.

\subsubsection{Influência jusnaturalista na composição dos direitos humanos}

Superada a visão religiosa da igualdade intrínseca entre os homens, a resposta que fundamenta a vigência de leis universais aplicáveis a todos os seres humanos sem qualquer distinção passou a ser a natureza. ${ }^{481}$ Mas, como observa Bobbio, "a natureza do homem revelou-se muito frágil como fundamento absoluto de direitos irresistíveis". ${ }^{482}$

As doutrinas jusnaturalistas a partir do século XVI foram de crucial importância para que, posteriormente, fossem reconhecidos os direitos fundamentais nos processos revolucionários do século XVIII. ${ }^{483}$

Perez Luño ensina que "com Locke, a defesa dos direitos naturais à vida, à liberdade e à propriedade converteu-se em fim prioritário da sociedade civil e em princípio legitimador básico do governo" e com Rousseau foi concebida "a formulação mais célebre da teoria do contrato social, para justificar mediante ela toda forma de poder no livre consentimento dos membros da sociedade. Este consentimento encontra sua expressão na vontade geral, cuja formação concorre cada cidadão em condições de igualdade, e que constitui o fundamento da lei entendida como instrumento para garantir e limitar a liberdade". 484

\subsubsection{Dos primeiros documentos à constitucionalização}

Paralelamente ao processo de elaboração doutrinária dos direitos humanos, foram produzidos inúmeros textos e documentos normativos, chamados de forma genérica de Cartas e Declaração de direitos, que introduziram paulatinamente direitos, deveres e liberdades individuais que culminaram na conformação atual dos direitos fundamentais. ${ }^{485}$

\footnotetext{
${ }^{481}$ COMPARATO, Fábio Konder. op. cit., 14.

${ }^{482}$ BOBBIO, Norberto. A era dos direitos, cit., p. 16.

${ }^{483}$ SARLET, Ingo Wolfgang. op. cit., p. 44.

${ }^{484}$ PEREZ LUÑO, Antonio Enrique. Los derechos fundamentales, cit., p. 31-32.

${ }^{485}$ Id. Ibid., p. 33.
} 
A partir do século XI, período que convencionalmente é denominado Baixa Idade Média, começa a surgir um movimento de reconstrução da unidade política perdida com a instauração do feudalismo e "volta a tomar corpo a idéia de limitação do poder dos governantes, pressuposto do reconhecimento, a ser feito somente alguns séculos depois, da existência de direitos comuns a todos os indivíduos, qualquer que fosse o estamento social - clero, nobreza e povo - no qual eles se encontrassem" 486.

Não há dúvida que o desenvolvimento dos direitos humanos está estreitamente vinculado a história dos povos, razão pela qual, dadas as circunstâncias sociais econômicas e culturais da Idade Média, na época os documentos legais não se referiam a direitos de toda a população, mas apenas de uma parcela desse todo. Era concedido algum privilégio patrimonial e de liberdade para um estamento ou a um território concreto. A exemplo disso, podemos citar a Magna Carta, documento outorgado em 1215 pelo monarca inglês João sem Terra e dirigida aos barões revoltados e circunscrito ao seu território. ${ }^{487}$

Na verdade, este documento foi um pacto firmado entre o rei João Sem-Terra, bispos e barões ingleses e "inobstante tenha apenas servido para garantir aos nobres barões ingleses alguns privilégios feudais, alijando, em princípio, a população do acesso aos 'direitos' consagrados no pacto, serviu como ponto de referência para alguns direitos e liberdades civis clássicos, tais como o habeas corpus, o devido processo legal e a garantia da propriedade". 488

Entre os preceitos da Magna Carta está o de que "nenhum homem livre será detido ou sujeito à prisão, ou privado dos seus bens, ou colocado fora da lei, ou exilado, ou de qualquer modo molestado, e nós não procederemos nem mandaremos proceder contra ele senão mediante um julgamento regular pelos seus pares ou de harmonia com a lei do país". ${ }^{489} \mathrm{O}$ legado de tal prescrição é que ela "seria quatro séculos mais tarde o ponto de partida para a Petition of Rights de 1628, e também do Habeas Corpus de 1679, que inclusive em nossos dias tutela a liberdade pessoal do súdito inglês". ${ }^{490}$

Apesar da sua irrefutável importância no processo de construção dos direitos humanos, a Magna Carta não foi o primeiro nem único documento normativo produzido na

\footnotetext{
${ }^{486}$ COMPARATO, Fábio Konder. op. cit., p. 43.

${ }^{487}$ LABRADA RUBIO, Valle. op. cit., p. 72.

${ }^{488}$ SARLET, Ingo Wolfgang. op. cit., p. 48.

${ }^{489}$ MAGNA CARTA $\quad-\quad 1215 . \quad$ Disponível em: <http://www.direitoshumanos.usp.br/counter/Doc_Histo/texto/Magna_Carta.html. Acesso em: 10 jan. 2009.

${ }^{490}$ PEREZ LUÑO, Antonio Enrique. Los derechos fundamentales, cit., p. 34.
} 
época. Perez Luño nos alerta que "durante o período medieval não faltam documentos em que o monarca, cujo poder é teoricamente ilimitado, reconhece alguns limites a seu exercício em favor da Igreja, dos senhores feudais ou das comunidades locais" ${ }^{491}$. Nos séculos XII e XIII Espanha e Portugal fornecem numerosos exemplos de cartas de franquia e liberdades em documentos outorgados pelos monarcas.

É importante ressaltar que as declarações inglesas do século XVII evidenciam uma evolução, pois partiu-se de liberdades e privilégios estamentais, isto é, de princípios limitadores do status social, jurídico e político do indivíduo sob uma perspectiva do direito privado para liberdades gerais no plano do direito público. Isso mostra uma ampliação significativa, não só em relação ao conteúdo das liberdades reconhecidas, mas também quanto à extensão da sua titularidade a todos os cidadãos ingleses. ${ }^{492}$

Não podemos esquecer, no entanto, que não obstante a "sua importância para a evolução no âmbito da afirmação dos direitos, inclusive como fonte de inspiração para outras declarações, esta positivação de direitos e liberdade civis na Inglaterra, apesar de conduzir a limitações do poder real em favor da liberdade individual, não pode, ainda, ser considerada como marco inicial, isto é, como o nascimento dos direitos fundamentais no sentido que hoje se atribui ao termo". 493

Os textos norte-americanos, entre os quais estão a Declaração da Virgínia e a Declaração da Independência, "incorporaram virtualmente os direitos e liberdades já reconhecidos pelas suas antecessoras inglesas do século XVII, direitos estes que também tinham sido reconhecidos aos súditos das colônias americanas, com a nota distintiva de que, a despeito da virtual identidade de conteúdo, guardaram as características da universalidade e supremacia dos direitos naturais, sendo-lhes reconhecida eficácia inclusive em relação à representação popular, vinculando, assim, todos os poderes públicos". 494

Declaração de Direitos do Bom Povo de Virgínia, de 16 de junho de 1776, proclama "que todos os homens são, por natureza, igualmente livres e independentes, e têm certos direitos inatos, dos quais, quando entram em estado de sociedade, não podem por qualquer acordo privar ou despojar seus pósteros e que são: o gozo da vida e da liberdade

\footnotetext{
${ }^{491}$ PEREZ LUÑO, Antonio Enrique. Los derechos fundamentales, cit., p. 33.

${ }^{492}$ Id. Ibid., p. 34-35.

${ }^{493}$ SARLET, Ingo Wolfgang. op. cit., p. 50.

${ }^{494}$ Id., loc. cit.
} 
com os meios de adquirir e de possuir a propriedade e de buscar e obter felicidade e segurança". 495

A Declaração de Independência dos Estados Unidos surgiu antes que se passasse um mês da primeira, em 04 de julho de 1776, consolida a separação das Colônias do governo britânico, dando início a um período constituinte para a elaboração da Constituição. A declaração afirma "que todos os homens são criados iguais, que são dotados pelo seu criador de certos direitos inalienáveis entre os quais está a vida, a liberdade e a busca pela felicidade". ${ }^{496}$

A Constituição dos Estados Unidos, aprovada em 17 de setembro de 1787, trata do funcionamento do Estado Federal, da distribuição e competência dos diferentes poderes. Os direitos humanos, por sua vez, são incorporados em 1791, por meio de dez emendas constitucionais. $^{497}$

Sob inspiração das declarações americanas e da doutrina iluminista francesa, foi proclamada a Declaração dos Direitos do Homem e do Cidadão, em 26 de agosto de 1789 pelos franceses. Ela foi o resultado da revolução que pôs fim ao antigo regime e iniciou o Estado burguês na França. Nela são declarados os "direitos naturais, inalienáveis e sagrados do homem", sendo que, no artigo $2^{\circ}$, fica esclarecido que "esses direitos são a liberdade, a prosperidade, a segurança e a resistência à opressão". O artigo $6^{\circ}$ da declaração estabelece a igualdade de todos perante a lei. ${ }^{498}$

As declarações americanas e francesas carregam algumas características em comum como a inspiração nos pressupostos racionalistas e contratualistas da escola do direito natural, o caráter universal dos direitos nelas consagrados, assim como, boa parte do conteúdo desses direitos cujo teor pode ser relacionado, sobretudo, às liberdades individuais. $^{499}$ É possível afirmar, portanto, que inequivocamente, pode-se admitir a "relação de reciprocidade, no que concerne à influência exercida por uma declaração de direitos sobre a outra", e a contribuição francesa, como "decisiva para o processo de

\footnotetext{
${ }^{495}$ DECLARAÇÃO DE DIREITOS DO BOM POVO DE VIRGÍNIA. Disponível em: $<$ http://www.direitoshumanos.usp.br/counter/Doc_Histo/texto/Povo_Virginia.html>. Acesso em: 10 jan. 2009.

${ }^{496}$ LABRADA RUBIO, Valle. op. cit., p. 85.

${ }^{497}$ Id. Ibid., p. 85-86.

${ }^{498}$ DECLARAÇÃO DE DIREITOS DO HOMEM E DO CIDADÃO. Disponível em: $<$ http://www.direitoshumanos.usp.br/counter/Doc_Histo/texto/Direitos_homem_cidad.html>. Acesso em: 10 jan. 2009.

${ }^{499}$ PEREZ LUÑO, Antonio Enrique. Los derechos fundamentales, cit., p. 36.
} 
constitucionalização e reconhecimento de direitos e liberdades fundamentais nas Constituições do século XIX" ${ }^{500}$.

Foi, justamente, ao longo do século XIX que o proletariado entra em cena como protagonista histórico, pois, à medida do crescimento do processo de industrialização, desenvolve-se uma consciência de classe, que reivindica direitos econômicos e sociais, para compor, juntamente com os clássicos direitos individuais, resultado do triunfo da revolução liberal burguesa, o elenco dos direitos humanos, como ocorreu mais tarde na Constituição Mexicana de 1917, considerada o primeiro intento de conciliar os direitos de liberdade como os direitos sociais, superando assim os pólos opostos do individualismo e do coletivismo, seguida da Constituição de Weimar, de 1919. Esta última, serviu de inspiração para as Constituições que objetivaram conjugar em seu sistema de direitos fundamentais as liberdades com os direitos econômicos, sociais e culturais. ${ }^{501}$

\subsubsection{Internacionalização dos direitos humanos}

A atual etapa de positivação dos direitos humanos não pode deixar de admitir a valiosa contribuição do fenômeno da internacionalização desses direitos, ou seja, do processo ligado ao reconhecimento da subjetividade jurídica do indivíduo pelo direito internacional. Sua importância reside no fato de que qualquer atentado contra os direitos e liberdades da pessoa não mais é considerada uma "questão doméstica" dos Estados, mas um problema de relevância internacional. ${ }^{502}$

O Direito Humanitário, a Liga das Nações e a Organização Internacional do Trabalho podem ser considerados os precedentes históricos do processo de internacionalização dos direitos humanos, ou seja, representam marcos do seu desenvolvimento, no qual ocorre uma redefinição do âmbito e do alcance do conceito clássico de soberania estatal, relativizando-o ao impor limites à liberdade e à autonomia dos Estados ao incorporar compromissos e obrigações ao nível internacional em relação aos direitos humanos. ${ }^{503}$

\footnotetext{
${ }^{500}$ SARLET, Ingo Wolfgang. op. cit., p. 51-52.

${ }^{501}$ PEREZ LUÑO, Antonio Enrique. Los derechos fundamentales, cit., p. 38-40.

${ }^{502}$ Id. Ibid., p. 41.

${ }^{503}$ PIOVESAN, Flávia. Direitos humanos e o direito constitucional internacional, cit., p. 123-128.
} 
Enquanto no primeiro são fixados limites à atuação dos Estados com o objetivo de assegurar a observância dos direitos humanos em hipótese de guerra, na Convenção da Liga das Nações, após a Primeira Guerra Mundial, havia previsões genéricas sobre os direitos humanos, que incluíam medidas voltadas aos parâmetros internacionais de direito ao trabalho, com o compromisso dos Estados em assegurar condições justas e dignas de trabalho para homens, mulheres e crianças, sob pena do estabelecimento de sanções econômicas e militares impostas pela comunidade internacional àqueles Estados que não cumprissem tais obrigações.

A Organização Internacional do Trabalho, assim como as duas últimas, também contribuiu para com o processo de internacionalização dos direitos humanos. Esse organismo internacional foi criado também após a Primeira Guerra Mundial com o intuito de promover padrões internacionais de condições de trabalho e bem estar.

Apesar desses precedentes históricos, após a Segunda Guerra Mundial o processo de generalização da proteção dos direitos humanos foi desencadeado no plano internacional a partir da adoção, em 1948, da Declaração Universal dos Direitos Humanos. A preocupação na época, em virtude do que ocorrera no holocausto, era a da restauração do direito internacional mediante o reconhecimento processual dos indivíduos ou grupos sociais no plano internacional. Como observa Cançado Trindade, “já não se trata de proteger indivíduos sob certas condições ou situações circunscritas como no passado (e.g., proteção de minorias, de habitantes de territórios sob mandato, de trabalhadores sob as primeiras convenções da Organização Internacional do Trabalho - OIT), mas doravante de proteger o ser humano como tal". 504

A Declaração Universal de 1948, sob uma perspectiva histórica, tem um significado muito relevante, sobretudo, porque apresentou uma concepção integral ou holística de todos os direitos humanos, situando num mesmo plano todas as "categorias" de direitos (civis, políticos, econômicos, sociais e culturais). Essa concepção foi retomada mais adiante na I Conferência Mundial de Direitos Humanos, de 1968, e na II Conferência Mundial de Direitos Humanos, de 1993. Entre os direitos proclamados estão "os de caráter pessoal, os atinentes às relações do indivíduo com os grupos e o mundo exterior, as

\footnotetext{
${ }^{504}$ TRINDADE, Antônio Augusto Cançado. O legado da Declaração Universal e o futuro da proteção internacional dos direitos humanos. In: AMARAL JÚNIOR, Alberto do; PERRONE-MOPISÉS, Cláudia (Orgs.). O cinqüentenário da Declaração Universal dos Direitos do Homem. São Paulo: Edusp, 1999. p. 15.
} 
liberdades públicas e os direitos políticos, assim como os direitos econômicos, sociais e culturais". 505

Bobbio assevera que os direitos elencados na Declaração de 1948 "não são os únicos e possíveis direitos do homem: são os direitos do homem histórico, tal como este se configura na mente dos redatores da Declaração após a tragédia da Segunda Guerra Mundial, numa época que tivera início com a Revolução Francesa e desembocara na Revolução Soviética. Não é preciso muita imaginação para prever que o desenvolvimento da técnica, a transformação das condições econômicas e sociais, a ampliação dos conhecimentos e a intensificação dos meios de comunicação poderão produzir tais mudanças na organização da vida humana e das relações sociais que se criem ocasiões favoráveis para o nascimento de novos carecimentos e, portanto, para novas demandas de liberdade e de poderes". 506

Contudo, não podemos negar a importância da Declaração de 1948 para a construção dos direitos humanos ao longo da história, pois ela representa um marco neste processo e, além disso, uma referência para o direito internacional global e regional, bem como, uma influência positiva para o direito interno dos Estados. Caçado Trindade observa que "a Declaração Universal também se projetou no direito interno dos Estados. Suas normas encontram expressão nas Constituições nacionais de numerosos Estados e serviram de modelo a disposições das legislações nacionais visando à proteção dos direitos humanos". 507

Seguiram-se à Declaração Universal dos Direitos Humanos outros importantes documentos como, em 1966, o Pacto Internacional sobre Direitos Políticos Econômicos, Sociais e Culturais e o Pacto Internacional sobre Direitos Civis e Políticos, ambos adotados pela Assembléia-Geral das Nações Unidas.

\subsubsection{Gerações de direitos humanos}

Os direitos humanos, em uma perspectiva histórica, podem ser agrupados em três gerações, sob a inspiração da Revolução Francesa cujos ideais eram liberdade, igualdade e fraternidade. Os direitos de primeira geração corresponderiam aos direitos de liberdade e

\footnotetext{
${ }^{505}$ TRINDADE, Antônio Augusto Cançado. op. cit., p. 18.

${ }^{506}$ BOBBIO, Norberto. A era dos direitos, cit., p. 33.

${ }^{507}$ TRINDADE, Antônio Augusto Cançado. op. cit., p. 25.
} 
individuais; os de segunda geração, aos direitos de igualdade e econômico-sociais; os de terceira geração, aos direitos de solidariedade. Há quem defenda, inclusive, a existência de uma quarta geração e, até mesmo, de uma quinta e sexta gerações. ${ }^{508}$

Paulo Bonavides assevera que "o lema revolucionário do século XVII, esculpido pelo gênio francês, exprimiu em três princípios cardeais todo o conteúdo possível dos direitos fundamentais, profetizando até mesmo a sequiência histórica de sua gradativa institucionalização: liberdade, igualdade e fraternidade". 509

Antes de prosseguirmos, é importante lembrar que, apesar de haver uma discordância na doutrina sobre a nomenclatura "gerações", por uma questão de clareza, já que esta forma se tornou comum, optamos por mantê-la, porém, mais adiante iremos esclarecer as razões das críticas que lhe são feitas.

Essa classificação resulta de um olhar mais demorado sobre a positivação desses direitos, pois "somente a partir do reconhecimento e da consagração dos direitos fundamentais pelas primeiras Constituições é que assume relevo a problemática das assim denominadas "gerações" (ou dimensões) ${ }^{510}$ dos direitos fundamentais, visto que umbilicalmente vinculada às transformações geradas pelo reconhecimento de novas necessidades básicas, de modo especial em virtude de evolução do Estado Liberal (Estado formal de Direito) para o moderno Estado de Direito (Estado social e democrático [material] de Direito), bem como pelas mutações decorrentes do processo de industrialização e seus reflexos, pelo impacto tecnológico e científico, pelo processo de descolonização e tantos outros fatores direta ou indiretamente relevantes neste contexto e que poderiam ser considerados", 511

Norberto Bobbio afirma que "o desenvolvimento dos direitos do homem passou por três fases: num primeiro momento, afirmaram-se os direitos de liberdade, isto é, todos aqueles direitos que tendem a limitar o poder do Estado e a reservar para o indivíduo, ou para os grupos particulares, uma esfera de liberdade em relação ao Estado; num segundo momento, foram propugnados os direitos políticos, os quais - concebendo a liberdade não apenas negativamente, como não-impedimento, mas positivamente, como autonomia tiveram como conseqüência a participação cada vez mais ampla, generalizada e freqüente

\footnotetext{
${ }^{508}$ SARLET, Ingo Wolfgang. op. cit., p. 52.

${ }^{509}$ BONAVIDES, Paulo op. cit., p. 516.

${ }^{510}$ Ingo Wolfgang Sarlet prefere utilizar a expressão "dimensões de direitos" ao invés de "gerações de direitos".

${ }^{511}$ SARLET, Ingo Wolfgang. op. cit., p. 43.
} 
dos membros de uma comunidade no poder político (ou liberdade no Estado); finalmente, foram proclamados os direitos sociais, que expressam o amadurecimento de novas exigências - podemos mesmo dizer, de novos valores -, como os do bem-estar e da igualdade não apenas formal, e que poderíamos chamar de liberdade através ou por meio do Estado". ${ }^{512}$ A preocupação com a qualidade de vida geral e, sobretudo, daqueles que ainda estão para nascer, além de que, na atualidade, a em meio ao processo de internacionalização dos direitos humanos poderíamos falar, usando a linguagem do autor como referência, em liberdades para além do Estado.

Cançado nos adverte que "quem formulou a tese das gerações de direito foi o Karel Vasak, em conferência ministrada em 1979, no Instituto Internacional de Direitos Humanos, em Estrasburgo. Pela primeira vez, ele falou em gerações de direitos, inspirado na bandeira francesa: liberté, egalité, fraternitê" e, posteriormente, foi adota e difundida por Norberto Bobbio. ${ }^{513}$

A seguir, como era de se esperar, iremos analisar, mais detidamente, os direitos humanos dentro dessa classificação das gerações de direito, bem como, a posição ocupada pelo direito de greve no seu seio.

\subsubsection{Direitos de primeira geração}

Entende-se por direitos de primeira geração "os direitos de liberdade, os primeiros a constarem do instrumento normativo constitucional, a saber, os direitos civis e políticos, que em grande parte correspondem, por um prisma histórico, àquela fase inaugural do constitucionalismo do Ocidente". 514 Esses direitos já estão consolidados no plano da universalidade formal, pois qualquer Constituição que pretenda ser digna de assim ser denominada os apresenta no seu rol de direitos fundamentais. Eles têm como característica principal serem direitos de resistência ou de oposição do indivíduo em relação ao Estado.

O liberalismo, moldado na luta contra o absolutismo, defendia a limitação dos poderes do Estado com o objetivo de prevenir um abuso sobre os direitos dos cidadãos

\footnotetext{
${ }^{512}$ BOBBIO, Norberto. A era dos direitos, cit., p. 32.

${ }^{513}$ TRINDADE, Antônio Augusto Cançado. Cançado Trindade questiona a tese de "gerações de direitos humanos" de Norberto $\quad$ Bobbio. Disponível em: <http://www.dhnet.org.br/direitos/militantes/cancadotrindade/cancado_bob.htm>. Acesso em: 12 jan. 2009.

${ }^{514}$ BONAVIDES, Paulo op. cit., p. 517.
} 
com a interferência estatal na sua esfera privada. Os direitos defendidos na "tradição liberal têm o seu núcleo central nos assim chamados 'direitos de liberdade', que são fundamentalmente os direitos do indivíduo (burguês) à vida, à liberdade, à propriedade, à segurança. O Estado limita-se à garantia dos direitos individuais através da lei sem intervir ativamente na sua promoção. Por isto, estes direitos de liberdade negativa, porque têm como objetivo a não intervenção do Estado na esfera dos direitos individuais". ${ }^{515}$

Além dos direitos de notória inspiração jusnaturalista, como aqueles relacionados à vida, à liberdade, à propriedade e à igualdade perante à lei, complementam o rol dos direitos de primeira geração "um leque de liberdades, incluindo as assim denominadas liberdades de expressão coletiva (liberdades de expressão, imprensa, manifestação, reunião, associação, etc.) e pelos direitos de participação política, tais como o direito de voto e a capacidade eleitoral passiva, revelando, de tal sorte, a íntima correlação entre os direitos fundamentais e a democracia. Também o direito de igualdade, entendido como igualdade formal (perante a lei) e algumas garantia processuais (devido processo legal, habeas corpus, direito de petição) se enquadram nesta categoria". 516

\subsubsection{Direitos de segunda geração}

Os direitos de segunda geração desenvolvem-se no século XX e correspondem aos "direitos sociais, culturais e econômicos bem como os direitos coletivos ou de coletividades, introduzidos no constitucionalismo das distintas formas de Estado social, depois que germinaram por obra da ideologia e da reflexão antiliberal deste século. Nasceram abraçados ao princípio da igualdade, do qual não se podem separar, pois fazê-lo equivaleria a desmembrá-los da razão de ser que os ampara e estimula". ${ }^{517}$ Esses direitos, assim como os de primeira geração, foram, inicialmente, objeto de especulações filosóficas e políticas e, posteriormente, dominaram as Constituições do segundo pós-guerra, inspiradas, sobretudo pela Constituição de Weimar, de 1919, e foram objeto de vários pactos internacionais. No entanto, eles já figuraram, certo que, de forma embrionária e

\footnotetext{
${ }^{515}$ TOSI, Giuseppe. História conceitual dos direitos humanos. In: TOSI, Giuseppe (Org.). Direitos humanos: história, teoria e prática. João Pessoa: Ed. Universitária, 2005. p. 113.

${ }^{516}$ SARLET, Ingo Wolfgang. op. cit., p. 54.

${ }^{517}$ BONAVIDES, Paulo op. cit., p. 518.
} 
isolada, nas Constituições Francesas de 1793 e 1848, na Constituição Brasileira de 1824 e na Constituição Alemã de 1848. ${ }^{518}$

A luta da classe trabalhadora durante todo o século XIX e grande parte do século XX exigiu a ampliação dos direitos civis e políticos. Além disso, os movimentos socialistas e social-democráticos "introduziram também um novo conjunto de direitos, desconhecidos e alheios ao liberalismo: os direitos de igualdade, ou econômicos e sociais, direitos eminentemente coletivos, enquanto direitos de liberdade eram eminentemente individuais: ou seja, uma democracia não somente política, mas social". ${ }^{519}$

No entanto, os direitos sociais quando tomados em um sentido amplo também "se reportam à pessoa individual, não podendo ser confundidos com os direitos coletivos e/ou difusos da terceira dimensão. A utilização da expressão 'social' encontra justificativa, entre outros aspectos que não cabe aprofundar neste momento, na circunstância de que os direitos da segunda dimensão podem ser considerados uma densificação do princípio da justiça social, além de corresponderem a reivindicações das classes menos favorecidas, de modo especial da classe operária, a título de compensação, em virtude da extrema desigualdade que caracterizava (e, de certa forma, ainda caracteriza) as relações com a classe empregadora, notadamente detentora de um maior ou menor grau de poder econômico". 520

É importante observar que os direitos de segunda geração "não englobam apenas direitos de cunho positivo, mas também as denominadas 'liberdades sociais', do que dão conta os exemplos da liberdade de sindicalização, do direito de greve, bem como do reconhecimento dos direitos fundamentais aos trabalhadores, tais como o direito a férias e ao repouso semanal remunerado, a garantia de um salário mínimo, a limitação da jornada de trabalho, apenas para citar alguns dos mais representativos". 521

É possível identificar uma diferença bastante importante quanto à exigência feita em relação à postura do Estado nestes dois períodos em que houve a constitucionalização dos direitos de primeira e segunda gerações, pois "na luta contra o absolutismo, o liberalismo considerava o Estado como um mal necessário e mantinha uma relação de intrínseca desconfiança: a questão central era a garantia das liberdades individuais contra a intervenção do Estado nos assuntos particulares. Agora, ao contrário, tratava-se de obrigar

\footnotetext{
${ }^{518}$ SARLET, Ingo Wolfgang. op. cit., p. 55.

${ }^{519}$ TOSI, Giuseppe. op. cit., p. 116-117.

${ }^{520}$ SARLET, Ingo Wolfgang. op. cit., p. 55-56.

${ }^{521}$ Id. Ibid., p. 55.
} 
o Estado a fornecer um certo número de serviços para diminuir as desigualdades econômicas e sociais e permitir a efetiva participação, de todos os cidadãos, na vida e no 'bem-estar' social. Podemos ler este processo também como uma predominância de concepção 'democrática' e republicana do Estado de Direito sobre uma concepção estritamente liberal". 522

\subsubsection{Direitos de terceira geração}

Os direitos de terceira geração, por sua vez, tendem a cristalizar-se no fim do século XX e assentam se sobre o princípio da fraternidade. Surgiram "da reflexão sobre temas referentes ao desenvolvimento, à paz, ao meio-ambiente, à comunicação e ao patrimônio comum da humanidade". 523

Os chamados direitos fundamentais de terceira geração têm como elemento distintivo o fato de terem "como titular não o indivíduo na sua singularidade, mas sim grupos humanos como a família, o povo, a nação, coletividades regionais ou étnicas e a própria humanidade". ${ }^{524}$ Entre os direitos de terceira geração mais citados está o direito à paz, à autodeterminação dos povos, ao desenvolvimento, ao meio ambiente e qualidade de vida, além do direito à conservação e utilização do patrimônio histórico e cultural e o direito de comunicação. A característica que distingue estes direitos dos demais é a sua titularidade coletiva, na maioria das vezes, indefinida e indeterminável. Eles são também chamados direitos de solidariedade ou de fraternidade, mormente "em face de sua implicação universal ou, no mínimo, transindividual, e por exigirem esforços e responsabilidades em escala até mesmo mundial para sua efetivação". ${ }^{525}$

\footnotetext{
${ }^{522}$ TOSI, Giuseppe. op. cit., p. 117-118.

${ }^{523}$ BONAVIDES, Paulo op. cit., p. 523.

${ }^{524}$ LAFER, Celso. A reconstrução dos direitos humanos: um diálogo com o pensamento de Hannah Arendt. São Paulo: Cia. das Letras, 2001. p. 131.

${ }^{525}$ SARLET, Ingo Wolfgang. op. cit., p. 56-57.
} 


\subsubsection{Direitos de quarta geração}

Muito embora pareça adequada "a idéia de que, na essência, todas as demandas na esfera dos direitos fundamentais gravitam, direita ou indiretamente, em torno dos tradicionais e perenes valores da vida, liberdade, igualdade e fraternidade (solidariedade), tendo, na base, o princípio maior da dignidade da pessoa", ${ }^{526}$ existem aqueles que se posicionam a favor da existência de uma quarta geração de direitos. Paulo Bonavides defende que os direitos de quarta geração correspondem à derradeira fase de institucionalização do Estado social e é introduzida pela globalização política na esfera da normatividade jurídica. Entre os direitos de quarta geração estão "o direito à democracia, o direito à informação e o direito ao pluralismo. Deles depende a concretização da sociedade aberta do futuro, em sua dimensão de máxima universalidade, para a qual parece o mundo inclinar-se no plano de todas as relações de convivência". 527

\subsubsection{Críticas à teoria da geração de direitos}

A classificação dos direitos humanos em gerações é criticada por parte da doutrina. Entre as críticas aparece o equívoco de linguagem representado pela escolha inadequada das palavras. O emprego do termo "gerações" pode levar ao entendimento de que os direitos agrupados em cada uma das gerações se sucedem no tempo o que contraria a idéia de cumulatividade, própria dos direitos humanos.

Argumenta-se que “o vocábulo 'dimensão' substitui, com vantagem lógica e qualitativa, o termo 'geração', caso este último venha a induzir apenas sucessão cronológica e, portanto, suposta caducidade dos direitos das gerações antecedentes, o que não é verdade. Ao contrário, os direitos da primeira geração, direitos individuais, os da segunda, direitos sociais, e os da terceira, direitos ao desenvolvimento, ao meio ambiente, à paz e à fraternidade, permanecem eficazes, são infra-estruturais, formam a pirâmide cujo ápice é o direito à democracia; coroamento daquela globalização política para a qual, como

\footnotetext{
${ }^{526}$ SARLET, Ingo Wolfgang. op. cit., p. 58.

${ }^{527}$ BONAVIDES, Paulo op. cit., p. 524-525.
} 
no provérbio chinês da grande muralha, a Humanidade parece caminhar a todo vapor, depois de haver dado o seu primeiro passo". 528

A finalidade da distinção dos direitos fundamentais em gerações é, segundo alguns autores, apenas de situar os diferentes momentos em que esses direitos são acolhidos pela ordem jurídica e que isso não impede o seu caráter cumulativo de evolução no decorrer do tempo, pois eles formam uma unidade, uma vez que têm como característica a indivisibilidade.

Cançado Trindade é um dos que critica o uso dessa classificação e argumenta que: (i)"essa teoria é fragmentadora, atomista e toma os direitos de maneira absolutamente dividida, o que não corresponderia à realidade", pois há, segundo ele, direitos que se inserem em mais de uma geração, sendo assim, impossível enquadrar os direitos fundamentais nesta classificação; (ii) a tese não corresponde à verdade histórica, pois a "conceituação de que primeiro vieram os direitos individuais e, nesta ordem, os direitos econômico-sociais e o direito de coletividade correspondem à evolução do direito constitucional. É verdade que isso ocorreu no plano dos direitos internos dos países, mas no plano internacional a evolução foi contrária. No plano internacional, os direitos que apareceram primeiro foram os econômicos e os sociais. As primeiras convenções da OIT anteriores às Nações Unidas, surgiram nos anos 20 e 30. O direito ao trabalho, o direito às condições de trabalho é a primeira geração, do ponto de vista do direito internacional". ${ }^{529}$

Tais críticas se justificam, pois, como deve ser lembrado "os direitos sociais foram objeto de duas convenções internacionais do trabalho adotadas em Berna, já em 1905 e 1906. A atuação normativa de Organização Internacional do Trabalho se iniciou em 1921, por meio de convenções e reconvenções internacionais do trabalho que inspiraram diversas passagens da própria Declaração Universal dos Direitos Humanos". 530

\footnotetext{
${ }^{528}$ BONAVIDES, Paulo op. cit., p. 525.

${ }^{529}$ TRINDADE, Antônio Augusto Cançado. Cançado Trindade questiona a tese de "gerações de direitos humanos" de Norberto Bobbio, cit.

${ }^{530}$ SILVA, Walküre Lopes Ribeiro. Liberdade sindical no contexto dos direitos humanos: a experiência da OIT, cit., p. 206-207.
} 


\subsection{O exercício do direito de greve como efetivação dos direitos humanos}

A liberdade de associação é consagrada na Constituição como uma das espécies dos direitos fundamentais. Ao lado da igualdade, ela forma os "elementos essenciais do conceito de dignidade da pessoa humana, que o constituinte erigiu à condição de fundamento do Estado Democrático de Direito e vértice do sistema dos direitos fundamentais". 531

As associações em sentido amplo são originadas da coligação das pessoas entre si com caráter estável, sob direção comum, para fins lícitos. É importante frisar que "a liberdade de associação presta-se a satisfazer necessidades várias dos indivíduos, aparecendo, ao constitucionalismo atual, como básica para o Estado Democrático de Direito. Quando não podem obter os bens da vida que desejam, por si mesmo, os homens somam esforços, e a associação é a fórmula para tanto (...) o direito de associação está vinculado ao preceito de proteção da dignidade da pessoa, aos princípios de livre iniciativa, da autonomia da vontade e da garantia da liberdade de expressão". 532

Walküre Lopez Ribeiro da Silva afirma que "está claro que a liberdade sindical é espécie da qual a liberdade de associação é gênero e que ambas fazem parte das liberdades civis. ${ }^{533}$ Portanto, tal qual ocorre com a liberdade de associação em geral, a liberdade sindical configura um direito fundamental, pois, até mesmo, da própria definição de sindicato podemos concluir que ele é espécie cujo gênero é a associação, conforme procuraremos demonstrar a seguir.

Octavio Bueno Magano define sindicato como "a associação de pessoas físicas ou jurídicas, que exercem atividade profissional ou econômica, para a defesa dos respectivos interesses". ${ }^{534}$ A natureza jurídica do sindicato é a de associação, pois o sindicato agrupa pessoas voltadas, de modo contínuo, a alcançar seus objetivos comuns. A necessidade de incluir na definição de sindicato pessoas físicas ou jurídicas não descaracteriza a sua natureza jurídica, pois tal inclusão decorre da existência de sindicatos de empregadores. Os objetivos comuns a serem alcançados espelham os interesses a serem defendidos pelos

\footnotetext{
${ }^{531}$ MENDES, Gilmar Ferreira; COELHO, Inocêncio Mártires; BRANCO, Paulo Augusto Gonet. op. cit., p. 349.

${ }^{532}$ Id. Ibid., p. 391.

${ }^{533}$ SILVA, Walküre Lopes Ribeiro. Liberdade sindical no contexto dos direitos humanos: a experiência da OIT, cit., p. 208.

${ }^{534}$ MAGANO, Octavio Bueno. Direito coletivo do trabalho, cit., p. 96.
} 
trabalhadores ou empregadores como manifestação da autonomia da associação profissional ou econômica em função da sua condição de ente privado. ${ }^{535}$

A liberdade sindical, portanto, assim como a liberdade de associação, é um direito fundamental decorrente da sua condição de liberdade civil. Mesmo porque, a finalidade do sindicato é defender os interesses dos seus representados, trabalhadores ou empregadores. Em relação aos primeiros, a defesa dos interesses converge no sentido da preservação da dignidade do homem trabalhador, razão mais que suficiente para justificar a natureza fundamental desse direito.

Jean Rivero assevera que a greve é intrinsecamente ligada à liberdade sindical, ocupando, entre as formas contemporâneas de ação coletiva, um lugar de destaque. ${ }^{536}$ Magano nos ensina que "num sistema de liberdade sindical, em que os grupos gozam de autonomia para a autodeterminação de seus interesses, é natural que cada um deles tente usar dos meios de pressão que lhes parecem mais convenientes para o sucesso de seus objetivos" 537 e, entre os meios mais utilizados, podemos destacar a greve. A greve, ainda na lição do mencionado autor, "apresenta-se como expressão objetiva da ação dos trabalhadores". ${ }^{538}$ Sendo assim, não há como se falar em liberdade sindical sem direito de greve, pois este integra a própria liberdade sindical.

Giovanni Orlandini assegura que o direito de greve representa para os trabalhadores o instrumento indispensável para oporem-se ao poder dos empregadores e serve-se das palavras de Kahn-Freund para mostrar a importância desse direito ao afirmar que na relação entre trabalho e capital, "do lado do trabalho, todo o poder é poder coletivo". 539

Entre as teorias apontadas pela doutrina para a qualificação jurídica do direito de greve podemos identificar aquela que defende a greve como direito absoluto da pessoa ou como direito de liberdade ou como direito político. Neste sentido há uma dilatação do direito de greve que não apenas tem como objetivo a obtenção de um determinado tratamento econômico-normativo por parte dos empregadores, mas se apresenta como

\footnotetext{
${ }^{535}$ MAGANO, Octavio Bueno. Direito coletivo do trabalho, cit., p. 96-99.

${ }^{536}$ RIVERO, Jean. Les libertes publiques: le regime des principales libertes. Paris: Press Universitaires de France; Thémis, 1977. p. 373.

${ }^{537}$ MAGANO, Octavio Bueno. Direito coletivo do trabalho, cit., p. 155.

${ }^{538}$ Id. Ibid., p. 186.

${ }^{539}$ Apud ORLANDINI, Giovanni. Sciopero e servizi pubblici essenziali nel processo d'integrazione europea: uno studio di diritto comparato e comunitario. Torino: G. Giappichelli, 2003. p. 3.
} 
meio de desenvolvimento da pessoa do trabalhador e de promoção da sua participação na vida política, econômica e social do país. ${ }^{540}$

Ingo Wolfgang Sarlet defende que os direitos fundamentais podem ser divididos em dois grupos principais levando-se em consideração as suas funções preponderantes, isto é, eles podem ser agrupados em direitos de defesa e direitos a prestações. Os direitos de defesa são integrados, sobretudo, pelos direitos de liberdade, igualdade, direitos-garantia, garantias institucionais, direitos políticos e posições jurídicas fundamentais em geral. Esses direitos, na maioria das vezes, reclamam uma atitude de abstenção dos poderes estatais em relação à esfera da autonomia pessoal, exigem, portanto, uma postura omissiva do Estado, visando a sua limitação. Os direitos a prestações, por sua vez, tem por objetivo uma conduta positiva do Estado (ou particulares destinatários da norma) na esfera econômica e social, visando à realização de igualdade material, ou seja, garantir ampla participação na distribuição de bens materiais e imateriais. É importante observar que os direitos sociais, de acordo com esta classificação, podem ser divididos em direitos a prestações materiais sociais, isto é, direitos a prestações em sentido estrito, e direitos sociais equiparados aos direitos de defesa, denominados liberdades sociais. ${ }^{541}$

O autor defende a existência do "postulado otimizador da máxima eficácia possível, bem como a presunção em favor da aplicabilidade imediata e da plenitude eficacial dos direitos fundamentais, decorrente da norma contida no art. $5^{\circ}, \S 1^{\circ}$, da nossa Constituição (...) tanto no que diz respeito aos direitos de defesa, quanto no que concerne aos direitos prestacionais", se bem que em relação aos primeiros, essa posição não costuma ser questionada, como ocorre com os direitos sociais, sobretudo aqueles considerados na sua dimensão prestacional. ${ }^{542}$

Entre os direitos econômicos e sociais estão o direito ao trabalho; a fixação de um salário mínimo; o estabelecimento de um limite máximo para a duração do trabalho; o amparo ao desemprego; a proteção à mulher e ao menor; o auxílio em caso de doença, invalidez; a concessão de aposentadoria; a garantia de acesso à educação; o direito de formar sindicatos; de liberdade sindical; o direito de greve. ${ }^{543}$

\footnotetext{
${ }^{540}$ GALANTINO, Luisa. op. cit.

${ }^{541}$ SARLET, Ingo Wolfgang. op. cit., p. 292-302.

${ }^{542}$ Id. Ibid., p. 292-293.

${ }^{543}$ SANTOS, Enoque Ribeiro dos. Direitos humanos na negociação coletiva: teoria e prática jurisprudencial, cit., p. 49.
} 
O direito de greve como categoria de direito social depende da relação entre seu exercício e o princípio da igualdade substancial, sendo que o seu reconhecimento se apóia em uma desigualdade de fato na relação entre capital e trabalho e de um status de fragilidade sócio-econômica de seu titular, que se pretende superar ou, ao menos, limitar mediante a sua concretização. $\mathrm{O}$ direito de greve como direito de liberdade, inserido na Constituição, não exige a mediação do legislador para tornar concreta a sua atuação, pois a norma que a reconhece contém um preceito auto-aplicativo, permitindo ao seu titular o direito de agir em juízo contra ato ou comportamento de privados que impeçam o seu exercício. $^{544}$

Ingo Wolfgang Sarlet sustenta que o direito de greve dos servidores públicos é "um típico direito de defesa (no caso, uma liberdade social)" 545 e que por trata-se de um “direito fundamental de defesa, uma atuação do legislador poderá até ser importante, mas sua ausência - mesmo diante de remissão expressa por parte do Constituinte - não constitui forçosamente um obstáculo para a aplicação direta da norma (...) não haveria razão para deixar de se reconhecer pelo menos outros possíveis efeitos que poderiam ser deduzidos diretamente da norma constitucional". 546

$\mathrm{O}$ autor sustenta que a melhor alternativa para garantir que o direito de greve dos servidores públicos previstos no texto constitucional seja diretamente aplicável e plenamente eficaz é "considerar que a circunstância de que a Constituição remeteu a concretização do direito em questão ao legislador (não apenas para fins de eventual restrição) reconhecendo, todavia, que, em face da desnecessidade de qualquer outra providência, a não ser a edição da norma legal reclamada pelo Constituinte, haveria de prevalecer a presunção decorrente do art. $5^{\circ}$, art. $1^{\circ}$, da $\mathrm{CF}$, que, atuando como mandado de otimização, autorizaria, mediante o recurso ao Mandado de Injunção (independentemente de uma declaração, em abstrato, da inconstitucionalidade por omissão), fosse, desde já assegurada judicialmente aos particulares a efetiva fruição da liberdade fundamental". ${ }^{547}$

Raimundo Simão de Melo afirma: "porque se trata o direito de greve de um direito fundamental, cuja interpretação das normas pertinentes deve, ao contrário de restringir o direito, buscar a sua concretização, extensão, ampliação e aplicação imediata,

\footnotetext{
${ }^{544}$ ORLANDINI, Giovanni. op. cit., p. 18.

${ }^{545}$ SARLET, Ingo Wolfgang. op. cit., p. 295.

${ }^{546}$ Id. Ibid., p. 296.

${ }^{547}$ Id. Ibid., p. 297.
} 
como estabelece o $\S 1^{\circ}$ do art. $5^{\circ}$ da Constituição e ensina a praxe interpretativa constitucional". 548

O objetivo primordial da greve é alcançar a melhoria das condições sociais do trabalhador e a sua posição de trabalhador não descaracteriza a humanidade. Sendo assim, a greve, seguramente, é um direito fundamental do trabalhador, enquanto pessoa humana. Carlos Henrique Bezerra Leite observa que "a greve constitui um instrumento democrático a serviço da cidadania, na medida em que seu objetivo maior consiste na reação pacífica e ordenada dos trabalhadores contra os atos que impliquem direita ou indiretamente desrespeito à dignidade da pessoa humana". 549

A Declaração Universal dos Direitos do Homem não fazem referência expressa ao direito de greve, no entanto, o direito de sindicalização proclamado no artigo XXIII, número 4, deixa implícito o direito de greve, uma vez que é por meio dela, principalmente, que os trabalhadores podem proteger os seus interesses, quando coletivamente organizados. O Pacto Internacional sobre Direitos Econômico, Sociais e Políticos, cujo papel principal é "a proteção das classes ou grupos sociais desfavorecidos, contra a dominação socioeconômica exercida pela minoria rica e poderosa", ${ }^{550}$ expressamente, proclama esse direito em seu artigo $8^{\circ}$, número $1, d$.

Surpreendentemente, a Organização Internacional do Trabalho não produziu nenhuma convenção ou recomendação que trate especificamente sobre o direito de greve. No entanto, é possível afirmar que, indiretamente, as Convenções n. 87 e n.98 reconhecem esse direito.

Além disso, por muitas ocasiões esse direito tem sido reconhecido por meio dos órgãos de controle e aplicação das normas da Organização Internacional do Trabalho, o Comitê de Liberdade Sindical e a Comissão de Peritos. Esses órgãos produziram uma extensa jurisprudência, reconhecendo o direito de greve como um direito fundamental dos trabalhadores e de suas organizações e, também, delimitando o alcance dessas disposições. ${ }^{551}$

Como exemplo, podemos citar o Verbete 520 da OIT: "O Comitê de Liberdade Sindical tem considerado sempre que o direito de greve é um dos direitos fundamentais dos

\footnotetext{
${ }^{548}$ MELO, Raimundo Simão de. op. cit., p. 54.

${ }^{549}$ LEITE, Carlos Henrique Bezerra. A greve do servidor público civil e os direitos humanos. LTr: revista legislação do trabalho, São Paulo, v.65, n.12, p. 1462, dez. 2001.

${ }^{550}$ COMPARATO, Fábio Konder. op. cit., p. 335.

${ }^{551}$ GERNIGON, Bernard; ODERO, Alberto; GUIDO, Horacio. Princípios de la OIT sobre la huelga, cit., p. 8.
} 
trabalhadores e de suas organizações unicamente na medida em que constitui um meio de defesa de seus interesses econômicos."

Muito embora fosse de se esperar que o direito de greve fosse reconhecido de forma unânime em todas as constituições ocidentais modernas, sobretudo, em razão do projeto de Estado social desenvolvido sob inspiração do contexto vivenciado após a Segunda Guerra mundial, não é o que ocorre. Da mesma forma, a expectativa nutrida em relação à aceitação desse direito no catálogo de direitos fundamentais não é totalmente atendida. $^{553}$

Giovanni Orlandini observa que "o recebimento da greve na família dos direitos fundamentais introduz então em um ordenamento jurídico um elemento de transformação de um equilíbrio existente subtraído da dinâmica institucional, e deixado nas mãos da autonomia organizativa dos trabalhadores. Como consequiência natural disto, apenas a constituição dos sistemas mais ligados à tradição pluralista tem acolhido um reconhecimento 'seco' do direito de greve, qual direito fundamental. Onde falta tal tradição ou resulta mais fraca, a 'constitucionalização' do Estado social fez menos da greve, recebeu-a com fórmula dura restringindo o seu exercício a reivindicações contratuais (ou profissionais) de categoria". 554

É importante observar ainda que "existe uma situação jurídica básica, idêntica para todo ser humano pelo fato de ser homem. O fato destes direitos não serem reconhecidos por uma autoridade legislativa de um país, não anula sua condição jurídica, posto que mantêm uma previsão de vigência que será efetiva no momento de sua conquista." 555

\footnotetext{
${ }^{552}$ ORGANIZACIÓN INTERNACIONAL DEL TRABAJO. OIT: La libertad sindical. Recopilación de decisiones y principios del Comité de Libertad Sindical del Consejo de Administración de la OIT, cit.

${ }^{553}$ ORLANDINI, Giovanni. op. cit., p. 19.

${ }^{554}$ Id. Ibid., p. 22.

${ }^{555}$ LABRADA RUBIO, Valle. op. cit., p. 22.
} 


\section{CONCLUSÃO}

O direto de greve não é uma folha errante ao sabor da brisa do pensamento daqueles que influenciam ou determinam o estado das coisas em razão do poder que lhes é conferido pelas instituições as quais representam. É um direito pertencente a uma estrutura sustentada por princípios e, por isso, deve ser entendido de uma forma sistêmica. O direito de greve dos servidores públicos como uma espécie particular desse direito não foge a essa regra.

O direito de greve está intimamente relacionado aos direitos de sindicalização e de negociação coletiva e os três devem ser interpretados conforme os princípios do direito coletivo do trabalho, que podem ser resumidos à liberdade sindical e à autonomia privada coletiva.

Os trabalhadores se associam em forma de sindicatos para juntos e organizados poderem defender os seus interesses comuns em contraposição aos seus empregadores, sejam eles entes privados ou públicos. Em meio a sua posição de inferioridade econômica, somente desta forma os trabalhadores têm força para defender seus interesses e para conseguir, por meio da negociação coletiva de trabalho, estabelecer melhores condições de trabalho. A greve neste contexto é um instrumento indispensável para que a negociação resulte satisfatória para os trabalhadores, ou mesmo, para impelir o empregador a sentar-se à mesa de negociação.

Evidentemente que, em relação ao direito de greve dos servidores públicos outros elementos estão agregados, como os princípios do direito administrativo, mormente, o princípio da continuidade do serviço público e o princípio da legalidade. No entanto, eles não impedem o exercício desse direito, pois podem ser tomadas algumas medidas para a satisfação desses princípios sem, contudo, inviabilizar o direito de greve dos servidores públicos. Podem ser feitas algumas adaptações como a exigência de aviso prévio para a deflagração da greve; a manutenção de serviços indispensáveis acordado entre as partes, como ocorre na Itália, e antecipação das negociações para satisfação dos requisitos impostos pela lei orçamentária.

Não podemos aceitar também a negação ao direito de greve dos servidores públicos sob o argumento de tratar-se de serviços essenciais, pois nem todos os serviços públicos 
são essenciais, da mesma forma que existem muitos serviços essenciais prestados pela iniciativa privada.

A greve, além de ser um instrumento de luta de que dispõem os trabalhadores para alcançar melhores condições de trabalho, também é um instrumento de defesa da democracia no ambiente de trabalho, pois dá voz aos trabalhadores para que estes possam participar mais ativamente na relação de trabalho e, possivelmente, influir nela. No serviço público ela também pode servir como instrumento de luta e, principalmente, para salvaguardar a participação dos servidores na administração pública ao possibilitar que estes emitam as suas opiniões a respeito das condições de trabalho, propiciando um ambiente mais democrático nessa relação de trabalho com o ente público.

O direito de greve, enquanto direito econômico e social, é reconhecido como direito humano em diversos instrumentos normativos internacionais de forma implícita, como ocorre na Declaração Universal de Direitos Humanos de 1948, ou de forma explícita como acontece no Pacto Internacional sobre Direitos Econômicos, Sociais e Culturais de 1966, ambos no âmbito da Organização das Nações Unidas, e na Carta Social Européia, firmada em 1961 pelo Conselho da Europa, no âmbito da União Européia. A Organização Internacional do Trabalho também tem considerado o direito de greve um dos direitos humanos do trabalhador.

O reconhecimento do direito de greve como direito fundamental está apoiado no fato de que a greve é um instrumento indispensável para a manutenção social do homem trabalhador, ou seja, ela, de certa forma, garante condições de trabalho condizentes com a dignidade humana, pois é do trabalho que este homem tira o seu sustento e o de seus familiares. O valor dignidade humana a ser defendido pelo direito de greve não depende de quem paga a remuneração devida ao trabalhador - ente privado ou público -, mas tão somente da sua condição humana, sendo, portanto o servidor público também coberto por essa garantia.

Além do mais, não podemos esquecer que os direitos humanos são dotados de universalidade e, por isso, são seus titulares todos os seres humanos. A greve como direito fundamental que é, deve ter a sua titularidade estendida, se não a todos os indivíduos, pelo menos ao maior número deles. No caso de ser negada a algum segmento de trabalhadores, como ocorre com os militares e com servidores que exerçam funções de autoridade em nome do Estado, a eles devem ser fornecidas medidas compensatórias para que possam 
defender os seus interesses, como procedimentos de conciliação e arbitragem adequados, imparciais e céleres.

Os direitos humanos também são dotados de interdependência, de forma que o reconhecimento do direito de sindicalização está interligado ao reconhecimento do direito de greve, uma vez que o conteúdo de cada um deles estão vinculados entre si, pois são complementares um do outro e isso independe de se tratar de trabalhadores do setor privado ou público.

A Constituição de 1988 reconheceu ao servidor público civil o direito de greve e, independentemente de edição da lei específica existe o direito e, como direito fundamental que é, deve ter uma aplicação imediata, como garante o próprio texto constitucional no artigo $5^{\circ}, \S 1^{\circ}$, de modo que pode ser invocado desde logo, mesmo ausente a lei regulamentadora. Além disso, pela indivisibilidade presente entre os direitos humanos não há como proteger apenas alguns direitos humanos reconhecidos, ou seja, desvincular o direito de sindicalização do direito de greve.

No caso dos servidores públicos não resta dúvida que o ordenamento brasileiro o proclama e dá condições para o seu exercício desde logo, mas mesmo que não o fizesse isso não descaracterizaria a sua condição de direito humano. No entanto, é urgente o reconhecimento da negociação coletiva no setor público para que o direito de greve possa ser gozado na sua plenitude. Qualquer lei que vier, futuramente, disciplinar a matéria não poderá restringir ou limitar esse direito de forma a descaracterizá-lo.

Não podemos deixar de mencionar que, o reconhecimento do direito de greve como direito humano fundamental, assim como, este atrelado ao direito de sindicalização e da negociação coletiva entendido como unidade indissociável, confere ao Estado outro patamar, ligado à construção de uma verdadeira democracia social e de respeito ao pluralismo, uma vez que proporciona uma maior participação da classe trabalhadora na definição das suas condições de trabalho, seja ela do setor privado ou do setor público. 


\section{RESUMO}

Esta dissertação tem por objetivo demonstrar que o direito de greve dos servidores públicos é um direito humano fundamental. Antes, no entanto, é preciso investigar o direito de greve e a sua relação com o direito de sindicalização e de negociação coletiva de trabalho, todos em meio ao princípio da liberdade sindical e da autonomia privada coletiva, o que também ocorre caso da greve dos servidores públicos. Posteriormente, será analisada a trajetória da construção dos direitos humanos ao longo da história, bem como, o exercício do direito de greve dos servidores públicos na efetivação dos direitos humanos fundamentais.

Palavras-Chave: Greve, Direito, Humano, Serviço, Público 


\section{RIASSUNTO}

Questa dissertazione ha per finalità confermare che il diritto di sciopero dei addetti ai pubblici servizi è un diritto umano fondamentali. Innanzi, però, ha bisogno di ricercare il diritto di sciopero ed il suo rapporto con il diritto di organizzione sindacale e di fare contrattazione collettiva di lavoro, tutti insieme con il principio della libertà sindacale e della autonomia privata collettiva, anche con il diritto di sciopero dei addetti ai pubblici servizi. Dopo, sarà analizzata la traiettoria di costruzione dei diritti umani nella storia ed il esercizio del diritto di sciopero dei addetti ai pubblici servizi nella effettivazione dei diritti umani fondamentali

Key words: Sciopero, Diritto, Fondamentali, Pubblici, Servizi 


\section{REFERÊNCIAS BIBLIOGRÁFICAS}

ALEXY, Robert. Teoria dos direitos fundamentais. Trad. Virgílio Afonso da Silva. São Paulo: Malheiros Ed., 2006.

ALONSO OLEA, Manuel. Introdução ao direito do trabalho. Trad. C. A. Barata Silva em colaboração com Darci Rodrigues de Oliveira Santana. 4. ed. São Paulo: LTr, 1984.

ANTUNES, Ricardo. A rebeldia do trabalho: o confronto operário do ABC Paulista: as greves de 1978/80. 2. ed. Campinas: Ed. da Uniamp, 1992.

ARAÚJO, Edmir Netto de. Curso de direito administrativo. 2. ed. São Paulo: Saraiva, 2006.

ARISTÓTELES. Política. São Paulo: Nova Cultural, 1999.

BARROS, Alice Monteiro. Curso de direito do trabalho. 2. ed. São Paulo: LTr, 2006.

Curso de direito do trabalho. 4. ed. São Paulo: LTr, 2008.

BARROS, Sergio Resende de. Direitos humanos: paradoxo da civilização, 2001 Tese (Livre docência) - Faculdade de Direito, Universidade de São Paulo, São Paulo, 2001.

BATALHA, Wilson de Souza Campos. Relações coletivas do trabalho: conflitos abertos do trabalho e sua solução. São Paulo: Federação e Centro das Indústrias, 1958.

BOBBIO, Norberto. A era dos direitos. Tradução de Carlos Nelson Coutinho. Rio de Janeiro: Campus, 1992.

Teoria do ordenamento jurídico. Trad. Maria Celeste C. J. Santos. 10. ed. Brasília: Ed. da UnB, 1997.

BONAVIDES, Paulo. Curso de direito constitucional. 12. ed. São Paulo: Malheiros Ed., 2002 .

BRANCO, Paulo Gustavo Gonet; COELHO, Inocêncio Mártires; MENDES, Gilmar Ferreira. Curso de direito constitucional. São Paulo: Saraiva, 2007.

BRIOSCHI, Gian Antonio; SETTI, Federico. Lo sciopero nel diritto: rassegna delle legislazioni dei vari stati. Milano: Giuffrè, 1949.

BRONSTEIN, Arturo S. La negociación colectiva: un análisis comparativo. Educación Obrera, n. 114/115, 1999. La negociación colectiva; um principio fundamental, um derecho, um convenio. 
BRONSTEIN, Arturo S.; CÓRDOVA, Éfren. A negociação coletiva. In: CÓRDOVA, Éfren (Dir.). As relações coletivas de trabalho na América Latina: um estudo de seus autores, suas diversas manifestações e seus conflitos, com especial referência ao setor privado. Tradução de Maria Luiza Jacobson. São Paulo: LTr; IBRART; Genebra: Organização Internacional do Trabalho, 1985.

CALAMANDREI, Piero. Significato costituzionale del diritto del sciopero. In: CAPPELLETTI, Mauro (a cura di). Opere giuridiche. Napoli: Morano,1968. v. 3.

CAVALCANTI, Carlos André Macêdo; SIMÕES, Daniel; PEIXOTO, Edson; COSTA, Moisés. História moderna dos direitos humanos: uma noção em construção. In: TOSI, Giuseppe (Org.). Direitos humanos: história, teoria e prática. João Pessoa: Ed. Universitária, 2005.

CESARINO JUNIOR, A. F. Direito social brasileiro. 2. ed. São Paulo: Martins, 1943. v. 2.

CODE DU TRAVAIL. Legifrance. Disponível em: <http://www.legifrance.gouv.fr/affichCode.do;jsessionid=8413501DAEEDA68595DAB95 01AE2C0DC.tpdjo04v_3?idSectionTA=LEGISCTA000006177988\&cidTexte=LEGITEX T000006072050\&dateTexte $=20081112>$. Acesso em: 12 nov. 2008.

COELHO, Rogério Viola. A relação de trabalho com o Estado: uma abordagem crítica da doutrina administrativa da relação de função pública. São Paulo: LTr, 1994.

COMPARATO, Fábio Konder. A afirmação histórica dos direitos humanos. 2. ed. São Paulo: Saraiva, 2001.

CONSTITUCIÓN ESPAÑOLA. Disponível em: <http://www.senado.es/constitu/index.html>. Acesso em: 11 nov. 2008.

CONSTITUCIÓN DE LA REPUBLICA BOLIVARIANA DE VENEZUELA. Disponível em: <http://www.venezuela-oas.org/Constitucion\%20de\%20Venezuela.htm>. Acesso em: 08 nov. 2008.

CONSTITUCIÓN DA REPÚBLICA ORIENTAL DEL URUGUAY. Disponível em: <http://www.parlamento.gub.uy/constituciones/const004.htm>. Acesso em: 21 jan. 2009.

CONSTITUIÇÃO DA REPÚBLICA FEDERATIVA DO BRASIL DE 1967. Disponível em: <http://www.planalto.gov.br/ccivil_03/constituicao/Constitui\%C3\%A7ao67.htm>. Acesso em 15 jan. 2009.

CONSTITUIÇÃO DA REPÚBLICA FEDERATIVA DO BRASIL DE 1988. Disponível em: <http://www.planalto.gov.br/ccivil_03/Constituicao/Constitui\%C3\%A7ao.htm>. Acesso em: 15 jan. 2009. 
CONSTITUIÇÃO DA REPÚBLICA PORTUGUESA. Disponível em: $<$ http://www.parlamento.pt/Legislacao/Paginas/ConstituicaoRepublicaPortuguesa.aspx\#art 57>. Acesso em: 07 nov. 2008.

CONSTITUIÇÃO DOS ESTADOS UNIDOS DO BRASIL (de 10 de novembro de 1937). Disponível em: <http://www.planalto.gov.br/CCIVIL/Constituicao/Constitui\%C3\%A7ao37.htm>. Acesso em: 14 jan. 2009.

CONSTITUIÇÃO DOS ESTADOS UNIDOS DO BRASIL (de 18 de setembro de 1946). Disponível em: <http://www.planalto.gov.br/ccivil_03/constituicao/Constitui\%C3\%A7ao46.htm>. Acesso em: 14 jan. 2009.

CONSTITUIÇÃO POLÍTICA DA REPÚBLICA DO CHILE. Disponível em: $<$ http://www.senado.cl/prontus_senado/antialone.html?page=http://www.senado.cl/prontus _senado/site/artic/20050516/pags/20050516221649.html>. Acesso em: 11 nov. 2008.

CÓRDOVA, Efrén; MORGADO, Emilio. A greve e o fechamento patronal. As relações coletivas de trabalho na América Latina: um estudo de seus atores, suas diversas manifestações e seus conflitos, com especial referência ao setor privado, publicado sob a direção de Efrén Córdova; trad. Maria Jacobson, São Paulo: LTr ; IBRART; Genebra: Organização Internacional do Trabalho, 1985.

COSTITUZIONE DELLA REPUBBLICA ITALIANA. Disponível em: $<$ http://www.cortecostituzionale.it/istituzione/lacorte/fontinormative/lacostituzione/costituz ione_parte_i.asp>. Acesso em 15 jan. 2009.

CRETELLA JÚNIOR, José. Curso de liberdades públicas. São Paulo: Rio de Janeiro, 1986.

- Natureza jurídica da função pública. 1953. Dissertação (Livre docência) Faculdade de Direito, Universidade de São Paulo, São Paulo, 1953.

DALLARI, Dalmo de Abreu. Direito de greve. In: LOUREIRO, Isabel; DEL-MASSO, Maria Cândida Soares. Tempos de greve na Universidade Pública. Marília: Unesp-MaríliaPublicações; São Paulo: Cultura Acadêmica, 2002.

DE LUCA, Carlos Moreira. A negociação coletiva no serviço público. In: SOARES, José Ronald Cavalcante (Coord.). O servidor público e a Justiça do Trabalho: homenagem ao Ministro Ronaldo José Lopes Leal. São Paulo: LTr, 2005.

DE MASI, Domenico. Desenvolvimento sem trabalho. Trad. Eugênia Deheinzelin, São Paulo: Ed. Esfera, 1999. 
DECLARAÇÃO DE DIREITOS DO BOM POVO DE VIRGÍNIA. Disponível em: <http://www.direitoshumanos.usp.br/counter/Doc_Histo/texto/Povo_Virginia.html>. Acesso em: 10 jan. 2009.

DECLARAÇÃO DE DIREITOS DO HOMEM E DO CIDADÃO. Disponível em: $<$ http://www.direitoshumanos.usp.br/counter/Doc_Histo/texto/Direitos_homem_cidad.htm l>. Acesso em: 10 jan. 2009.

DECLARAÇÃO E PROGRAMA DE AÇÃO DE VIENA. Disponível em: http://www.dhnet.org.br/direitos/anthist/viena/declaracao_viena.htm>. Acesso em: 12 jan. 2009.

DELGADO, Maurício Godinho. Negociação coletiva de trabalho. Revista de Direito do Trabalho, São Paulo, ano 28, n. 107, jul./set. 2002.

. Princípios de direito individual e coletivo do trabalho. São Paulo: LTr, 2001.

DI PIETRO, Maria Sylvia Zanella. Direito administrativo. 13. ed. São Paulo: Atlas, 2001.

DINH, Nguyen Quoc; DAILLER, Patrick; PELLET, Alain. Direito internacional público. Lisboa: Fundação Calouste Gulbenkian, 1999.

DIREITOS DOS TRABALHADORES. Lei n. 7.783, de 28 de junho de 1989. Disponível em:

$<$ http://www.pge.sp.gov.br/centrodeestudos/bibliotecavirtual/dh/volume\%20i/tralei7783.ht m>. Acesso em 18 jan. 2009.

DUNNING, Harold. Orígenes del convênio núm. 87 sobre liberdade sindical y derecho de sindicación. Revista Internacional del Trabajo, Genebra, v. 117, n. 2, p. 167-187, 1998.

EMENDA Constitucional n. 1, de 17 de outubro de 1969. Disponível em: $<$ http://www.planalto.gov.br/CCIVIL/constituicao/Emendas/Emc_anterior1988/emc0169.htm>. Acesso em 15 jan. 2009.

ERMIDA URIARTE, Oscar. A flexibilização da greve. Trad. Edilson Alkmin. São Paulo: LTr, 2000.

FERNANDES, António Monteiro. Direito de greve: notas e comentários à lei nº 65/77, de 26 de agosto. Coimbra: Almedina, 1982.

FERREIRA FILHO, Manoel Gonçalves. Direitos humanos fundamentais. 4. ed. São Paulo: Saraiva, 2000.

FIORAVANTE, Tamira Maira. Sindicato, educação e liberdade. São Paulo: LTr, 2008. 
FRANCE. La Constitution - Préambule de la Constitution de 1946. Legifrance. Disponível em: <http://www.legifrance.gouv.fr/html/constitution/const02.htm>. Acesso em: 12 nov. 2008 .

FRANCO FILHO, Georgenor de Sousa. Liberdade sindical e direito de greve no direito comparado: lineamentos, São Paulo: LTr, 1992.

GALANTINO, Luisa. Dirito sindacale. 4. ed. Torino: G. Giappichelli, 2006.

GEMIGNANI, Tereza Aparecida Asta. Autonomia privada coletiva e intervenção estatal. Revista do Tribunal Regional do Trabalho da $15^{a}$ Região, n. 12, p. 25-42, 2000.

GERNIGON, Bernard; ODERO, Alberto; GUIDO, Horacio. Princípios da OIT sobre o direito de greve. In: GERNIGON, Bernard; ODERO, Alberto; GUIDO, Horacio; ERMIDA URIARTE, Oscar. A greve o direito e a flexibilidade. Oficina Internacional del Trabajo. Secretaria Internacional do Trabalho. Brasília: OIT, 2002.

;______ Princípios de la OIT sobre la huelga. Revista Internacional del Trabajo, Genebra, v. 117, n. 4, 1998 (edición 2000).

; ; ERMIDA URIARTE, Oscar. A greve o direito e a flexibilidade.

Oficina Internacional del Trabajo. Secretaria Internacional do Trabalho. Brasília: OIT, 2002.

GHEZZI, Giorgio; ROMAGNOLI, Umberto. Il diritto sindacale. 3.ed. Bologna: Zanichelli, 1992.

GIGLIO, Wagner D. Brasil: trabajadores del Estado em Iberoamerica. Mario Ackerman (Coord.). Buenos Aires: Ediciones Ciudad Argentina. 1998.

. Solução dos conflitos coletivos: conciliação, mediação, arbitragem, resolução oficial e outros meios. LTr: revista legislação do trabalho, São Paulo, v. 64, n. 3, mar. 2003.

GIUGNI, Gino. Diritto sindacale. 9. ed. Bari: Caduce, 1992.

GOMES, Orlando; GOTTSCHALK, Elson. Curso de direito do trabalho. 4. ed. Rio de Janeiro: Forense, 1995.

GOTTSCHALK, Egon Felix. Greve e lock-out: seus efeitos sobre o contrato individual de trabalho, uma contribuição à doutrina do direito coletivo do trabalho. São Paulo: Max Limonad, 1961.

GUEDES, Cezar. Os trabalhdores no setor público brasileiro: prática sindical, conquistas e armadilhas. Análise do período pós-1978. In: OLIVEIRA, C. A. B. et al. O mundo do trabalho: crise e mudança no final do século. Campinas: Ed. Página Aberta, 1994. 
HODGES-AEBERHARD, Jane; ODERO DE DIOS, Alberto. Los principios del Comité de Libertad Sindical relativos a las huelgas. Revista Internacional del Trabajo, v. 106, n. 4, oct./dic. 1987.

HUBERMAN, Leo. História da riqueza do homem. Trad. Waltensir Dutra. 21. ed.. Rio de Janeiro: Guanabara Koogan, 1986.

LAAT ECHEVERRÍA, Bernardo van der. Conflictos colectivos, huelga y paro patronal. In: ERMIDA URIARTE, Oscar; OJEDA AVILES, Antonio (Coords.). El derecho sindical em America Latina. Montevideo: Fundación de Cultura Universitaria, 1995.

LABRADA RUBIO, Valle. Introduccion a la teoria de los derechos humanos. Fundamento. Historia. Declaracion Universal de 10 de deciembre de 1948. Madrid: Civitas, 1998.

LAFER, Celso. A reconstrução dos direitos humanos: um diálogo com o pensamento de Hannah Arendt. São Paulo: Cia. das Letras, 2001.

LEGGE 12 giugno 1990, n. 146. Disponível em: <http://www.normeinrete.it/cgibin/StampaFrameURN?URL=http://www.italgiure.giustizia.it/nir/1990/lexs_126933.html>. Acesso em 15 jan. 2009.

LEGGE Quadro sul pubblico impiego. Legge 29 marzo 1983 n.93. Disponível em: $<\mathrm{http}: / /$ www.normeinrete.it/cgi-

bin/StampaFrameURN?URL=http://www.italgiure.giustizia.it/nir/1983/lexs_101796.html>. Acesso em 16 jan. 2009.

LEITE, Carlos Henrique Bezerra. A greve do servidor público civil e os direitos humanos. LTr: revista legislação do trabalho, São Paulo, v.65, n.12, dez. 2001.

LÓPEZ-MONÍS DE CAVO, Carlos. O direito de greve: experiências internacionais e doutrina da OIT. São Paulo: LTr, 1986.

LUCAS VERDÚ, Pablo. Los derechos humanos como "religión civil”. In: GRAU, Eros Roberto; GUERRA FILHO, Willis Santiago (Orgs.). Direito constitucional: estudos em homenagem a Paulo Bonavides. São Paulo: Malheiros Ed., 2003.

MAGANO, Octavio Bueno. Direito coletivo do trabalho. 3. ed. São Paulo: LTr, 1993. Política do trabalho. São Paulo: LTr, 2001. v. 4.

MAGNA CARTA $\quad$ - $1215 . \quad$ Disponível em: $<$ http://www.direitoshumanos.usp.br/counter/Doc_Histo/texto/Magna_Carta.html. Acesso em: 10 jan. 2009. 
MANUS, Pedro Paulo Teixeira. Relações de direito coletivo Brasil-Itália. Coord. Yone Frediani, Domingos Sávio Zainaghi. São Paulo: LTr, 2004.

MEDAUAR, Odete. Direito administrativo moderno. 9. ed. São Paulo: Ed. Revista dos Tribunais, 2006.

MEIRELLES, Hely Lopes. Direito administrativo brasileiro. 20. ed. São Paulo: Malheiros Ed., 1995.

MELLO, Celso Antônio Bandeira de. Curso de direito administrativo. 14. ed.São Paulo: Malheiros Ed., 2002.

Regime Constitucional dos servidores da administração direta e indireta. São Paulo: Ed. Revista dos Tribunais, 1990.

MELO, Raimundo Simão de. A greve no direito brasileiro. São Paulo: LTr, 2006.

MENDES, Gilmar Ferreira; COELHO, Inocêncio Mártires; BRANCO, Paulo Augusto Gonet. Curso de direito constitucional. São Paulo: Saraiva, 2007.

MINISTERIO DE TRABAJO Y SEGURIDAD SOCIAL (BOE número 75 de 29/3/1995). Disponível em:

<http://www.boe.es/g/es/bases_datos/doc.php?coleccion=iberlex\&id=1995/07730>. Acesso em: 12 nov. 2008.

MONTOYA MELGAR, Alfredo. Derecho del trabajo. 19. Madrid: Tecnos, 1998.

MORAES, Alexandre de. Direitos humanos fundamentais: teoria geral, comentários aos arts. $1^{\circ}$ a $5^{\circ}$ da Constituição da República Federativa do Brasil, doutrina e jurisprudência. 7.ed. São Paulo: Atlas, 2006.

MORAES, Evaristo. Apontamentos de direito operário. 3. ed. São Paulo: LTr, 1986.

MORAES FILHO, Evaristo. O problema do sindicato único no Brasil: seus fundamentos sociológicos. 2. ed. São Paulo: Alfa-Omega, 1978.

NASCIMENTO, Amauri Mascaro. Comentários à lei de greve. São Paulo: LTr, 1989. Compêndio de direito sindical. 3. ed. São Paulo: LTr, 2003.

O debate sobre negociação coletiva. $L T r$ : revista legislação do trabalho, São Paulo, v. 64, n. 9, set. 2000.

. Direito sindical. São Paulo: Saraiva, 1989.

. Iniciação ao direito do trabalho. 20. ed. São Paulo: LTr, 1993. 
NASCIMENTO, Amauri Mascaro. Teoria geral do direito do trabalho. São Paulo: LTr, 1998.

OLIVEIRA, Olga Maria Boschi Aguiar de. A universalidade do princípio da liberdade sindical. Seqüência, Florianópolis, ano 18, n. 34, jul. 1997.

ORGANIZAÇÃO INTERNACIONAL DO TRABALHO. Convenção n. 87, OIT. Disponível em: <http://www.ilo.org/ilolex/portug/docs/convdisp1.htm>. Acesso em: 15 jan. 2009.

Convenção n. 98, OIT. Disponível em: <http://www.ilo.org/ilolex/portug/docs/convdisp1.htm>. Acesso em 15 jan. 2009.

Convenção n. 151, OIT. Disponível em: <http://www.ilo.org/ilolex/portug/docs/convdisp1.htm>. Acesso em: 15 jan. 2009.

Convenção n. $\quad 154, \quad$ OIT. Disponível em: <http://www.ilo.org/ilolex/spanish/convdisp1.htm>. Acesso em: 15 jan. 2009.

ORGANIZACIÓN INTERNACIONAL DEL TRABAJO. Convenção n. 105, OIT. Disponível em: <http://www.ilo.org/ilolex/portug/docs/convdisp1.htm>. Acesso em: 20 jan. 2009.

OIT: Estudio General, 1994, parágrafo 197. Disponível em: <http://www.ilo.org/ilolex/spanish/surveyq.htm>. Acessso em: 14 jan. 2009.

OIT: La libertad sindical. Recopilación de decisiones y principios del Comité de Libertad Sindical del Consejo de Administración de la OIT. 5.ed. rev. Ginebra: OIT, 2006.

Recomendación n. 92, OIT. Disponível em: <http://www.ilo.org/ilolex/spanish/recdisp1.htm>. Acesso em: 20 jan. 2009.

R 163. Recomendación sobre la negociación colectiva, 1981. Disponível em: <http://www.ilo.org/ilolex/spanish/recdisp1.htm>. Acesso em 15 jan. 2009.

ORLANDINI, Giovanni. Sciopero e servizi pubblici essenziali nel processo d'integrazione europea: uno studio di diritto comparato e comunitario. Torino: G. Giappichelli, 2003.

OZAKI, M. Las relaciones de trabajo em la administración pública: 1. Métodos de determinación de las condiciones de empleo. Revista Internacional del Trabajo, Genebra, v. 106, n. 3, jul./sep. 1987.

PALOMEQUE LÓPEZ, Manuel Carlos; ÁLVAREZ DE LA ROSA, Manuel. Derecho del trabajo. 2. ed. Madrid: Ed Centro de Estudios Ramon Areces, 1994. 
PECES-BARBA, Gregório et al. Curso de derechos fundamentales: teoria general. Madrid: Universidad Carlos II e Boletín Oficial del Estado, 1999.

PERA, Giuseppe. Compendio de diritto del lavoro. 5. ed., Milano: Giuffrè, 2000.

. Diritto del lavoro. 5. ed., Padova: CEDAM, 1996.

PERELMAN, Chaïn. Ética e direito. Trad. Maria Ermantina Galvão. São Paulo: Martins Fontes, 1996.

PÉREZ DEL CASTILLO, Santiago. O direito de greve. Trad. Maria Stella Penteado G. de Abreu. São Paulo: LTr, 1994.

PEREZ LUÑO, Antonio Enrique. Derechos humanos, estado de derecho y constitucion. 8. ed. Madrid: Tecnos, 2003.

Los derechos fundamentales. 7. ed. Madrid: Tecnos, 1998.

PESSOA, Robertônio Santos. Sindicalismo no setor público. São Paulo: LTr, 1995.

PIOVESAN, Flávia. Direitos humanos e o direito constitucional internacional. 4. ed. São Paulo: Max Limonad, 2000.

Direitos humanos e o trabalho. In: FREITAS JÚNIOR, Antonio Rodrigues de (Org.). Direito do trabalho: direitos humanos. Leme, SP: Ed. BH, 2006.

POTOBSKY, Geraldo von. El Convenio num. 87, su impacto y la acción de la OIT. Revista Internacional del Trabajo, Genebra, v. 117, n. 2, p. 217-248, 1998.

As organizações sindicais. In: CÓRDOVA, Éfren (Dir.). As relações coletivas de trabalho na América Latina: um estudo de seus atores, suas diversas manifestações e seus conflitos, com especial referência ao setor privado. Ttradução de Maria Luiza Jacobson. São Paulo: LTr; Genebra: Organização Internacional do Trabalho, 1985.

PRESIDÊNCIA DA REPÚBLICA. Lei n. 8.112, de 11 de dezembro de 1990. Disponível em: <http://www.planalto.gov.br/ccivil_03/LEIS/L8112cons.htm>. Acesso em: 15 jan. 2009.

PROCLAMAÇÃO DE TEERÃ. Disponível em: <http://www.dhnet.org.br/direitos/sip/onu/doc/teera.htm>. Acesso em: 12 jan. 2009.

RAMOS, André de Carvalho. Teoria geral dos direitos humanos na ordem internacional. Rio de Janeiro: Renovar, 2005.

RANGEL, Vicente Marotta. Direito e relações internacionais. 6. ed. São Paulo: Ed. Revista dos Tribunais, 2000. 
REPÚBLICA DE PARAGUAY. Constitución Política de 1992. Disponível em: <http://pdba.georgetown.edu/Constitutions/Paraguay/para1992.html>. Acesso em: 08 nov. 2008.

RIVERO, Jean. Les libertes publiques: le regime des principales libertes. Paris: Press Universitaires de France; Thémis, 1977.

ROMITA, Arion Sayão. Servidor público: sindicalização, negociação coletiva, conflitos coletivos, direito de greve. $L T r$ : revista legislação do trabalho, v. 56, n. 7, p. 789-808, jul 1992.

RUSSOMANO, Mozart Victor. Princípios gerais de direito sindical. 2. ed. Rio de Janeiro: Forense, 2000.

SANTOS, Enoque Ribeiro dos. Direitos humanos na negociação coletiva: teoria e prática jurisprudencial. São Paulo: LTr, 2004.

Fundamentos do direito coletivo do trabalho: nos Estados Unidos da América, na União Européia, no Mercosul e a experiência brasileira. Rio de Janeiro: Lúmen Júris, 2005.

; SILVA, Juliana Araújo Lemos da. Direito de greve do servidor público como norma de eficácia contida. Revista de Direito do Trabalho, São Paulo, v. 30, n. 116, p. 213-231, out./dez. 2004.

SANTOS, Ronaldo Lima dos. Teoria das normas coletivas. São Paulo: LTr, 2007.

SARLET, Ingo Wolfgang. A eficácia dos direitos fundamentais. 9. ed. Porto Alegre: Livr. do Advogado, 2007.

SCOGNAMIGLIO, Renato. Diritto del lavoro. 5. ed. Napoli: Editrice Dott. Eugenio Jovene, 2000.

SILVA, Antônio Álvares da. Os servidores públicos e o direito do trabalho. São Paulo: LTr, 1993.

SILVA, José Afonso da. Aplicabilidade das normas constitucionais. 7. ed. São Paulo: Malheiros Ed., 2007.

Curso de direito constitucional positivo. 28. ed. São Paulo: Malheiros Ed., 2007.

SILVA, Walküre Lopes Ribeiro. Autonomia privada coletiva e o direito do trabalho. Revista de Direito do Trabalho, São Paulo, v. 26, n. 97, p. 27-39, jan./mar. 2000. 
SILVA, Walküre Lopes Ribeiro. Autonomia privada, ordem pública e flexibilização do direito do trabalho. In: MEDEIROS, Antonio Paulo Cachapuz de (Org.). Faculdade de Direito da PUCRS: o ensino jurídico no limiar do novo século. Porto Alegre: Edipucrs, 1997. p. 211-222.

A disciplina jurídica da greve e as constituições republicanas no Brasil. Revista da procuradoria Geral do Estado de São Paulo, São Paulo, n. 39, p. 143-163, jun. 1993.

Limites ao direito de greve no contexto democrático: a experiência da Organização Internacional do Trabalho. In: CONGRESSO BRASILEIRO DE DIREITO COLETIVO E DE DIREITO CONSTITUCIONAL DO TRABALHO, 23-24 nov. 1998. Jornal do Congresso. São Paulo: LTr, 1998.

Liberdade sindical no contexto dos direitos humanos: a experiência da OIT. Revista do Departamento de Direito do Trabalho e da Seguridade Social. Departamento de Direito do Trabalho e da Seguridade Social da Faculdade de Direito da USP, São Paulo, v. 1, n.1, p. 205-222, jan./jun. 2006.

. Repressão penal dos atos anti-sindicais no direito brasileiro e italiano. Boletim do Centro de Estudos da Procuradoria Geral do Estado, Suplemento especial, São Paulo, v. 17, n. 5, p. 10-13, maio 1993.

SÜSSEKIND, Arnaldo. Direito internacional do trabalho. 3. ed. São Paulo: LTr, 2000.

SWEPSTON, Lee. Desarollo de las normas sobre derechos humanos y libertad sindical mediante el control de la OIT. Revista Internacional del Trabajo, Genebra, v. 117, n. 2, p. 189-215, 1998.

TOSI, Giuseppe. História conceitual dos direitos humanos. In: TOSI, Giuseppe (Org.). Direitos humanos: história, teoria e prática. João Pessoa: Ed. Universitária, 2005.

TRINDADE, Antônio Augusto Cançado. Cançado Trindade questiona a tese de "gerações de direitos humanos" de Norberto Bobbio. Disponível em: $<$ http://www.dhnet.org.br/direitos/militantes/cancadotrindade/cancado_bob.htm>. Acesso em: 12 jan. 2009.

O legado da Declaração Universal e o futuro da proteção internacional dos direitos humanos. In: AMARAL JÚNIOR, Alberto do; PERRONE-MOPISÉS, Cláudia (Orgs.). $O$ cinqüentenário da Declaração Universal dos Direitos do Homem. São Paulo: Edusp, 1999.

VIANNA, José de Segadas. Direito coletivo do trabalho. São Paulo: LTr, 1972.

VIDAL NETO, Pedro. O direito de greve: evolução histórica. In: PRADO, Ney (Coord.). Direito sindical brasileiro. São Paulo:LTr, 1998. 